\title{
Rural nonfarm employment and international migration as alternatives to agricultural employment : the case of Kyrgyzstan
}

Citation for published version (APA):

Atamanov, A. (2011). Rural nonfarm employment and international migration as alternatives to agricultural employment : the case of Kyrgyzstan. [Doctoral Thesis, Maastricht University]. Boekenplan. https://doi.org/10.26481/dis.20110908aa

Document status and date:

Published: 01/01/2011

DOI:

10.26481/dis.20110908aa

Document Version:

Publisher's PDF, also known as Version of record

Please check the document version of this publication:

- A submitted manuscript is the version of the article upon submission and before peer-review. There can be important differences between the submitted version and the official published version of record.

People interested in the research are advised to contact the author for the final version of the publication, or visit the DOI to the publisher's website.

- The final author version and the galley proof are versions of the publication after peer review.

- The final published version features the final layout of the paper including the volume, issue and page numbers.

Link to publication

\footnotetext{
General rights rights.

- You may freely distribute the URL identifying the publication in the public portal. please follow below link for the End User Agreement:

www.umlib.nl/taverne-license

Take down policy

If you believe that this document breaches copyright please contact us at:

repository@maastrichtuniversity.nl

providing details and we will investigate your claim.
}

Copyright and moral rights for the publications made accessible in the public portal are retained by the authors and/or other copyright owners and it is a condition of accessing publications that users recognise and abide by the legal requirements associated with these

- Users may download and print one copy of any publication from the public portal for the purpose of private study or research.

- You may not further distribute the material or use it for any profit-making activity or commercial gain

If the publication is distributed under the terms of Article $25 \mathrm{fa}$ of the Dutch Copyright Act, indicated by the "Taverne" license above, 
RURAL NONFARM EMPLOYMENT AND

INTERNATIONAL MIGRATION AS ALTERNATIVES TO

AGRICULTURAL EMPLOYMENT:

THE CASE OF KYRGYZSTAN

Aziz Atamanov 
(C) 2011 Aziz Atamanov.

All rights reserved. No part of this publication may be reproduced, stored on a retrieval system, or transmitted in any form, or by any means, electronic, mechanical, photocopying, recording or otherwise, without the prior permission in writing, from the authors.

ISBN 9789086662111

Cover picture by Michal Wilczynski

Published by Boekenplan, Maastricht, the Netherlands 


\title{
Rural Nonfarm Employment and International Migration
} as Alternatives to Agricultural Employment:

\section{The Case of Kyrgyzstan}

\author{
DISSERTATION
}

to obtain the degree of Doctor at the Maastricht University on the authority of the Rector Magnificus Prof. mr. G. P. M. F. Mols in accordance with the decision of the Board of Deans to be defended in public on Thursday 8 September, 2011, at 10:00 hours.

by

Aziz Atamanov 
Supervisor:

Prof. dr. Adam Szirmai

Co-supervisor:

Dr. Marrit van den Berg, (Wageningen University)

Assessment Committee:

Prof. dr. Pierre Mohnen (chairman)

Dr. Peter Lanjouw (the World Bank)

Dr. Melissa Siegel

Prof. dr. Max Spoor (International Institute of Social Studies) 


\section{AKNOWLEDGMENTS}

First and foremost I would like to express my immense gratitude to my supervisors Marrit van den Berg and Adam Szirmai. Marrit van den Berg supported and helped me at all stages of a PhD marathon. I am very thankful that you agreed to be my supervisor without knowing me. You have been always ready to help and I could never imagine that it would be possible to receive answers to thirty emails during one day. Your thorough comments, suggestions, and constructive critique not only helped to improve the quality of the thesis tremendously, but also helped to develop my skills and knowledge useful for my future research carrier. I also want to thank you for offering me a nice opportunity to spend almost half of a year at Wageningen University taking courses and working over different pieces of my dissertation. That was very helpful to me.

Adam Szirmai played a crucial role in finalization of all articles and the manuscript as a whole. I am very thankful for your careful, constrictive and very professional feedback. You always identified and challenged weak points in the dissertation which helped me to avoid many serious mistakes. Thank you for your moral support as well. This meant a lot to me. It was a pleasure to work with you and to learn from you.

I am very grateful to members of the Reading Committee Prof. dr. Pierre Mohnen, Dr. Peter Lanjouw, Dr. Melissa Siegel, Prof. dr. Max Spoor for reading my dissertation and for useful suggestions and comments which helped to finalise it. I also thank all people who contributed to this thesis through providing useful comments and suggestions during different stages of the manuscript preparation: Dirk Bezemer, Lex Borghans, Denis de Crombrugghe, Thomas Dohmen, Franziska Gassmann, Toman Omar Mahmoud, Joan Muysken, Pawel Kaczmarczyk, Thomas Herzfeld, Chris de Neubourg, Mindel van de Laar, Henry Espinoza Pena, and participants of research tutorials and Joint UNU-MERIT/Maastricht Graduate School of Governance Seminar.

I would also like to thank all people who created and have been running Maastricht Graduate School of Governance. Thank you for giving me a chance to join the School and providing all necessary conditions to finish the dissertation. Each of you helped me to achieve the main goal through different ways.

I am very thankful to my friends and colleagues at the School, especially PPPA cohort 2008-2011: Agnieszka, Alan, Biniam, Derya, Dragisa, Esther, Florian, Jasmin, Judith, Margaret, Mulyadi, Nancy, Nevena, Luis, Innocent, Sachin, Oksana Slobozhan, Oksana Sinyavskaya, and Seda. Thank you for all unforgettable moments we had. I will miss you my friends. I will also remember nice friends and colleagues from other cohorts as well. Special thanks to you Henry, Jessica, Melissa, Treena, Victor for your support and help when I needed. 
Thank you, Sachin for your hospitality and friendship. Your place was a harbour for me and I could rely on you in any circumstances. I will never forget this. I would also like to thank Eveline in de Braek for her help in arranging the defense. I am also thankful to all Dutch people who made me feel like home in the Netherlands. I am especially grateful to Bettine Flesseman, Jacques Janssen, Marian and Izak Bos.

Last, but not least I want to thank my former colleagues at CASEKyrgyzstan who believed in me and with whom I was working for eight years in Bishkek. Roman, Irina L., Irina M., Robert, Julia thank you for everything.

Finally, I want to thank my large family. Without your support and understanding I would never be able to finish. I thank my wife Fatma and my daughter Gulnar who was born when I was defending research proposal and started talking and running when I was finishing the dissertation. You were my little stars showing me the road. 


\section{CONTENTS}

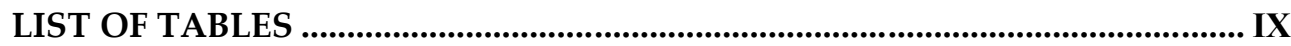

LIST OF FIGURES .................................................................................................. XI

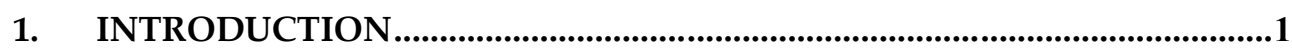

1.1 LOCAL NONFARM ACTIVITIES AND INTERNATIONAL

MIGRATION AS ALTERNATIVES TO WORK IN AGRICULTURE ......................2

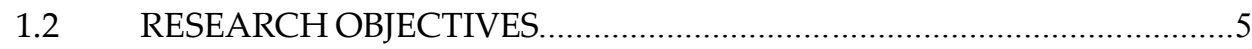

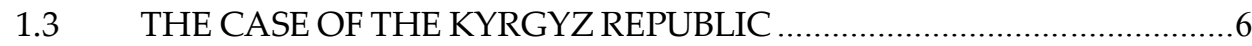

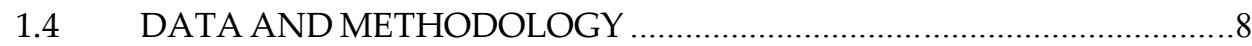

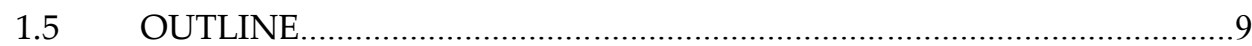

2. THE SOCIO-ECONOMIC DEVELOPMENT OF RURAL AREAS IN THE

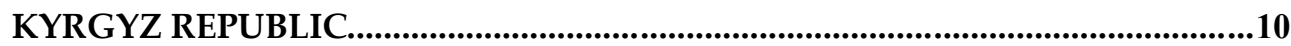

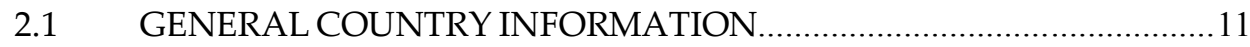

2.2 MACROECONOMIC DEVELOPMENT AFTER INDEPENDENCE ......12

2.3 AGRARIAN REFORMS AND PERFORMANCE OF THE

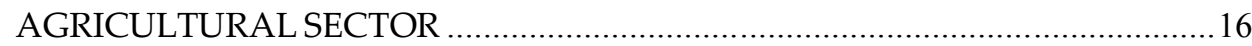

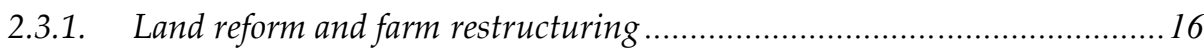

2.3.2. Performance of agricultural sector .......................................................... 18

2.4 DEVELOPMENT OF INSTITUTIONS IN RURAL AREAS:

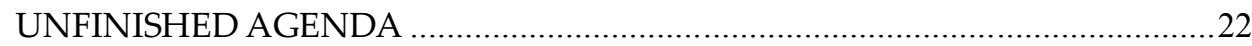

2.5 POTENTIAL IMPACT OF CHANGES IN RURAL AREAS ON THE

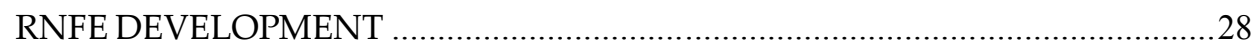

3. RURAL NONFARM ACTIVITIES IN THE KYRGYZ REPUBLIC: A REGIONAL ANALYSIS OF MAGNITUDE, STRUCTURE, EVOLUTION AND

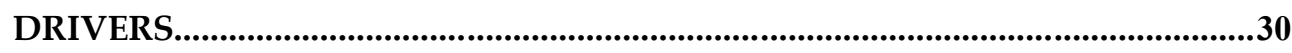

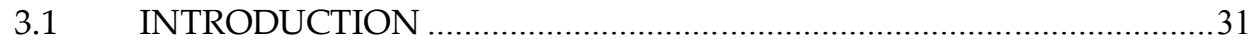

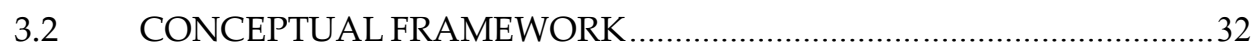

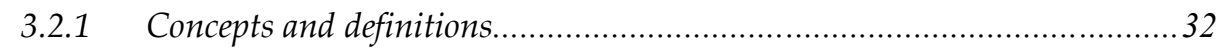

3.2.2 Determinants of nonfarm activities at the regional level .............................33

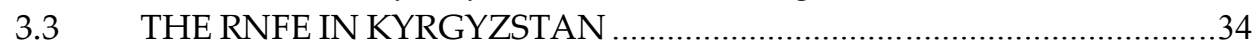

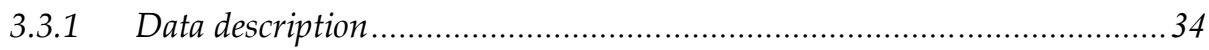

3.3.2 Magnitude, structure and dynamics of the RNFE during 2003, 2005 and $2006 \quad 36$

3.4 RNFE DETERMINANTS AT THE RAYON LEVEL ....................................

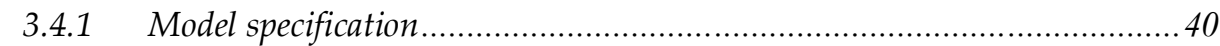

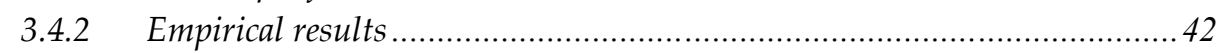

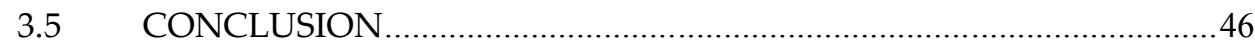

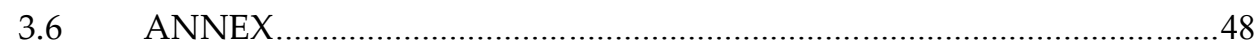


4. MICROECONOMIC ANALYSIS OF RURAL NONFARM ACTIVITIES IN KYRGYZSTAN: WHAT DETERMINES PARTICIPATION AND RETURNS? ..49

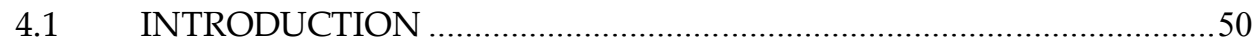

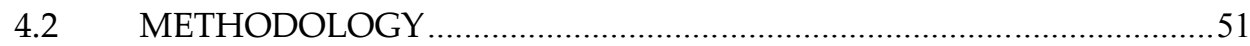

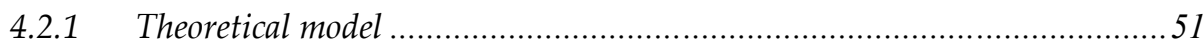

4.2.2 Data description and proposed estimation techniques and specifications....52

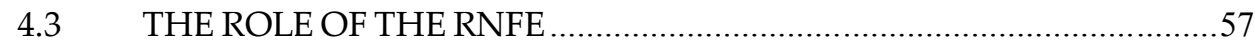

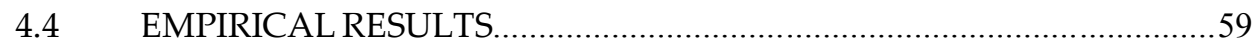

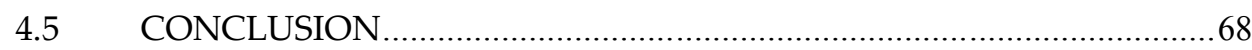

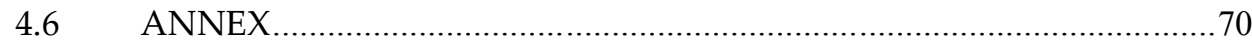

5. THE CHOICE BETWEEN INTERNATIONAL MIGRATION AND LOCAL RURAL ACTIVITIES IN THE KYRGYZ REPUBLIC ..........................................84

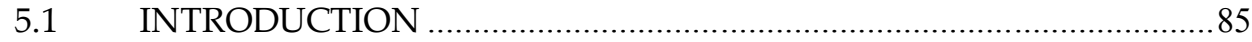

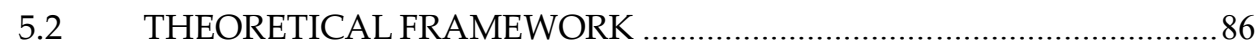

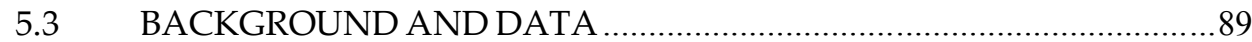

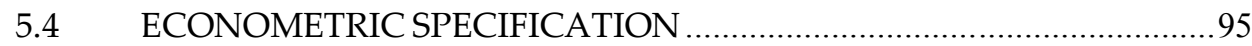

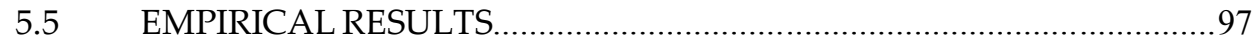

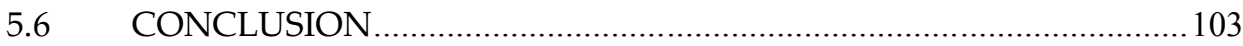

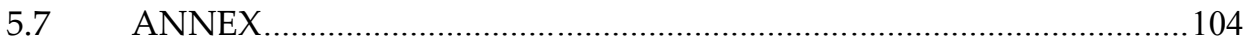

6. INTERNATIONAL MIGRATION, REMITTANCES AND CROP INCOME: EVIDENCE FROM THE KYRGYZ REPUBLIC...............................................107

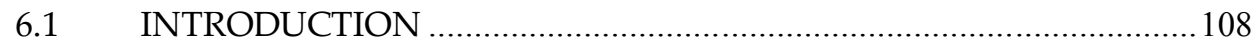

6.2 THEORETICAL FRAMEWORK ………...................................................... 109

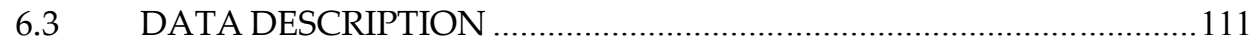

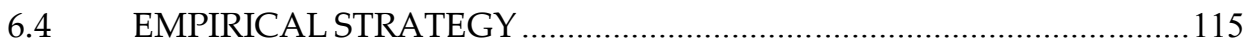

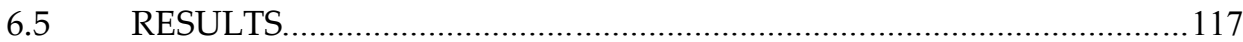

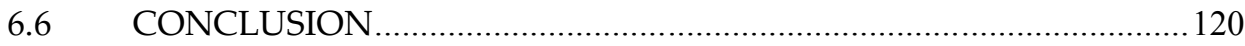

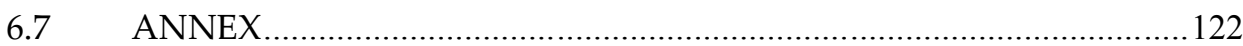

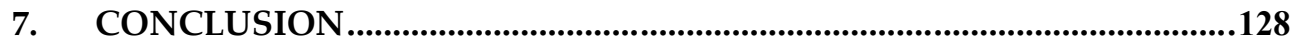

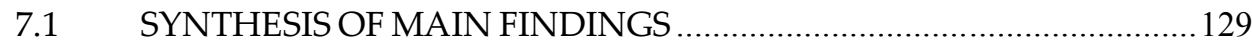

7.2 POLICY RECOMMENDATIONS AND FUTURE STEPS ......................131

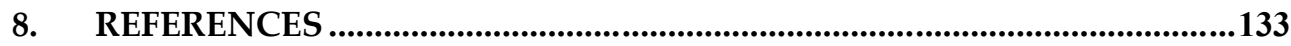

SUMMARY IN DUTCH/SAMENVATTING....................................................143

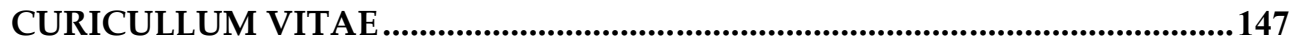

MGSOG DISSERTATION SERIES ............................................................................148 


\section{LIST OF TABLES}

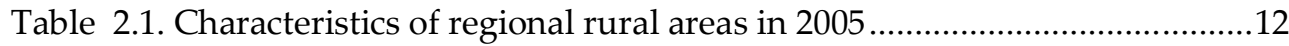

Table 2.2. Selected macroeconomic indicators ..........................................................14

Table 2.3. Main characteristics of farm types in Kyrgyzstan, 2009...........................18

Table 2.4. Selected doing business indicators for Kyrgyzstan, Kazakhstan,

Uzbekistan, and Tajikistan, 2006 ..............................................................................24

Table 2.5. Characteristics of the credit portfolio of commercial banks and nonbank

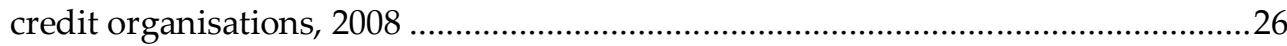

Table 3.2. The number of rural observations and the number of rayons by regions in $2003,2005,2006$ used in the analysis ....................................................................

Table 3.3. Share of rural people employed in nonfarm activities and share of time in nonfarm activities in rural areas, \%

Table 3.4. Mean weakly hours of workload in rural farm and nonfarm sectors, primary and secondary occupations

Table 3.5. Regional structure of rural nonfarm income by functional classification of income in 2005 and 2006, \%

Table 3.6. Descriptive statistics, 2003, 2005 and 2006 years

Table 3.7. OLS regressions of the share of time in nonfarm employment (pooled sample for 2003, 2005 and 2006, $N=119$ ).

Table A3.1. OLS regressions of the share of primary nonfarm employment in total employment at rayon level (pooled sample for 2003, 2005 and 2006, $\mathrm{N}=119$ ).........48

Table 4.1. Share of nonfarm employment to total rural employment and share of time worked in nonfarm activities to total hours worked in rural areas, \%.

Table 4.2. Mean nonfarm income shares, nonfarm and farm income per capita across quintiles based on total income per capita, som

Table 4.3. Relative risk ratios for participation in nonfarm activities in 2005 based on multinomial logit.

Table 4.4. Marginal effects of the probit model for primary participation in rural nonfarm activities in 2005 at the mean of explanatory variables

Table 4.5. Double hurdle model, marginal effects after probit and results after truncated regression for logarithm of income from rural nonfarm activities, 2005 year

Table A4.1. Descriptive statistics, 2005-2006...........................................................70

Table A4.2. Relative risk ratios for participation in nonfarm activities based on multinomial logit, 2006

Table A4.3. Marginal effects of the probit model for primary participation in rural nonfarm activities at the mean of explanatory variables, 2006.

Table A4.4. Double hurdle model, marginal effects after probit and results after truncated regression for logarithm of income from rural nonfarm activities, 2006.75 
Table A4.5. Relative risk ratios for participation in nonfarm activities based on multinomial logit, without potentially endogenous variables, 2005

Table A4.6. Truncated regression for logarithm of rural nonfarm self-employment income without potentially endogenous variables, 2005 year

Table A4.7. Results from the multivariate probit model for primary participation in rural nonfarm activities, 2005

Table A4.8. Results from Hausman tests of IIA assumption, 2005 (N=12069).........83

Table A4.9. Results from Small-Hsiao tests of IIA assumption, 2005 (N=12069).....83

Table A4.10. Results from Hausman tests of IIA assumption, 2006 ( $\mathrm{N}=13408) \ldots . . . .83$

Table A4.11. Results from Small-Hsiao tests of IIA assumption, 2006 ( $\mathrm{N}=13408) . . .83$

Table 5.1. Individual characteristics across occupations and test for the equality of means for migrants/non-migrants and seasonal/permanent migrants, 2006 ...........92 Table 5.2. Test for the equality of means for different characteristics of households with and without migrants, households with seasonal and permanent migrants, 2006.

Table 5.3. Average household rural income from remittances and local income generating activities in 2006, som.

Table 5.4. Relative risk ratios from multinomial logit, individuals of working age in rural areas, employment in agriculture is the base outcome, 2006 . 100

Table 5.5. Occupational status among rural individuals of working age by migration status, \%.

Table A5.1. Results from Hausman tests of IIA assumption ( $\mathrm{N}=6171) \ldots \ldots \ldots \ldots \ldots \ldots . . .104$

Table A5.2. Results from Small-Hsiao tests of IIA assumption ( $\mathrm{N}=6171)$...............105

Table A5.3. Results from multinomial probit, individuals of working age in rural areas, employment in agriculture is the base outcome, 2006 105 Table 6.1. Distribution of households with migrants across land per capita quartiles in $2006, \%$

Table 6.2. Income shares, total income per capita and the use of credit resources across land per capita quartiles, 2006.

Table 6.3. Total crop income for households with and without migrants across land per capita quartiles, $2006(\mathrm{~N}=1836)$

Table 6.4. Mean values for inputs, land productivity and income for households with and without remittances across land per capita quartiles, 2006 ...... .114

Table 6.5. Occupational status among rural individuals of working age by migration status, \%.

Table 6.6. Regression results for crop income in 2006, three specifications based on recursive system of equations and IV regressions $(\mathrm{N}=1836)$...

Table A6.1. First stage equations from the recursive system of OLS equations for first and second specifications $(\mathrm{N}=1836)$.

Table A6.2. First stage equations from the recursive system of OLS equations for third specification $(\mathrm{N}=1836)$. 
Table A6.4. Description of variables

Table A6.5. Results from recursive system of OLS equations for total earned income, first specification $(\mathrm{N}=1836)$

\section{LIST OF FIGURES}

Figure 2.1. Real growth rates of GDP in agriculture, industry and services, 19912008.

Figure 2.2. Mean contribution of different sectors to the total real growth rates of GDP, \%

Figure 2.3. Shares of crops and livestock in gross agricultural output (GAO) and rates of growth.

Figure 2.4. Land and labour agricultural productivity during 1991-2009 years, thousand som .20

Figure 2.5. The structure of gross agricultural output across farm types.................21

Figure 2.6. Land productivity across farm types, 2009 …….................................22

Figure 2.7. Transition indicators in Central Asian countries, 2008...........................23

Figure 2.8. Governance indicators for Kyrgyzstan in 1996 and 2007, percentile rank

Figure 3.1. Mean shares of nonfarm income in total income in rural areas, $\%$ .38 Figure 3.2. Simulation of the change in share of time worked in commercial nonfarm employment to total worked time after increase of total land for different levels of quality, \% . .46 Figure 5.1. Educational categories in occupational choices in 2006, rural areas \% ..93 
1. INTRODUCTION 


\subsection{LOCAL NONFARM ACTIVITIES AND INTERNATIONAL MIGRATION AS ALTERNATIVES TO WORK IN AGRICULTURE}

It is widely acknowledged that agriculture alone is not sufficient to achieve sustainable poverty reduction in developing countries and that the rural nonfarm economy (RNFE) is an indispensable part of development in rural areas (World Bank, 2008). The RNFE covers a heterogeneous array of local ${ }^{1}$ non-agricultural activities ranging from activities that are highly connected with agriculture, such as the agro-processing industry, to skill-intensive education and health services. According to Haggblade et al. (2007), local nonfarm activities generate about $30 \%$ to $50 \%$ of rural income worldwide. They expand rapidly and contribute to economic growth in rural areas.

Rural inhabitants participate in the RNFE because of "pull" or "push" factors or combination of both. "Pull" factors are related to higher pay-offs relative to agriculture. They are relevant in areas with a strong agricultural base or other local growth motors such as resort areas or mines. In these areas, growing agriculture requires inputs and services from nonfarm firms, while higher agricultural income enables rural households to increase expenditure on nonfarm products and services. Growing demand encourages rural nonfarm producers to expand their activities, while higher real income changes the structure of nonfarm activities from low-returns labour intensive into more remunerative ones (Haggblade et al., 2002; Reardon et al., 2006).

In contrast to "pull" factors, "push" factors are more complex and related to risk management (both ex post and ex ante), diminishing or varying returns to labour or land, and incomplete credit and insurance markets. Firstly, risky farming can stimulate rural households to undertake nonfarm activities which are not strongly correlated with agriculture and act as an ex ante risk mitigation strategy, while harvest fails or loss of cattle can induce households to reallocate family labour to non-agricultural activities to cope with shocks ex post (Ellis, 1998). The role of nonfarm activities as a risk management is very important in developing countries where credit and insurance markets are incomplete. Secondly, participation in nonfarm activities can evolve naturally in areas with poor agricultural conditions when farm output is not sufficient for survival due to the high population pressure on land, land degradation, and poor climatic conditions.

\footnotetext{
${ }^{1}$ In this study we distinguish between local nonfarm activities and international migration as two different alternatives to working in agriculture with different determinants and effects on local development. Therefore, here and afterwards the RNFE includes only local nonfarm activities. Internal migration can be also an important alternative to work in the agricultural sector, but is not considered in this dissertation because of the lack of data. Detailed description of the conceptual framework used in this dissertation is presented in section 3.2.1.
} 
Thirdly, income from nonfarm activities can be crucial to finance agricultural inputs in case credit markets are imperfect or land can not be used as collateral due to land market imperfections (Barrett et al., 2001). Knowing which scenario "pull" or "push" is at work behind the RNFE will help to understand the prospects of nonfarm activities and to design appropriate policies to increase its developmental effects.

Taking into account the described potential of rural nonfarm activities to overcome seasonal income variability of agricultural activities, to finance purchases of agricultural inputs and to provide income in case of droughts and the loss of livestock, participation in the RNFE is expected to be particularly beneficial for those who are more vulnerable to risk and seasonality (Ellis, 1998; Barrett et al., 2001). However, empirical studies often demonstrate that those in need for nonfarm activities, such as the landless and households with small land holdings, are often excluded from these activities due to lack of education, access to capital, infrastructure, and social contacts (see review for Africa in Reardon, 1997 or crosscountry comparison in Davis, 2010). Therefore, in order to develop efficient policies to alleviate rural poverty, policymakers need an insight in factors shaping the capacity of rural residents to participate in nonfarm activities.

Exploring determinants of participation in the RNFE is complicated by heterogeneity of nonfarm activities which may have different entry barriers and as a result different determinants (Shi et al., 2007). Moreover, since participation and nonfarm income are not necessarily based on the same process their determinants may have different effects at each stage (see Matshe \& Young, 2004). For example, households with a lot of land may have weak incentives to engage in the RNFE, but given participation they may earn larger nonfarm income than the landless who do not have enough cash resources to access profitable activities. Separate modelling of participation and income from nonfarm activities has been rarely done in empirical studies. It can contribute to a better understanding of the two processes.

Besides local nonfarm activities, international labour migration is another income generating strategy in the context of a poor agricultural base, risky and seasonal agriculture, and imperfect markets in developing countries. It is not necessarily an easily accessible option for everyone due to substantial costs and it often attracts better educated individuals from the middle of the income distribution. This could have a negative impact on local agricultural and nonfarm activities due to the brain drain effect when migration attracts the most productive members of the household. Therefore, identifying motivations and barriers to international migration is crucial for understanding which rural households bear the costs or potential benefits from this process, which policies should be implemented to strengthen its developmental impact and how this income strategy interacts with local alternatives to agricultural employment (Taylor \& Martin, 2001; Mora \& Taylor, 2005). 
According to the New Economics of Labour Migration (NELM), migration may have negative and positive impacts on local income generating activities through lost labour and obtained remittances in incomplete market environment (Taylor, Rozelle \& de Brauw, 2003; de Brauw, 2010). This is different from the predictions of separable household models where migration is not expected to affect investment and production decisions in perfect market environment (Singh, Squire \& Strauss, 1986; Wouterse \& Taylor, 2008).

The positive impact of remittances in the NELM should not be necessarily homogeneous across households since they may encounter different constraints and the lost labour effect is not likely to be the same for seasonal and permanent migration because the former implies regular returns home (Taylor \& Wyatt, 1996). Testing these hypotheses has received limited attention in empirical studies. They were mostly focused on poverty and inequality effects of migration and remittances (Lokshin \& Glinskaya, 2008).

Three out of five Central Asian republics (Kyrgyzstan, Uzbekistan and Tajikistan) represent countries with the highest share of rural population $(67 \%$ on average) and the highest share of agriculture in the national economies $(30 \%$ on average) in the former Soviet Union in 2007 (FAO, 2009). In spite of economic growth and various reforms, poverty is still rampant and mostly concentrated in rural areas of the region. Throughout the region there is a need for policies to respond to this challenge and there is an increasing acknowledgment among policy makers and the donor community that agricultural development alone is not sufficient to achieve sustainable poverty reduction in the context of high population pressure, constrained land resources, and unfinished agricultural reforms (World Bank, 2004; Maddock, 2009).

International labour migration has been a widely used regional income diversification strategy (Mansoor \& Quillin, 2006; ADB, 2008abc; International Labour Organization, 2010), but the current economic crisis makes its prospect uncertain. In such circumstances, the rural nonfarm economy may act as a cushion, absorbing rural labour and providing an opportunity to earn money. Several studies have analysed the nature and consequences of agricultural reforms in postsoviet Central Asia (for example, Rozelle \& Swinnen, 2004; Lerman, 2007), but there is almost complete lack of empirical evidence on the development of the rural nonfarm economy, its drivers and interrelationships with international labour migration in this region.

Reviewing the literature demonstrates the importance of understanding the factors shaping development, access to the RNFE and the size of nonfarm income in rural areas of poor countries. Little is known about the RNFE in postsoviet Central Asia, where agriculture can hardly sustain the pressure of abundant labour force on limited land resources. Moreover, there is scarce empirical evidence on the determinants of another alternative to agriculture - international migration - distinguishing between seasonal and permanent moves and exploring 
their interrelationships with local income generating activities. ${ }^{2}$ Finally, those few studies on the impact of migration and remittances on local income sources often ignore heterogeneity across rural households and the types of migration which can lead to misleading results and inhibit developing of more targeted policy measures.

\subsection{RESEARCH OBJECTIVES}

Taking into account indentified gaps in nonfarm and migration literature, the main goal of this dissertation is to increase our understanding of the role, determinants and effects of local rural nonfarm activities and international labour migration as two important non-agricultural income strategies. The following objectives are addressed to achieve the main goal:

1. To explore the nature, structure and evolution of the RNFE at the regional level in the context of a poor transition country from Central Asia. To examine which factors explain the magnitude of the RNFE at the aggregate level.

2. To identify determinants of participation and income across different nonfarm activities at the micro level in the context of poor transition country from Central Asia. To compare effects of the identified determinants on the decision to participate in nonfarm activities and nonfarm income.

3. To determine and compare factors affecting the choice between international permanent, seasonal migration and local nonfarm activities of rural individuals.

4. To test the NELM propositions about effects of international labour migration and remittances on agricultural productivity and crop income. To check whether the effect of remittances is different for farmers with different land size and whether lost labour effect is different for seasonal and permanent migration.

Analysis of the RNFE at the aggregate level can be relevant both for the nonfarm literature and for Central Asian policy makers. This study will present new empirical evidence on the development, structure and determinants of nonfarm activities at the macro and meso levels in a poor transition country after the decade of reforms.

Identification of factors which help or constrain rural residents to participate in the RNFE and earn nonfarm income at the micro level is a logical continuation of the first research objective. A methodological novelty of the second

\footnotetext{
${ }^{2}$ By permanent migration we mean non-seasonal long-term migration which does not involve repeated moves during particular seasons and can result in permanent stay of migrants abroad.
} 
objective is a separate modelling of participation and income from nonfarm activities since it has been rarely done in empirical studies (the exception is Matshe \& Young, 2004). This can help policy makers to take more informed decisions when designing policies and strengthening institutions targeted to enable poor rural households to participate in the RNFE and to move towards more remunerative nonfarm activities and avoid poverty traps.

Combining international seasonal, permanent migration and local nonfarm activities in a single empirical model allows us to compare their determinants and better understand their complex interrelationships. Both income strategies may compete and constrain each other attracting the most productive members of rural households because education is often mentioned as an important determinant of migration and local nonfarm activities (Taylor \& Martin, 2001; Haggblade, 2007). Since education seems to be more important for permanent migrants, who tend to be longer abroad and manage to get formal long-term employment, seasonal migration may not have brain drain effects on local farm and nonfarm activities (Newland, 2009). This makes the third research objective an interesting task with a contribution to the brain drain discussion and enriching migration and nonfarm literature.

The last research objective expands existing studies about the impact of migration and remittances on crop income and agricultural productivity (Lucas, 1987; Taylor \& Wyatt, 1996; Taylor et al., 2003; de Brauw, 2010). It has important policy implications indicating which farmers benefit from remittances and indirectly informing the policy makers about the distribution of constraints and the impact of market failures on households with different land size. The obtained results can contribute to the ongoing debate about the less negative effects of seasonal migration when productive labour is not lost for the home country (Görlich \& Trebesch, 2008). The results can be interesting for the discussion of measures required to increase the farmers' productivity after land reforms in Central Asia (see, for example Lerman, 2007; Lerman \& Sedik, 2009a). Finally, addressing this objective can inform policy makers on the potential of migration to stimulate or depress agriculture and indirectly affect local nonfarm activities.

\subsection{THE CASE OF THE KYRGYZ REPUBLIC}

To address the described research objectives we use the case of post-soviet Kyrgyz Republic. $^{3}$ Kyrgyzstan is a very interesting case to explore. It is a poor, predominantly rural transition country with $65 \%$ of the population residing in rural areas and with agriculture generating $27 \%$ of Gross Domestic Product (GDP) in 2009. Following the break-up of the USSR, both industrial and agricultural

\footnotetext{
${ }^{3}$ Kyrgyzstan and the Kyrgyz Republic are both official names of the same country and used in the text interchangeably.
} 
production collapsed, existing organizations were broken down, and new economic structures had to be developed.

In order to respond to these challenges, the Kyrgyz Government launched a broad program of stabilization and structural reforms with strong support of the international donor community. As a result of the reforms the economy started growing after 1995. The driving force of the economic growth was the agricultural sector, which grew rapidly after the main phase of farm restructuring and land reform in the years 1995-1996. Decision-making power and resources of state collective farms were transferred to private family farmers, who became the most important and productive producers in the agricultural sector (Akramov \& Omuraliev, 2009).

The shift to individual farming was one of the main factors responsible for the resumption of agricultural growth after 1995. However, after 2001 growth slowed down and almost vanished. Intensive farming and a switch to high-value crops were not able to sustain the growth rates. The individualization of agricultural producers paradoxically changed from being a driving force of economic growth into a constraining factor because there was no institutional environment in place to serve large numbers of small farmers. Small farmers had difficulties in accessing machinery, seeds, fertilisers (too expensive, lack of cash before agricultural season) and credit resources (lack of collateral, high transaction costs), and in selling their products (small quantities for buyers and too high transportation costs) (Lerman \& Sedik, 2009b). This inhibited a smooth transition of the agricultural sector from a subsistence to a commercial orientation.

The current level of agricultural development is not enough to improve sufficiently the situation in rural areas and farming underemployment and poverty are still on the agenda of rural policy makers (World Bank, 2007). Poor economic conditions, demographic pressure, and unemployment combined with higher wages and demand for labour in oil rich the Russian Federation and Kazakhstan, stimulated international labour migration. ${ }^{4}$ The estimates of the numbers of international labour migrants varied between 200 thousand and 500 thousand from about 5.2 million of total population in 2005-2007. Statistics from the National Bank of the Kyrgyz Republic show an exponential growth in the share of net remittances from workers in GDP from 5.6\% in 2003 to $27.1 \%$ in 2008 . The only representative study of labour migration and remittances showed 251,000 migrants in 2006 with an aggregate inflow of cash remittances in the range of 214.1-276.3 $\mathrm{mln}$. USD (ADB, 2008b).

Expanding international labour migration is an important alternative to working in stagnating agriculture, but it is not the most sustainable income

\footnotetext{
${ }^{4}$ It has different nature from the emigration of Russians and Europeans after the break-up of the Soviet Union. Detailed review of past and present patterns of migration is presented in Schmidt \& Sagynbekova (2008).
} 
strategy, especially in the light of the current crisis. Moreover, is not clear who have access to this costly strategy and how migration affects agricultural activities. In such circumstances, the rural non-farm economy may substitute or complement stagnating agriculture providing rural inhabitants with an opportunity to earn money. This makes Kyrgyzstan an interesting laboratory to explore the structure, developments and determinants of nonfarm activities and their role in the rural economy.

\subsection{DATA AND METHODOLOGY}

In order to achieve our research objectives we employ rural sub-samples from four databases containing cross-sectional data from two different sources. For the analysis of the RNFE at the aggregate level, as proposed in the first research objective, we use three representative household budget surveys conducted by the National Statistical Committee of the Kyrgyz Republic in 2003, 2005 and 2006. ${ }^{5}$ We construct different indicators at country and regional levels to show the magnitude, composition and evolution of nonfarm sector in total employment, income and working time of rural population. The development of the RNFE is discussed in the context of agricultural reforms and changes in the institutional framework.

Regression analysis is used to explain the magnitude of the RNFE measured as percentage of time in commercial nonfarm activities to total time worked at the rayon level. Following the theoretical framework of Reardon et al. (2006), we will model the magnitude of the RNFE as a function of variables potentially affecting incentives and the capacity of rural population to engage in the RNFE and, as a result, shaping the magnitude of commercial nonfarm activities at the rayon level. Afterwards, the obtained coefficients are used to simulate the joint impact of land size and quality on the magnitude of RNFE at the rayon level.

For the micro analysis of individual participation in different nonfarm activities and determinants of nonfarm income in the context of the second research objective we use the same databases for the years 2005 and 2006. In order to identify specific requirements with regards to particular nonfarm sub-categories, we will model participation in rural nonfarm activities, distinguishing between self-employment, private, and public wage employment. We complement the analysis of participation in nonfarm activities with income regressions using double hurdle models to allow explanatory variables to have different impact at each stage.

\footnotetext{
${ }^{5}$ We are very thankful to Mr. Chuikov and Mrs. Praslova from the National Statistical Committee for making the data of the household budget surveys (HBS) of the Kyrgyz Republic available for this research.
} 
To achieve the third research objective we use a rural subsample from the representative household budget survey ${ }^{6}$ conducted by the Asian Development Bank in 2007 to explore determinants of migration and compare them across local income generating activities in Kyrgyzstan. Finally, for the fourth research objective the same database is used to test the NELM propositions about the positive effect of remittances and negative impact of migration on the crop income of rural farmers. We extend the approach by Taylor et al. (2003) by controlling for heterogeneous effects of remittances depending on the farm's land size and including separate lost labour effects for permanent and seasonal migrants. The model is estimated using the system of equations and instrumental variables regression.

\subsection{OUTLINE}

In addition to the introduction (chapter 1) and conclusion (chapter 7), the dissertation consists of five chapters. Chapters 3 to 6 address specific research objectives and represent self-contained articles with their own introductions, literature reviews, theoretical frameworks and conclusions. The second chapter presents the socio-economic development of the country since independence and discusses how it may affect development of the RNFE in Kyrgyzstan. It should be used as background information for each of the subsequent chapters. The focus on local and international income alternatives to work in agriculture in the rural areas of the Kyrgyz Republic is the bridge connecting all the chapters.

The third chapter is devoted to the regional analysis of magnitude, structure, evolution and drivers of the RNFE in Kyrgyzstan. The fourth chapter continues the analysis of rural nonfarm activities started in the third chapter focusing on determinants of participation and nonfarm income at the individual level. In the fifth chapter the focus shifts from local nonfarm activities towards determinants of seasonal and permanent international labour migration as another widely used alternative to work in agricultural activities. In the sixth chapter we test the NELM propositions about the impact of migration and remittances on local crop income distinguishing between farmers with different land size and different types of migration. The conclusions and their interrelationships with each other are summarised in the last chapter. This chapter also includes a discussion of policy implications and a potential agenda for the future research.

\footnotetext{
${ }^{6}$ This survey was specially designed to capture and provide the representative picture on the magnitude of international labour migration in Kyrgyzstan which is not adequately reflected in household budget surveys from the National Statistical Committee of the Kyrgyz Republic.
} 
2. THE SOCIO-ECONOMIC DEVELOPMENT OF RURAL AREAS IN THE KYRGYZ REPUBLIC 


\subsection{GENERAL COUNTRY INFORMATION}

Kyrgyzstan is a former Soviet Union Republic located in Central Asia and bordering on Uzbekistan, Tajikistan, Kazakhstan and China. It is a small landlocked country with a predominantly rural population of around $5.2 \mathrm{mln}$. people with $65 \%$ living in rural areas. Kyrgyzstan is a low-income country with a Gross National Income per capita in 2007 of 590 USD (World Bank, 2008).

The territory of Kyrgyzstan is $199,950 \mathrm{~km}^{2}$ with $90 \%$ of the country's territory covered by mountains. The Tyan Shan Mountains separate the densely populated and climatically warmer south from the more sparsely populated and richer north. Arable land accounts for less than $10 \%$ of total land area. Highly productive agriculture is only possible on irrigated land, which comprises two thirds of arable land. The climate is continental, with temperatures rising to $40^{\circ} \mathrm{C}$ in the summer and falling to $-20^{\circ} \mathrm{C}$ in the winter. The main natural resources are water, used for electricity production, and gold. Most of the country has unfavourable conditions associated with low rainfall, irrigation-dependent farming, problems with soils and a poor domestic transport network (Christensen \& Pomfret, 2007).

The country is divided into 7 regions - Chui, Issykkul, Naryn, Talas, Jalalabat, Batken and Osh- and two cities with the same status: the capital Bishkek located in Chui region and Osh city. Each region comprises rayons (districts), which are administrative areas including cities, urban-type communities and villages. There are 40 rayons in total in the Republic. The size of rayons differs substantially across the regions (from 100 thousand people in the South to 12 thousand in the North).

Regional differences in farm size, landscape and climatic conditions are substantial (see table 2.1). The largest per capita landholdings are in the northern part of the Republic (Chui, Issykkul, Naryn and Talas regions); while in the south (Osh, Batken and Jalalabat regions) agricultural land per capita is much smaller due to higher population pressure. Poverty is also higher in the Southern regions, where population pressure and constrained land resources do not allow agriculture to absorb the rural labour force. Chui region in the North contains a third of the country's arable land, the highest share of educated people, benefits from the location of Bishkek and proximity to Almaty, the capital of Kazakhstan. 
Table 2.1. Characteristics of regional rural areas in 2005

\begin{tabular}{lccccc}
\hline & $\begin{array}{c}\text { Size of } \\
\text { rural } \\
\text { populatio } \\
\mathrm{n} \text {, } \\
\text { thousand }\end{array}$ & $\begin{array}{c}\text { Land } \\
\text { per } \\
\text { capita }\end{array}$ & $\begin{array}{c}\text { Poverty } \\
\text { in rural } \\
\text { areas }^{\mathrm{a}}\end{array}$ & $\begin{array}{c}\text { Share of } \\
\text { individuals with } \\
\text { higher and } \\
\text { vocational } \\
\text { education in total } \\
\text { rural population }\end{array}$ & $\begin{array}{c}\text { Agricultural } \\
\text { output per capita } \\
\text { of rural } \\
\text { population, } \\
\text { thousand som }\end{array}$ \\
\hline Issykkul & 304.9 & 0.46 & $50 \%$ & $26 \%$ & 26.62 \\
Jalalabat & 720 & 0.22 & $58 \%$ & $26 \%$ & 13.43 \\
Naryn & 217.4 & 0.56 & $50 \%$ & $24 \%$ & 22.79 \\
Batken & 304.8 & 0.23 & $51 \%$ & $25 \%$ & 13.53 \\
Osh & 941.6 & 0.21 & $57 \%$ & $25 \%$ & 13.72 \\
Talas & 176.6 & 0.46 & $40 \%$ & $28 \%$ & 33.59 \\
Chui & 598.7 & 0.85 & $21 \%$ & $36 \%$ & 28.52 \\
\hline
\end{tabular}

Source: National Statistical Committee (www.stat.kg) and USAID (2008).

Notes: a poverty data are for 2006 year. ${ }^{b}$ This information was estimated based on the household budget survey for 2005.

\subsection{MACROECONOMIC DEVELOPMENT AFTER INDEPENDENCE}

Historically Kyrgyzstan was one of the poorest countries in the Soviet Union and heavily dependent in all aspects of the local economy on the centre in Moscow. The industrial sector mostly consisted of large enterprises closely connected through input and output chains with other republics. Official transfers from Moscow were about $10 \%$ of GDP during 1989-1991. External trade was mainly with the Soviet Republics, while export to the rest of the World was about $2 \%$ of total export (World Bank, 1993). This level of dependence made Kyrgyzstan very vulnerable after the breakup of the Soviet Union and led to substantial contraction of the Kyrgyz economy. The industry was most strongly affected due to abrupt cessation of subsidies from the centre, rapid growth of prices, loss of markets and previous connections with other republics (see figure 2.1). The resulting unemployment and boost in prices hit the population and resulted in increasing poverty and inequality with the bulk of poor people leaving in rural areas. ${ }^{8}$

Problems in the real sector coupled with the cessation of subsidies and the burden of relatively developed social sector led to widening of the budget deficit, which reached $13.2 \%$ of GDP in 1992 . The fiscal deficit was accompanied by a large

\footnotetext{
7 Vocational education does not belong to higher education in Kyrgyzstan and is a postsecondary professional education.

8 According to Milanovic (1998), Gini based on income per capita was 55, and the income poverty headcount ratio was about 88\% in 1993-1995 (poverty line was based on 120 international dollars per capita per month), higher than in any transition country that period.
} 
current account deficit due to worsening terms of trade. External borrowing resulted in high levels of external debt, which reached 124\% of GDP in 2000.

The socio-economic problems required a prompt response from the Kyrgyz Government. It was constrained in the available options and chose the liberal development path advocated by the World Bank and International Monetary Fund. The country was the first among the Central Asian republics to introduce its own currency - som. Price liberalisation was very fast, and by 1992 almost all prices were liberalised. The country eliminated export tariffs, established unified import tariff, abolished foreign exchange controls and entered the World Trade Organization in 1998, ahead of all CIS countries (Russia, Moldova, Ukraine, Georgia, Azerbaijan, Armenia, Belarus, Uzbekistan, Tajikistan, Turkmenistan, and Kazakhstan). ${ }^{9}$ The privatisation process was also rapid and included transferring small enterprises to current occupiers and operators and privatisation of large enterprises through a voucher scheme (Christensen \& Pomfret, 2007).

Reforms were heavily supported by international donor organisations and Kyrgyzstan was the largest recipient of technical assistance per capita and in \% of GDP in Central Asia (Mogilevsky \& Atamanov, 2008). About 13\% of all technical assistance was directed to the agricultural sector in 1996-2000 with a focus on such issues as land reform, farm management and micro-financing, but the excessive concentration of aid in the country's capital may have resulted in uneven development opportunities for rural areas (Cukrowski et al., 2002).

In spite of many unresolved institutional issues, the broad program of stabilisation and structural reforms brought positive results and after 1995 the economy started to grow. The driving force behind economic growth was the agricultural sector responsible in average for the half of growth for 1996-2002 (figure 2.2) and accounting for about 48\% of total employment in 1996-2004 absorbing additional labour ejected from industrial sectors (Lerman, 2007). The industrial sector resumed growth mainly due to investment in the Kumtor gold mine (World Bank, 1999). ${ }^{10}$ Economic growth slowed down in 1997-1998 due to problems in the banking sector and the effect of the Russian financial crisis. Zero and negative growth in 2002 and 2005 were caused mainly by exogenous factors: an accident in Kumtor gold mine and political turbulence in 2005. Importantly, after 2002 the growth was mainly generated in the services sector, while growth in agriculture almost disappeared (figure 2.2).

\footnotetext{
${ }^{9}$ The Commonwealth of Independent States is a regional organization whose participating countries are former Soviet Republics. Georgia withdrew from CIS in 2008. Turkmenistan is an unofficial member and Ukraine is not a member officially, but participating de facto.

${ }^{10}$ Kumtor gold mine is the single exploitable resource in Kyrgyzstan which played a dominant role in the economy after start-up of production in 1997. The Kyrgyz economy is very sensitive to this enterprise and zero economic growth in 2002 is related to a landslide shut down in the mine (Christensen \& Pomfret, 2007).
} 
Figure 2.1. Real growth rates of GDP in agriculture, industry and services, 19912008

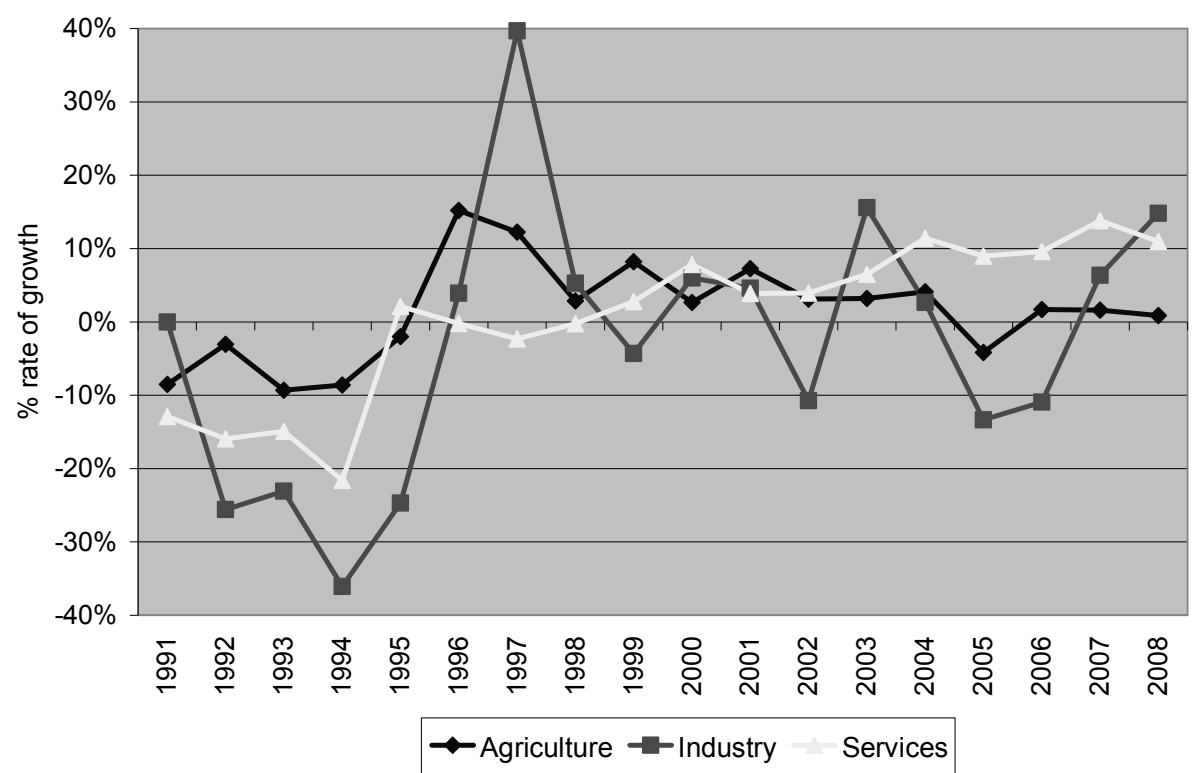

Source: NSC, author's calculation.

Table 2.2. Selected macroeconomic indicators

\begin{tabular}{|c|c|c|c|c|c|c|c|c|c|}
\hline & 1993 & 1996 & 1998 & 2000 & 2002 & 2004 & 2006 & 2008 & 2009 \\
\hline $\begin{array}{l}\text { Total GDP growth, } \\
\%\end{array}$ & -15.5 & 7.1 & 2.1 & 5.4 & 0.0 & 7.0 & 3.1 & 8.4 & 2.3 \\
\hline $\begin{array}{l}\text { Unemployment } \\
\text { level, \% }\end{array}$ & 1.7 & 7.8 & 5.9 & 7.5 & 8.6 & 8.5 & 8.3 & 8.2 & n.a. \\
\hline $\begin{array}{l}\text { Share of agriculture } \\
\text { in total } \\
\text { employment, \% }\end{array}$ & 39.0 & 47.2 & 49.0 & 53.1 & 49.0 & 38.9 & 36.3 & 34.0 & 32.4 \\
\hline $\begin{array}{l}\text { CPI, annual } \\
\text { change, } \%\end{array}$ & 1081 & 32 & 10.4 & 18.7 & 2.1 & 4.1 & 5.6 & 24.5 & 6.8 \\
\hline $\begin{array}{l}\text { Average Exchange } \\
\text { rate, som per USD }\end{array}$ & 6.1 & 12.8 & 20.8 & 47.7 & 46.9 & 42.7 & 40.2 & 36.6 & 42.9 \\
\hline $\begin{array}{l}\text { Overall budgetary } \\
\text { surplus/deficit, in \% } \\
\text { to GDP }\end{array}$ & -7.1 & -5.4 & -3 & -2.2 & -1 & -0.5 & -0.2 & 0.8 & -1.5 \\
\hline $\begin{array}{l}\text { Current account } \\
\text { deficit, in } \% \text { to GDP }\end{array}$ & -13.3 & -24 & -23.5 & -6.2 & -1.9 & 1.3 & -10.1 & -13.6 & -2.2 \\
\hline $\begin{array}{l}\text { Total external debt } \\
\text { in } \% \text { to GDP }\end{array}$ & n.a. & 63.9 & 90.6 & 124.6 & 110.2 & 95.0 & 77.6 & 49.1 & 66.5 \\
\hline $\begin{array}{l}\text { Private sector share } \\
\text { in GDP, } \%\end{array}$ & 25 & 50 & 60 & 60 & 70 & 75 & 75 & 75 & n.a. \\
\hline
\end{tabular}




\begin{tabular}{lccccccccc}
\hline & 1993 & 1996 & 1998 & 2000 & 2002 & 2004 & 2006 & 2008 & 2009 \\
\hline $\begin{array}{l}\text { Total GDP growth, } \\
\%\end{array}$ & -15.5 & 7.1 & 2.1 & 5.4 & 0.0 & 7.0 & 3.1 & 8.4 & 2.3 \\
\hline Agriculture & 41 & 50 & 39 & 37 & 37 & 37 & 32 & 31 & 27 \\
Industry & 26 & 12 & 18 & 25 & 25 & 19 & 19 & 15 & 18 \\
Services & 33 & 38 & 43 & 38 & 38 & 44 & 49 & 54 & 55 \\
\hline
\end{tabular}

Source: NSC, NBKR, EBRD, author's calculation.

Notes: while calculating the structure of GDP, taxes on products are excluded.

Economic growth after 2000 was accompanied by macroeconomic stabilisation in general. Inflation was brought down to the one digit level. Both fiscal and current account deficits decreased substantially. Poverty and inequality also decreased considerably. This period is characterised by a large inflow of remittances from labour migrants working in the growing oil-rich Russian Federation and Kazakhstan. According to the statistics from the National Bank of the Kyrgyz Republic (NBKR) the share of net remittances from workers in GDP increased from $5.6 \%$ in 2003 to $27.1 \%$ in 2008 . The only representative study of international labour migration and remittances conducted by the Asian Development Bank, showed 251 thousand migrants in 2006, mostly leaving rural areas in the South for the Russian Federation due to poor economic conditions, demographic pressure, and unemployment. ${ }^{11}$

After 2007, the economy continued to grow in spite of higher inflation and a larger current account deficit. Even the global economic crisis has had only a mild impact, and it was projected that the country would grow by $4.5 \%$ in 2010 . Yet political tensions and violent interethnic conflict in April-July 2010 made these growth prospects unattainable (ADB, IMF \& World Bank, 2010).

11 Detailed analysis of socio-economic characteristics of migrants using this survey is presented in chapter 5. An assessment of the impact of the financial crisis on Kyrgyz labour migrants is presented in OECD, ACTED and European Commission (2009). 
Figure 2.2. Mean contribution of different sectors to the total real growth rates of GDP, \%

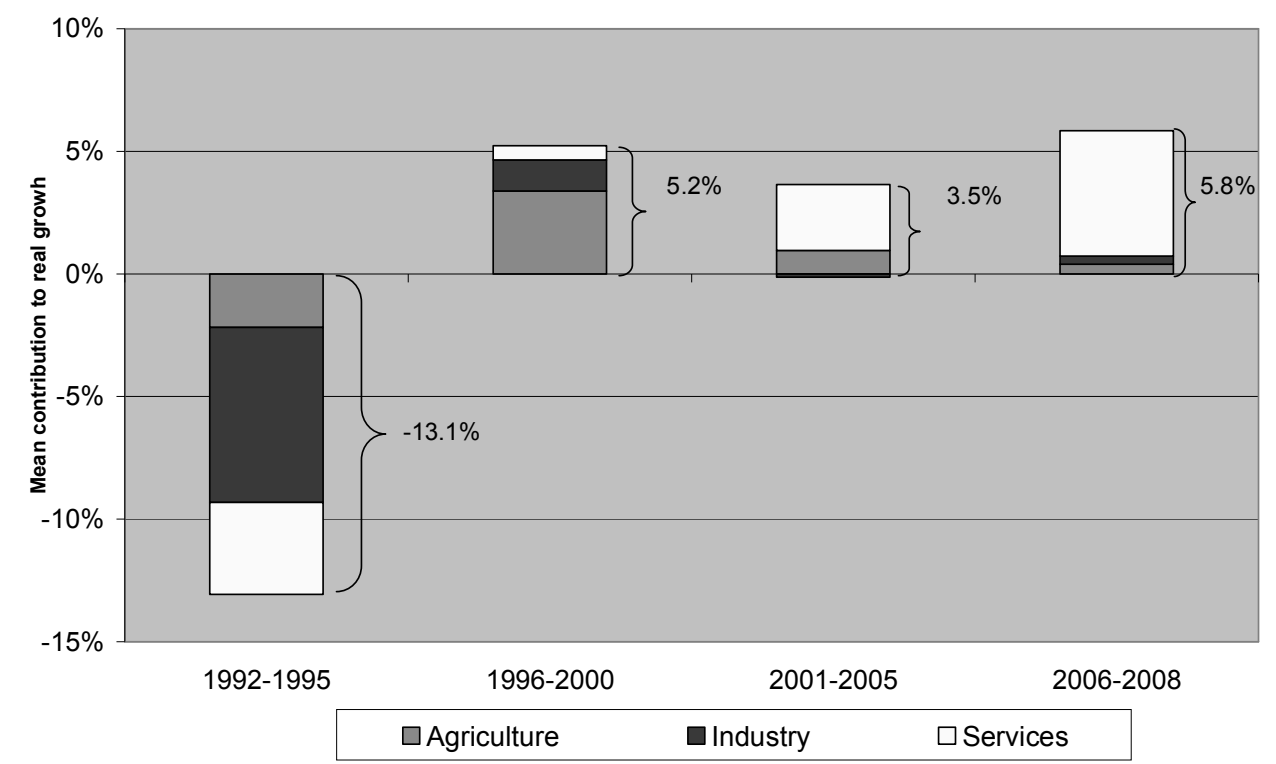

Source: NSC, author's estimation.

Note: Net taxes on products are not included. Contribution of a particular sector is estimated by multiplying its real growth on the share in total GDP.

\subsection{AGRARIAN REFORMS AND PERFORMANCE OF THE AGRICULTURAL SECTOR}

\subsubsection{Land reform and farm restructuring}

During the Soviet time, almost all land in Kyrgyzstan was owned by state or collective farms. Delehanty and Rasmussen (1996) showed that in 1990 four hundred forty two state and collective farms contained 15.2 of the Republic's 19.9 $\mathrm{mln}$. hectares of land. Each of these large enterprises managed thousands hectares of land and employed hundreds of workers. The process of land reform in Kyrgyzstan was supposed to move land from large state agricultural enterprises to small family-owned farms with land in private property. In order to do this, reforms were focused on the change in legal ownership of land from state to private property and the change from large corporate farms to individual farms. ${ }^{12}$

12 A comparative review of land reforms and agricultural performance among the Commonwealth of Independent States (CIS) is presented in Lerman (2007). The relationship 
Reforms in the agrarian sector can be broadly divided into three main phases. During the first phase (1991-1994) state subsidies were eliminated, markets were deregulated and prices were liberalised. In addition, state and collective farms were restructured into peasant farms, agricultural cooperatives, joint-stock companies and associations of peasant farms. However, according to Delehanty and Rasmussen (1996: 50), in practice there was only little difference between the new organisational forms and the old state and collective farms.

The most active second phase of the reforms (1995-2004) involved land reform and further reorganisation of agricultural enterprises. In a short period of time mass redistribution of transferable land shares resulted in $75 \%$ of all agricultural land being in individual use. The remaining 25\% was preserved in state ownership as a part of the Agricultural Land Redistribution Fund. Local selfgovernance units had the right to lease this land to rural residents. Till 1998 land still was state owned with land use rights of up to 99 years, but a country-wide referendum allowed private land ownership and finally a five-year moratorium on sales and purchases of agricultural land was lifted in 2001.

While the first and second stages of reforms in the agrarian sector were mostly related to the basics of land reform and farm restructuring, the third stage was concerned with supporting services and infrastructure. It started officially in 2004 and was supposed to focus on developing cooperatives, agri-businesses, credit cooperatives, agricultural insurance, development of seed and livestock selection, creation of an effective system for technical, agrochemical and veterinary, development of marketing, processing, and export systems for agricultural products and so forth (Lerman \& Sedik, 2009b).

The reforms resulted in the redistribution of land between new organisational types of farms. According to official legal classification, there are household plots, peasant farms, and corporate farms in Kyrgyzstan. Corporate farms are successors of large scale enterprises during the Soviet period and include now state and cooperative farms. They are much smaller after reorganisation and are run by hired managers. Land shares invested by individuals into the equity capital and leasing are main sources of land for corporate farms.

Peasant farms and household plots form the group of individual farms. Peasant farms operate mainly on family owned land and leased land from other owners. Small plot of land attached to rural residence is the main source of land for household plots. There is an overlap between these two categories as both of them mostly use family labour, but peasant farms have a commercial orientation and have larger size of land and are registered as juridical entities (Akramov \& Omuraliev, 2009).

between land tenure and agricultural recovery is also discussed in Lerman and Sedik (2009a). 
The land reforms resulted in a sharp increase in the number of farms and a shift of agricultural land from corporate to individual private farms. Thus, by 2009 there were 1,390 corporate farms accounting for 5.6\% of total sown area, 318,900 peasant farms accounting for $86.3 \%$ of total sown area and 924,100 household plots accounting for $8.1 \%$ of sown land. The distribution of land determined the average size of sown area per unit for different farm types. The average size of sown area for corporate farms was 65.1 ha, for peasant farms 3.1 ha and for household plots 0.1 ha (see table 2.3). An even more dramatic shift of resources from corporate to individual farms occurred with regard to the size of cattle herds. State and collective farms owned 55\% of total cattle stocks in 1990 and only 1\% in 2009. Similarly, state and collective farms owned $81 \%$ of total sheep herds in 1990 and only 1\% in 2009 (NSC). In sum, the conducted reforms led to sharp decollectivisation, individualisation and privatisation of the agricultural sector in the Kyrgyz Republic.

Table 2.3. Main characteristics of farm types in Kyrgyzstan, 2009

\begin{tabular}{lccc}
\hline & $\begin{array}{c}\text { Corporate } \\
\text { farms }\end{array}$ & $\begin{array}{c}\text { Peasant } \\
\text { farms }\end{array}$ & $\begin{array}{c}\text { Household } \\
\text { plots }\end{array}$ \\
\hline Number, thousand & 1.39 & 318.8 & 924.1 \\
Sown area, thousand ha & 65.1 & 1009.2 & 95.3 \\
Average size of sown area per unit, ha & 46.8 & 3.2 & 0.1 \\
Share in sown area, $\%$ & 5.6 & 86.3 & 8.1 \\
\hline
\end{tabular}

Source: NSC, Akramov and Omuraliev (2009).

\subsubsection{Performance of agricultural sector}

Changes in organisational forms of farms accompanied by land reform had a substantial impact on the performance of the agricultural sector. In spite of a deep decline in the beginning of the transition process, robust growth resumed in 1996 coinciding with the most active phase of reforms. As shown in figure 2.3, crop production was the main source of growth in the agricultural sector outperforming cattle breeding. Moreover, the structure of agricultural output has changed and crops took the leading share fluctuating around $56 \%$ of gross agricultural output (GAO) during 1999-2008.

The agricultural sector was the engine behind the economic growth in 1996-2001 and it was the only sector that recovered beyond the pre-1990 output level. Agricultural growth was not caused by an increase in resources but was driven by higher land and labour productivity: only agricultural labour increased while sown area decreased by 124 thousand ha from 1990 to 2009 and was accompanied by sharp decline in machinery and fertilisers (Lerman \& Sedik, 2009b). 
Figure 2.3. Shares of crops and livestock in gross agricultural output (GAO) and rates of growth

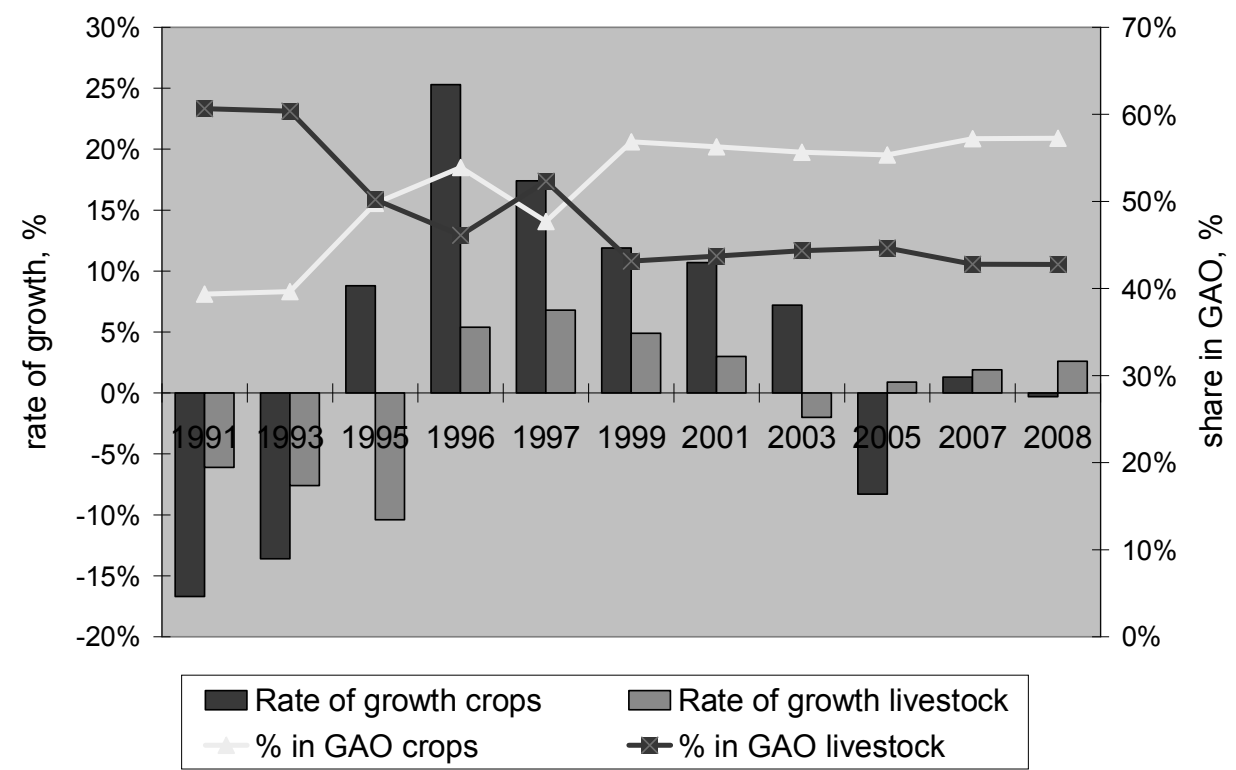

Source: NSC, author's calculation.

Land and labour productivity are shown in figure 2.4. In the early 1990s, labour productivity dropped substantially due to negative agricultural growth and absorption of a large number of unemployed people ejected by industrial sector. Afterwards, changes in institutional structure of agriculture led to increase of agricultural productivity and the recovery of agricultural production (Akramov \& Omuraliev, 2009). After 2002 land productivity slowed down, while labour productivity continued to grow driven by the decline in agricultural employment, when rural residents moved to other sectors of local economy or migrated.

There is consensus in the research community that farm restructuring and land reform were the crucial factors explaining the fast development in the sector (Light, 2007; Lerman \& Sedik, 2009b). ${ }^{13}$ Reforms transferred decision-making power and resources to private individual farmers who allocated their resources according to household preferences and market conditions and become the most

${ }^{13}$ Kyrgyzstan was considered an advanced reformer according to ECA agricultural policy index. The ECA agricultural policy reform index consists of five components, measuring progress with land reform, liberalisation of agricultural markets, privatisation, the institutional framework and rural finance. It is constructed on the scale from 1 to 10, with 10 meaning an economy with completed market reforms. The index for Kyrgyzstan was 7.4 in 2004, making it an advanced reformer among Former Soviet Union countries (Lerman, 2007). 
important producers in agricultural sector as shown below (Akramov \& Omuraliev, 2009).

\section{Figure 2.4. Land and labour agricultural productivity during 1991-2009 years, thousand som}

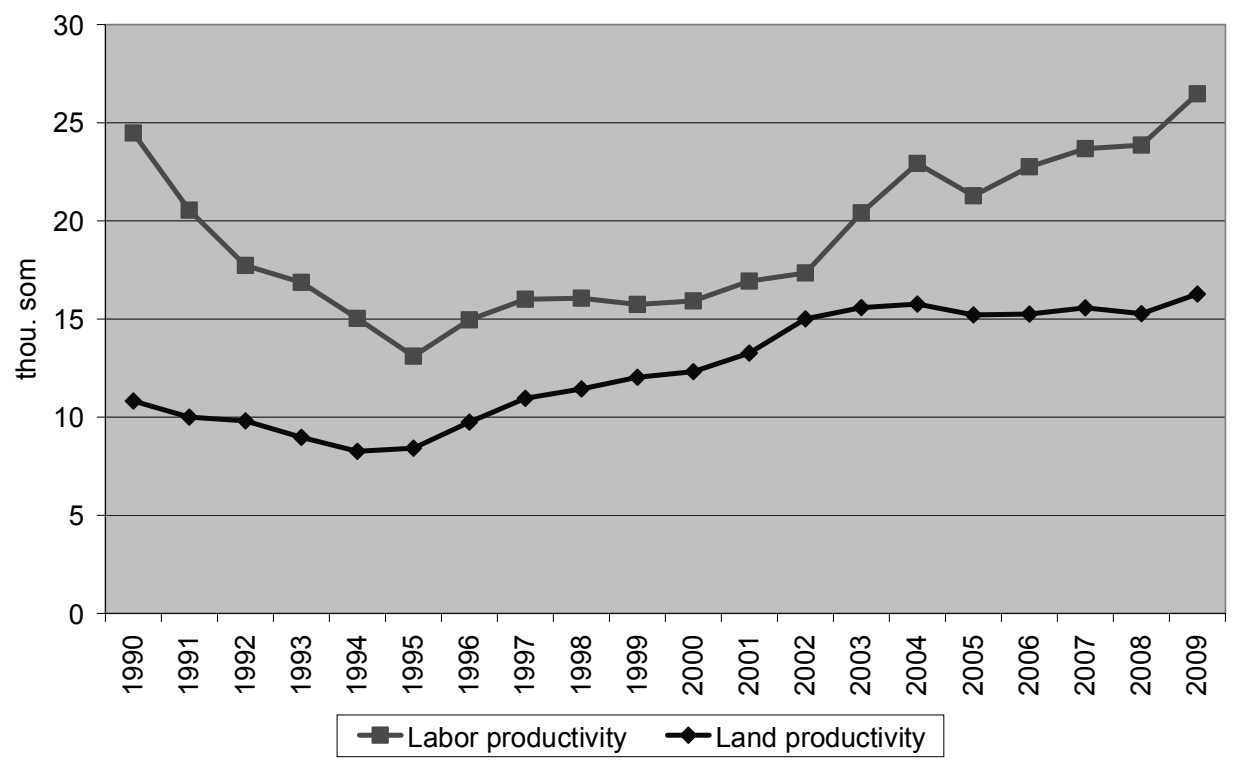

Source: NSC, author's calculation.

Notes: Labour and land productivity are measured as the value of agricultural GDP in constant 1990 prices per worker employed in the agricultural sector and per hectare of harvested area.

Firstly, individual farms became the main source of agricultural output. The share of corporate farms shrunk from a substantial 55\% of GAO in 1991 to 2\% in 2008 as they were substituted by peasant farms. Secondly, individual farmers shifted from forage crops to high-value crops (vegetables, fruits, melons) to supplement their income and to cereals for food self-sufficiency purposes. For example, the share of fodder in total harvested areas decreased from 50\% in 1990 to $24 \%$ in 2009 , while the share of grain increased from $42 \%$ to $56 \%$ and the share of vegetables and melons increased from $4 \%$ to $12 \%$ the same period (NSC). 
Figure 2.5. The structure of gross agricultural output across farm types

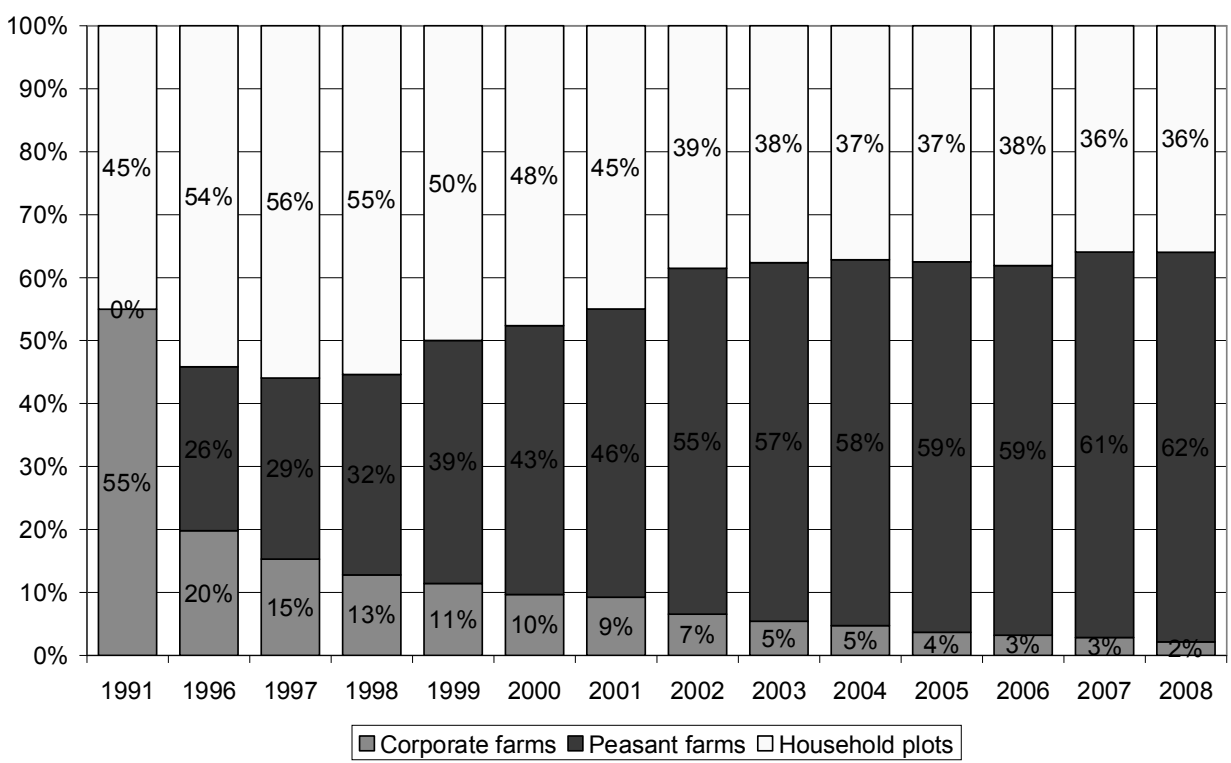

Source: NSC, author's calculation.

Production of vegetables increased from 487.3 thousand tonnes in 1990 to 832.5 thousand tonnes in 2009, potatoes from 365.1 thousand tonnes to 1391.3 thousand tonnes, melons from 71.4 thousand tonnes to 137.2 thousand tonnes accordingly. In livestock, the growth in production of main products was only observed in milk production, while production of eggs, meat and wool declined. This is related to the modest growth in cattle and large decline in the size of sheep herds during the transition period.

The final and the most important evidence of the leading role of private farms in agricultural growth is related to the high productivity of households and peasant farms. Two land productivity indices are shown in figure 2.6. Gross agricultural output in million som is divided by sown area in thousands hectares in the first index. We also use a second measure of productivity which compares shares in agricultural output and shares in sown area. All farms together produce $100 \%$ of GAO using $100 \%$ of land. If the indicator is larger than one this means that land is being using more efficiently than the average for the entire sector (Lerman \& Sedik, 2009b). As shown in figure 2.6, households outperform corporate and peasant farms. ${ }^{14}$ Corporate farms have the lowest land productivity, indicating that they use the large land resources they control inefficiently.

14 Similar findings were mentioned in Akramov and Omuraliev (2009), Lerman and Sedik (2009b). Moreover, outperforming of households is found in other Central Asian countries as well, but there is not difference between productivity of peasant farms and enterprises in 
Figure 2.6. Land productivity across farm types, 2009

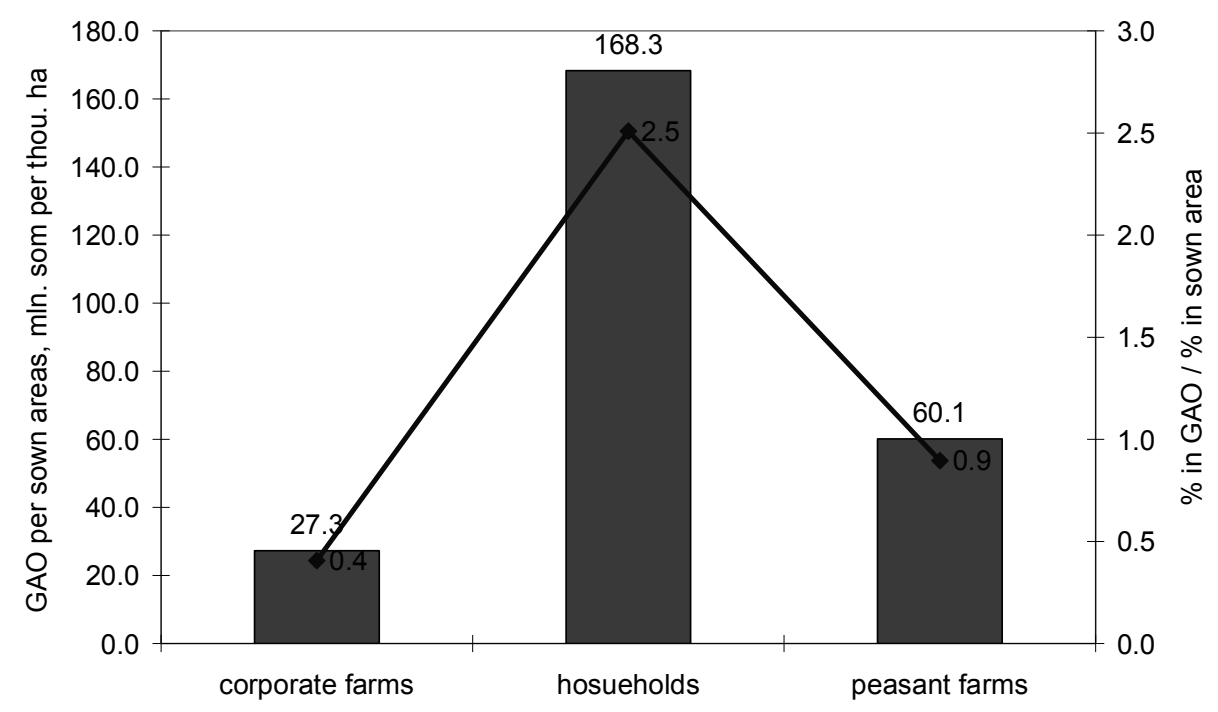

$\square$ GAO per sown area, mln som per thou. ha $\rightarrow$ Relative productivity, $\%$

Source: NSC, author's calculation.

We saw that the shift to individual farming was one of the main factors responsible for the resumption of agricultural growth after 1995. However, after 2001 growth slowed down and even became negative in 2005 during political turmoil. Intensive farming and rotation to high-value crops were not able to sustain the growth rates, and paradoxically individualisation of agriculture transformed from a source of growth to a "curse of smallness" reflected in lack of access to machinery (too expensive), to credit (lack of collateral, high transaction costs), having difficulties in selling products (small quantities for buyers and too high transport costs) (Lerman \& Sedik, 2009b). In order to overcome these problems adequate institutions are needed to help small farms in product marketing and getting access to inputs and machinery. The development of institutions in rural areas is discussed in the next section.

\subsection{DEVELOPMENT OF INSTITUTIONS IN RURAL AREAS: UNFINISHED AGENDA}

The slowing agricultural growth after 2000 is often explained by the fact that land reform and farm restructuring were not accompanied by reforms of the farm support services and infrastructure, which used to serve large-scale enterprises in

Uzbekistan and Tajikistan (Lerman \& Sedik, 2009a). The authors explain the situation in Tajikistan by unchanged management structure. 
the Soviet Union. These unfinished reforms were important factors constraining sustainable growth in the sector (Light, 2007; Lerman \& Sedik, 2009b). We group institutional issues into broad categories related to land market, access to credit resources and machinery, and access to agricultural services.

Before considering particular groups of institutional issues, a broad review of transition and doing business indicators is presented in figure 2.7 and table 2.4.

\section{Figure 2.7. Transition indicators in Central Asian countries, 2008}

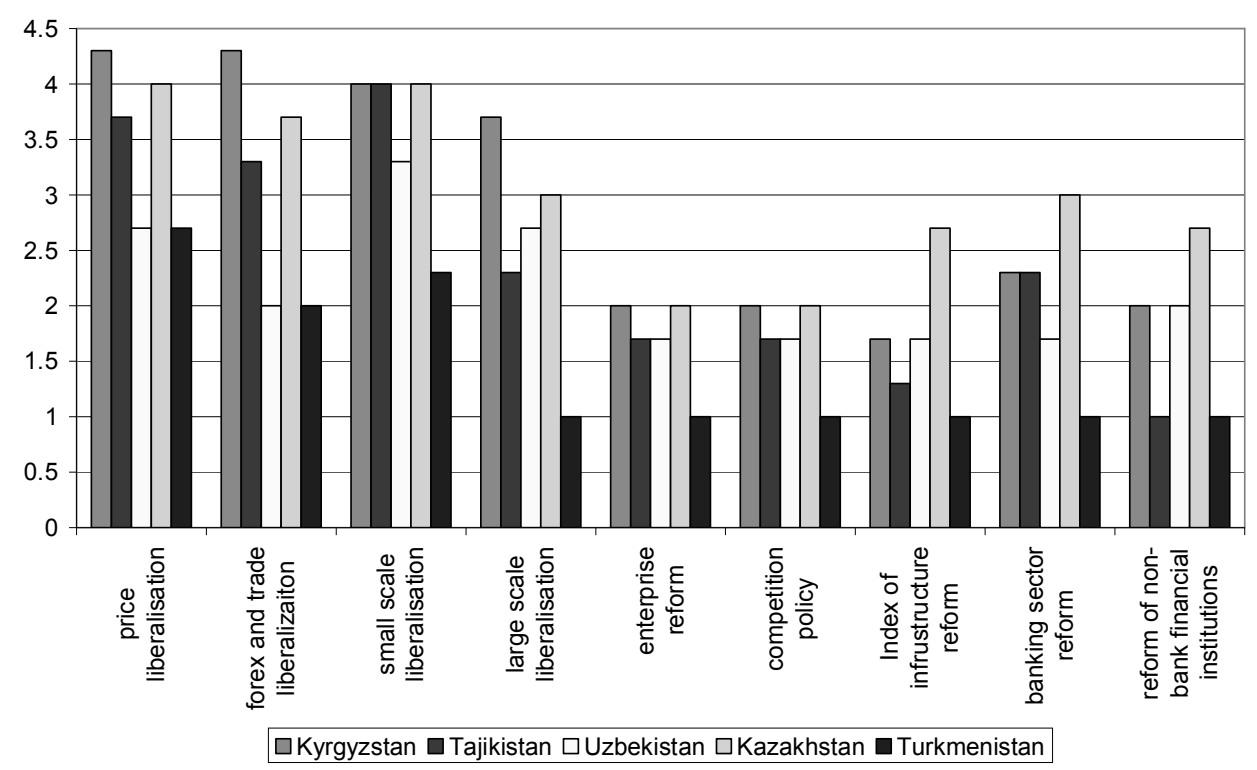

Source: EBRD

Notes: Transition indicators measure progress in transition to a market economy and range from scores 1 to 4.3 . A higher score means better progress.

After two decades of transition the Kyrgyz Republic has made relatively good progress towards the standards of advanced market economies relative to other countries in the region. Only oil rich Kazakhstan outperforms Kyrgyzstan in infrastructural reforms and development of banking and nonbank financial institutions, while in price and trade liberalisation, small and large scale privatisation Kyrgyzstan was the leader in 2008. With regards to business regulation and the protection of property rights, Kyrgyzstan again performed better in comparison to other poor Central Asian countries in 2006 (Tajikistan and Uzbekistan), but lagged behind Kazakhstan in the tax burden and costs of starting a business (table 2.4). 
Table 2.4. Selected doing business indicators for Kyrgyzstan, Kazakhstan, Uzbekistan, and Tajikistan ${ }^{15}, 2006$

\begin{tabular}{lcccccc}
\hline & Starting a business & $\begin{array}{c}\text { Registering } \\
\text { property }\end{array}$ & $\begin{array}{c}\text { Getting } \\
\text { credit }^{\text {a }}\end{array}$ & $\begin{array}{c}\text { Paying } \\
\text { taxes }\end{array}$ & $\begin{array}{c}\text { Enforcing } \\
\text { contracts }\end{array}$ \\
\hline $\begin{array}{c}\text { Time } \\
\text { (days) }\end{array}$ & $\begin{array}{c}\text { Cost (\% of } \\
\text { income per } \\
\text { capita) }\end{array}$ & Time (days) & $\begin{array}{c}\text { Strength of } \\
\text { legal rights } \\
\text { index (0-10) }\end{array}$ & $\begin{array}{c}\text { Total tax } \\
\text { rate }(\% \\
\text { profit) }\end{array}$ & Time (days) \\
\hline Kyrgyzstan & 21 & 10.4 & 8 & 6 & 68.2 & 260 \\
Kazakhstan & 25 & 8.6 & 52 & 4 & 44.4 & 390 \\
Tajikistan & 80 & 85.1 & 37 & 3 & 82.1 & 430 \\
Uzbekistan & 29 & 14.1 & 78 & 2 & 96.7 & 195 \\
\hline
\end{tabular}

Source: International Finance Corporation and the World Bank.

Notes: athe index ranges from 0 to 10 , with higher scores indicating that collateral and bankruptcy laws are better designed to expand access to credit.

Unfortunately, positive tendency in transition indicators was not accompanied with improving governance effectiveness in the Kyrgyz Republic. In contrast, as shown in figure 2.8, Kyrgyzstan was able to improve only regulatory quality and voice and accountability rating during 1996-2007 years, while for other indicators the situation has become substantially worse. For example, Kyrgyzstan has moved to the lowest tenth percentile by 2007 in control of corruption and the rule of law. The same negative tendency is observed with regards to political stability and governance effectiveness signalling significant problems with governance.

Coming back to the development of institutions in rural areas, land market in particular, empirical studies show that that there is a high demand for land in Kyrgyzstan. For example, among 140 surveyed farmers and agricultural enterprises $64 \%$ would buy land if this were possible in their community (USAID, 2008). According to the same study, the current legislation limits private ownership of land to the residents of rural areas above 18 years old residing in a given community at least for two years. This clearly restricts participation of urban citizens, juridical entities, foreigners and local self-governance units in the land market, which in its turn limits potential demand and keeps land prices low. Moreover, limitations on ownership of land by juridical entities restrict the utilisation of land as collateral, as commercial banks are either reluctant to take it or value it far below market prices.

${ }^{15}$ Data for Turkmenistan are not available. 
Figure 2.8. Governance indicators for Kyrgyzstan in 1996 and 2007, percentile rank

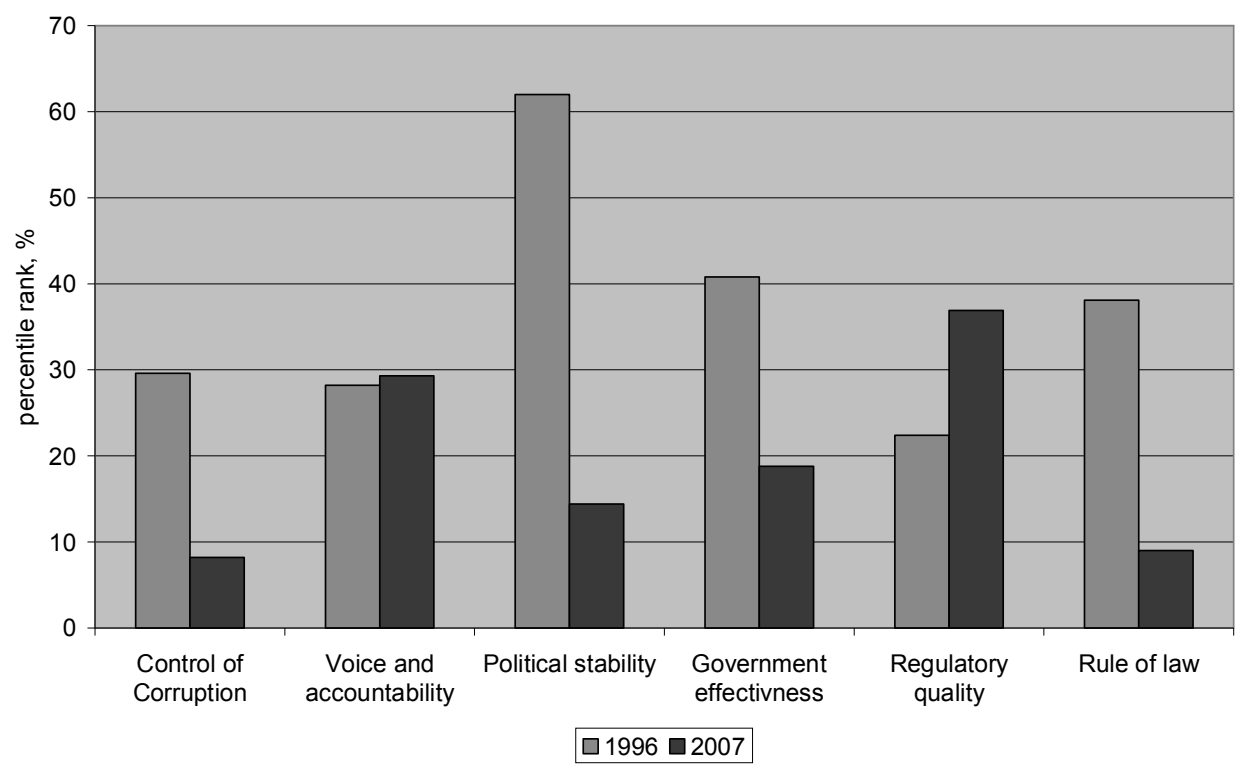

Source: Kaufmann et al. (2010).

Notes: Percentile rank indicates rank of the country among all countries in the world. Zero corresponds to the lowest and 100 to the highest rank.

Demand for land is partially satisfied by leasing, which is legally allowed between citizens of Kyrgyzstan and is based on mutual agreement. According to USAID (2008), about $50 \%$ of peasant and corporate farms lease land from other farmers and Local Redistribution Funds. ${ }^{16}$ The share of short-term leasing (one year) is higher among peasant farms (30\%) relative to corporate farms (9\%). Akramov and Omuraliev (2009) consider short-term land lease agreements potentially harmful for long-term investment in land.

Developing a commercial rural credit system has always been on the agenda of the Kyrgyz Government and the international donor community. Substantial reforms, widely supported by the World Bank and the Asian Development Bank, have been conducted aimed at restructuring the large debt of the agricultural sector to several state banks and the Government, and replacing the old system of state directed and subsidised credit with a new commercial credit system (Mudahar, 1998). The World Bank financed FINSAC programme aimed at: (i) creation of a policy and regulatory environment conducive to development and growth of sound private banking system and non-bank financial institutions; (ii)

${ }^{16}$ This survey is not representative at the country level. 
liquidation of insolvent banks and creation of a temporary debt resolution agency to restructure, sell or write-off the old nonperforming loans.

In rural areas the focus was on the promotion of microfinance. The Kyrgyz Agricultural Financial Corporation (KAFC) was established in 1996 with the support of the World Bank to provide sustainable finance to farmers and agricultural enterprises. In 2006 it was reorganised into Aiyl Bank. In 1997 the Financial Company for Support and Development of Credit Unions was established. It was mainly financed through a loan from the Asian Development Bank to develop agricultural financing in rural areas and to promote creation of credit unions and provide them with technical advice and support.

Besides these large organisations, numerous credit unions and microfinance organisations have been established. According to the National Bank (2010), there were 359 microfinance organisations and 238 credit unions by the end of 2008. The credit portfolio of these nonbank credit organisations expanded ten times from $723 \mathrm{mln}$. som in 2003 to $7339 \mathrm{mln}$. som in $2008 . .^{17}$ Loans from microfinance organisations form the majority of the credit portfolio $(89 \%)$. The agricultural sector accounted for $37 \%$ of total credit portfolio of nonbank credit organisations in comparison to $11.5 \%$ of commercial banks in 2008 (table 2.5).

Table 2.5. Characteristics of the credit portfolio of commercial banks and nonbank credit organisations, 2008

\begin{tabular}{lccc}
\hline & $\begin{array}{c}\text { Credit } \\
\text { portfolio, } \\
\text { mln. som }\end{array}$ & $\begin{array}{c}\text { Share of credits } \\
\text { to agricultural } \\
\text { sector }\end{array}$ & $\begin{array}{c}\text { in \% to } \\
\text { GDP }\end{array}$ \\
\hline $\begin{array}{l}\text { Nonbank credit } \\
\text { organisations }\end{array}$ & 7339.0 & $36.8 \%$ & $3.9 \%$ \\
Commercial banks & 25607.9 & $11.5 \%$ & $13.6 \%$ \\
\hline
\end{tabular}

Source: NBKR, author's calculation.

Development and expansions of the credit market had a positive impact on the access of rural citizens to credit resources. A survey of farmers conducted by MVector (2007) showed that the percentage of farmers who used credit resources increased from $3 \%$ in 2003 to $20.6 \%$ in 2007 . Nevertheless, the level of financial intermediation is still very low. The banking system is not trusted among the population and it is not competitive (Light, 2007). For example, the total loan portfolio of commercial banks and nonbanking credit organisations accounted only for $17.5 \%$ of GDP in 2008 and only $17.9 \%$ of firms used banks to finance investment in 2009. This is lower than the figures for Armenia (31.9\%), Mongolia (26.5\%), and Tajikistan (21.4\%). In 2009 the interest rate spread between lending and borrowing was also the highest in Kyrgyzstan (15.9\%) among other Former Soviet Union

\footnotetext{
17 We excluded KAFC from estimation in 2003 and included it to commercial banks in considered years.
} 
countries, reflecting the weakness of the Kyrgyz banking system. For comparison, the interest rate spread was $14.4 \%$ in Tajikistan, $10.9 \%$ in Georgia, $10.4 \%$ in Armenia and 7.5\% in Azerbaijan (World Bank, 2009).

Interest rates for credits from credit unions and nonbank credit organisations are higher than those from commercial banks, but commercial banks are reluctant to lend rural residents. This creates also strong bias against rural lending reinforced by a limited branch network in rural areas, the low value of collateral, insufficient liquidity of credit unions, and low awareness of financial services (Dall'Olio, 2008).

Inadequate access to credit is one of the main factors that limit farm mechanisation and productivity in the agricultural sector. Moreover, the prevalence of short-term resources in the financial sector inhibits the development of leasing as an alternative to traditional loans (Guadagni \& Fileccia, 2009). These authors showed that the Kyrgyz Republic had fewer tractors per hectare than any comparable country in CIS. Moreover, the existing park of machines is very old, since only 9 percent of tractors and 14 percent of combine harvesters have been replaced since 1990. Lack of farm machinery reduces the usefulness of investing in seeds and fertilisers, since machines are required both at the beginning for preparation of seedbeds and in the end for harvesting. As shown in Guadagni and Fileccia (2009), old machinery and delayed harvests increase usual harvest losses by $15-25 \%$. Total financial needs to close agricultural machinery gap are assessed to be about $400 \mathrm{mln}$. USD. This gap is difficult to address in the short run.

The last important group of institutional issues the Kyrgyz farmers face is related to agricultural services. During the Soviet period a system of special agricultural schools conducting research and teaching the best technologies to future farmers existed. In addition, all state and collective farms had special staff responsible for providing agricultural services (Light, 2007; Akramov \& Omuraliev, 2009). During the transition period the whole system was dismantled. Moreover, the farm structure has changed tremendously from large state collective farms to small peasant farms and households, which calls for a new system of agricultural services. Field surveys demonstrated that new farm owners experienced lack of knowledge in farming or had specialised knowledge relevant for large-scale agricultural production, but not applicable in the current circumstances (World Bank, 1998).

Akramov and Omuraliev (2009) mentioned that creation of institutions to provide agricultural support services was almost neglected in the early stages of transition process. ${ }^{18}$ More active work started at the end of 1990s. Several institutions were created in the framework of the Agricultural Support Services project financed by the World Bank and several other bilateral agreements. For

18 There were several pilot projects financed by Swiss Aid, TACIS, GTZ to test out the provision of farm advisory services to emerging private farms (World Bank, 1998). 
example, the Rural Advisory Service (RAS) was created in 1999 to provide advisory (extension) services to peasant farmers. The Legal Assistance to Rural Citizens (LARC) was created in 2000 to provide legal aid to rural population. In spite of the active promotion and work of these institutions, farmers' awareness about these services and their utilisation is still quite low. For instance, according to M-Vector (2007), only $19.7 \%$ of farmers knew about RAS and $15.9 \%$ used their services. With regards to LARC, $7.2 \%$ were aware about this institution and only $3.1 \%$ applied for services.

Several other institutional problems typical for rural areas are worth mentioning. Lack of mechanisms to enforce contracts seriously limits the development of stable long-term relationships between farmers and agroprocession companies, thus preventing increased certainty and related possibilities for expansion (Light, 2007). Other important problems include access to rural physical infrastructure in general and irrigation water in particular exacerbated by high land fragmentation and deterioration of excising facilities. According to MVector (2007), farmers most frequently mentioned problems with irrigation after problems with the shortage of agricultural machinery. In sum, an unfinished agenda on establishing and adjusting rural institutional environment for benefiting small individual farms hamper the long-term benefits from the land reform and endanger sustainable growth in the agricultural sector of the Kyrgyz Republic.

\subsection{POTENTIAL IMPACT OF CHANGES IN RURAL AREAS ON THE RNFE DEVELOPMENT}

Let us consider how changes in the agricultural sector and institutional environment can potentially shape the magnitude and income from nonfarm activities. The agricultural sector is one of the main factors influencing the size and composition of the RNFE, since it is the largest employer and the largest source of income in rural areas. According to dynamic linkages models, a growing agricultural sector can provide more raw inputs for upstream sectors, stimulating processing and packaging industries (forward linkages) or alternatively it can demand inputs from the producers of farm equipments, fertilisers and services (backward linkages), stimulating their development (Haggblade et al., 2007). In particular, modernised and large scale agricultural activities require more nonfarm inputs than small-scale traditional agricultural activities (Haggblade et al., 2002). Taking into account that strong and robust growth in the agricultural sector was mainly driven by small farms and households, one should not expect a strong expansion of nonfarm activities due to forward linkages. Moreover, the effect of backward linkages may also be weaker due to low mechanisation and small-scale production in the farming sector in Kyrgyzstan.

The agricultural sector can also stimulate nonfarm activities through consumption effects when farm income is spent on non-food products and 
services. The impact depends on the distribution of income and land in the farm sector. Rich households usually have higher budget shares of non-food expenditures and this may create stronger demand in developed agricultural areas with higher concentration of rich households (Islam, 1997). Obviously, high rates of agricultural growth and associated decreases in poverty levels imply that rural households increase their consumption in general and their consumption of nonfarm products and services in particular. Nevertheless, the potential of poor rural residents with limited land resources to stimulate strong consumption effects is questionable.

Growth and consumption linkages are based on the assumption of a dynamic agricultural sector. However the RNFE has a different nature in stagnant rural areas with lack of arable land, water, and risky weather conditions. In the presence of incomplete credit and insurance markets, farmers are often pushed into non-farming in these areas, and due to low agricultural productivity and low purchasing power, these activities are labour-intensive with low-returns (Ellis \& Allison, 2004; Haggblade et al., 2007). This scenario is also relevant for the Kyrgyz Republic, especially in the South, where high population pressure and lack of arable land can "push" the poorest into nonfarm activities.

It is important to mention that the same factors driving non-farm activities can easily constrain at least some of them. Thus, the unfinished institutional agenda does not only inhibit robust agricultural growth, but can negatively affect development of the RNFE as well. For example, imperfect credit markets and inability to use land as collateral in Kyrgyzstan may discourage diversification into non-farm activities with high capital requirements. The lack of contract enforcement can seriously challenge the chains between farmers and processing companies. Inadequate access and development infrastructure can constrain participation in the RNFE through higher costs.

In sum, in spite of all positive changes in the agricultural sector of the Kyrgyz Republic due to land reform and farm restructuring, its potential is still constrained because the institutional environment is not developed and shaped to serve individualised small farming. In turn, stagnation in agricultural sector, the lack of large-scale commercialised farms and rural market imperfections may limit the development of highly productive nonfarm activities, and can push the labour force into a low paying and labour intensive RNFE. This hypothesis is tested in chapters 3 and 4 . 


\section{RURAL NONFARM ACTIVITIES IN THE KYRGYZ REPUBLIC: A REGIONAL ANALYSIS OF MAGNITUDE, STRUCTURE, EVOLUTION AND DRIVERS ${ }^{19}$}

This chapter provides an in-depth regional analysis of the rural nonfarm economy (RNFE) in Kyrgyzstan based on three household budget surveys for 2003, 2005 and 2006. Regression analysis reveals that the share of time spent in the commercial RNFE was larger in rayons (districts) with low agricultural potential, indicating that the rural poor are pushed into accessible but not necessarily very profitable nonfarm activities. This "push" scenario is probably strengthened by the low commercialisation and unfinished institutional reforms in the agricultural sector. Only in a few land-rich rayons and in a rayon with a famous resort was labour "pulled" into a profitable RNFE stimulated by agricultural development and other local "motors" of growth.

\footnotetext{
19 The article underlying this chapter was co-authored by Marrit van den Berg and was accepted for publication in Europe-Asia Studies. We are thankful to two anonymous referees for their helpful comments and suggestions to improve the paper. This paper is also available as: Atamanov, A. and Van den Berg, M. (2010). Rural Non-Farm Activities in Central Asia: A Regional Analysis of Magnitude, Structure, Evolution and Drivers in the Kyrgyz Republic. Working paper 005. Maastricht University. Maastricht Graduate School of Governance.
} 


\subsection{INTRODUCTION}

After almost three decades of economic reforms, more than half of the population of the three poorest transition countries in Central Asia-Tajikistan, Uzbekistan and Kyrgyzstan- still lives in rural areas with high population pressure and widespread poverty and unemployment. ${ }^{20}$ Following the collapse of the Soviet Union, both industrial and agricultural production dwindled. Existing organisations were broken down, and new economic structures had to be developed. Several studies have analysed the nature and consequences of the associated agricultural reforms (for example, Rozelle \& Swinnen, 2004; Lerman, 2007). Yet, there is an almost complete lack of empirical evidence on the development of the rural nonfarm economy (RNFE) and its drivers in the context of post-Soviet Central Asia.

Developing agriculture is not sufficient to address income disparities and to transform countries (Davis \& Bezemer, 2003). Also development of industry and services is required to generate income and provide employment, not only in towns but also in rural areas. The RNFE has a potential to absorb surplus rural labour, to overcome seasonal income variability of agricultural activities, and to provide income in case of droughts and the loss of livestock (Lanjouw \& Lanjouw, 2001; Ellis, 2004). This makes the RNFE important for rural households and especially for the poor and vulnerable in the context of imperfect insurance and credit markets, and weak safety nets (Barrett et al., 2001).

In order to develop efficient policies to stimulate rural economic growth, policymakers need an insight in the nature and drivers of the RNFE (Reardon et al., 2006). If participation in the nonfarm sector is driven by new opportunities and high pay-offs, policies need to aim at helping the poor to overcome existing entry barriers through for example credit programs, marketing assistance, or training. If, on the other hand, people participate in the nonfarm sector due to the lack of opportunities in farming, nonfarm policies should have a more general focus on the development of the nonfarm economy through increasing general access to markets, competitiveness with industrial products, and the development of knowledge and skills.

The main goal of this chapter is to analyse recent developments in the RNFE and its drivers at the regional and rayon (district) levels in the Kyrgyz Republic. We employ three household budget surveys from the National Statistical Committee (NSC), which provide accurate representative information on rural nonfarm employment and rural nonfarm income in 2003, 2005 and 2006. Kyrgyzstan is a very interesting case to explore. It has substantial variation in regional development and agro-climatic conditions. It is a poor and predominantly

${ }^{20}$ Kazakhstan is relatively rich country and there is almost complete lack of any statistical information on Turkmenistan. 
rural country with $65 \%$ of the population residing in rural areas and agriculture generating 27\% of Gross Domestic Product in 2009. Kyrgyzstan is also one of the largest recipients of development aid in the region and the most advanced agricultural reformer. The obtained results can enrich empirical evidence on the nature and driving forces of the RNFE in transition countries and provide valuable information for Kyrgyz and possibly other Central Asian policymakers.

The layout of this chapter is as follows. It starts with a discussion of the conceptual framework. Then the magnitude and structure of the RNFE are presented at the regional level for 2003, 2005 and 2006 years. We specify the empirical model and discuss the main results in the next section. The last section concludes.

\subsection{CONCEPTUAL FRAMEWORK}

\subsubsection{Concepts and definitions}

Two conceptual issues should be clarified before starting the analysis of the RNFE. Firstly, what is a rural area? Secondly, what does nonfarm mean? The answer to the first question depends mainly on the available data. Different criteria can be used: population size (Barrett \& Reardon, 2000), population density (Organisation of Economic Co-operation and Development, 2006), municipal and government functions (Saith, 1992), and so forth. In this paper, the data have a predetermined administrative division into urban and rural areas, where rural areas cover localities with populations not less than 50 inhabitants with at least half of the population engaged in agricultural activities.

There is a lot of confusion in the literature about the definition of nonfarm economic activities. Several authors describe and discuss these issues in details (for example, Barrett \& Reardon, 2000; Davis \& Bezemer, 2003). Barrett and Reardon (2000) advocate a distinction between nonfarm and farm activities based on the sectoral division between primary versus secondary and tertiary sectors as commonly used in national accounts. Using this approach, farm activities include primary agricultural activities, forestry and fishing aimed at producing raw products with natural resources as production factors. The process can involve either "growing" (cropping, livestock) or "gathering" (hunting, fishing, etc). Nonfarm activities, in contrast, include all other income generating activities in secondary (manufactured goods) and tertiary (services) sectors. This sectoral separation does not take into account technologies used and type of income (wage, profit, etc.). We follow this approach and consider employment in all sectors except agriculture and fishing as nonfarm employment regardless of whether it concerns wage or self-employment.

We distinguish two types of nonfarm activities. Following World Bank (2007), we classify nonfarm employment financed mainly through state or local 
government budgets as public employment. This includes education, public administration, health and social services. The remainder of nonfarm employment is commercial employment and includes both private sector employment and provision of public services on a commercial basis. We used this distinction because commercial nonfarm activities are likely to have different determinants than those financed through public budgets and we are particularly interested what stimulates commercial initiatives. We exclude migrants from the analysis and only analyse local employment of rural inhabitants, as we are interested in local development of the RNFE as a potential alternative to widespread labour migration.

The magnitude of the RNFE can be measured by three commonly used methods. The first estimates the mean share of nonfarm income in total household income, controlling for seasonality and consumption of own products. The second method is to estimate the share of people employed in nonfarm activities taking both primary and secondary nonfarm activities into account. The third method estimates the share of time in nonfarm activities to total time worked. In this study, we use all three methods to arrive at a broad and accurate picture of the RNFE.

\subsubsection{Determinants of nonfarm activities at the regional level}

The determinants of nonfarm activities at the household level are often conceptualised as incentives and capacity variables (Reardon et al., 2006). The relative prices of inputs and outputs, along with their relative instability/riskiness, act as incentives for either engaging in the farm or the nonfarm sector. Capacity variables, such as human, financial and physical capital are typical factors that shape access to nonfarm activities by helping to overcome skills-based and financial barriers and lowering transaction costs.

One of the main factors influencing incentives is the development of agriculture. Nonfarm activities may develop in stagnant rural areas with lack of land, water, and capital, and risky weather conditions. Low agricultural productivity and limited purchasing power often "push" farmers into nonfarm activities in these areas. These activities are often labour-intensive with low-returns (Haggblade et al., 2007). A "push" scenario may also happen in very remote areas with limited infrastructure, where physical access to markets is so costly that households must undertake nonfarming activities to satisfy their needs for some products and services (Barrett et al., 2001).

The logic of the development of agriculture works in the opposite direction, when growing agriculture acts as a "motor" of growth for nonfarm activities through production and consumption linkages (Haggblade \& Hazell, 1989; Mellor, 1995). A growing farm sector implies an increase in the demand for inputs and services and the resulting higher incomes generate higher demand for 
nonfarm consumer goods. This may stimulate the local nonfarm sector, which in turn may "pull" people out of agriculture.

Agriculture is not the only potential growth "motor" for the RNFE. Tourism or mining can also facilitate development of nonfarm activities (Reardon et al., 2001). Proximity to urban centres can open new opportunities for rural nonfarm activities as well, as they may serve as a market for goods or services produced in rural areas. On the other hand, cities can also expose rural producers to threats like quality requirements and a more competitive environment (Islam, 1997).

It is important to mention that in the long run, the relationship between agricultural productivity and nonfarm employment may become more complicated. Foster and Rosenzweig (2004) hypothesise that agricultural productivity first drives up both farm and nonfarm wages, but later on rural factories reallocate from high-wage to low-wage villages. They used panel data from Indian villages to show how growth in agricultural income can led to decline in rural manufacturing.

As indicated, incentives are not the only factors shaping the RNFE; the capacity to engage in RNFE is important as well. Education can for example help to undertake nonfarm activities that require special skills and knowledge. Similarly, having access to credit can help to overcome financial barriers to setting up new businesses or expanding existing ones.

Importantly, many factors affect both the incentives and the capacity to engage in the RNFE. An imperfect credit market may explain why a farmer needs to do nonfarming to earn cash to invest in his farm, but it may also inhibit diversification into nonfarm activities with high capital requirements. Imperfect land markets may lead to similar problems. Therefore, in resource-poor regions, where there are stronger incentives to start nonfarm activities, there is often no supportive capacity to do so at the meso level (Reardon et al., 2006).

\subsection{THE RNFE IN KYRGYZSTAN}

\subsubsection{Data description}

The data used for the analysis are part of three representative household budget surveys (HBS), conducted by the National Statistical Committee (NSC) of the Kyrgyz Republic in 2003, 2005, and 2006. Only rural households are taken for the analysis, accounting for about 1800 observations for each year. The use of individual and household weights ensures representativeness of the obtained results at the country and regional levels. We mostly use two sections from the survey, which was administrated quarterly: a section about employment at the level of the individual and a section containing detailed household-level 
information on expenditures for and income from production and processing of crops and livestock.

The HBS considers an individual to be employed if he or she was engaged in income generating activities for at least one hour in the week before the survey. Employment is categorised into primary, secondary and tertiary employment based on time spent: the activity that takes up most of the time of an individual is his/her primary employment; the activity that takes up the second-most time is his/her secondary employment; tertiary employment is residual employment in addition to the main and secondary job. It is relatively rare and mostly involves work on subsidiary plot or processing of farm products. For each employment category, the data provide information on the hours worked in the week before the survey, the sector of employment, and whether it involved wage or selfemployment for 2005 and 2006. The employment section also includes income in the month before the survey for all activities but farm self-employment. ${ }^{21}$ Income was registered separately only for primary employment and additional employment, which includes both secondary and tertiary employment.

We computed nonfarm income as the sum of income from all (primary and additional) nonfarm jobs of the different household members. We include only earned income, as we are interested in nonfarm employment and the incomes associated with this. We decided to leave out income from the processing of farm products since virtually all rural households used processed products just for home consumption.

Total income is the sum of nonfarm income, farm income, and unearned income from scholarships, interest incomes, social benefits, and net transfers. We calculated farm income as the sum of aggregate farm wages for all household members and income from the peasant farm or subsidiary plot, which includes net income from crops and animals. Net crop income is obtained by subtracting gross costs from the volume harvested times median sales prices at the regional level. Livestock income consists of net income from sold live animals and raw animal products, such as meat, eggs, milk, skin and so forth. Net income is obtained by subtracting gross production expenditure from the quantity of sold animals times median producer prices and the quantity of produced raw animal products times median consumer prices in the relevant region.

We conducted a descriptive analysis of the RNFE at regional and country levels by aggregating individual and household data. Since aggregation at the regional level does not give us sufficient degrees of freedom to estimate a regression equation, the analysis is done one level lower at the rayon (district)

\footnotetext{
${ }^{21}$ For some individuals, farm self-employment was reported. We suspect that this is erroneous double counting and do not use these data. The impact of this choice on our results is minimal: we redid our tables adding the farm self-employment income entries to total farm income and the results hardly changed.
} 
level. Similar to the aggregation for the descriptive analysis, we aggregate individual and household information at the rayon level by using mean values. To increase further the degrees of freedom of the regression, we pooled aggregated rayon information from the three survey years into one larger sample providing us with 119 observations of rayons from rural areas. The number of observations at the individual and household level is presented in table 3.2.

Table 3.2. The number of rural observations and the number of rayons by regions in 2003, 2005, 2006 used in the analysis

\begin{tabular}{lccccccc}
\hline & \multicolumn{3}{c}{$\begin{array}{c}\text { Number of rural } \\
\text { households }\end{array}$} & \multicolumn{3}{c}{$\begin{array}{c}\text { Number of locally working } \\
\text { rural individuals older than 15 }\end{array}$} & $\begin{array}{c}\text { Number } \\
\text { of } \\
\text { Regions }\end{array}$ \\
\cline { 2 - 7 } Issykkul & 2003 & 2005 & 2006 & 2003 & 2005 & 2006 & rayons \\
\cline { 2 - 7 } Jalalabat & 264 & 255 & 261 & 2059 & 1839 & 2154 & 5 \\
Naryn & 248 & 236 & 241 & 2026 & 1859 & 2094 & $8(7)^{\mathrm{a}}$ \\
Batken & 238 & 234 & 260 & 2063 & 1749 & 1684 & 5 \\
Osh & 250 & 242 & 251 & 2046 & 1779 & 1814 & 7 \\
Talas & 263 & 262 & 264 & 2243 & 1978 & 2148 & 4 \\
Chui & 351 & 382 & 374 & 2052 & 1925 & 2277 & 8 \\
Republic, rural & 1871 & 1844 & 1888 & 14154 & 12705 & 13766 & $40(39)$ \\
areas & & & & & & & \\
Republic, total & 4760 & 4771 & 4863 & 29690 & 27256 & 29652 & 40 \\
\hline
\end{tabular}

Source: National Statistical Committee, authors' calculation.

Notes: one rayon was missing in 2003 resulting in 39 rayons in this year.

\subsubsection{Magnitude, structure and dynamics of the RNFE during 2003, 2005 and 2006}

As shown in table 3.3, the share of people employed in the nonfarm sector as a primary occupation expanded from $34.3 \%$ in 2003 to $39.6 \%$ in 2006 . The share of hours worked in nonfarm activities demonstrates the same tendency. It increased from $38 \%$ in 2003 to $50 \%$ in 2006 . The expansion of the RNFE coincided with accelerating migration: the share of migrants to the total number employed increased from $4.3 \%$ in 2003 to $11.2 \%$ in 2006. Increase in the share of hours worked in the RNFE was driven by increase in absolute amount of time in the RNFE and decrease in absolute amount of time worked in farming. The highest shares of time in nonfarm activities were observed in Chui region and the southern regions: Osh, Batken and Jalalabat. Interestingly, these regions have the highest (Chui) and lowest land per capita (Osh, Batken and Jalalabat), which seems to suggest a Ushaped relationship between land and engagement in the RNFE.

The structural distribution of nonfarm employment shows that in $200357 \%$ of primary employment in the RNFE was generated in commercial nonfarm sectors. The most important commercial sectors were trade (20\%), construction, processing, transport and communications (about 9\% each). For public 
employment, education played the leading role contributing $23 \%$ to total nonfarm employment. Secondary and tertiary nonfarm employment mostly consisted of processing, construction and trade activities. The structural distribution of nonfarm employment changed between 2003 and 2006. The share of commercial nonfarm sectors increased from $57 \%$ to $65 \%$, mainly due to larger employment in construction and processing. This happened because the absolute amount of hours in commercial nonfarming increased against a stable decreasing trend in hours spent in public nonfarm employment.

Table 3.3. Share of rural people employed in nonfarm activities and share of time in nonfarm activities in rural areas, $\%$

\begin{tabular}{lccc}
\hline & 2003 & 2005 & 2006 \\
\hline \multicolumn{3}{c}{ People in nonfarm employment/all people employed (\%) } \\
\hline Main employment & $34.3 \%$ & $37.8 \%$ & $39.6 \%$ \\
Secondary employment & $1.7 \%$ & $2.7 \%$ & $2.2 \%$ \\
Tertiary employment & $0.3 \%$ & $0.2 \%$ & $0.1 \%$ \\
\hline \multicolumn{4}{c}{ Time in nonfarm activities/total time worked $(\%)$} \\
\hline Republic, rural & $38 \%$ & $46 \%$ & $50 \%$ \\
Issykkul & $30 \%$ & $35 \%$ & $34 \%$ \\
Jalalabat & $34 \%$ & $42 \%$ & $49 \%$ \\
Naryn & $23 \%$ & $27 \%$ & $38 \%$ \\
Batken & $49 \%$ & $44 \%$ & $51 \%$ \\
Osh & $39 \%$ & $49 \%$ & $54 \%$ \\
Talas & $23 \%$ & $29 \%$ & $29 \%$ \\
Chui & $52 \%$ & $63 \%$ & $61 \%$ \\
\hline
\end{tabular}

Source: NSC and authors' estimation.

Notes: indicators are obtained by summing individual data on employment status and time worked during the week at the regional and country levels.

The intensity of nonfarm activities is measured by average hours of work that an individual was employed during a week. Table 3.4 presents the data at quarterly basis to show seasonality. There was a significant difference between the intensity of employment in the nonfarm and farm sector. Primary nonfarm employment provided a full workload of 8 hours per day ( 5 working days per week) because large part of it was formal employment in enterprises and organisations. In contrast, primary farm employment revealed underemployment and substantial seasonal variation. Secondary employment in the RNFE did not generate a full workload and showed an erratic seasonal pattern. This suggests a limited possibility of secondary employment to smooth labour supply in lean agricultural seasons. 
Table 3.4. Mean weakly hours of workload in rural farm and nonfarm sectors, primary and secondary occupations

\begin{tabular}{lcccccc|cccccc}
\hline \multicolumn{4}{c|}{$\begin{array}{c}\text { Mean weekly hours of work, primary } \\
\text { employment }\end{array}$} & \multicolumn{5}{c}{$\begin{array}{c}\text { Mean weekly hours of work, } \\
\text { secondary employment }\end{array}$} \\
\hline \multicolumn{4}{c}{} & 2003 & \multicolumn{2}{c}{2005} & 2006 & \multicolumn{2}{c}{2003} & \multicolumn{2}{c}{2005} & 2006 \\
\hline Year & F & NF & F & NF & F & NF & F & NF & F & NF & F & NF \\
I & 29 & 21 & 38 & 19 & 38 & 18 & 23 & 14 & 27 & 15 & 28 \\
II & 34 & 40 & 28 & 38 & 25 & 38 & 18 & 23 & 14 & 28 & 15 & 26 \\
III & 33 & 40 & 27 & 39 & 26 & 38 & 18 & 25 & 14 & 27 & 14 & 30 \\
IV & 15 & 40 & 11 & 38 & 15 & 38 & 19 & 29 & 13 & 28 & 14 & 25 \\
\hline
\end{tabular}

Source: NSC, authors' calculation.

Notes: mean hours are calculated by aggregating quarterly individual information at the country level.

Mean regional and country shares of nonfarm income in total income followed the employment pattern and demonstrated the same positive dynamic: they increased from $31 \%$ in 2005 to $39 \%$ in 2006. The largest shares of nonfarm income were again observed in the regions with the lowest (Osh and Jalalabat) and the highest amount of land per capita (Chui) (see Figure 3.1).

Figure 3.1. Mean shares of nonfarm income in total income in rural areas, $\%$

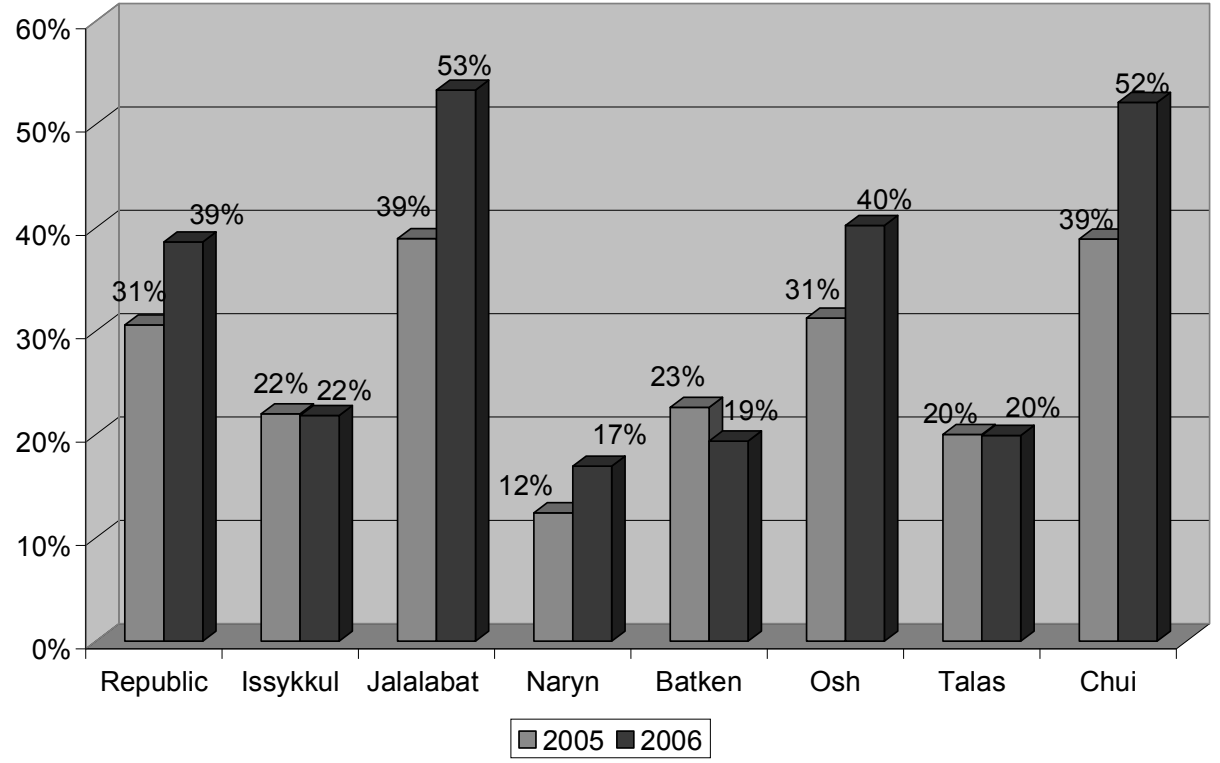

Source: NSC, authors' calculation.

Notes: mean shares are estimated by aggregating mean shares of nonfarm income at the household level. 
Breaking down nonfarm income by a functional classification of income sources also provides interesting information (table 3.5). Most primary nonfarm income was in the form of salaries: $61 \%$ (33\% commercial and 28\% public) and 65\% (40\% commercial and 25\% public) in 2005 and 2006 respectively. The highest shares of nonfarm income from salary were observed in Chui, Naryn, Talas and Issykkul. The regions with the highest share of salary from commercial nonfarm activities (Chui, Issykkul and Talas) also had the largest shares of individuals with higher and vocational education (see table 2.1 in chapter 2).

Nonfarm self-employment income represented the second largest source of total nonfarm income, accounting for $29 \%$ in both years. Among leaders in this source of nonfarm income were regions with the lowest per capita land sizes (Jalalabat, Osh and Batken). Additional nonfarm income was in the third place, decreasing from $9 \%$ in 2005 to $6 \%$ in 2006. Again, the leaders in this source of nonfarm income were regions with the lowest size of land per capita.

Table 3.5. Regional structure of rural nonfarm income by functional classification of income in 2005 and 2006, \%

\begin{tabular}{|c|c|c|c|c|c|c|c|c|c|}
\hline & \multicolumn{2}{|l|}{2005} & \multicolumn{2}{|l|}{2006} & 2005 & 2006 & 2005 & 2006 & $\begin{array}{c}2005 / 20 \\
06\end{array}$ \\
\hline & \multicolumn{4}{|c|}{ Salary } & \multirow{2}{*}{\multicolumn{2}{|c|}{$\begin{array}{c}\text { Self- } \\
\text { employment }\end{array}$}} & \multirow{2}{*}{\multicolumn{2}{|c|}{$\begin{array}{l}\text { Additional } \\
\text { income }\end{array}$}} & \multirow{2}{*}{ Total } \\
\hline & commercial & public & commercial & public & & & & & \\
\hline Issykkul & $61 \%$ & $23 \%$ & $60 \%$ & $29 \%$ & $11 \%$ & $11 \%$ & $6 \%$ & $0 \%$ & $100 \%$ \\
\hline Jalalabc & $\%$ & $25 \%$ & $31 \%$ & $27 \%$ & $36 \%$ & $34 \%$ & $12 \%$ & $8 \%$ & $100 \%$ \\
\hline Naryn & $15 \%$ & $68 \%$ & $15 \%$ & $59 \%$ & $10 \%$ & $24 \%$ & $7 \%$ & $2 \%$ & $100 \%$ \\
\hline Batken & $26 \%$ & $37 \%$ & $28 \%$ & $40 \%$ & $35 \%$ & $32 \%$ & $1 \%$ & $0 \%$ & $100 \%$ \\
\hline Osh & $1 \%$ & $27 \%$ & $31 \%$ & $22 \%$ & $34 \%$ & $36 \%$ & $18 \%$ & $10 \%$ & $100 \%$ \\
\hline Talas & $44 \%$ & $34 \%$ & $39 \%$ & $41 \%$ & $22 \%$ & $20 \%$ & $1 \%$ & $1 \%$ & $100 \%$ \\
\hline Chui & $52 \%$ & $20 \%$ & $65 \%$ & $10 \%$ & $27 \%$ & $21 \%$ & $1 \%$ & $4 \%$ & $100 \%$ \\
\hline Republic & $33 \%$ & $28 \%$ & $40 \%$ & $25 \%$ & $29 \%$ & $29 \%$ & $9 \%$ & $6 \%$ & $100 \%$ \\
\hline
\end{tabular}

Source: National Statistical Committee, authors' calculation.

Note: households with zero nonfarm income are excluded from calculation. Mean values of shares of different nonfarm income sources in total nonfarm income at the household level are used to estimate shares in the table.

Summing up, nonfarm activities played an important role in the Kyrgyz Republic in the period considered. Both the magnitude and the intensity of nonfarm activities have expanded since 2003. Income from salary was the most important source of nonfarm income, and its role was increasing with time due to commercial nonfarm activities. Nonfarm employment and nonfarm income were most prominent in regions with either the largest (Chui) or the lowest (Osh and Jalalabat) per capita land sizes. This is in line with predictions from "pull" and "push" scenarios behind development of the RNFE discussed in the theoretical 
section 3.2.2 and may indicate that the magnitude of nonfarm activities depends on the regional agricultural potential. This will be formally tested in next section.

\subsection{RNFE DETERMINANTS AT THE RAYON LEVEL}

\subsubsection{Model specification}

We use a simple empirical model to explain the magnitude of the RNFE in different rayons of the Kyrgyz Republic. The dependent variable is percentage of time in nonfarm activities to total time worked at the rayon level. We ran separate regressions for percentage of time in commercial, public and total time in nonfarm activities. The discussion of the results will focus on the regression for the commercial RNFE, since the commercial sector provides most nonfarm employment and is shaped mostly by private decisions with only indirect influence of government policy.

Following the theoretical overview, the explanatory variables represent factors that affect the incentives and capacity of the rural population to engage in the RNFE and, as a result, shape the magnitude of commercial nonfarm activities at the rayon level. We measure incentives by agricultural potential and the presence of other "local" engines of growth. As indicator of capacity, we included a human capital variable. We also included indicators for geography and infrastructure, which affect both capacity and incentives. Finally, we included regional dummies (Chui region is the base) and dummies for 2005 and 2006 to control for region and year effects.

We employ two indicators to measure agricultural potential in the rayon. The first is the average size of agricultural land per capita. For reasons of accuracy, we decided to take information on land size from the State Register of the Kyrgyz Republic instead of the survey. As the State Register does not provide information on the size of land for the years of the survey, we took total agricultural land per rayon at the end of 2008 and divided it by the size of the rural rayon population in 2003, 2005 and 2006 to get agricultural land per capita. Agricultural land includes arable land, fallow land, perennials and hayfield. Unfortunately, we do not have information on the size of public pastures. ${ }^{22}$ We hypothesize that in areas with limited availability of land, nonfarm employment will be high because households are pushed to the RNFE, while in rayons with ample land, agricultural development may stimulate nonfarm activities, which pull households to the RNFE. To account for this possible U-shaped relationship between land per capita and share of time in the RNFE, we also include the square of land per capita.

The second indicator for agricultural potential measures the quality of land and its harvesting capacity. For this purpose we employ rayon-level basic rates for

${ }^{22}$ Geography dummies described further in the text can partially substitute this variable. 
land tax in 2002.23 The government of the Kyrgyz Republic establishes land tax rates dependent on the fertility and location of land. Since basic rates are different for different type of land, we constructed a weighted average of tax rates using the shares of each type of land as weights. We hypothesise that the size and the quality of land may complement each other in determining the development of agriculture in the rayons, which, in turn, affects the magnitude of the RNFE. We therefore included an interaction term of land size per capita and land tax.

To control for local engines of growth other than agriculture, we introduce a dummy for the rayon where famous resort area Issyk-Kul is located. In addition, we include a dummy for the presence of towns in rayons and a variable measuring the distance from rayon centres to the regional capitals in kilometres. We hypothesise that having a town as a rayon centre and being closer to the regional capital can indicate the presents of markets and employment centres for rural households. Finally, we include the rural and urban population size of the rayon as a proxy for local market size which can also stimulate development of nonfarm activities.

To account for differences in capacity between rayons, we include a variable measuring human capital: the share of employed individuals with higher and vocational education in the total number of locally employed rural inhabitants. We expect to find a strong positive impact of this variable on the share of nonfarm activities in total employment.

Geography is measured by two dummy variables. The survey classifies rayons into high-mountain, medium-mountain and flat areas. Since high-mountain regions are characterised by remoteness from roads, lack of infrastructure and unfavourable climate conditions (UNDP, 2002), these factors can stimulate nonfarm activities as an alternative to agriculture, but can also highly constrain them affecting negatively the capacity of rural inhabitants to participate in the RNFE. In contrast, there are weaker incentives to undertake nonfarm activities in flat areas due to more favourable agricultural conditions, but better capacity to do so. We therefore include dummy variables for flat and high-mountain areas in the regression. The signs of the coefficients cannot be predicted a priori.

We measure development of infrastructure by two additional variables: the average time required to get to the bus stop and the percentage of people with access to clean water. The average time to get to the bus is estimated in two steps. First, we calculated the shares of households for each particular time group $(5,10$, 20, 45, 95 minutes to bus-stop). Second, we multiply these shares with the indicated times to compute the weighted average. Access to water via infrastructure is

\footnotetext{
${ }^{23}$ One may argue that tax may have negative impact on agriculture reducing incentives of farmers. However, according to the survey of farmers, they considered the size of land tax fair and were even ready to pay higher rates (USAID, 2008). Therefore, we assume land taxes do not distort the incentives of farmers.
} 
measured as the mean percentage of rayon households with access to water through a home water pipe, well or water pump. We expect development of infrastructure to contribute positively to nonfarm employment by lowering costs, although, on the other hand, road infrastructure can also lead to stronger competition from the outside world.

\subsubsection{Empirical results}

Descriptive statistics and regression results (coefficients and robust standard errors) are presented in tables 3.6 and 3.7. Comparison of the results for the three different dependent variables -share of time in commercial, public, and all nonfarm employment- supports our decision to analyse commercial nonfarm activities separately from public nonfarm activities. ${ }^{24}$ The regression results for the two types of activities are completely different, showing that indeed these two types of the RNFE have different driving factors and should be modelled separately. As our framework was developed for commercial activities, we focus our discussion on the associated regression.

The results provide support for the "push" hypothesis, which suggests that people move into the RNFE because of lack of other options. Agricultural land per capita had a significant negative effect on the share of time spent in the RNFE, indicating that in areas with a high population pressure labour is "pushed" into the nonfarm sector. The land quality indicators and the distance from regional centres confirm this story. In remote and depressed areas with low quality of land (as indicated by a low average land tax) the share of time spent in commercial nonfarm activities is higher since agricultural activities are not sufficient to provide means for sustainable living.

Besides "push" factors, we also found evidence of "pull" factors. Firstly, the coefficient for the squared term of land size is significant and positive. This implies that in areas with increasingly higher land availability per capita, the magnitude of the RNFE decreases at an ever slower rate and ultimately even increases. We present a simple simulation to illustrate this finding further on in the text. Secondly, the interaction term of land size per capita and land tax is positive and significant, indicating that more land combined with higher quality stimulates employment in the RNFE. Thirdly, flat rayons with more favourable agricultural conditions exhibit higher shares of time in nonfarming, suggesting that dynamic agriculture and good infrastructure create opportunities in the RNFE. Finally, the positive and significant coefficient for the resort dummy supports the hypothesis

\footnotetext{
${ }^{24}$ In order to test the robustness of the obtained results, we run regressions with the same specification for percentage of people employed in primary nonfarm activities to the total number of employed rural inhabitants. Results are presented in the annex and they are robust.
} 
that nonfarm activities can be also stimulated by other "motors" of growth than agriculture.

Table 3.6. Descriptive statistics, 2003, 2005 and 2006 years

\begin{tabular}{|c|c|c|c|c|c|}
\hline Variables & Obs & Mean & Std. Dev. & Min & Max \\
\hline $\begin{array}{l}\text { Share of time in total nonfarm } \\
\text { employment }\end{array}$ & 119 & 0.42 & 0.20 & 0.10 & 0.98 \\
\hline $\begin{array}{l}\text { Share of time in public nonfarm } \\
\text { employment }\end{array}$ & 119 & 0.15 & 0.09 & 0.00 & 0.42 \\
\hline $\begin{array}{l}\text { Share of time in commercial } \\
\text { nonfarm employment }\end{array}$ & 119 & 0.27 & 0.18 & 0.01 & 0.82 \\
\hline $\begin{array}{l}\text { Share of nonfarm employment in } \\
\text { total employment }\end{array}$ & 119 & 0.38 & 0.20 & 0.07 & 0.97 \\
\hline $\begin{array}{l}\text { Share of public nonfarm } \\
\text { employment in total employment }\end{array}$ & 119 & 0.16 & 0.10 & 0.00 & 0.49 \\
\hline $\begin{array}{l}\text { Share of commercial nonfarm } \\
\text { employment in total employment }\end{array}$ & 119 & 0.22 & 0.18 & 0.01 & 0.83 \\
\hline Weighted average of land tax, som & 119 & 264.2 & 90.7 & 99.6 & 390.9 \\
\hline Agricultural land per capita, ha & 119 & 0.4 & 0.2 & 0.1 & 1.2 \\
\hline Average time to bus-stop, minutes & 119 & 13.6 & 5.5 & 5.8 & 48.5 \\
\hline $\begin{array}{l}\% \text { of the population with access to } \\
\text { water via infrastructure (pump, } \\
\text { pipe) }\end{array}$ & 119 & 34.1 & 33.1 & 0 & 100 \\
\hline $\begin{array}{l}\text { Share of individuals with higher } \\
\text { and vocational education among } \\
\text { employed rural population, } \%\end{array}$ & 119 & 35.8 & 13.7 & 6.7 & 83.5 \\
\hline $\begin{array}{l}\text { Dummy for resort area in Issyk-Kul } \\
\text { region }\end{array}$ & 119 & 0.03 & 0.16 & 0 & 1 \\
\hline Dummy for rayons with cities & 119 & 0.33 & 0.47 & 0 & 1 \\
\hline $\begin{array}{l}\text { Distance from rayon centres to } \\
\text { provincial centres, } \mathrm{km}\end{array}$ & 119 & 61.5 & 47 & 0 & 180 \\
\hline Dummy for flat rayons & 119 & 0.6 & 0.5 & 0 & 1 \\
\hline Dummy for high-mountain rayons & 119 & 0.2 & 0.4 & 0 & 1 \\
\hline Rural population size, thousand & 119 & 80.89 & 57.05 & 12.3 & 303.2 \\
\hline Urban population size, thousand & 119 & 7.44 & 11.6 & 0 & 48.2 \\
\hline
\end{tabular}

Source: authors' calculation.

As hypothesised, we found that human capital and access to infrastructure were important for the development of commercial nonfarm activities. A higher stock of human capital enables rural inhabitants to overcome skill-based barriers to entry the RNFE, and a higher level of public services and infrastructure - as indicated by better access to water infrastructure - will reduce the costs of participating in markets irrespective of whether nonfarm activities driven by "push" or "pull" factors (see table A3.1 in the Annex 3.6). Larger market capacity, measured by the size of rural population, is found to have positive impact on nonfarming. 
In order to illustrate our findings and test whether "push" or "pull" factors were most relevant for the development of the RNFE in Kyrgyzstan, figure 3.2 presents simulations of the combined impact of land and its quality on the share of time in commercial nonfarm employment. The starting points are rayons with 0.3 hectares of total land per capita of different quality (land tax 250, 300, 320, 350 and 390 som per hectare). For each of the rayons, we estimated the change in the share of time in commercial nonfarm activities in total time worked for increases of arable land in steps of 0.1 hectare. Note that the mean size of land per capita in the Republic was 0.4 ha with a mean tax rate of 264 som.

Table 3.7. OLS regressions of the share of time in nonfarm employment (pooled sample for 2003, 2005 and 2006, $N=119$ )

\begin{tabular}{|c|c|c|c|}
\hline \multirow[b]{2}{*}{ Explanatory /dependent variables } & 1 & 2 & 3 \\
\hline & $\begin{array}{c}\text { Commercial } \\
\text { nonfarm } \\
\text { employment }\end{array}$ & $\begin{array}{c}\text { Public } \\
\text { nonfarm } \\
\text { employment }\end{array}$ & $\begin{array}{c}\text { Total nonfarm } \\
\text { employment }\end{array}$ \\
\hline \multirow[t]{2}{*}{ Total land per capita, ha } & $-1.553^{* * *}$ & $0.928^{* * *}$ & -0.625 \\
\hline & [0.446] & {$[0.272]$} & [0.556] \\
\hline \multirow[t]{2}{*}{ Total land per capita, squared ha } & $0.714^{* * *}$ & $-0.238^{*}$ & $0.476^{*}$ \\
\hline & [0.229] & {$[0.126]$} & {$[0.276]$} \\
\hline \multirow[t]{2}{*}{ Land per capita* size of the land tax } & $0.00207^{* *}$ & $-0.00195^{* * *}$ & 0.000124 \\
\hline & {$[0.000808]$} & {$[0.000481]$} & [0.000927] \\
\hline \multirow{2}{*}{$\begin{array}{l}\text { Weighted average size of the land tax, } \\
\text { som }\end{array}$} & $-0.00110^{* * *}$ & 0.000225 & $-0.000878^{* *}$ \\
\hline & {$[0.000337]$} & [0.000209] & {$[0.000402]$} \\
\hline \multirow[t]{2}{*}{ Average time to bus-stop, minutes } & -0.000277 & 0.00155 & 0.00126 \\
\hline & [0.00257] & {$[0.00208]$} & {$[0.00220]$} \\
\hline \multirow{2}{*}{$\begin{array}{l}\% \text { of the population having access to } \\
\text { water via infrastructure (pump, pipe) }\end{array}$} & 0.000452 & 0.00233 & 0.00277 \\
\hline & [0.00259] & {$[0.00201]$} & {$[0.00218]$} \\
\hline \multirow[t]{2}{*}{ Dummy for resort area in Issykkul region } & $0.00172^{* *}$ & 0.000126 & $0.00184^{* *}$ \\
\hline & [0.000727] & {$[0.000263]$} & {$[0.000760]$} \\
\hline \multirow[t]{2}{*}{ Dummy for flat rayons } & $0.109^{* *}$ & 0.0369 & $0.147^{* * *}$ \\
\hline & [0.0445] & {$[0.0230]$} & [0.0499] \\
\hline \multirow[t]{2}{*}{ Dummy for high-mountain rayons } & 0.0805 & -0.0749 & 0.00551 \\
\hline & {$[0.0771]$} & {$[0.0685]$} & [0.109] \\
\hline \multirow[t]{2}{*}{ Dummy for rayons with cities } & -0.0395 & -0.00301 & -0.0427 \\
\hline & [0.0293] & [0.0147] & {$[0.0315]$} \\
\hline \multirow{2}{*}{$\begin{array}{l}\text { Distance from rayon centres to provincial } \\
\text { centres, } \mathrm{km}\end{array}$} & $0.000821^{* * *}$ & 0.000367 & $0.00119^{* * *}$ \\
\hline & {$[0.000311]$} & [0.000235] & {$[0.000380]$} \\
\hline \multirow[t]{2}{*}{ Urban population size, thou. } & -0.0018 & $-0.00245^{* * *}$ & $-0.00424^{* * *}$ \\
\hline & {$[0.00136]$} & {$[0.000722]$} & [0.00155] \\
\hline \multirow[t]{2}{*}{ Rural population size, thou. } & $0.000910^{* *}$ & -0.000259 & 0.00065 \\
\hline & [0.000415] & [0.000203] & [0.000473] \\
\hline \multirow{2}{*}{$\begin{array}{l}\text { Share of individuals with higher and } \\
\text { vocational education among employed } \\
\text { rural population }\end{array}$} & $0.00336^{* * *}$ & $0.00198^{* * *}$ & $0.00534^{* * *}$ \\
\hline & {$[0.00105]$} & {$[0.000471]$} & {$[0.00112]$} \\
\hline
\end{tabular}




\begin{tabular}{lccc}
\hline & 1 & 2 & 3 \\
\cline { 2 - 4 } Explanatory /dependent variables & $\begin{array}{c}\text { Commercial } \\
\text { nonfarm } \\
\text { employment }\end{array}$ & $\begin{array}{c}\text { Public } \\
\text { nonfarm } \\
\text { employment }\end{array}$ & $\begin{array}{c}\text { Total nonfarm } \\
\text { employment }\end{array}$ \\
\hline Constant & $\begin{array}{c}0.527^{* * *} \\
{[0.171]}\end{array}$ & $\begin{array}{c}-0.131 \\
{[0.102]}\end{array}$ & $0.397^{*}$ \\
\hline R-squared & 0.722 & 0.539 & 0.646 \\
\hline
\end{tabular}

Notes: ${ }^{* *} \mathrm{p}<0.01,{ }^{* *} \mathrm{p}<0.05,{ }^{*} \mathrm{p}<0.1$ Year and regional dummies are not reported. Robust standard errors are in parentheses.

The figure demonstrates that all curves have a U-shape with the parts of the curves below the x-axis of $0 \%$ reflecting "push" and parts above the $\mathrm{x}$-axis reflecting "pull" scenarios. Increasing the availability of land would lead to a decrease in the share of commercial nonfarm time on the "push" part, while on the "pull" part the share of commercial nonfarm time increases with land availability. Curves based on higher quality of land have the switch point at lower land sizes meaning that less land is needed for agriculture to become a driving force for a profitable nonfarm economy when the quality of land is higher.

If, for instance, we increase the size of land of average quality 250 som from the value of $0.3 \mathrm{ha}$, this will result in a decrease of the nonfarm time share at an accelerating rate, but after reaching 0.8 ha the negative effect starts to decrease. At about 1.2 ha, the effect of an additional increase in land size would become positive. For land of very high quality, 390 som per ha, a land size of just over 0.9 ha is already sufficient for agriculture to have a positive impact on the development of the RNFE. Such a situation is, however, an exceptional situation in Kyrgyzstan: only two rayons have an average size of arable land of about 0.9 ha with a quality close to 390 . 
Figure 3.2. Simulation of the change in share of time worked in commercial nonfarm employment to total worked time after increase of total land for different levels of quality, $\%$

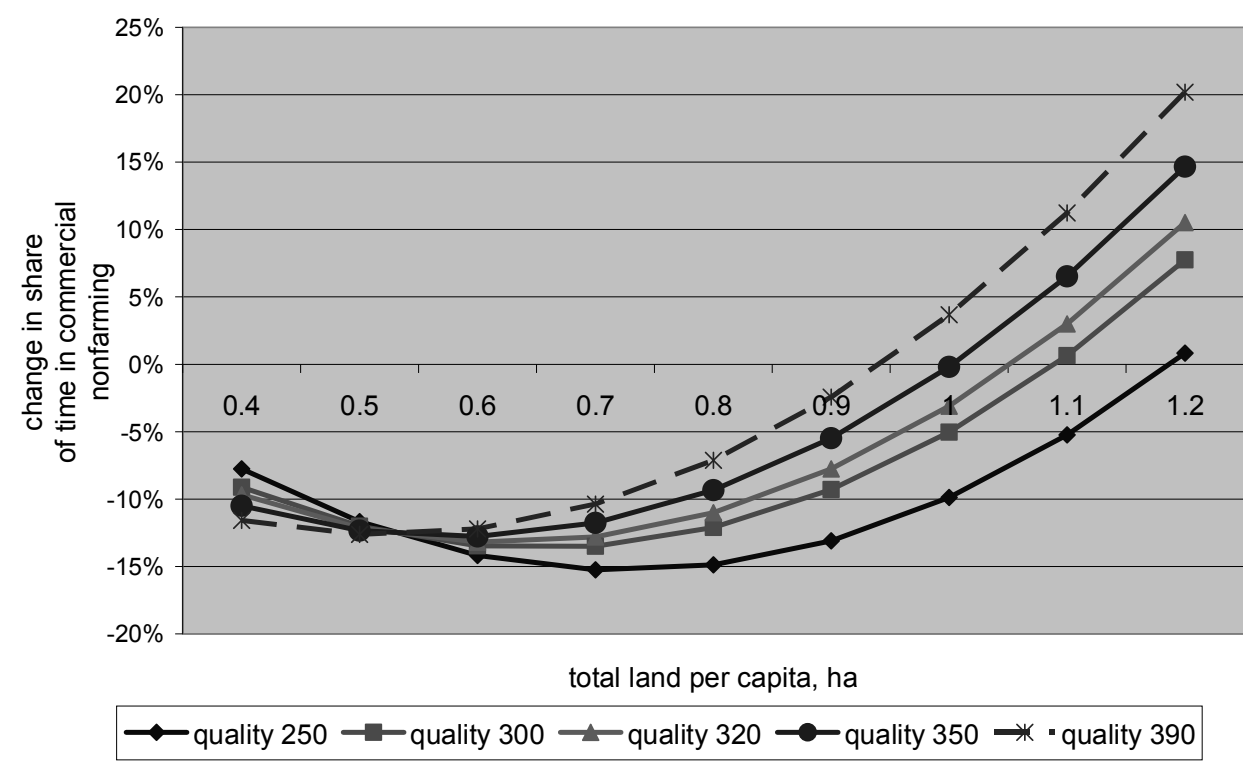

Source: authors' estimation.

In sum, empirical analysis reveals that participation in the commercial RNFE in Kyrgyzstan is mainly driven by "push" factors, namely high pressure on land and its poor quality. Only in a few resource-rich rayons with favourable agricultural conditions and low population pressure and in a resort area, can nonfarm employment be attributed to "pull" factors. This indicates that the current level of development with semi-subsistence agriculture on small farms constrained by market imperfections is not conducive to the creation and expansion of a profitable rural nonfarm economy. Nevertheless, the role of the RNFE in Kyrgyzstan both for employment and rural income is substantial, since nonfarm activities compensate for the lack of opportunities in farming and are accessible for poor rural households with lack of land.

\subsection{CONCLUSION}

Analysis of nonfarm activities in the Kyrgyz Republic based on three representative household budget surveys reveals that the RNFE played a substantial role in the economy, accounting for $50 \%$ of total time worked in rural areas in 2006. It has expanded significantly since 2003 in the context of slowing agricultural growth, higher population pressure on land and accelerating international labour migration. The increasing share of nonfarm income from $31 \%$ 
in 2005 to $39 \%$ in 2006 also indicates its importance for the wellbeing of rural households.

Nonfarm activities are particularly important in the regions with the lowest land per capita (Osh and Jalalabat) and in the region with the largest land per capita (Chui). The sectors providing most nonfarm employment are education, health, trade, construction and transport. The most important source of nonfarm income is salaried jobs, especially in the areas with higher human capital stock, followed by self-employment. Primary nonfarm employment provides a fulltime workload and involves mainly wage employment in organisations, firms and so forth. Secondary nonfarm employment is relatively unimportant and mostly consists of self-employment or working for private individuals. Its seasonal pattern is erratic, which suggest a limited potential to use the RNFE to smooth labour supply in the lean agricultural seasons.

Regression analysis of commercial nonfarm employment at rayon level demonstrates that the size of agricultural land per capita and land quality are crucial factors for explaining the magnitude of nonfarm activities. In most areas, land is scarce and of poor quality and people are "pushed" into nonfarming, while in the very few areas with an abundance of land of high quality, in contrast, people are "pulled" into the RNFE. The prevalence of the "push" scenario can also be related to the low commercialisation and subsistence orientation of the Kyrgyz agriculture that persists even though agriculture was the engine of growth during the second half of the 1990s.

The strong negative ties between the RNFE and the size and quality of land imply that nonfarm activities are relatively accessible to the poor, although they do not necessarily generate high returns. This is an important finding, since international labour migration, the main other alternative to farm work, often excludes the poorest households. Ability of rural poor to participate in nonfarm activities can be explained by relatively low entrance barriers of nonfarm activities, but possibly also by massive development aid targeted at the development of rural infrastructure, facilitating access to microfinance, and providing advisory and other farm services.

The predominant "push" nature of the RNFE indicates that the current state of agriculture is not conducive to the development of nonfarm activities with higher returns. Under these circumstances, besides stimulating agricultural development per se, it is important to identify and focus on general factors affecting profitability and expansion of the current rural nonfarm activities, especially in areas where the capacity of agriculture is constrained by the natural environment. Only in the few areas with very favourable agricultural circumstances or with resorts, specific policies to increase access of the poor to profitable nonfarm activities are useful. Finally, since development of nonfarm activities is facilitated by investment in education and infrastructure this should be taken into account in designing rural policies in the Kyrgyz Republic. 


\subsection{ANNEX}

Table A3.1. OLS regressions of the share of primary nonfarm employment in total employment at rayon level (pooled sample for 2003, 2005 and 2006, $\mathrm{N}=119$ )

\begin{tabular}{|c|c|c|c|}
\hline \multirow[b]{2}{*}{ Explanatory /dependent variables } & 1 & 2 & 3 \\
\hline & $\begin{array}{c}\text { Commercial } \\
\text { nonfarm } \\
\text { employment }\end{array}$ & $\begin{array}{c}\text { Public } \\
\text { nonfarm } \\
\text { employment }\end{array}$ & $\begin{array}{l}\text { Total nonfarm } \\
\text { employment }\end{array}$ \\
\hline \multirow[t]{2}{*}{ Total land per capita, ha } & $-1.645^{* * *}$ & $0.817^{* * *}$ & -0.839 \\
\hline & {$[0.476]$} & [0.297] & [0.643] \\
\hline \multirow[t]{2}{*}{ Total land per capita, squared ha } & $0.680^{* * *}$ & $-0.246^{*}$ & 0.443 \\
\hline & {$[0.228]$} & [0.139] & [0.306] \\
\hline \multirow[t]{2}{*}{ Land per capita* size of the land tax } & $0.00262^{* * *}$ & $-0.00156^{* * *}$ & 0.00106 \\
\hline & [0.000813] & {$[0.000472]$} & {$[0.000980]$} \\
\hline \multirow{2}{*}{$\begin{array}{l}\text { Weighted average size of the land tax, } \\
\text { som }\end{array}$} & $-0.00135^{* * *}$ & 7.81E-05 & $-0.00128^{* * *}$ \\
\hline & {$[0.000313]$} & [0.000209] & {$[0.000398]$} \\
\hline \multirow[t]{2}{*}{ Average time to bus-stop, minutes } & 0.000626 & 0.00213 & 0.00277 \\
\hline & {$[0.00260]$} & [0.00173] & [0.00243] \\
\hline \multirow{2}{*}{$\begin{array}{l}\% \text { of the population having access to } \\
\text { water via infrastructure (pump, pipe) }\end{array}$} & $0.00117^{*}$ & $3.66 \mathrm{E}-06$ & $0.00118^{*}$ \\
\hline & {$[0.000604]$} & {$[0.000279]$} & {$[0.000663]$} \\
\hline \multirow{2}{*}{$\begin{array}{l}\text { Dummy for resort area in Issykkul } \\
\text { region }\end{array}$} & $0.319^{* * *}$ & -0.0635 & $0.253^{* * *}$ \\
\hline & [0.0632] & [0.0383] & {$[0.0754]$} \\
\hline \multirow[t]{2}{*}{ Dummy for flat rayons } & 0.058 & 0.0331 & $0.0905^{*}$ \\
\hline & [0.0402] & {$[0.0233]$} & [0.0498] \\
\hline \multirow[t]{2}{*}{ Dummy for high-mountain rayons } & 0.0695 & -0.0958 & -0.0284 \\
\hline & {$[0.0740]$} & {$[0.0711]$} & [0.115] \\
\hline \multirow[t]{2}{*}{ Dummy for rayons with cities } & $-0.0451^{*}$ & -0.00331 & -0.0484 \\
\hline & {$[0.0265]$} & {$[0.0150]$} & {$[0.0322]$} \\
\hline \multirow{2}{*}{$\begin{array}{l}\text { Distance from rayon centres to } \\
\text { provincial centres, } \mathrm{km}\end{array}$} & $0.000831^{* * *}$ & 0.000394 & $0.00123^{* * *}$ \\
\hline & {$[0.000287]$} & [0.000240] & [0.000400] \\
\hline \multirow[t]{2}{*}{ Urban population size, thou. } & -0.00187 & $-0.00233^{* * *}$ & $-0.00421^{* * *}$ \\
\hline & [0.00127] & {$[0.000729]$} & {$[0.00156]$} \\
\hline \multirow[t]{2}{*}{ Rural population size, thou. } & $0.000999^{* * *}$ & $-7.98 \mathrm{E}-05$ & $0.000913^{*}$ \\
\hline & {$[0.000371]$} & {$[0.000214]$} & [0.000463] \\
\hline \multirow{2}{*}{$\begin{array}{l}\text { Share of individuals with higher and } \\
\text { vocational education among employed } \\
\text { rural population }\end{array}$} & $0.00324^{* * *}$ & $0.00352^{* * *}$ & $0.00670^{* * *}$ \\
\hline & [0.000836] & {$[0.000534]$} & {$[0.000858]$} \\
\hline R-squared & 0.75 & 0.578 & 0.655 \\
\hline
\end{tabular}

Notes: ${ }^{* * *} \mathrm{p}<0.01,{ }^{* *} \mathrm{p}<0.05,{ }^{*} \mathrm{p}<0.1$ Constant, year and regional dummies are not reported.

Robust standard errors are in parentheses. 


\section{MICROECONOMIC ANALYSIS OF RURAL NONFARM ACTIVITIES IN KYRGYZSTAN: WHAT DETERMINES PARTICIPATION AND RETURNS?25}

The rural nonfarm economy is very important for sustainable poverty reduction in post-communist Central Asia, which faces high population pressure, constrained land resources, unfinished agricultural reforms and uncertain migration prospects. This chapter uses two representative household budget surveys from Kyrgyzstan to analyse factors influencing participation and returns from different types of nonfarm activities in 2005 and 2006. Nonfarm activities were found to be most important for the poor, who are pushed out of agriculture due to limited and poor land resources. We showed that different nonfarm activities have different human capital requirements and some determinants have different impact on participation and income from nonfarm activities. Better education, access to infrastructure, and cattle ownership are found to increase nonfarm income while not necessarily related to participation in nonfarm activities. Therefore, equipping poor households to enable them to move towards better remunerative nonfarm activities should be a priority.

\footnotetext{
${ }^{25}$ This chapter is based on an article co-authored with Marrit van den Berg. It is in the revise and resubmit status with Agricultural Economics. This paper is also available as: Atamanov, A. and Van den Berg, M. (2011). Microeconomic analysis of rural nonfarm activities in the Kyrgyz Republic: What determines participation and returns? Working paper 001. Maastricht University. Maastricht Graduate School of Governance.
} 


\section{$4.1 \quad$ INTRODUCTION}

Despite economic growth and various reforms, Central Asia is still a poor and predominantly rural region. In three of the five Central Asian republics (Kyrgyzstan, Tajikistan and Uzbekistan), more than $60 \%$ of the population lived in rural areas, and agriculture provided more than $25 \%$ of national income in 2007 (FAO, 2009). In comparison, other former Soviet republics have a more urbanbased, non-agricultural economy. Poverty is mostly concentrated in rural areas in Central Asia, and throughout the region there is a need for policies to respond to this challenge.

Policy makers and the donor community increasingly acknowledge that agriculture alone is not sufficient to achieve sustainable poverty reduction in the Central Asian context of high population pressure, constrained land resources, and unfinished agricultural reforms (World Bank, 2004; Spoor, 2008; Maddock, 2009). Until recently, labour migration was a widely used income diversification strategy (see, ADB, 2008ab), but the current economic crisis makes migration prospect uncertain. In such circumstances, the rural nonfarm economy may act as a cushion, absorbing rural labour and providing an opportunity to earn money.

Empirical studies often demonstrate that the RNFE comprises a set of heterogeneous activities, ranging from employment in high productive sectors to low productive activities earning just enough to sustain subsistence (Reardon, 1997). This heterogeneity is driven by different incentives and capacity to undertake nonfarm activities among rural households. Many poor households are excluded from nonfarm activities due to the lack of assets required to overcome entrance barriers. Others are trapped in low-remunerative activities that do not allow them to grow out of poverty. Consequently, identification of the factors shaping access and income from nonfarm activities is crucial for policy makers to inform and adjust policies in the rural domain (Reardon et al., 2006). In contrast with the previous chapter which focused on the rayon level as unit of analysis, this chapter analyses the relationships at the level of the individual.

Despite the large number of studies analysing the nature and consequences of the associated agricultural reforms in the region (Lerman, 2007; Lerman \& Sedik, 2009a), there is almost complete lack of empirical evidence on the nature and drivers of the rural nonfarm economy (RNFE) in post-Soviet Central Asia. To fill this gap, this paper analyses the determinants of participation and income from nonfarm activities in Kyrgyzstan. This is the only study analysing quantitatively determinants and income from nonfarm activities in this country. Unlike other studies, in our regression analysis we control for the fact that some variables may diminish incentives to start nonfarming, but in case of participation increase nonfarm income by means of the strengthened capacity or better access to higher remunerative activities. High rural poverty, slowing agricultural growth and accelerating labour migration with uncertain prospects make this regional 
advanced agricultural reformer very interesting to study, and the results can be informative for the broader regional discussion on finding prospects to improve the livelihoods of the rural population.

The layout of this chapter is as follows. It starts from the discussion of the theory and the choice of estimation techniques. Then we describe the role of the RNFE playing in the country. Afterwards we present the results from the empirical models followed by conclusions.

\subsection{METHODOLOGY}

\subsubsection{Theoretical model}

The theoretical framework for the analysis of nonfarm activities involves different streams of literature and cuts across several disciplines (Ellis, 1998). At the micro level, the starting point is the theory of agricultural household models, where the household has a dual role of producer and consumer. If markets are perfect, the household first maximises profit by choosing different sets of income activities based on its resources and prices, and then maximises utility by choosing between different levels of consumption and leisure given profits. However, in case of market imperfections production and consumption decisions become nonseparable (Taylor \& Adelman, 2003). This implies that households maximise utility, given their resources, the available technology, and (often householdspecific) market-access and prices (De Janvry \& Sadoulet, 1996). The first order conditions of farm household models provide a system of supply and demand functions that permits formulating labour allocation decision between different agricultural and non-agricultural activities.

Labour participation of household members in nonfarm activities is a function of incentives and constraints (Barret \& Reardon, 2000; Reardon et al. 2006). Incentives include the level and variability of prices and wages in both farm and nonfarm activities. These prices may differ substantially among households due to the heterogeneous access to markets, human capital, and assets endowments. Constraints are related to the capacity of household members to diversify into nonfarm activities. They include household, individual and locational characteristics, such as household assets, gender structure, access to infrastructure, education, age, and gender of household members and so forth.

The combination of constraints and incentives leads to paradoxes at the meso and micro level, as described by Reardon et al. (2006). At the meso level, household members have higher incentives to engage in nonfarming in poor resource areas, but their capacity to generate these activities is limited in these regions. At the micro level, the same picture evolves, when poor household members have higher incentives to diversify into nonfarm activities but a lower capacity to do this successfully due to the lack of assets. In this case, the poor are 
often engaged in nonfarm activities with low-return equivalent to subsistence farming.

Following the incentives and capacity approach, we hypothesise that the same characteristic of a region, household or individual may have a dual impact on the participation in nonfarm activities through its potentially conflicting effect on incentives and capacity. For example, larger land endowments may diminish the incentives to engage in the RNFE but can increase the capacity to undertake or expand nonfarm activities with high returns by either investing cash from agricultural activities or using land as collateral to get financial resources. Similarly, cattle ownership may decrease the need to engage in the RNFE but its proceeds may facilitate engagement in profitable nonfarm activities. Human capital may also have a diverse impact on participation and income from the RNFE. For example, some nonfarm activities may traditionally be mostly occupied by women, while returns are biased towards men.

\subsubsection{Data description and proposed estimation techniques and specifications}

The data used for the analysis comes from two representative household budget surveys conducted by the National Statistical Committee of the Kyrgyz Republic in 2005 and 2006. Due to the lack of income data in the survey conducted in 2003, it was not considered in this paper. We use only data for rural households, comprising about 1800 observations for each year. Information on individual employment is available at the quarterly basis and includes time spent, sector of occupation, and type of employment. In this work only locally employed people are considered, and migrants are excluded from the analysis.

We consider all economic activities in rural areas except primary agriculture, livestock, fishing and hunting part of the RNFE. We distinguish two types of nonfarm activities. Following World Bank (2007), we classify nonfarm employment financed mainly through state or local government budgets as public employment. This includes education, public administration, health and social services. The remainder of nonfarm employment is commercial employment and includes both private sector employment and provision of public services on a commercial basis. We used this distinction because commercial nonfarm activities are likely to have different determinants than those financed through public budgets and we are particularly interested what stimulates commercial initiatives. Nonfarm income includes self-employment and wage income from all (primary and additional) nonfarm jobs of the different household members. We include only earned income, as we are interested in nonfarm employment and the incomes associated with this.

Total income is the sum of nonfarm income, farm income, and unearned income from scholarships, interest incomes, social benefits, and net transfers. We 
calculated farm income as the sum of aggregate farm wages for all household members and income from the peasant farm or subsidiary plot, which includes net income from crops and animals. Net crop income is obtained by subtracting gross costs from the volume harvested times median sales prices at the regional level. Livestock income consists of net income from sold live animals and raw animal products, such as meat, eggs, milk, skin and so forth. Net income is obtained by subtracting gross production expenditure from the quantity of sold animals times producer median prices and the quantity of produced raw animal products times consumer median prices in the relevant region.

The empirical models are specified as follows:

$Y_{i}=\Phi(I, H, A, ~ I n f, ~ L c t), i=1,2,3$,

where $Y$ is the dependent variable reflecting individual participation in nonfarm activities or nonfarm income depending on the empirical model. In the first model, $\mathrm{Y}$ is participation in three distinct sets of activities, using data for both primary and secondary employment: farm activities only, nonfarm activities only, and a combination of farm and nonfarm activities. In the second model, $\mathrm{Y}$ reflects participation in specific nonfarm activities based on functional and sectoral criteria: wage employment in private organisations, wage employment in the public sector, self-employment, and employment by individuals. For the third model Y reflects the logarithm of income from self-employment, public wage employment, and private wage employment. The explanatory variables are derived from the theoretical considerations described above and are grouped into individual characteristics $(I)$, household characteristics $(H)$, household assets (A), location characteristics $(L c t)$, and access to infrastructure (Inf).

Individual characteristics include age, gender, marital status, education level (higher, vocational, secondary and less than secondary). Education is an important part of human capital, which determines both participation in and income from nonfarm activities (Yunez-Naude \& Taylor, 2001; Reardon et al., 2006). In Latin American countries, for instance, people with better education avoid farm wage employment and are mostly engaged in wage employment in nonfarming (Reardon et al., 2001).

Household characteristics mostly involve the demographic structure of the household, namely the size of the household, the dependence ratio measured as a ratio of children (under 15) and old people (over 65) to total household size, and age, gender and educational level of the head of the household. Many studies found a positive relationship between the labour endowment (measured as the number of adults) of the household and its participation in the RNFE (Davis et al., 2007). 
The asset group of explanatory variables includes the number of cattle at the beginning of the considered year and the size of owned land. ${ }^{26}$ Both variables can affect participation and income from nonfarm activities. In Africa, many studies found that land had a positive impact on the probability of being employed in nonfarm activities and that larger landowners received higher share of income from nonfarm activities (see, for example, Abdulai \& CroleRees, 2001). In contrast, in Latin America, the share of nonfarm income was found to fall with land size, meaning that poor households were pushed into nonfarming due to land scarcity and excess of labour (see Reardon et al., 2001). The size of the livestock was also found to be an important determinant of participation in high-return nonfarm activities versus low-return ones (see, for example, Lay et al., 2007).

One important problem with using amount of land and the number of cattle is that both variables can be endogenous. Unfortunately, using cross-section data limits our ability to solve this issue. Still we hope that the size of owned land is less prone to be endogenous relative to total land because of the underdevelopment of land markets in Kyrgyzstan and limitations on purchases of land. We also re-estimated multinomial logit and self-employment income regression from the double-hurdle models for 2005 year excluding both the size of land and the number of cattle to check whether this affects other coefficients. Afterwards, we exclude land and check the impact on coefficient for the number of cattle and vice versa. As shown in the annex, no serious changes in the magnitude and the sign of coefficients occurred.

Location characteristics and access to infrastructure are measured at the rayon level. The normative values of land tax on arable land are included as a measure of land quality: a higher tax means better quality of land. The size of the rural population in the rayon and the distance from the rayon centre to the regional centre serve as a proxies for market size and access. We include a dummy for a famous resort area to test the hypothesis about importance of the local "engines" of growth besides agriculture. Dummy variables for regions and quarters are used to control for regional fixed effects and seasonality. Access to public assets is measured by percentage of the population having access to clean water through infrastructure (pipe, pump and so forth), and average time needed to get to the closest bus-stop at the district level.

Several empirical studies demonstrate the importance of location characteristics and access to infrastructure for participation in the RNFE. Isgut (2004), for example, found that wage employment in the RNFE was located closer to urban areas, while self-employment mostly depended on local motors, such as profitable agricultural activity, tourist attraction and so forth. Reardon et al. (2001) demonstrated that access to infrastructure was crucial for participation and income

26 The size of owned land does not include leased land to diminish the risk of endogeneity discussed below. 
from nonfarm activities compensating for lack of other assets in Latin American countries. Jonasson and Helfand (2010) also showed that local market size, distance to population centres, and other proxies for transactions costs played an important role in shaping nonfarm employment in Brazil.

The choice of dependent variables is based on specific research questions to be answered and will require various estimation techniques that account for their specific distribution. The first question is which factors determine the choice of an individual between doing farm, nonfarm or combination of both activities. Since we have more than two outcomes, we used multinomial logit regression to estimate the first model. As we are particularly interested which variables explain the choice between pure farm and nonfarm activities, pure farm category is chosen as a reference category.

One important limitation of multinomial logit is the assumption of independence from irrelevant alternatives (IIA). It implies that adding another alternative or changing the characteristics of a third alternative does not affect the relative odds between alternatives. Applying to our data, it implies that if the option of working only in agriculture disappears, people who were previously employed only in farming would switch to pure nonfarm activities or their mixture with agriculture in the same proportion as other rural individuals. Hausman and McFadden and Small-Hsiao tests can be used to test independence of irrelevant alternatives assumption (Hausman \& McFadden, 1984; Small \& Hsiao, 1985).

The second question is which variables determine participation in particular nonfarm activities. We hypothesise that different nonfarm activities may have different determinants of participation. As we are not interested in obtaining results in comparison to one particular group, such as participation in pure farming in the first model, we use probit regression to estimate our equations for participation in four particular groups of nonfarm activities. Both multinomial logit and probit were frequently used for the analysis of participation in the RNFE (Corral \& Reardon, 2001; Escobal, 2001; Woldenhanna \& Oskam, 2001). As unobserved factors could have an impact on four choices, error terms can be correlated. In this case, using multivariate probit would be a better choice (Cappellari \& Jenkins, 2003). We will present results from both regressions.

Finally, we analyse the income from nonfarm activities. As our data do not allow us separating income into the four categories used for the probit regressions, we distinguish between self-employment, public wage employment and private wage employment instead. For the third model, yet another econometric technique is needed as our dependent variable, nonfarm earnings, is continuous but censored at zero. As OLS will give biased results, Tobit regression is usually used for such data. This method has, however, two important limitations. First, it assumes that explanatory variables have the same impact on the probability of being employed in nonfarm activities and on the size of nonfarm income. This does not allow for situations in which some variables may diminish incentives to start nonfarming 
but in case of participation increase nonfarm income by means of the strengthened capacity or better access to higher remunerative activities. Second, the Tobit model considers zero values as corner solution, but an individual may prefer not to engage into nonfarming for social reasons irrespective of the value of exogenous variables. On the contrary, the widely used Heckman selection model allows for such reasons for non-participation but rules out corner solutions, when zeros in nonfarm income are driven by economic reasons (Matshe \& Young, 2004).

An alternative to Tobit and Heckman models is the two-step doublehurdle model initially developed by Cragg (1971) to model the demand for durable goods. Its different versions were also used to model gambling behaviour (Humphreys, Lee \& Soebbing, 2009), loan default (Moffatt, 2005), market contract decisions (Katchova \& Mirande, 2004).

The double-hurdle model has a participation equation:

$$
\begin{aligned}
& D_{i}=1 \text { if } D_{i}^{*}>0 \text { and } 0 \text { if } D_{i}^{*} \leq 0 \\
& D_{i}^{*}=\alpha^{\prime} Z_{i}+u_{i}
\end{aligned}
$$

Where $\mathrm{D}^{*}$ is a latent participation variable that takes the value of 1 if the respondent undertook nonfarm employment and 0 otherwise, $\mathrm{Z}$ is a vector of individual, household and local characteristics and $\alpha$ is a vector of parameters.

The level $(Y)$ equation:

$$
\begin{aligned}
& Y_{i}=Y_{i}^{*} \text { if } Y_{i}^{*}>0 \text { and } D_{i}^{*}>0 \\
& Y_{i}=0 \text { otherwise } \\
& Y_{i}^{*}=\beta^{\prime} X_{i}+v_{i}
\end{aligned}
$$

Where $\mathrm{Y}$ is an observed level of monthly nonfarm income, $\mathrm{X}$ is a vector of individual, household and local characteristics and $\beta$ a vector of parameters.

The errors terms are distributed as follows:

$u_{i} N(0,1)$

$v_{i} N\left(0, \sigma^{2}\right)$

Following Cragg, we consider a hurdle model where rural inhabitant makes a two-step decision. In the first step, the probit model represents an individual's choice of whether to participate in the RNFE or not. If the first "hurdle" is crossed, a truncated regression describes how much he or she can earn from nonfarm activity. The log-likelihood for the double-hurdle model is:

$$
\log L=\sum_{o} \ln \left[1-\Phi\left(\alpha Z_{i}^{\prime}\right)\left(\frac{\beta X_{i}^{\prime}}{\sigma}\right)\right]+\sum_{+} \ln \left[\Phi\left(\alpha Z_{i}^{\prime}\right) \frac{1}{\sigma} \phi\left(\frac{Y_{i}-\beta X_{i}^{\prime}}{\sigma}\right)\right]
$$

In which " 0 " indicates summation over the zero observations, while " + " indicates summation over positive observations. $\Phi($.$) and \phi($.$) are the standard$ normal probability and density functions respectively (Moffatt, 2005). 
Under the assumption of independency between the error terms, the model is equivalent to a combination of a truncated regression model and a probit model. The Tobit model can be tested against double hurdle model by computing the following likelihood ratio statistic $\lambda=2(\ln$ Lbinary $+\ln$ Ltruncated $-\ln$ LTobit), where $\lambda$ is distributed as chi-square with $R$ degrees of freedom ( $R$ is the number of independent variables including a constant). The Tobit model will be rejected in favour of double hurdle model if $\lambda$ exceeds the appropriate chi-square critical value (Green, 2000).

Importantly that the results obtained from the double-hurdle model should be treated cautiously because they rely on the assumptions of homoscedasticity and normality of errors which can be violated. According to Wilhelm (2008), using censored least absolute deviation estimator (CLAD) developed by Powell (1984) is preferred in the presence of heteroscedasticity and censored dependent variables. However, this estimator will not allow us testing whether the same determinants have different impact on participation and income from nonfarm activities. ${ }^{27}$

To the best of our knowledge, in the nonfarm literature only Matshe and Young (2004) used double hurdle models to explain off-farm labour allocation decisions. They found that gender, education and assets had different impacts on participation in nonfarm activities and hours worked of small households in Shamva district in Zimbabwe.

\subsection{THE ROLE OF THE RNFE}

While most people in rural areas of the Kyrgyz Republic were still employed in agriculture in 2005 and 2006, the RNFE provided substantial employment. ${ }^{28}$ The nonfarm sector provided $37.8 \%$ and $39.6 \%$ of all primary jobs, but only a very small share of secondary and tertiary jobs. The shares of nonfarm time in total time worked also demonstrate the importance of the RNFE, and for primary employment they are even higher than shares of nonfarm employment. This is related to farm underemployment reflected in higher primary workload in the RNFE in comparison to highly seasonal and much smaller workload in agriculture.

\footnotetext{
${ }^{27}$ We have also tried to estimate nonfarm income equations using CLAD, however convergence has not been achieved.

${ }^{28}$ This section has some overlap with section 3.3.2 from Chapter 3, but it also presents new information on the distribution of nonfarm income per capita and nonfarm income shares across income quintiles.
} 
Table 4.1. Share of nonfarm employment to total rural employment and share of time worked in nonfarm activities to total hours worked in rural areas, $\%$

\begin{tabular}{|c|c|c|}
\hline & 2005 & 2006 \\
\hline \multicolumn{3}{|c|}{ By type of employment } \\
\hline Main employment & $37.8 \%$ & $39.6 \%$ \\
\hline Secondary employment & $2.7 \%$ & $2.2 \%$ \\
\hline Tertiary employment & $0.2 \%$ & $0.1 \%$ \\
\hline \multicolumn{3}{|c|}{$\begin{array}{l}\text { By hours worked in nonfarm activities to total } \\
\text { hours worked }\end{array}$} \\
\hline Main employment & $44.3 \%$ & $48.2 \%$ \\
\hline Secondary employment & $2.2 \%$ & $2.0 \%$ \\
\hline Tertiary employment & $0.1 \%$ & $0.0 \%$ \\
\hline Total nonfarm employment & $46.4 \%$ & $50.0 \%$ \\
\hline
\end{tabular}

Source: NSC, authors' calculation

Note: indicators are obtained by summing individual data on employment status and time worked during the week at the regional and country levels.

The structural distribution of primary nonfarm employment shows that in 2005 and $200661 \%$ and $65 \%$ were generated in commercial sectors accordingly. The most important commercial sectors in 2005 were trade $(19 \%)$, processing $(11 \%)$, transport and communications (10\%). Education played the leading role among public nonfarm sectors accounting for $20 \%$ in total nonfarm employment.

Mean shares of nonfarm income in total rural income followed the employment pattern and increased from $31 \%$ in 2005 to $39 \%$ in 2006 . The functional distribution of nonfarm income shows that income from wage employment represented the largest share in total nonfarm income followed by nonfarm self-employment income.

Table 4.2. Mean nonfarm income shares, nonfarm and farm income per capita across quintiles based on total income per capita, som

\begin{tabular}{|c|c|c|c|c|c|c|}
\hline & \multicolumn{3}{|c|}{2005} & \multicolumn{3}{|c|}{2006} \\
\hline Quintiles & $\begin{array}{l}\text { Nonfarm } \\
\text { income } \\
\text { share, } \%\end{array}$ & $\begin{array}{c}\text { Nonfarm } \\
\text { income per } \\
\text { capita, som }\end{array}$ & $\begin{array}{c}\text { Farm } \\
\text { income per } \\
\text { capita, som }\end{array}$ & $\begin{array}{c}\text { Nonfarm } \\
\text { income } \\
\text { share, \% }\end{array}$ & $\begin{array}{l}\text { Nonfarm } \\
\text { income per } \\
\text { capita, som }\end{array}$ & $\begin{array}{c}\text { Farm } \\
\text { income per } \\
\text { capita, som }\end{array}$ \\
\hline 1 & $44 \%$ & $\begin{array}{c}2367 \\
(68.7 \%)\end{array}$ & $\begin{array}{c}1552 \\
(83.3 \%)\end{array}$ & $45 \%$ & $\begin{array}{c}2627 \\
(60.8 \%)\end{array}$ & $\begin{array}{c}1575 \\
(83.4)\end{array}$ \\
\hline 2 & $36 \%$ & $\begin{array}{c}2955 \\
(76.6 \%)\end{array}$ & $\begin{array}{c}3184 \\
(96.3 \%)\end{array}$ & $52 \%$ & $\begin{array}{c}4427 \\
(84.4 \%)\end{array}$ & $\begin{array}{c}2806 \\
(90.7)\end{array}$ \\
\hline 3 & $29 \%$ & $\begin{array}{c}4209 \\
(65.2 \%)\end{array}$ & $\begin{array}{c}5943 \\
(90 \%)\end{array}$ & $38 \%$ & $\begin{array}{c}5163 \\
(74.6 \%)\end{array}$ & $\begin{array}{l}5800 \\
(92.6)\end{array}$ \\
\hline 4 & $25 \%$ & $\begin{array}{c}4652 \\
(70 \%)\end{array}$ & $\begin{array}{c}8851 \\
(97.4 \%)\end{array}$ & $35 \%$ & $\begin{array}{c}7309 \\
(76.7 \%)\end{array}$ & $\begin{array}{l}9096 \\
(97.5)\end{array}$ \\
\hline 5 & $19 \%$ & $\begin{array}{c}9069 \\
(58.8 \%)\end{array}$ & $\begin{array}{c}28724 \\
(99.8 \%)\end{array}$ & $24 \%$ & $\begin{array}{l}11614 \\
(63.7)\end{array}$ & $\begin{array}{c}24081 \\
(94.8 \%)\end{array}$ \\
\hline
\end{tabular}


Source: NSC, authors' calculation

Notes: average incomes for households having a certain income source are given. $\%$ of households with this source of income in each quintile is provided in brackets.

The distribution of nonfarm earnings across income quintiles demonstrates the importance of nonfarm income for poor rural households. For both years the share of nonfarm income was decreasing with larger total income per capita. For example, in 2006 the poorest rural households obtained $45 \%$ of their total income from nonfarming versus $24 \%$ of the richest households. Differences between quintiles were also pronounced for farm and nonfarm income per capita. Thus, in 2005 farm income per capita for the fifth quintile was three times larger than income from nonfarming.

\subsection{EMPIRICAL RESULTS}

Table 4.3 presents the determinants of individual participation in nonfarm activities based on multinomial logit regressions for 2005. We also report results for 2006 in table A.4.2 of the Annex to this chapter and find the results are robust across the considered years. ${ }^{29}$ Two categories of nonfarm participation - pure nonfarm and a mixture of farm and nonfarm activities are compared to the base category of pure agricultural activities. The table reports risk ratios, which are the coefficients in exponential form and which indicate how the risk of the outcome falling in the comparison group compares to the risk of the outcome falling in the reference group changes with the variable in question. A ratio greater than (less than) one indicates a higher (lower) probability of choosing nonfarm activities or a mixture of nonfarm with farm over pure agricultural activities.

Both Hausman and Small-Hsiao tests of independence of irrelevant alternatives do not reject the null hypothesis indicating the appropriateness of the estimation method (Hausman \& McFadden, 1984; Small \& Hsiao, 1985). ${ }^{30}$ We also use Wald and log-likelihood tests to check whether outcomes can be combined, but the tests reject this.

Table 4.3. Relative risk ratios for participation in nonfarm activities in 2005 based on multinomial logit

Farm and
Only nonfarm
nonfarm (mixed)

Individual characteristics

Age $1.245^{* * *} \quad 1.245^{* * *}$

[0.0402] [0.0402]

${ }^{29}$ We replicated the analysis on the pooled sample, but results stay the same.

${ }^{30}$ Results of IIA tests for both years are provided in the annex. 


\begin{tabular}{|c|c|c|}
\hline & Only nonfarm & $\begin{array}{c}\text { Farm and } \\
\text { nonfarm (mixed) }\end{array}$ \\
\hline \multirow[t]{2}{*}{ Age squared } & $0.997^{* * *}$ & $0.997^{* * *}$ \\
\hline & {$[0.000423]$} & [0.000409] \\
\hline \multirow[t]{2}{*}{ Dummy, 1 for male } & 1.223 & 1.043 \\
\hline & {$[0.150]$} & {$[0.134]$} \\
\hline \multirow[t]{2}{*}{ Dummy, 1 for married } & $0.507^{* * *}$ & 1.159 \\
\hline & {$[0.0783]$} & {$[0.178]$} \\
\hline \multirow[t]{2}{*}{ Dummy, head } & 0.991 & 1.236 \\
\hline & {$[0.151]$} & [0.192] \\
\hline \multirow[t]{2}{*}{ Dummy, Kyrgyz } & $0.560^{* * *}$ & $0.560^{* * *}$ \\
\hline & {$[0.0922]$} & [0.0897] \\
\hline \multirow{2}{*}{$\begin{array}{l}\text { Dummy, higher education (university } \\
\text { degree) }\end{array}$} & $21.53^{* * *}$ & $14.59^{* * *}$ \\
\hline & [5.923] & {$[4.558]$} \\
\hline \multirow[t]{2}{*}{ Dummy, vocational education } & $3.867^{* * *}$ & $3.088^{* * *}$ \\
\hline & {$[0.805]$} & {$[0.823]$} \\
\hline \multirow[t]{2}{*}{ Dummy, secondary education } & $1.421^{*}$ & 1.144 \\
\hline & {$[0.282]$} & {$[0.304]$} \\
\hline \multicolumn{3}{|l|}{ Household characteristics } \\
\hline \multirow[t]{2}{*}{ Size of the household } & 1.057 & 0.984 \\
\hline & {$[0.0428]$} & {$[0.0345]$} \\
\hline \multirow[t]{2}{*}{ Dependence ration } & $0.299^{* * *}$ & $0.544^{* *}$ \\
\hline & {$[0.0965]$} & [0.149] \\
\hline \multirow[t]{2}{*}{ Age of the head of household } & 0.992 & $0.990^{*}$ \\
\hline & {$[0.00566]$} & {$[0.00591]$} \\
\hline \multirow{2}{*}{$\begin{array}{l}\text { Gender of the head of household, } 1 \text { for } \\
\text { male }\end{array}$} & 0.862 & 0.797 \\
\hline & {$[0.151]$} & {$[0.133]$} \\
\hline \multirow{2}{*}{$\begin{array}{l}\text { Dummy, head of household has higher } \\
\text { education (university degree) }\end{array}$} & 1.144 & 1.407 \\
\hline & {$[0.308]$} & [0.319] \\
\hline \multicolumn{3}{|l|}{ Assets } \\
\hline \multirow{2}{*}{$\begin{array}{l}\text { Number of cattle at the beginning of the } \\
\text { year }\end{array}$} & $0.982^{* * *}$ & $0.996^{*}$ \\
\hline & {$[0.00518]$} & {$[0.00245]$} \\
\hline \multirow[t]{2}{*}{ Owned land, ha } & $0.771^{* * *}$ & $0.763^{* * *}$ \\
\hline & {$[0.0404]$} & {$[0.0367]$} \\
\hline \multirow[t]{2}{*}{ Owned land squared } & $1.005^{* * *}$ & $1.005^{* * *}$ \\
\hline & [0.00108] & {$[0.000965]$} \\
\hline \multicolumn{3}{|l|}{ Access to public utilities } \\
\hline \multirow[t]{2}{*}{$\%$ of having access to water } & $1.013^{* * *}$ & $1.013^{* * *}$ \\
\hline & [0.00344] & [0.00308] \\
\hline \multirow[t]{2}{*}{ Time needed to get to the bus stop } & 1.011 & $1.075^{* * *}$ \\
\hline & {$[0.0219]$} & {$[0.0210]$} \\
\hline \multicolumn{3}{|l|}{ Locational characteristics } \\
\hline \multirow{2}{*}{$\begin{array}{l}\text { Basic land tax at rayon level, higher tax } \\
\text { means better quality of land }\end{array}$} & $0.997^{* * *}$ & 1 \\
\hline & [0.000792] & [0.000756] \\
\hline \multirow[t]{3}{*}{ Size of rural population in rayon } & $1.005^{* * *}$ & 1.002 \\
\hline & {$[0.00159]$} & {$[0.00157]$} \\
\hline & 60 & \\
\hline
\end{tabular}




\begin{tabular}{lcc}
\hline & Only nonfarm & $\begin{array}{c}\text { Farm and } \\
\text { nonfarm (mixed) }\end{array}$ \\
\hline Distance from rayon centres to regional & 1.003 & $1.009^{* * *}$ \\
centres & {$[0.00208]$} & {$[0.00201]$} \\
Dummy for resort area in Issykkul region & 1.636 & $3.788^{* * *}$ \\
& {$[0.656]$} & {$[1.372]$} \\
\hline Observations & 12069 \\
Pseudo R & 0.2173 \\
Wald chi2 & 958.63 \\
Probability>chi2 & \multicolumn{2}{c}{0.00} \\
\hline
\end{tabular}

Source: NSC, authors' estimation.

Notes: The base category is pure farming. ${ }^{* *} \mathrm{p}<0.01,{ }^{* *} \mathrm{p}<0.05,{ }^{*} \mathrm{p}<0.1$. Intercepts, dummy for 2005, regional and quarterly dummies are not reported. Weighted, robust, and clustered at the household level standard errors are in parentheses.

We find empirical evidence that participation in nonfarm activities is driven mostly by "push" factors, but there is also an indication of "pull" factors at work. A "push" scenario happens when participation in nonfarm activities is driven by inability to earn enough from agricultural activities due to a poor asset base or risky agricultural environment. Imperfections in rural institutions, such as access to credit or insurance markets can also stimulate nonfarm activities. A "pull" scenario means that participation in nonfarm activities is driven by higher payoffs or lower risk in the nonfarm sector compared to agriculture. The combined relevance of "push" and "pull" factors suggests that there are two sets of nonfarm activities: those who serve as last resort activities for the poor, and those that provide profitable opportunities for those who have access to them. Most of the obtained results are robust across the two years and the two outcomes for pure nonfarm and a mixture of nonfarm with farm activities. Let us consider which factors contributed to particular scenarios.

Quite a few variables provide evidence of "push" incentives behind participation in the RNFE. Small land size and poor land quality make individuals choose employment in the nonfarm sector over agricultural activities. The negative influence of the number of cattle ${ }^{31}$ and the age of household head is also in line with the "push" scenario and indicates that access to liquid assets or a stable source of cash through a pension system diminishes incentives to choose nonfarm activities over farming. Finally, the positive effect of the distance from rayon centres to regional centres on the choice of nonfarm activities over pure agriculture suggests that households start nonfarming in remote areas to compensate for low agricultural margins.

31 This is different from empirical findings in some African countries where possession of cattle may help to overcome entrance barriers to start nonfarm activities with high returns (see, for example, Abdulai \& CrolRees, 2001). 
There is also some evidence in favour of the "pull" scenario of participation in nonfarm activities. For instance, a marginal increase in the size of land decreases the probability of choosing nonfarm employment at a decreasing rate, indicating that there may be less incentives for individuals with ample land to divert from nonfarming since they may be able to engage in more profitable activities due to access to cash resources from agriculture or because they can develop nonfarm activities dependent on agriculture. Yet, a large majority of individuals are on decreasing part of the curve where more land means less participation in the nonfarm economy. The last "pull" factor is related to the impact of other sources of growth. In our case, the availability of resort area is found to pull individuals from farm activities into the RNFE.

Besides "push" and "pull" factors, participation in nonfarm activities is influenced by different human capital and infrastructure variables which affect the capacity of rural inhabitants to choose other than pure farm activities. Thus, better educated individuals, especially with higher or vocational education, are more likely to choose pure nonfarm activities or a mixture of farming and nonfarming, mostly because they are better qualified for formal nonfarm jobs. Having more dependents constrains participation in the RNFE due to the trade-off in allocation of labour between farm and nonfarm activities.

To get more insight in the determinants of specific nonfarm activities we analysed participation in self-employment, private organisations, public organisations and employment by individuals. Marginal effects of the probit regressions are presented in table 4.4. Results from the multivariate probit for 2005 year are presented in the annex. Coefficients on the explanatory variables have the same sign as in the probit models. Therefore we continue discussing several interesting findings based on marginal effects from the probit regressions below.

Different nonfarm activities require different types of capital. For example, there are significant differences in effects of gender and education on employment in organisations, self-employment and employment by individuals. Women are more likely to be engaged in public RNFE, while men are more likely to be employed by private organisations or individuals. Employment in public and private organisations requires higher education in contrast to participation in selfemployment/employment by individuals which requires only secondary or vocational education. Access to public services, proxied by the access to clean water, stimulates participation in private nonfarm employment, indicating that such services facilitate a profitable private sector.

With regards to "push" and "pull" scenarios behind specific nonfarm activities, we again found a combination of mostly "push" and some "pull" factors, consistent with the results from multinomial logit. Little land, its poor quality and lack of access to cash resources push individuals into all types of nonfarm employment. Interestingly, low, but secure payment in public organisations works 
as a "harbour" attracting individuals in areas with lower economic potential due to remoteness and lack of other sources of growth.

Having identified the determinants of participation in nonfarm activities, we can proceed with the analysis of nonfarm income determinants (selfemployment, private and public salary) to test our hypothesis that some explanatory variables may have different effects on the probability of participation in nonfarm activities and on income from them. Results from a double hurdle model are presented in table 4.5. As the first stage represents participation, which has been discussed extensively above, we now focus on the second stage, which describes the determinants of the level of income given that a person participates in a certain activity. Since results for 2006 are very similar to results for 2005 we present the 2006 results in the annex.

We conclude that human capital, access to infrastructure and cash resources not only influence access to nonfarm activities, but also determine the level of income from these activities. Thus, being older increases the level of salary in public and private nonfarm employment, but age does not have an impact on self-employment income given participation. This may be related to the fact that self-employment income is based on low-returns activities, the income from which does not depend much on experience.

Gender and education were also identified as crucial determinants of nonfarm income. Males, for instance, receive higher nonfarm income both from self-employment and wage employment. Even in case of public nonfarm sectors, where females have much higher probability of working than males, males receive higher salaries than females. Education, and especially higher education, is also found to be a strong positive determinant of nonfarm income and wages. Interestingly, while higher education has no effect on participation in selfemployment activities, it significantly increases self-employment income.

Some locational characteristics and access to cash resources help rural individuals to get higher nonfarm income and salaries even though they affect participation in the RNFE negatively. Access to infrastructure and markets, measured as time needed to get to the closest bus stop and as the distance from rayon centres to regional cities, significantly increases income from selfemployment and salary level from private wage employment. This means that residence in remote areas pushes households into nonfarm activities, but given participation, inadequate access to infrastructure seriously limits nonfarm income.

Table 4.4. Marginal effects of the probit model for primary participation in rural nonfarm activities in 2005 at the mean of explanatory variables

\begin{tabular}{cccc}
$\begin{array}{c}\text { Self- } \\
\text { employment }\end{array}$ & $\begin{array}{c}\text { Employment } \\
\text { by individuals }\end{array}$ & $\begin{array}{c}\text { Employment } \\
\text { in commercial } \\
\text { organisations }\end{array}$ & $\begin{array}{c}\text { Employment } \\
\text { in public } \\
\text { organisation }\end{array}$ \\
\hline
\end{tabular}

Individual characteristics

Age

$0.0135^{* * *}$

$0.00316^{* *}$

$0.00503^{* * *}$

$0.00895^{* * *}$ 


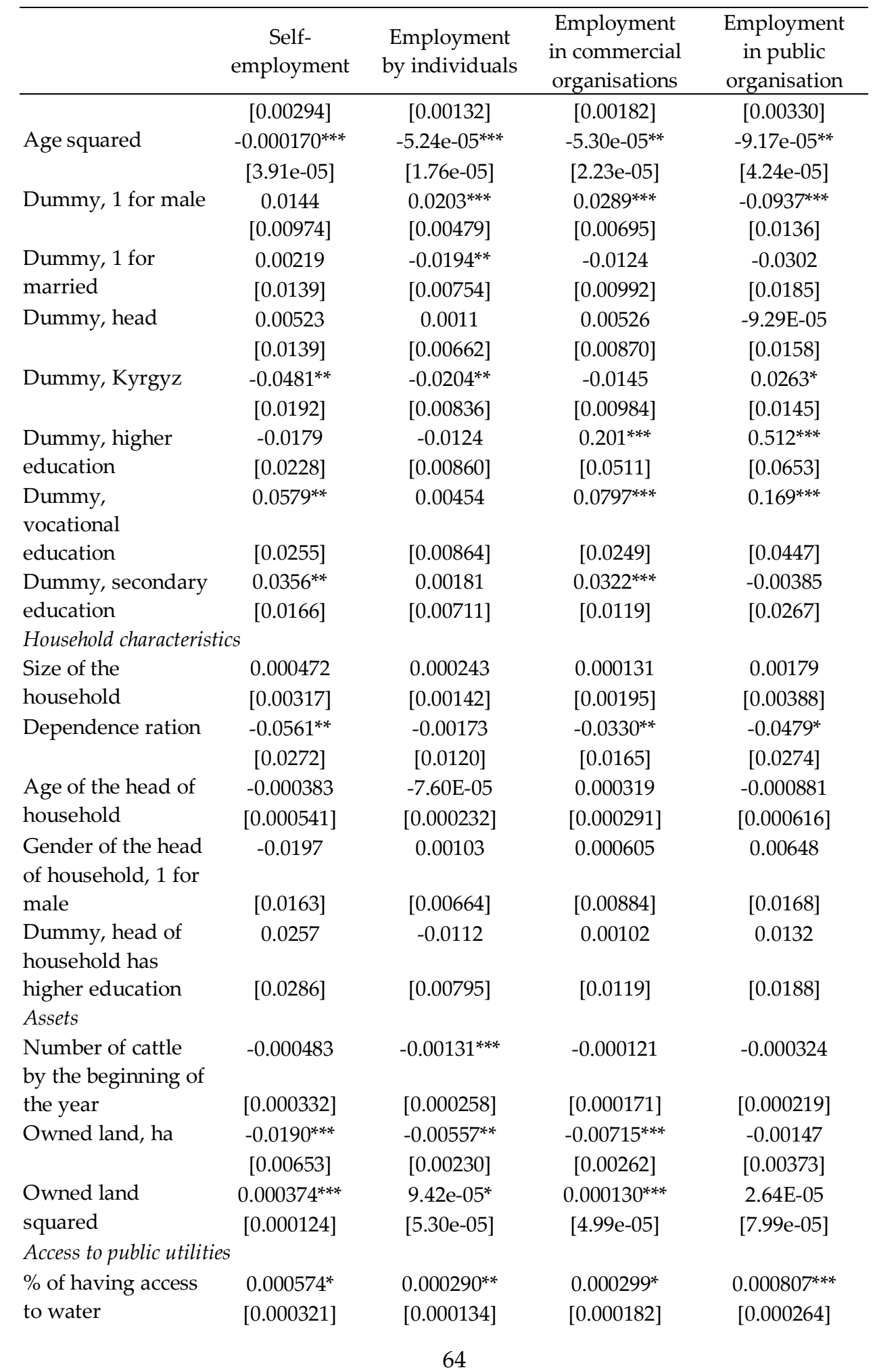




\begin{tabular}{|c|c|c|c|c|}
\hline & $\begin{array}{c}\text { Self- } \\
\text { employment }\end{array}$ & $\begin{array}{c}\text { Employment } \\
\text { by individuals }\end{array}$ & $\begin{array}{c}\text { Employment } \\
\text { in commercial } \\
\text { organisations } \\
\end{array}$ & $\begin{array}{l}\text { Employment } \\
\text { in public } \\
\text { organisation }\end{array}$ \\
\hline $\begin{array}{l}\text { Time needed to get } \\
\text { to the bus stop }\end{array}$ & $\begin{array}{l}0.000611 \\
{[0.00167]}\end{array}$ & $\begin{array}{c}-0.00123 \\
{[0.000906]}\end{array}$ & $\begin{array}{c}-0.00211 \\
{[0.00136]}\end{array}$ & $\begin{array}{l}0.00624^{* * *} \\
{[0.00172]}\end{array}$ \\
\hline \multicolumn{5}{|c|}{ Locational characteristics } \\
\hline $\begin{array}{l}\text { Basic land tax at } \\
\text { rayon level, higher } \\
\text { tax better quality of } \\
\text { land }\end{array}$ & $-0.000158^{* *}$ & $-3.20 \mathrm{E}-06$ & $-4.19 \mathrm{E}-05$ & -0.000107 \\
\hline $\begin{array}{l}\text { Size of rural } \\
\text { population in }\end{array}$ & $0.000302^{* *}$ & $0.000119^{*}$ & $-5.83 \mathrm{E}-05$ & $-3.34 \mathrm{E}-05$ \\
\hline rayon & {$[0.000130]$} & [6.18e-05] & [9.06e-05] & {$[0.000153]$} \\
\hline $\begin{array}{l}\text { Distance from } \\
\text { rayon centres to }\end{array}$ & 0.000302 & $0.000188^{* *}$ & $-5.99 \mathrm{E}-05$ & $0.000391^{* *}$ \\
\hline regional centres & [0.000196] & [7.98e-05] & [0.000107] & [0.000167] \\
\hline $\begin{array}{l}\text { Dummy for resort } \\
\text { area in Issykkul }\end{array}$ & 0.112 & 0.0042 & $0.255^{* * *}$ & $-0.0742^{* * *}$ \\
\hline region & [0.0851] & [0.0138] & {$[0.0754]$} & [0.0103] \\
\hline Observations & 12069 & 12069 & 12069 & 12069 \\
\hline Pseudo R2 & 0.143 & 0.197 & 0.209 & 0.286 \\
\hline Wald chi2(33) & 243.99 & 277.03 & 361.42 & 546.46 \\
\hline obs. P & 0.098 & 0.058 & 0.069 & 0.141 \\
\hline pred. P & 0.067 & 0.024 & 0.0347 & 0.083 \\
\hline
\end{tabular}

Source: NSC, authors' estimation

Note: ${ }^{* *} \mathrm{p}<0.01,{ }^{* *} \mathrm{p}<0.05,{ }^{*} \mathrm{p}<0.1$ Regional and quarterly dummies are not reported.

Weighted, robust, and clustered at the household level standard errors are in parentheses.

The availability of non-agricultural sources of growth, proxied by a famous resort area in our model, substantially increases income from private nonfarm activities. Finally, in spite of its negative impact on participation in private nonfarm wage and self-employment, access to liquid assets in the form of cattle is found to have significant positive impact on the size of nonfarm income. Hence, being an alternative income source, cattle ownership discourages participation in the nonfarm sector, but for those who do participate, it is associated with higher income levels. For nonfarm self-employment this could mean that households use livestock income to invest in profitable activities. In the case of private nonfarm salaries, a possible explanation is that high wages are related to a post stream of similar wages that have partly been invested in livestock. 
Table 4.5. Double hurdle model, marginal effects after probit and results after truncated regression for logarithm of income from rural nonfarm activities, 2005 year

\begin{tabular}{|c|c|c|c|c|c|c|}
\hline & $\begin{array}{c}\text { Received } \\
\text { income from } \\
\text { nonfarm self- } \\
\text { employment }\end{array}$ & $\begin{array}{l}\text { Logarithm } \\
\text { of self- } \\
\text { employme } \\
\text { nt income }\end{array}$ & $\begin{array}{l}\text { Received } \\
\text { public } \\
\text { nonfarm } \\
\text { salary }\end{array}$ & $\begin{array}{l}\text { Logarithm of } \\
\text { public } \\
\text { nonfarm } \\
\text { salary }\end{array}$ & $\begin{array}{c}\text { Received } \\
\text { commercial } \\
\text { nonfarm } \\
\text { salary }\end{array}$ & $\begin{array}{c}\text { Logarithm of } \\
\text { commercial } \\
\text { nonfarm } \\
\text { salary }\end{array}$ \\
\hline \multicolumn{7}{|c|}{ Individual characteristics } \\
\hline Age & $\begin{array}{l}0.0138^{* * *} \\
{[0.00289]}\end{array}$ & $\begin{array}{l}-0.00429 \\
{[0.0244]}\end{array}$ & $\begin{array}{l}0.0102^{* * *} \\
{[0.00307]}\end{array}$ & $\begin{array}{c}0.0523^{* * *} \\
{[0.0147]}\end{array}$ & $\begin{array}{c}0.00825^{* * *} \\
{[0.00275]}\end{array}$ & $\begin{array}{l}0.0435^{* *} \\
{[0.0199]}\end{array}$ \\
\hline Age squared & $\begin{array}{c}-0.000172^{* * *} \\
{[3.84 \mathrm{e}-05]}\end{array}$ & $\begin{array}{c}4.65 \mathrm{E}-05 \\
{[0.000311]}\end{array}$ & $\begin{array}{c}-0.000107^{* * *} \\
{[3.95 \mathrm{e}-05]}\end{array}$ & $\begin{array}{c}-0.000563^{* * *} \\
{[0.000191]}\end{array}$ & $\begin{array}{c}-0.000103^{* * *} \\
{[3.50 \mathrm{e}-05]}\end{array}$ & $\begin{array}{c}-0.000646^{* *} \\
{[0.000258]}\end{array}$ \\
\hline $\begin{array}{l}\text { Dummy, } 1 \\
\text { for male }\end{array}$ & $\begin{array}{c}0.0167^{*} \\
{[0.00919]}\end{array}$ & $\begin{array}{l}0.172^{* *} \\
{[0.0757]}\end{array}$ & $\begin{array}{c}-0.0902^{* * *} \\
{[0.0126]}\end{array}$ & $\begin{array}{c}0.160^{* *} \\
{[0.0638]}\end{array}$ & $\begin{array}{l}0.0668^{* * *} \\
{[0.00999]}\end{array}$ & $\begin{array}{l}0.339^{* * *} \\
{[0.0823]}\end{array}$ \\
\hline $\begin{array}{l}\text { Dummy, } 1 \\
\text { for married }\end{array}$ & $\begin{array}{l}0.00167 \\
{[0.0130]}\end{array}$ & $\begin{array}{c}0.0975 \\
{[0.0975]}\end{array}$ & $\begin{array}{c}-0.0154 \\
{[0.0164]}\end{array}$ & $\begin{array}{c}-0.1 \\
{[0.0611]}\end{array}$ & $\begin{array}{c}-0.0385^{* * *} \\
{[0.0147]}\end{array}$ & $\begin{array}{c}0.112 \\
{[0.0979]}\end{array}$ \\
\hline $\begin{array}{l}\text { Dummy, } \\
\text { head }\end{array}$ & $\begin{array}{l}0.00376 \\
{[0.0129]}\end{array}$ & $\begin{array}{c}0.162^{*} \\
{[0.0911]}\end{array}$ & $\begin{array}{c}0.0114 \\
{[0.0149]}\end{array}$ & $\begin{array}{c}0.013 \\
{[0.0695]}\end{array}$ & $\begin{array}{l}0.00463 \\
{[0.0132]}\end{array}$ & $\begin{array}{l}-0.00371 \\
{[0.0930]}\end{array}$ \\
\hline $\begin{array}{l}\text { Dummy, } \\
\text { Kyrgyz }\end{array}$ & $\begin{array}{c}-0.0484^{* * *} \\
{[0.0187]}\end{array}$ & $\begin{array}{l}-0.178^{* *} \\
{[0.0887]}\end{array}$ & $\begin{array}{l}0.0254^{* *} \\
{[0.0126]}\end{array}$ & $\begin{array}{c}0.124^{*} \\
{[0.0668]}\end{array}$ & $\begin{array}{c}-0.0533^{* * *} \\
{[0.0166]}\end{array}$ & $\begin{array}{l}-0.0465 \\
{[0.0766]}\end{array}$ \\
\hline $\begin{array}{l}\text { Dummy, } \\
\text { higher }\end{array}$ & -0.016 & $0.594^{* * *}$ & $0.529^{* * *}$ & $1.249^{* * *}$ & $0.142^{* * *}$ & $0.329^{* *}$ \\
\hline education & [0.0215] & {$[0.191]$} & {$[0.0684]$} & {$[0.140]$} & [0.0427] & [0.167] \\
\hline $\begin{array}{l}\text { Dummy, } \\
\text { vocational }\end{array}$ & $0.0580^{* *}$ & $0.275^{*}$ & $0.184^{* * *}$ & $0.906^{* * *}$ & $0.0628^{* * *}$ & 0.129 \\
\hline education & {$[0.0253]$} & [0.152] & [0.0485] & {$[0.135]$} & [0.0237] & {$[0.136]$} \\
\hline $\begin{array}{l}\text { Dummy, } \\
\text { secondary }\end{array}$ & $0.0369^{* *}$ & 0.181 & 0.0187 & $0.717^{* * *}$ & 0.0253 & 0.182 \\
\hline education & [0.0162] & [0.146] & [0.0247] & {$[0.145]$} & {$[0.0166]$} & {$[0.129]$} \\
\hline \multicolumn{7}{|c|}{ Household characteristics } \\
\hline Size of the & 0.000489 & 0.0281 & 0.00299 & $-0.0261^{*}$ & 0.000214 & $-0.0479^{* * *}$ \\
\hline household & {$[0.00301]$} & [0.0229] & [0.00332] & [0.0156] & [0.00316] & [0.0182] \\
\hline $\begin{array}{l}\text { Dependence } \\
\text { ration }\end{array}$ & $\begin{array}{c}-0.0530^{* *} \\
{[0.0262]}\end{array}$ & $\begin{array}{l}0.0635 \\
{[0.171]}\end{array}$ & $\begin{array}{l}-0.0478^{*} \\
{[0.0245]}\end{array}$ & $\begin{array}{c}0.128 \\
{[0.122]}\end{array}$ & $\begin{array}{l}-0.0425^{*} \\
{[0.0254]}\end{array}$ & $\begin{array}{c}0.216 \\
{[0.174]}\end{array}$ \\
\hline $\begin{array}{l}\text { Age of the } \\
\text { head of }\end{array}$ & -0.000445 & 0.000449 & -0.000632 & -0.00391 & 0.000119 & -0.00315 \\
\hline household & [0.000495] & [0.00406] & {$[0.000580]$} & {$[0.00244]$} & [0.000497] & [0.00289] \\
\hline $\begin{array}{l}\text { Gender of } \\
\text { the head of } \\
\text { household, } 1 \\
\text { for male }\end{array}$ & -0.0189 & [0.0955] & -0.00509 & {$[0.0679]$} & 0.00538 & {$[0.0816]$} \\
\hline $\begin{array}{l}\text { Dummy, } \\
\text { head of } \\
\text { household } \\
\text { has higher }\end{array}$ & 0.0274 & 0.0608 & 0.0139 & 0.0685 & -0.00362 & 0.113 \\
\hline
\end{tabular}




\begin{tabular}{|c|c|c|c|c|c|c|}
\hline & $\begin{array}{c}\text { Received } \\
\text { income from } \\
\text { nonfarm self- } \\
\text { employment }\end{array}$ & $\begin{array}{c}\text { Logarithm } \\
\text { of self- } \\
\text { - employme } \\
\text { nt income } \\
\end{array}$ & $\begin{array}{l}\text { Received } \\
\text { public } \\
\text { nonfarm } \\
\text { salary } \\
\end{array}$ & $\begin{array}{c}\text { Logarithm of } \\
\text { public } \\
\text { nonfarm } \\
\text { salary } \\
\end{array}$ & $\begin{array}{c}\text { Received } \\
\text { commercial } \\
\text { nonfarm } \\
\text { salary }\end{array}$ & $\begin{array}{c}\text { Logarithm of } \\
\text { commercial } \\
\text { nonfarm } \\
\text { salary } \\
\end{array}$ \\
\hline \multicolumn{7}{|l|}{ education } \\
\hline \multicolumn{7}{|l|}{ Assets } \\
\hline $\begin{array}{l}\text { Number of } \\
\text { cattle by the } \\
\text { beginning of } \\
\text { the year }\end{array}$ & -0.000366 & $0.00656^{* *}$ & -0.000355 & 0.00203 & $-0.000770^{*}$ & $0.00809^{* * *}$ \\
\hline $\begin{array}{l}\text { Owned land, } \\
\text { ha }\end{array}$ & $\begin{array}{c}-0.0180^{* * *} \\
{[0.00620]}\end{array}$ & $\begin{array}{c}0.0752 \\
{[0.0771]}\end{array}$ & $\begin{array}{c}-0.00128 \\
{[0.00331]}\end{array}$ & $\begin{array}{l}-0.0123 \\
{[0.0148]}\end{array}$ & $\begin{array}{l}-0.0167^{* * *} \\
{[0.00438]}\end{array}$ & $\begin{array}{l}-0.0563 \\
{[0.0420]}\end{array}$ \\
\hline $\begin{array}{l}\text { Owned land } \\
\text { squared }\end{array}$ & $\begin{array}{c}0.000357^{* * *} \\
{[0.000118]}\end{array}$ & $\begin{array}{c}-0.00693 \\
{[0.0109]}\end{array}$ & $\begin{array}{c}2.84 \mathrm{E}-05 \\
{[7.07 \mathrm{e}-05]}\end{array}$ & $\begin{array}{c}0.000239 \\
{[0.000340]}\end{array}$ & $\begin{array}{c}0.000311^{* * *} \\
{[8.68 \mathrm{e}-05]}\end{array}$ & $\begin{array}{c}0.00555 \\
{[0.00359]}\end{array}$ \\
\hline \multicolumn{7}{|c|}{ Access to public utilities } \\
\hline $\begin{array}{l}\% \text { of having } \\
\text { access to }\end{array}$ & 0.000453 & $-0.00271^{*}$ & $0.000672^{* * *}$ & 0.00018 & $0.000644^{* *}$ & -0.00139 \\
\hline water & {$[0.000301]$} & {$[0.00161]$} & {$[0.000241]$} & [0.00106] & {$[0.000274]$} & [0.00183] \\
\hline $\begin{array}{l}\text { Time needed } \\
\text { to get to the }\end{array}$ & 0.000302 & -0.0194 & $0.00552^{* * *}$ & 0.00955 & $-0.00469^{* *}$ & $-0.0216^{*}$ \\
\hline bus stop & [0.00157] & {$[0.0151]$} & [0.00152] & {$[0.00735]$} & {$[0.00221]$} & [0.0117] \\
\hline \multicolumn{7}{|c|}{ Locational characteristics } \\
\hline $\begin{array}{l}\text { Basic land } \\
\text { tax at rayon } \\
\text { level, higher } \\
\text { tax better } \\
\text { quality of } \\
\text { land }\end{array}$ & $-0.000151^{* *}$ & {$[0.000381]$} & -0.000106 & -0.000217 & $-8.62 \mathrm{E}-05$ & 8.72E-05 \\
\hline $\begin{array}{l}\text { Size of rural } \\
\text { population }\end{array}$ & $0.000279^{* *}$ & -0.000331 & $-5.78 \mathrm{E}-05$ & $-0.000953^{*}$ & 8.82E-05 & -0.000251 \\
\hline in rayon & {$[0.000123]$} & {$[0.000764]$} & [0.000139] & {$[0.000562]$} & {$[0.000138]$} & [0.000809] \\
\hline $\begin{array}{l}\text { Distance } \\
\text { from rayon } \\
\text { centres to } \\
\text { regional } \\
\text { centres }\end{array}$ & $0.000303^{*}$ & $-0.00506^{* * *}$ & $0.000362^{* *}$ & -0.00105 & 0.000159 & $-0.00250^{*}$ \\
\hline $\begin{array}{l}\text { Dummy for } \\
\text { resort area in } \\
\text { Issykkul } \\
\text { region }\end{array}$ & [0.0845] & $0.429^{* * *}$ & $-0.0615^{* * *}$ & [0.163] & $0.293^{* * *}$ & {$[0.171]$} \\
\hline Pseudo R2 & 0.14 & & 0.2976 & & 0.2142 & \\
\hline Observations & 12069 & 940 & 12069 & 1662 & 12069 & 1373 \\
\hline $\begin{array}{l}\text { Log } \\
\text { likelihood }\end{array}$ & -2811.1605 & -860.9 & -3422.9649 & -1125.9112 & -3387.7254 & -1316.1605 \\
\hline $\begin{array}{l}\text { Log } \\
\text { likelihood of }\end{array}$ & & -5658.7174 & & -8296.8463 & & -7506.1895 \\
\hline
\end{tabular}




\begin{tabular}{|c|c|c|c|c|c|}
\hline & $\begin{array}{l}\text { Received Logarithm } \\
\text { income from of self- } \\
\text { nonfarm self- employme } \\
\text { employment nt income }\end{array}$ & $\begin{array}{l}\text { Received } \\
\text { public } \\
\text { nonfarm } \\
\text { salary }\end{array}$ & $\begin{array}{l}\text { Logarithm of } \\
\text { public } \\
\text { nonfarm } \\
\text { salary }\end{array}$ & $\begin{array}{l}\text { Received } \\
\text { commercial } \\
\text { nonfarm } \\
\text { salary }\end{array}$ & $\begin{array}{c}\text { Logarithm of } \\
\text { commercial } \\
\text { nonfarm } \\
\text { salary } \\
\end{array}$ \\
\hline \multicolumn{6}{|l|}{$\overline{\text { Tobita }}$} \\
\hline LR test for & 3973.3 & & 7495.9 & & 5604.6 \\
\hline $\begin{array}{l}\text { Tobit vs } \\
\text { double } \\
\text { hurdle } \\
\text { model }\end{array}$ & {$[0.00]^{\mathrm{b}}$} & & {$[0.00]$} & & [0.00] \\
\hline
\end{tabular}

Source: NSC, authors' estimation

Note: ${ }^{* *} \mathrm{p}<0.01,{ }^{* *} \mathrm{p}<0.05,{ }^{*} \mathrm{p}<0.1$ Regional and quarterly dummies are not reported. Weighted, robust, and clustered at the household level standard errors are in parentheses.

a The Tobit model can be tested against double hurdle model by computing the following likelihood ratio statistic $\lambda=2(\ln$ Lbinary $+\ln$ Ltruncated $-\ln$ LTobit), where $\lambda$ is distributed as chi-square with $\mathrm{R}$ degrees of freedom ( $\mathrm{R}$ is the number of independent variables including a constant). The Tobit model will be rejected in favour of double hurdle model if $\lambda$ exceeds the appropriate chi-square critical value (Green, 2000). Log likelihood obtained for regressions without weight and cluster options.

${ }^{b}$ Numbers in parentheses are associated with chi-square probabilities. Not rejection of Ho means rejection of restriction imposed by Tobit in favour of the double hurdle model.

\subsection{CONCLUSION}

High rural poverty, farming underemployment and widespread labour migration strengthen the importance of nonfarm activities for rural households in poor Central Asian countries where agriculture cannot alone bear the burden of poverty reduction in rural areas. This paper uses two representative household budget surveys from the Kyrgyz Republic to analyse factors influencing participation and returns from different types of nonfarm activities in 2005 and 2006.

At the aggregated level, the RNFE played important role both in terms of generated employment (37.8\% and 39.6\%) and income (31\% and 39\%) in 2005 and 2006 accordingly. By far most of employment in the RNFE is primary and generates a full workload due to the large share of formal employment in both private and public organisations. Public nonfarm employment accounts for about $37 \%$ of total rural nonfarm employment in the considered period.

Empirical analysis of the determinants of RNFE reveals that participation in nonfarm activities can be driven by insufficient land size, its poor quality, lack of cattle and the remoteness of the area of residence. These determinants point to a "push" nature of the RNFE when a poor asset base, insufficient agricultural income and market imperfections make individuals resort to nonfarm activities to supplement their meagre agricultural income or to smooth intra-seasonal cash flows and consumption. "Push" factors are found to be particularly important 
drivers of participation in nonfarm self-employment, employment by individuals and public employment, but are less important for jobs in private organisations. Moreover, it is often women who choose relatively badly paying nonfarm public employment, which probably provides more secure and stable incomes than agricultural income in areas with a poor agricultural base.

Besides "push" factors, we found some indications that "pull" factors can stimulate nonfarm activities. The size of land decreases the probability of participation in nonfarm activities at a decreasing rate suggesting a potentially positive contribution of land size to participation in nonfarm activities for households with ample land. Moreover, people in a famous resort area are more likely to engage in nonfarm activities which indicates importance of local "engines" of growth besides agriculture.

There are several important determinants which affect the capacity of an individual to participate in nonfarm activities. Better education is a crucial factor explaining the choice between nonfarm and farm activities. Higher education is also the main determining factor which allows people to participate in public and private nonfarm organisations, while participation in self-employment nonfarm activities requires only vocational or secondary education. The last important capacity variable is access to infrastructure, which stimulates participation in nonfarm employment over pure farming.

Interestingly, the determinants of nonfarm income given participation in nonfarm activities are not identical to the determinants of participation as such. Specifically, the number of cattle owned diminishes incentives to participate in the RNFE as an alternative source of income. However, it has a positive impact on the income from these activities given participation by allowing people to invest income from livestock in more profitable nonfarm activities. Higher education has a positive impact on nonfarm self-employment income, but does not affect participation since self-employment activities are mostly in informal sectors not requiring higher education. Larger transaction costs caused by remoteness of the area stimulate participation in the RNFE, but affect nonfarm earnings negatively.

Distributional analysis shows that earnings from nonfarm activities are more important for poor households generating about $50 \%$ of their total income consistent with the predominantly "push" character of the RNFE in Kyrgyzstan. Nonfarm per capita income is also slightly higher than farm income for the poorest quartile, but the opposite holds for richer households. Taking into account that education, access to infrastructure, size of cattle are found to have a positive impact on nonfarm earnings, inadequate access and possession of these capacity variables confines rural the poorest to low-productive nonfarm employment opportunities which probably offer a few pathways out of poverty. Therefore, equipping poor households to move towards better remunerative RNFE should be a priority. Investment in infrastructure, access to financial resources, skill building and enhancing of human capital along with local engines of growth can help to 
crease such a favourable environment and should be taken into account while designing and implementing rural policies in the Kyrgyz Republic.

\subsection{ANNEX}

Table A4.1. Descriptive statistics, 2005-2006

\begin{tabular}{|c|c|c|c|c|c|c|c|c|c|c|}
\hline & & & 2005 & & & & & 2006 & & \\
\hline & Obs & Mean & $\begin{array}{l}\text { Std. } \\
\text { Dev. }\end{array}$ & Min & Max & Obs & Mean & $\begin{array}{l}\text { Std. } \\
\text { Dev. }\end{array}$ & Min & Max \\
\hline $\begin{array}{l}\text { Dummy for } \\
\text { having nonfarm } \\
\text { salary }\end{array}$ & 12069 & 0.25 & 0.43 & 0.00 & 1.0 & 13408 & 0.27 & 0.44 & 0.00 & 1.0 \\
\hline $\begin{array}{l}\text { Logarithm of } \\
\text { nonfarm salary }\end{array}$ & 12069 & 2.04 & 3.54 & 0.00 & 10.71 & 13408 & 2.20 & 3.68 & 0.00 & 11.41 \\
\hline $\begin{array}{l}\text { Logarithm of } \\
\text { nonfarm self- } \\
\text { employment } \\
\text { income }\end{array}$ & 12069 & 0.66 & 2.26 & 0.00 & 10.78 & 13408 & 0.68 & 2.33 & 0.00 & 11.36 \\
\hline $\begin{array}{l}\text { Dummy for } \\
\text { having income } \\
\text { from nonfarm } \\
\text { self-employment }\end{array}$ & 12069 & 0.08 & 0.27 & 0.00 & 1.0 & 13408 & 0.08 & 0.27 & 0.00 & 1.00 \\
\hline $\begin{array}{l}\text { Dummy for } \\
\text { employment by } \\
\text { individuals }\end{array}$ & 12069 & 0.05 & 0.22 & 0.00 & 1.0 & 13408 & 0.07 & 0.25 & 0.00 & 1.0 \\
\hline $\begin{array}{l}\text { Dummy for } \\
\text { employment in } \\
\text { public nonfarm } \\
\text { organisations }\end{array}$ & 12069 & 0.15 & 0.36 & 0.00 & 1.0 & 13408 & 0.15 & 0.36 & 0.00 & 1.0 \\
\hline $\begin{array}{l}\text { Dummy for } \\
\text { employment in } \\
\text { private nonfarm } \\
\text { organisations }\end{array}$ & 12069 & 0.07 & 0.26 & 0.00 & 1.0 & 13408 & 0.07 & 0.25 & 0.00 & 1.0 \\
\hline Age & 12069 & 36 & 12 & 15 & 70 & 13408 & 37 & 13 & 15 & 70 \\
\hline Age squared & 12069 & 1463 & 943 & 225 & 4900 & 13408 & 1491 & 963 & 225 & 4900 \\
\hline $\begin{array}{l}\text { Dummy, } 1 \text { for } \\
\text { male }\end{array}$ & 12069 & 0.58 & 0.49 & 0.00 & 1.00 & 13408 & 0.58 & 0.49 & 0.00 & 1.00 \\
\hline $\begin{array}{l}\text { Dummy, } 1 \text { for } \\
\text { married }\end{array}$ & 12069 & 0.70 & 0.46 & 0.00 & 1.00 & 13408 & 0.70 & 0.46 & 0.00 & 1.00 \\
\hline $\begin{array}{l}\text { Dummy, } 1 \text { if the } \\
\text { head of household }\end{array}$ & 12069 & 0.36 & 0.48 & 0.00 & 1.00 & 13408 & 0.37 & 0.48 & 0.00 & 1.00 \\
\hline Dummy, Kyrgyz & 12069 & 0.83 & 0.38 & 0.00 & 1.00 & 13408 & 0.82 & 0.38 & 0.00 & 1.00 \\
\hline $\begin{array}{l}\text { Dummy, higher } \\
\text { education }\end{array}$ & 12069 & 0.12 & 0.33 & 0.00 & 1.00 & 13408 & 0.12 & 0.33 & 0.00 & 1.00 \\
\hline $\begin{array}{l}\text { Dummy, } \\
\text { vocational }\end{array}$ & 12069 & 0.22 & 0.42 & 0.00 & 1.00 & 13408 & 0.23 & 0.42 & 0.00 & 1.00 \\
\hline
\end{tabular}




\begin{tabular}{|c|c|c|c|c|c|c|c|c|c|c|}
\hline & & & 2005 & & & & & 2006 & & \\
\hline & Obs & Mean & $\begin{array}{l}\text { Std. } \\
\text { Dev. }\end{array}$ & Min & Max & Obs & Mean & $\begin{array}{l}\text { Std. } \\
\text { Dev. }\end{array}$ & Min & Max \\
\hline \multicolumn{11}{|l|}{$\overline{\text { education }}$} \\
\hline $\begin{array}{l}\text { Dummy, } \\
\text { secondary } \\
\text { education }\end{array}$ & 12069 & 0.55 & 0.50 & 0.00 & 1.00 & 13408 & 0.54 & 0.50 & 0.00 & 1.00 \\
\hline $\begin{array}{l}\text { Size of the } \\
\text { household }\end{array}$ & 12069 & 5.11 & 1.81 & 1.00 & 15.00 & 13408 & 5.01 & 1.78 & 1.00 & 18.00 \\
\hline $\begin{array}{l}\text { Dependence } \\
\text { ration }\end{array}$ & 12069 & 0.34 & 0.23 & 0.00 & 1.00 & 13408 & 0.33 & 0.23 & 0.00 & 1.00 \\
\hline $\begin{array}{l}\text { Age of the head of } \\
\text { household }\end{array}$ & 12069 & 50.46 & 12.76 & 21.00 & 105.00 & 13408 & 51.19 & 12.79 & 19.00 & 106.00 \\
\hline $\begin{array}{l}\text { Gender of the } \\
\text { head of } \\
\text { household, } 1 \text { for } \\
\text { male }\end{array}$ & 12069 & 0.82 & 0.38 & 0.00 & 1.00 & 13408 & 0.81 & 0.39 & 0.00 & 1.00 \\
\hline $\begin{array}{l}\text { Dummy, head of } \\
\text { household has } \\
\text { higher education }\end{array}$ & 12069 & 0.11 & 0.31 & 0.00 & 1.00 & 13408 & 0.11 & 0.31 & 0.00 & 1.00 \\
\hline $\begin{array}{l}\text { Number of cattle } \\
\text { by the beginning } \\
\text { of the year }\end{array}$ & 12069 & 14.23 & 37.11 & 0.00 & 729.00 & 13408 & 9.46 & 18.03 & 0.00 & 275.00 \\
\hline Owned land, ha & 12069 & 1.92 & 3.22 & 0.00 & 50.90 & 13408 & 1.97 & 3.58 & 0.00 & 50.90 \\
\hline $\begin{array}{l}\% \text { of having } \\
\text { access to water }\end{array}$ & 12069 & 83.73 & 27.23 & 0.00 & 100.00 & 13408 & 82.68 & 24.36 & 0.00 & 100.00 \\
\hline $\begin{array}{l}\text { Time needed to } \\
\text { get to the bus stop }\end{array}$ & 12069 & 13.24 & 4.12 & 6.00 & 32.00 & 13408 & 13.31 & 4.07 & 6.00 & 29.00 \\
\hline $\begin{array}{l}\text { Basic land tax at } \\
\text { rayon level, } \\
\text { higher tax better } \\
\text { quality of land }\end{array}$ & 12069 & 288.73 & 95.16 & 105.00 & 436.00 & 13408 & 289.27 & 95.35 & 105.00 & 436.00 \\
\hline $\begin{array}{l}\text { Size of rural } \\
\text { population in } \\
\text { rayon }\end{array}$ & 12069 & 92.95 & 60.51 & 12.60 & 298.10 & 13408 & 92.85 & 60.18 & 12.80 & 303.20 \\
\hline $\begin{array}{l}\text { Distance from } \\
\text { rayon centres to } \\
\text { regional centres }\end{array}$ & 12069 & 50.22 & 40.53 & 0.00 & 180.00 & 13408 & 49.87 & 41.01 & 0.00 & 180.00 \\
\hline $\begin{array}{l}\text { Dummy for resort } \\
\text { area in Issykkul } \\
\text { region }\end{array}$ & 12069 & 0.03 & 0.17 & 0 & 1 & 13408 & 0.03 & 0.18 & 0 & 1 \\
\hline $\begin{array}{l}\text { Dummy for } \\
\text { Issykkul region }\end{array}$ & 12069 & 0.15 & 0.36 & 0 & 1 & 13408 & 0.16 & 0.37 & 0 & 1 \\
\hline $\begin{array}{l}\text { Dummy for } \\
\text { Jalalabat region }\end{array}$ & 12069 & 0.15 & 0.36 & 0 & 1 & 13408 & 0.16 & 0.36 & 0 & 1 \\
\hline
\end{tabular}




\begin{tabular}{|c|c|c|c|c|c|c|c|c|c|c|}
\hline & & & 2005 & & & & & 2006 & & \\
\hline & Obs & Mean & $\begin{array}{l}\text { Std. } \\
\text { Dev. }\end{array}$ & Min & Max & Obs & Mean & $\begin{array}{l}\text { Std. } \\
\text { Dev. }\end{array}$ & Min & Max \\
\hline $\begin{array}{l}\text { Dummy for } \\
\text { Naryn region }\end{array}$ & 12069 & 0.13 & 0.34 & 0 & 1 & 13408 & 0.12 & 0.33 & 0 & 1 \\
\hline $\begin{array}{l}\text { Dummy for } \\
\text { Batken region }\end{array}$ & 12069 & 0.12 & 0.33 & 0 & 1 & 13408 & 0.12 & 0.32 & 0 & 1 \\
\hline $\begin{array}{l}\text { Dummy for Osh } \\
\text { region }\end{array}$ & 12069 & 0.14 & 0.35 & 0 & 1 & 13408 & 0.13 & 0.34 & 0 & 1 \\
\hline $\begin{array}{l}\text { Dummy for Talas } \\
\text { region }\end{array}$ & 12069 & 0.16 & 0.37 & 0 & 1 & 13408 & 0.16 & 0.36 & 0 & 1 \\
\hline $\begin{array}{l}\text { Dummy for the } \\
\text { first quarter }\end{array}$ & 12069 & 0.25 & 0.44 & 0 & 1 & 13408 & 0.24 & 0.43 & 0 & 1 \\
\hline $\begin{array}{l}\text { Dummy for the } \\
\text { second quarter }\end{array}$ & 12069 & 0.29 & 0.45 & 0 & 1 & 13408 & 0.26 & 0.44 & 0 & 1 \\
\hline $\begin{array}{l}\text { Dummy for the } \\
\text { third quarter }\end{array}$ & 12069 & 0.29 & 0.45 & 0 & 1 & 13408 & 0.26 & 0.44 & 0 & 1 \\
\hline
\end{tabular}

Table A4.2. Relative risk ratios for participation in nonfarm activities based on multinomial logit, 2006

\begin{tabular}{lcc}
\hline & $\begin{array}{c}\text { only } \\
\text { nonfarm } \\
\text { category }\end{array}$ & $\begin{array}{c}\text { farm and } \\
\text { nonfarm (mixed) } \\
\text { category }\end{array}$ \\
\hline Individual characteristics & $1.235^{* * *}$ & $1.363^{* * *}$ \\
Age & {$[0.0355]$} & {$[0.0460]$} \\
Age squared & $0.997^{* * *}$ & $0.996^{* * *}$ \\
Dummy, 1 for male & {$[0.000379]$} & {$[0.000429]$} \\
& 1.195 & 1.129 \\
Dummy, 1 for married & {$[0.141]$} & {$[0.143]$} \\
Dummy, head & $0.461^{* * *}$ & $0.747^{*}$ \\
Dummy, Kyrgyz & {$[0.0638]$} & {$[0.114]$} \\
Dummy, higher education & 1.046 & 1.179 \\
& {$[0.152]$} & {$[0.180]$} \\
Dummy, vocational education & $0.477^{* * *}$ & $0.405^{* * *}$ \\
Dummy, secondary education & {$[0.0742]$} & {$[0.0666]$} \\
Household characteristics & $13.34^{* * *}$ & $20.95^{* * *}$ \\
Size of the household & {$[3.511]$} & {$[6.405]$} \\
& $3.515^{* * *}$ & $5.314^{* * *}$ \\
& {$[0.725]$} & {$[1.350]$} \\
& 1.33 & $1.984^{* * *}$ \\
{$[0.495]$}
\end{tabular}




\begin{tabular}{|c|c|c|}
\hline & $\begin{array}{l}\text { only } \\
\text { nonfarm } \\
\text { category }\end{array}$ & $\begin{array}{c}\text { farm and } \\
\text { nonfarm (mixed) } \\
\text { category }\end{array}$ \\
\hline \multirow[t]{2}{*}{ Dependence ration } & $0.309^{* * *}$ & 0.986 \\
\hline & {$[0.0869]$} & [0.282] \\
\hline \multirow[t]{2}{*}{ Age of the head of household } & 0.993 & $0.990^{*}$ \\
\hline & {$[0.00516]$} & {$[0.00546]$} \\
\hline \multirow{2}{*}{$\begin{array}{l}\text { Gender of the head of household, } 1 \text { for } \\
\text { male }\end{array}$} & 0.957 & 0.835 \\
\hline & [0.146] & [0.135] \\
\hline \multirow{2}{*}{$\begin{array}{l}\text { Dummy, head of household has higher } \\
\text { education }\end{array}$} & 1.272 & 1.459 \\
\hline & [0.254] & [0.357] \\
\hline \multicolumn{3}{|l|}{ Assets } \\
\hline $\begin{array}{l}\text { Number of cattle by the beginning of the } \\
\text { year }\end{array}$ & $\begin{array}{l}0.958^{* * *} \\
{[0.00821]}\end{array}$ & $\begin{array}{c}0.998 \\
{[0.00366]}\end{array}$ \\
\hline Owned land, ha & $\begin{array}{l}0.776^{* * *} \\
{[0.0404]}\end{array}$ & $\begin{array}{l}0.786^{* * *} \\
{[0.0369]}\end{array}$ \\
\hline Owned land squared & $\begin{array}{l}1.005^{* * *} \\
{[0.00107]}\end{array}$ & $\begin{array}{c}1.005^{* * *} \\
{[0.000946]}\end{array}$ \\
\hline \multicolumn{3}{|l|}{ Access to public utilities } \\
\hline$\%$ of having access to water & $\begin{array}{l}1.014^{* * *} \\
{[0.00416]}\end{array}$ & $\begin{array}{l}1.018^{* * *} \\
{[0.00405]}\end{array}$ \\
\hline Time needed to get to the bus stop & $\begin{array}{c}1.014 \\
{[0.0218]}\end{array}$ & $\begin{array}{c}1.040^{*} \\
{[0.0217]}\end{array}$ \\
\hline \multicolumn{3}{|l|}{ Locational characteristics } \\
\hline $\begin{array}{l}\text { Basic land tax at rayon level, higher tax } \\
\text { better quality of land }\end{array}$ & $\begin{array}{c}0.997^{* * *} \\
{[0.000748]}\end{array}$ & $\begin{array}{c}1 \\
{[0.000741]}\end{array}$ \\
\hline Size of rural population in rayon & $\begin{array}{c}1.002 \\
{[0.00136]}\end{array}$ & $\begin{array}{c}1 \\
{[0.00155]}\end{array}$ \\
\hline \multirow{2}{*}{$\begin{array}{l}\text { Distance from rayon centres to regional } \\
\text { centres } \\
\text { Dummy for resort area in Issykkul region }\end{array}$} & $\begin{array}{c}1.003^{*} \\
{[0.00182]}\end{array}$ & $\begin{array}{l}1.010^{* * *} \\
{[0.00192]}\end{array}$ \\
\hline & $\begin{array}{c}5.013^{* * *} \\
{[1.685]}\end{array}$ & $\begin{array}{l}2.261^{* *} \\
{[0.750]}\end{array}$ \\
\hline Observations & \multicolumn{2}{|r|}{13408} \\
\hline Pseudo R & \multicolumn{2}{|r|}{0.2136} \\
\hline Wald chi2 & \multicolumn{2}{|r|}{1018.5} \\
\hline Probability >chi2 & \multicolumn{2}{|r|}{0.00} \\
\hline
\end{tabular}

Source: NSC, authors' estimation.

Notes: The base category is pure farming. ${ }^{* * *} \mathrm{p}<0.01,{ }^{* *} \mathrm{p}<0.05,{ }^{*} \mathrm{p}<0.1$ Intercepts, regional and quarterly dummies are not reported. Robust, clustered standard errors are in parentheses. 
Table A4.3. Marginal effects of the probit model for primary participation in rural nonfarm activities at the mean of explanatory variables, 2006

\begin{tabular}{|c|c|c|c|c|}
\hline & $\begin{array}{c}\text { Self- } \\
\text { employment }\end{array}$ & $\begin{array}{l}\text { Employmen } \\
\text { t by } \\
\text { individuals }\end{array}$ & $\begin{array}{l}\text { Employment } \\
\text { in private } \\
\text { organisations } \\
\end{array}$ & $\begin{array}{c}\text { Employment in } \\
\text { public } \\
\text { organisation } \\
\end{array}$ \\
\hline \multicolumn{5}{|l|}{ Individual characteristics } \\
\hline Age & $\begin{array}{l}0.0150^{* * *} \\
{[0.00282]}\end{array}$ & $\begin{array}{c}0.00265^{*} \\
{[0.00146]}\end{array}$ & $\begin{array}{l}0.00661^{* * *} \\
{[0.00177]}\end{array}$ & $\begin{array}{l}0.00820^{* * *} \\
{[0.00297]}\end{array}$ \\
\hline Age squared & $\begin{array}{c}-0.000183^{* * *} \\
{[3.73 e-05]}\end{array}$ & $\begin{array}{c}-5.74 \mathrm{e}-05^{* * *} \\
{[1.88 \mathrm{e}-05]}\end{array}$ & $\begin{array}{c}-7.21 \mathrm{e}-05^{* * *} \\
{[2.16 \mathrm{e}-05]}\end{array}$ & $\begin{array}{c}-8.01 \mathrm{e}-05^{* *} \\
{[3.78 \mathrm{e}-05]}\end{array}$ \\
\hline Dummy, 1 for male & $\begin{array}{c}0.0141 \\
{[0.0103]}\end{array}$ & $\begin{array}{l}0.0267^{* * *} \\
{[0.00623]}\end{array}$ & $\begin{array}{l}0.0381^{* * *} \\
{[0.00756]}\end{array}$ & $\begin{array}{l}-0.0907^{* * *} \\
{[0.0119]}\end{array}$ \\
\hline Dummy, 1 for married & $\begin{array}{l}-0.00608 \\
{[0.0131]}\end{array}$ & $\begin{array}{l}-0.0259^{* * *} \\
{[0.00892]}\end{array}$ & $\begin{array}{l}-0.00964 \\
{[0.0105]}\end{array}$ & $\begin{array}{l}-0.0430^{* *} \\
{[0.0171]}\end{array}$ \\
\hline Dummy, head & $\begin{array}{c}0.015 \\
{[0.0137]}\end{array}$ & $\begin{array}{c}0.0103 \\
{[0.00895]}\end{array}$ & $\begin{array}{c}-0.00171 \\
{[0.00922]}\end{array}$ & $\begin{array}{l}-0.0121 \\
{[0.0129]}\end{array}$ \\
\hline Dummy, Kyrgyz & $\begin{array}{l}-0.0339^{* *} \\
{[0.0168]}\end{array}$ & $\begin{array}{c}-0.0359^{* * *} \\
{[0.0113]}\end{array}$ & $\begin{array}{l}-0.0263^{* *} \\
{[0.0119]}\end{array}$ & $\begin{array}{l}0.00465 \\
{[0.0157]}\end{array}$ \\
\hline Dummy, higher education & $\begin{array}{l}-0.0463^{* * *} \\
{[0.0172]}\end{array}$ & $\begin{array}{l}-0.00625 \\
{[0.0128]}\end{array}$ & $\begin{array}{l}0.152^{* * *} \\
{[0.0437]}\end{array}$ & $\begin{array}{l}0.584^{* * *} \\
{[0.0659]}\end{array}$ \\
\hline $\begin{array}{l}\text { Dummy, vocational } \\
\text { education }\end{array}$ & $\begin{array}{c}0.0207 \\
{[0.0229]}\end{array}$ & $\begin{array}{c}0.0187 \\
{[0.0125]}\end{array}$ & $\begin{array}{c}0.0743^{* * *} \\
{[0.0237]}\end{array}$ & $\begin{array}{l}0.228^{* * *} \\
{[0.0515]}\end{array}$ \\
\hline $\begin{array}{l}\text { Dummy, secondary } \\
\text { education }\end{array}$ & $\begin{array}{c}0.0126 \\
{[0.0193]}\end{array}$ & $\begin{array}{c}0.0141 \\
{[0.00899]}\end{array}$ & $\begin{array}{l}0.0286^{* *} \\
{[0.0131]}\end{array}$ & $\begin{array}{c}0.0312 \\
{[0.0252]}\end{array}$ \\
\hline \multicolumn{5}{|l|}{ Household characteristics } \\
\hline Size of the household & $\begin{array}{c}0.00142 \\
{[0.00279]}\end{array}$ & $\begin{array}{c}-0.00151 \\
{[0.00217]}\end{array}$ & $\begin{array}{c}-0.0019 \\
{[0.00219]}\end{array}$ & $\begin{array}{c}0.0022 \\
{[0.00299]}\end{array}$ \\
\hline Dependence ration & $\begin{array}{l}-0.0337 \\
{[0.0266]}\end{array}$ & $\begin{array}{l}0.00271 \\
{[0.0152]}\end{array}$ & $\begin{array}{l}-0.0106 \\
{[0.0167]}\end{array}$ & $\begin{array}{c}-0.0828^{* * *} \\
{[0.0257]}\end{array}$ \\
\hline $\begin{array}{l}\text { Age of the head of } \\
\text { household }\end{array}$ & $\begin{array}{c}9.76 \mathrm{E}-05 \\
{[0.000451]}\end{array}$ & $\begin{array}{c}0.000268 \\
{[0.000282]}\end{array}$ & $\begin{array}{c}6.75 \mathrm{E}-07 \\
{[0.000334]}\end{array}$ & $\begin{array}{l}-0.00138^{* * *} \\
{[0.000508]}\end{array}$ \\
\hline $\begin{array}{l}\text { Gender of the head of } \\
\text { household, } 1 \text { for male }\end{array}$ & $\begin{array}{l}0.00157 \\
{[0.0131]}\end{array}$ & $\begin{array}{l}-0.00476 \\
{[0.00799]}\end{array}$ & $\begin{array}{l}-0.00264 \\
{[0.0106]}\end{array}$ & $\begin{array}{l}0.00483 \\
{[0.0144]}\end{array}$ \\
\hline $\begin{array}{l}\text { Dummy, head of household } \\
\text { has higher education } \\
\text { Assets }\end{array}$ & $\begin{array}{c}0.0362 \\
{[0.0311]}\end{array}$ & $\begin{array}{c}-0.000957 \\
{[0.0136]}\end{array}$ & $\begin{array}{l}-0.0015 \\
{[0.0106]}\end{array}$ & $\begin{array}{c}0.0171 \\
{[0.0186]}\end{array}$ \\
\hline $\begin{array}{l}\text { Number of cattle by the } \\
\text { beginning of the year }\end{array}$ & $\begin{array}{c}-0.00083 \\
{[0.000583]}\end{array}$ & $\begin{array}{l}-0.00255^{* * *} \\
{[0.000527]}\end{array}$ & $\begin{array}{c}-0.00041 \\
{[0.000267]}\end{array}$ & $\begin{array}{l}-0.000503 \\
{[0.000329]}\end{array}$ \\
\hline Owned land, ha & $\begin{array}{l}-0.0217^{* * *} \\
{[0.00525]}\end{array}$ & $\begin{array}{l}-0.00728^{* *} \\
{[0.00289]}\end{array}$ & $\begin{array}{l}-0.00652^{*} \\
{[0.00334]}\end{array}$ & $\begin{array}{c}-0.00103 \\
{[0.00319]}\end{array}$ \\
\hline Owned land squared & $\begin{array}{c}0.000381^{* * *} \\
{[0.000102]}\end{array}$ & $\begin{array}{l}0.000144^{* *} \\
{[5.97 \mathrm{e}-05]}\end{array}$ & $\begin{array}{l}0.000110^{*} \\
{[6.03 e-05]}\end{array}$ & $\begin{array}{c}2.81 \mathrm{E}-05 \\
{[7.08 \mathrm{e}-05]}\end{array}$ \\
\hline \multicolumn{5}{|l|}{ Access to public utilities } \\
\hline$\%$ of having access to water & [0.000402] & [0.000239] & {$[0.000230]$} & [0.000305] \\
\hline
\end{tabular}




\begin{tabular}{lcccc}
\hline & $\begin{array}{c}\text { Self- } \\
\text { employment }\end{array}$ & $\begin{array}{c}\text { Employmen } \\
\text { t by } \\
\text { individuals }\end{array}$ & $\begin{array}{c}\text { Employment } \\
\text { in private } \\
\text { organisations }\end{array}$ & $\begin{array}{c}\text { Employment in } \\
\text { public } \\
\text { organisation }\end{array}$ \\
\hline Time needed to get to the & $0.00334^{*}$ & 0.000707 & -0.00206 & $0.00387^{* *}$ \\
bus stop & {$[0.00199]$} & {$[0.00128]$} & {$[0.00166]$} & {$[0.00171]$} \\
Locational characteristics & & & & \\
Basic land tax at rayon level, & $-0.000139^{* *}$ & $-4.03 \mathrm{E}-05$ & $-5.38 \mathrm{E}-05$ & $-0.000182^{* * *}$ \\
Size of rural population in & {$[6.20 \mathrm{e}-05]$} & {$[3.76 \mathrm{e}-05]$} & {$[5.43 \mathrm{e}-05]$} & {$[6.82 \mathrm{e}-05]$} \\
rayon & 0.0002 & $0.000165^{* *}$ & -0.000149 & $-5.86 \mathrm{E}-05$ \\
Distance from rayon centres & {$[0.000126]$} & {$[8.21 \mathrm{e}-05]$} & {$[0.000106]$} & {$[0.000127]$} \\
to regional centres & 0.00011 & $0.000337^{* * *}$ & $-9.54 \mathrm{E}-05$ & $0.000261^{*}$ \\
Dummy for resort area in & {$[0.000180]$} & {$[0.000108]$} & {$[0.000120]$} & {$[0.000155]$} \\
Issykkul region & 0.115 & $0.0481^{*}$ & $0.267^{* * *}$ & $-0.0491^{* * *}$ \\
Observations & {$[0.0712]$} & {$[0.0292]$} & {$[0.0742]$} & {$[0.0152]$} \\
Pseudo R2 & 13408 & 13408 & 13408 & 13408 \\
Wald chi2(33) & 0.128 & 0.22 & 0.16 & 0.307 \\
obs. P & 194.21 & 352.2 & 293 & 633.65 \\
pred. P & 0.099 & 0.08 & 0.07 & 0.136 \\
\hline
\end{tabular}

Source: NSC, authors' estimation

Note: ${ }^{* * *} \mathrm{p}<0.01,{ }^{* *} \mathrm{p}<0.05,{ }^{*} \mathrm{p}<0.1$ Regional and quarterly dummies are not reported. Robust and clustered standard errors are in parentheses.

Table A4.4. Double hurdle model, marginal effects after probit and results after truncated regression for logarithm of income from rural nonfarm activities, 2006

\begin{tabular}{|c|c|c|c|c|c|c|}
\hline & $\begin{array}{l}\text { Received } \\
\text { income } \\
\text { from } \\
\text { nonfarm } \\
\text { self- } \\
\text { employme } \\
\text { nt } \\
\end{array}$ & $\begin{array}{l}\text { Logarithm } \\
\text { of self- } \\
\text { employme } \\
\text { nt income }\end{array}$ & $\begin{array}{l}\text { Received } \\
\text { public } \\
\text { nonfarm } \\
\text { salary }\end{array}$ & $\begin{array}{l}\text { Logarith } \\
\text { m of } \\
\text { public } \\
\text { nonfarm } \\
\text { salary }\end{array}$ & $\begin{array}{c}\text { Received } \\
\text { commerci } \\
\text { al } \\
\text { nonfarm } \\
\text { salary }\end{array}$ & $\begin{array}{c}\text { Logarith } \\
\text { m of } \\
\text { commerc } \\
\text { ial } \\
\text { nonfarm } \\
\text { salary }\end{array}$ \\
\hline \multicolumn{7}{|c|}{ Individual characteristics } \\
\hline Age & $\begin{array}{l}0.0144^{* * *} \\
{[0.00276]}\end{array}$ & $\begin{array}{c}-0.000529 \\
{[0.0189]}\end{array}$ & $\begin{array}{c}0.00991^{* * *} \\
{[0.00270]}\end{array}$ & $\begin{array}{c}0.0491^{* * *} \\
{[0.0142]}\end{array}$ & $\begin{array}{c}0.00874^{* * *} \\
{[0.00267]}\end{array}$ & $\begin{array}{c}0.0114 \\
{[0.0146]}\end{array}$ \\
\hline Age squared & $\begin{array}{c}-0.000176^{* * *} \\
{[3.64 \mathrm{e}-05]}\end{array}$ & $\begin{array}{c}8.16 \mathrm{E}-06 \\
{[0.000226]}\end{array}$ & $\begin{array}{c}-0.000100^{* * *} \\
{[3.43 e-05]}\end{array}$ & $\begin{array}{c}-0.000557^{* * *} \\
{[0.000184]}\end{array}$ & $\begin{array}{c}-0.000126^{* * *} \\
{[3.34 \mathrm{e}-05]}\end{array}$ & $\begin{array}{c}-0.000236 \\
{[0.000191]}\end{array}$ \\
\hline $\begin{array}{l}\text { Dummy, } 1 \\
\text { for male }\end{array}$ & $\begin{array}{c}0.0116 \\
{[0.00995]}\end{array}$ & $\begin{array}{l}0.204^{* * *} \\
{[0.0762]}\end{array}$ & $\begin{array}{c}-0.0833^{* * *} \\
{[0.0106]}\end{array}$ & $\begin{array}{l}0.00874 \\
{[0.0655]}\end{array}$ & $\begin{array}{c}0.0761^{* * *} \\
{[0.0112]}\end{array}$ & $\begin{array}{l}0.294^{* * *} \\
{[0.0618]}\end{array}$ \\
\hline $\begin{array}{l}\text { Dummy, } 1 \\
\text { for married }\end{array}$ & $\begin{array}{l}-0.00112 \\
{[0.0126]}\end{array}$ & $\begin{array}{c}0.106 \\
{[0.0878]}\end{array}$ & $\begin{array}{l}-0.0289^{*} \\
{[0.0150]}\end{array}$ & $\begin{array}{c}0.0564 \\
{[0.0718]}\end{array}$ & $\begin{array}{c}-0.0459^{* * *} \\
{[0.0157]}\end{array}$ & $\begin{array}{c}0.147^{* *} \\
{[0.0657]}\end{array}$ \\
\hline Dummy, & 0.0183 & 0.0485 & -0.000981 & $0.126^{*}$ & 0.0129 & $0.138^{*}$ \\
\hline head & {$[0.0133]$} & [0.106] & {$[0.0114]$} & {$[0.0728]$} & {$[0.0156]$} & {$[0.0778]$} \\
\hline Dummy, & $-0.0313^{* *}$ & -0.0716 & 0.00532 & 0.0451 & $-0.0902^{* * *}$ & $-0.168^{* *}$ \\
\hline Kyrgyz & [0.0159] & [0.0779] & {$[0.0136]$} & {$[0.0632]$} & [0.0186] & [0.0657] \\
\hline
\end{tabular}




\begin{tabular}{|c|c|c|c|c|c|c|}
\hline & $\begin{array}{l}\text { Received } \\
\text { income } \\
\text { from } \\
\text { nonfarm } \\
\text { self- } \\
\text { employme } \\
\text { nt }\end{array}$ & $\begin{array}{l}\text { Logarithm } \\
\text { of self- } \\
\text { employme } \\
\text { nt income }\end{array}$ & $\begin{array}{l}\text { Received } \\
\text { public } \\
\text { nonfarm } \\
\text { salary }\end{array}$ & $\begin{array}{l}\text { Logarith } \\
\text { m of } \\
\text { public } \\
\text { nonfarm } \\
\text { salary }\end{array}$ & $\begin{array}{c}\text { Received } \\
\text { commerci } \\
\text { al } \\
\text { nonfarm } \\
\text { salary }\end{array}$ & $\begin{array}{c}\text { Logarith } \\
\text { m of } \\
\text { commerc } \\
\text { ial } \\
\text { nonfarm } \\
\text { salary }\end{array}$ \\
\hline $\begin{array}{l}\text { Dummy, } \\
\text { higher }\end{array}$ & $-0.0479 * * *$ & 0.263 & $0.571^{* * *}$ & $1.241^{* * *}$ & $0.128^{* * *}$ & $0.271^{* *}$ \\
\hline education & [0.0157] & {$[0.173]$} & [0.0703] & {$[0.236]$} & {$[0.0401]$} & {$[0.115]$} \\
\hline $\begin{array}{l}\text { Dummy, } \\
\text { vocational }\end{array}$ & 0.0215 & $0.275^{* *}$ & $0.225^{* * *}$ & $0.934^{* * *}$ & $0.0831^{* * *}$ & $0.172^{*}$ \\
\hline education & {$[0.0228]$} & {$[0.128]$} & {$[0.0526]$} & {$[0.238]$} & {$[0.0260]$} & {$[0.0945]$} \\
\hline $\begin{array}{l}\text { Dummy, } \\
\text { secondary }\end{array}$ & 0.0119 & 0.154 & $0.0389^{*}$ & $0.597^{* *}$ & $0.0360^{* *}$ & 0.137 \\
\hline education & {$[0.0192]$} & {$[0.131]$} & {$[0.0231]$} & {$[0.243]$} & {$[0.0182]$} & {$[0.0841]$} \\
\hline \multicolumn{7}{|c|}{ Household characteristics } \\
\hline Size of the & 0.00141 & $0.0728^{* * *}$ & 0.00266 & -0.0191 & -0.00305 & $-0.0383^{* *}$ \\
\hline household & {$[0.00271]$} & [0.0212] & {$[0.00253]$} & {$[0.0151]$} & {$[0.00358]$} & {$[0.0160]$} \\
\hline $\begin{array}{l}\text { Dependence } \\
\text { ration }\end{array}$ & $\begin{array}{c}-0.0323 \\
{[0.0255]}\end{array}$ & $\begin{array}{l}-0.208 \\
{[0.131]}\end{array}$ & $\begin{array}{c}-0.0748^{* * *} \\
{[0.0228]}\end{array}$ & $\begin{array}{c}-0.0218 \\
{[0.127]}\end{array}$ & $\begin{array}{l}-0.00915 \\
{[0.0255]}\end{array}$ & $\begin{array}{c}0.357^{* * *} \\
{[0.137]}\end{array}$ \\
\hline $\begin{array}{l}\text { Age of the } \\
\text { head of }\end{array}$ & 0.000294 & 0.00113 & $-0.000970^{* *}$ & -0.00203 & 0.000244 & 0.000195 \\
\hline household & [0.000429] & {$[0.00331]$} & {$[0.000450]$} & {$[0.00233]$} & {$[0.000525]$} & [0.00235] \\
\hline $\begin{array}{l}\text { Gender of } \\
\text { the head of } \\
\text { household, } 1\end{array}$ & 0.000117 & 0.017 & -0.00381 & -0.0157 & -0.00625 & 0.0317 \\
\hline for male & [0.0129] & [0.0861] & [0.0137] & {$[0.0734]$} & [0.0156] & [0.0692] \\
\hline $\begin{array}{l}\text { Dummy, } \\
\text { head of } \\
\text { household } \\
\text { has higher }\end{array}$ & 0.0399 & 0.088 & 0.0164 & $0.104^{* *}$ & 0.00754 & $0.208^{* * *}$ \\
\hline $\begin{array}{l}\text { education } \\
\text { Assets }\end{array}$ & [0.0308] & [0.127] & {$[0.0163]$} & [0.0490] & [0.0191] & {$[0.0803]$} \\
\hline $\begin{array}{l}\text { Number of } \\
\text { cattle by the } \\
\text { beginning of }\end{array}$ & -0.000795 & 0.00362 & -0.000467 & 0.00156 & $-0.00223^{* * *}$ & 0.00425 \\
\hline the year & [0.000547] & [0.00413] & {$[0.000289]$} & {$[0.00120]$} & {$[0.000598]$} & {$[0.00301]$} \\
\hline $\begin{array}{l}\text { Owned land, } \\
\text { ha }\end{array}$ & $\begin{array}{c}-0.0214^{* * *} \\
{[0.00510]}\end{array}$ & $\begin{array}{c}-0.113^{*} \\
{[0.0587]}\end{array}$ & $\begin{array}{l}-0.000369 \\
{[0.00279]}\end{array}$ & $\begin{array}{l}-0.00815 \\
{[0.0163]}\end{array}$ & $\begin{array}{c}-0.0180^{* * *} \\
{[0.00454]}\end{array}$ & $\begin{array}{c}0.0138 \\
{[0.0272]}\end{array}$ \\
\hline $\begin{array}{l}\text { Owned land } \\
\text { squared }\end{array}$ & $\begin{array}{c}0.000378^{* * *} \\
{[9.73 \mathrm{e}-05]}\end{array}$ & $\begin{array}{c}0.0126 \\
{[0.00773]}\end{array}$ & $\begin{array}{l}1.72 \mathrm{E}-05 \\
{[6.24 \mathrm{e}-05]}\end{array}$ & $\begin{array}{c}0.000155 \\
{[0.000344]}\end{array}$ & $\begin{array}{c}0.000341^{* * * *} \\
{[9.23 e-05]}\end{array}$ & $\begin{array}{c}-0.000457 \\
{[0.000599]}\end{array}$ \\
\hline \multicolumn{7}{|c|}{ Access to public utilities } \\
\hline $\begin{array}{l}\% \text { of having } \\
\text { access to }\end{array}$ & $\begin{array}{l}0.00118^{* * *} \\
{[0.000411]}\end{array}$ & $\begin{array}{l}-0.00269 \\
{[0.00200]}\end{array}$ & $\begin{array}{l}0.000560^{* *} \\
{[0.000265]}\end{array}$ & $\begin{array}{c}-0.000293 \\
{[0.00125]}\end{array}$ & $\begin{array}{l}0.00103^{* * *} \\
{[0.000392]}\end{array}$ & $\begin{array}{l}-0.00286 \\
{[0.00250]}\end{array}$ \\
\hline
\end{tabular}




\begin{tabular}{|c|c|c|c|c|c|c|}
\hline & $\begin{array}{c}\text { Received } \\
\text { income } \\
\text { from } \\
\text { nonfarm } \\
\text { self- } \\
\text { employme } \\
\text { nt }\end{array}$ & $\begin{array}{l}\text { Logarithm } \\
\text { of self- } \\
\text { employme } \\
\text { nt income }\end{array}$ & $\begin{array}{l}\text { Received } \\
\text { public } \\
\text { nonfarm } \\
\text { salary }\end{array}$ & $\begin{array}{l}\text { Logarith } \\
\text { m of } \\
\text { public } \\
\text { nonfarm } \\
\text { salary }\end{array}$ & $\begin{array}{l}\text { Received } \\
\text { commerci } \\
\text { al } \\
\text { nonfarm } \\
\text { salary }\end{array}$ & $\begin{array}{l}\text { Logarith } \\
\text { m of } \\
\text { commerc } \\
\text { ial } \\
\text { nonfarm } \\
\text { salary }\end{array}$ \\
\hline \multicolumn{7}{|l|}{ water } \\
\hline $\begin{array}{l}\text { Time needed } \\
\text { to get to the }\end{array}$ & 0.00256 & -0.00446 & $0.00364^{* *}$ & $0.0164^{* *}$ & -0.0029 & $-0.0218^{* *}$ \\
\hline bus stop & [0.00196] & {$[0.00851]$} & [0.00149] & [0.00737] & {$[0.00252]$} & [0.00997] \\
\hline \multicolumn{7}{|c|}{ Locational characteristics } \\
\hline $\begin{array}{l}\text { Basic land } \\
\text { tax at rayon }\end{array}$ & $-9.40 \mathrm{E}-05$ & $-0.000790^{* *}$ & $-0.000168^{* * *}$ & -0.000178 & $-0.000172^{* *}$ & 0.000174 \\
\hline level & [5.88e-05] & [0.000337] & [6.02e-05] & {$[0.000326]$} & [7.83e-05] & {$[0.000402]$} \\
\hline $\begin{array}{l}\text { Size of rural } \\
\text { population }\end{array}$ & 0.000187 & $-0.00149^{* *}$ & $-1.90 \mathrm{E}-05$ & $-7.22 \mathrm{E}-05$ & $-3.43 \mathrm{E}-05$ & -0.000695 \\
\hline in rayon & {$[0.000125]$} & {$[0.000634]$} & [0.000111] & {$[0.000543]$} & [0.000149] & {$[0.000696]$} \\
\hline $\begin{array}{l}\text { Distance } \\
\text { from rayon } \\
\text { centres to } \\
\text { regional } \\
\text { centres }\end{array}$ & 0.000129 & $-0.00362^{* * *}$ & $0.000278^{* *}$ & -0.000119 & $0.000316^{*}$ & $-0.00209^{*}$ \\
\hline $\begin{array}{l}\text { Dummy for } \\
\text { resort area in } \\
\text { Issykkul } \\
\text { region } \\
\end{array}$ & {$[0.0634]$} & $0.266^{*}$ & $-0.0402^{* * *}$ & 0.0416 & $0.310^{* * *}$ & $0.646^{* * *}$ \\
\hline Pseudo R2 & 0.128 & & 0.3109 & & 0.2111 & \\
\hline Observations & 13408 & 1071 & 13408 & 1836 & 13408 & 1720 \\
\hline $\begin{array}{l}\text { Log } \\
\text { likelihood }\end{array}$ & -3259.1 & -970.2 & -3693.9538 & -1252.515 & -4125.0408 & -1541.8542 \\
\hline $\begin{array}{l}\text { Log } \\
\text { likelihood of } \\
\text { Tobit }^{\mathrm{a}}\end{array}$ & & -6520.1416 & & -9107.8828 & & -9306.3868 \\
\hline $\begin{array}{l}\text { LR test for } \\
\text { Tobit vs } \\
\text { double } \\
\text { hurdle }\end{array}$ & & 4581.7 & & 8322.8 & & 7279.0 \\
\hline model & & {$[0.00]$} & & {$[0.00]$} & & {$[0.00]$} \\
\hline
\end{tabular}

Source: NSC, authors' estimation

Note: ${ }^{* *} \mathrm{p}<0.01,{ }^{* *} \mathrm{p}<0.05,{ }^{*} \mathrm{p}<0.1$ Regional and quarterly dummies are not reported. Robust and clustered standard errors are in parentheses.

a The Tobit model can be tested against double hurdle model by computing the following likelihood ratio statistic $\lambda=2(\ln$ Lbinary $+\ln$ Ltruncated $-\ln$ LTobit), where $\lambda$ is distributed as chi-square with $R$ degrees of freedom ( $R$ is the number of independent variables including a constant). The Tobit model will be rejected in favour of double hurdle 
model if $\lambda$ exceeds the appropriate chi-square critical value (Green, 2000). Log likelihood obtained for regressions without weight and cluster options.

b Numbers in parentheses are associated with chi-square probabilities. Not rejection of Ho means rejection of restriction imposed by Tobit in favour of the double hurdle model.

Table A4.5. Relative risk ratios for participation in nonfarm activities based on multinomial logit, without potentially endogenous variables, 2005

\begin{tabular}{|c|c|c|c|c|c|c|}
\hline & $\begin{array}{c}\text { only } \\
\text { nonfarm }\end{array}$ & $\begin{array}{c}\text { farm and } \\
\text { nonfarm } \\
\text { (mixed) }\end{array}$ & $\begin{array}{c}\text { only } \\
\text { nonfarm }\end{array}$ & $\begin{array}{c}\text { farm and } \\
\text { nonfarm } \\
\text { (mixed) }\end{array}$ & $\begin{array}{c}\text { only } \\
\text { nonfarm }\end{array}$ & $\begin{array}{c}\text { farm and } \\
\text { nonfarm } \\
\text { (mixed) }\end{array}$ \\
\hline & \multicolumn{2}{|c|}{$\begin{array}{c}\text { Land and cattle } \\
\text { excluded }\end{array}$} & \multicolumn{2}{|c|}{ Cattle excluded } & \multicolumn{2}{|c|}{ Land excluded } \\
\hline \multicolumn{7}{|c|}{ Individual characteristics } \\
\hline Age & $\begin{array}{l}1.243^{* * *} \\
{[0.0389]}\end{array}$ & $\begin{array}{l}1.242^{* * *} \\
{[0.0399]}\end{array}$ & $\begin{array}{l}1.245^{* * *} \\
{[0.0400]}\end{array}$ & $\begin{array}{l}1.244^{* * *} \\
{[0.0402]}\end{array}$ & $\begin{array}{l}1.245^{* * *} \\
{[0.0393]}\end{array}$ & $\begin{array}{l}1.243^{* * *} \\
{[0.0399]}\end{array}$ \\
\hline Age squared & $\begin{array}{c}0.997^{* * *} \\
{[0.000409]}\end{array}$ & $\begin{array}{c}0.997^{* * *} \\
{[0.000406]}\end{array}$ & $\begin{array}{c}0.997^{* * *} \\
{[0.000420]}\end{array}$ & $\begin{array}{c}0.997^{* * *} \\
{[0.000409]}\end{array}$ & $\begin{array}{c}0.997^{* * *} \\
{[0.000414]}\end{array}$ & $\begin{array}{c}0.997^{* * *} \\
{[0.000406]}\end{array}$ \\
\hline $\begin{array}{l}\text { Dummy, } 1 \text { for } \\
\text { male }\end{array}$ & $\begin{array}{c}1.171 \\
{[0.141]}\end{array}$ & $\begin{array}{c}1.002 \\
{[0.126]}\end{array}$ & $\begin{array}{c}1.223^{*} \\
{[0.150]}\end{array}$ & $\begin{array}{c}1.04 \\
{[0.133]}\end{array}$ & $\begin{array}{c}1.18 \\
{[0.143]}\end{array}$ & $\begin{array}{c}1.006 \\
{[0.127]}\end{array}$ \\
\hline $\begin{array}{l}\text { Dummy, } 1 \text { for } \\
\text { married }\end{array}$ & $\begin{array}{l}0.530^{* * *} \\
{[0.0794]}\end{array}$ & $\begin{array}{c}1.17 \\
{[0.179]}\end{array}$ & $\begin{array}{l}0.519^{* * *} \\
{[0.0787]}\end{array}$ & $\begin{array}{c}1.159 \\
{[0.178]}\end{array}$ & $\begin{array}{l}0.511^{* * *} \\
{[0.0779]}\end{array}$ & $\begin{array}{c}1.17 \\
{[0.178]}\end{array}$ \\
\hline Dummy, head & 1.046 & $1.303^{*}$ & 0.995 & 1.241 & 1.033 & $1.296^{*}$ \\
\hline Dummy, Kyrgyz & $\begin{array}{c}{[0.159]} \\
0.427^{* * *}\end{array}$ & $\begin{array}{c}{[0.200]} \\
0.456^{* * *}\end{array}$ & $\begin{array}{c}{[0.152]} \\
0.519^{* * *}\end{array}$ & $\begin{array}{c}{[0.193]} \\
0.547^{* * *}\end{array}$ & $\begin{array}{c}{[0.157]} \\
0.488^{* * *}\end{array}$ & $\begin{array}{c}{[0.199]} \\
0.485^{* * *}\end{array}$ \\
\hline & [0.0692] & [0.0713] & [0.0842] & [0.0866] & [0.0811] & [0.0777] \\
\hline $\begin{array}{l}\text { Dummy, higher } \\
\text { education } \\
\text { (university }\end{array}$ & $18.01^{* * *}$ & $13.23^{* * *}$ & $19.93^{* * *}$ & $14.07^{* * *}$ & $20.08^{* * *}$ & $13.87^{* * *}$ \\
\hline degree) & {$[4.700]$} & [3.996] & [5.400] & {$[4.372]$} & [5.363] & {$[4.214]$} \\
\hline $\begin{array}{l}\text { Dummy, } \\
\text { vocational }\end{array}$ & $3.758^{* * *}$ & $3.138^{* * *}$ & $3.800^{* * *}$ & $3.075^{* * *}$ & $3.858^{* * *}$ & $3.157^{* * *}$ \\
\hline education & [0.757] & [0.815] & [0.798] & {$[0.820]$} & {$[0.775]$} & [0.819] \\
\hline $\begin{array}{l}\text { Dummy, } \\
\text { secondary }\end{array}$ & 1.371 & 1.141 & $1.405^{*}$ & 1.141 & $1.402^{*}$ & 1.148 \\
\hline education & {$[0.264]$} & [0.297] & {$[0.282]$} & [0.303] & {$[0.268]$} & {$[0.298]$} \\
\hline Household characteris & stics & & & & & \\
\hline Size of the & 1.018 & 0.948 & 1.052 & 0.983 & 1.029 & 0.952 \\
\hline household & [0.0408] & [0.0340] & [0.0423] & [0.0346] & [0.0412] & {$[0.0339]$} \\
\hline Dependence ration & $0.341^{* * *}$ & 0.652 & $0.295^{* * *}$ & $0.542^{* *}$ & $0.341^{* * *}$ & 0.642 \\
\hline & [0.108] & [0.179] & {$[0.0940]$} & [0.148] & [0.107] & [0.175] \\
\hline $\begin{array}{l}\text { Age of the head of } \\
\text { household }\end{array}$ & $\begin{array}{c}0.987^{* *} \\
{[0.00563]}\end{array}$ & $\begin{array}{c}0.987^{* *} \\
{[0.00571]}\end{array}$ & $\begin{array}{c}0.989^{*} \\
{[0.00568]}\end{array}$ & $\begin{array}{c}0.989^{*} \\
{[0.00576]}\end{array}$ & $\begin{array}{c}0.992 \\
{[0.00562]}\end{array}$ & $\begin{array}{c}0.990^{*} \\
{[0.00587]}\end{array}$ \\
\hline Gender of the & 0.776 & 0.759 & 0.803 & 0.778 & 0.865 & 0.8 \\
\hline
\end{tabular}




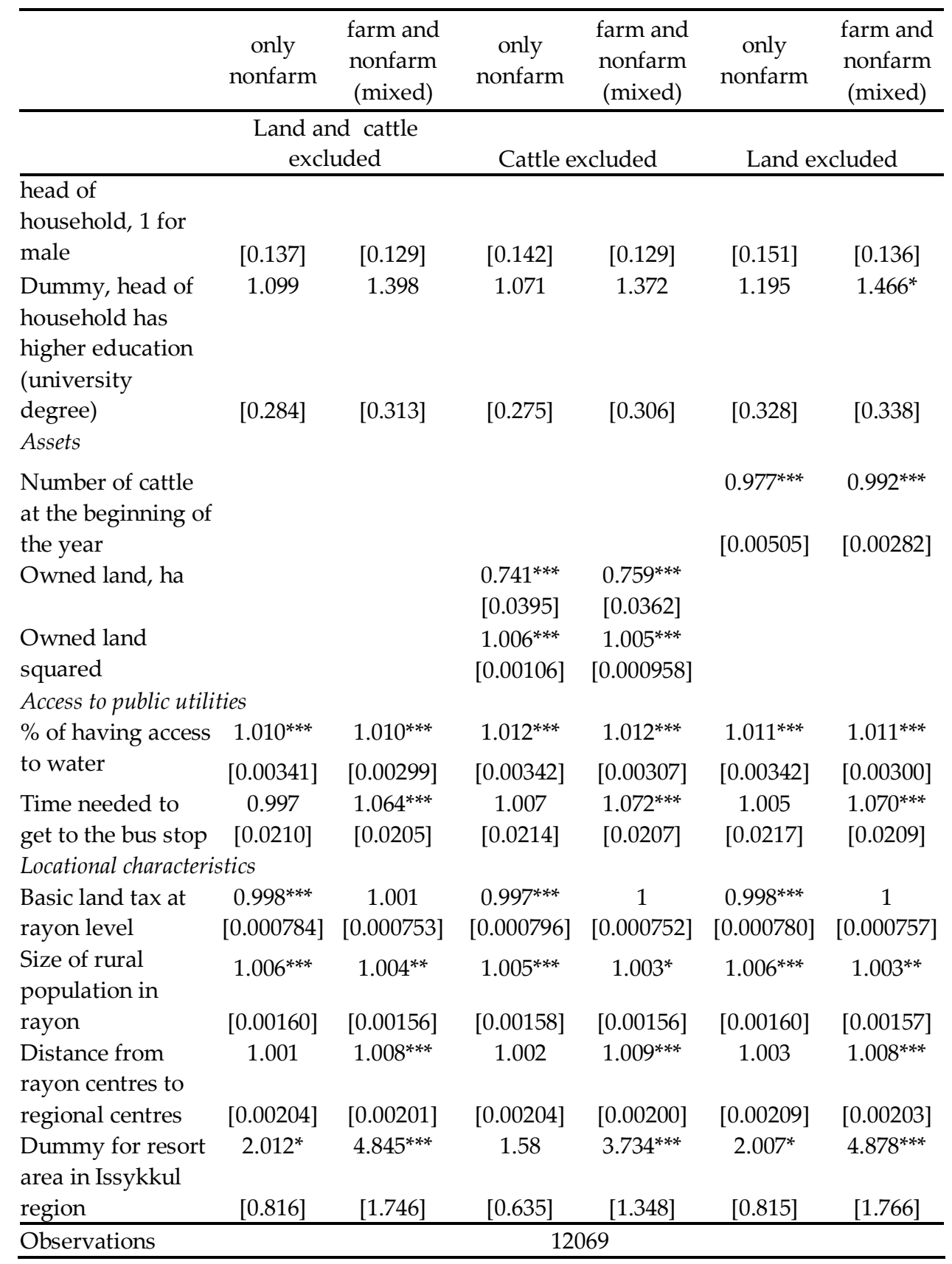

Source: NSC, authors' estimation.

Notes: The base category is pure farming. ${ }^{* *} \mathrm{p}<0.01,{ }^{* *} \mathrm{p}<0.05,{ }^{*} \mathrm{p}<0.1$ Intercepts, regional and quarterly dummies are not reported. Weighted, robust, and clustered at the household level standard errors are in parentheses. 
Table A4.6. Truncated regression for logarithm of rural nonfarm selfemployment income without potentially endogenous variables, 2005 year

\begin{tabular}{|c|c|c|c|c|}
\hline & \multicolumn{4}{|c|}{ Logarithm of self-employment income } \\
\hline & $\begin{array}{c}\text { Full } \\
\text { specificati } \\
\text { on } \\
\end{array}$ & $\begin{array}{l}\text { Land and } \\
\text { cattle } \\
\text { excluded }\end{array}$ & $\begin{array}{c}\text { Cattle } \\
\text { excluded }\end{array}$ & $\begin{array}{c}\text { Land } \\
\text { excluded }\end{array}$ \\
\hline \multicolumn{5}{|l|}{ Individual characteristics } \\
\hline \multirow[t]{2}{*}{ Age } & -0.00429 & -0.00423 & -0.00359 & -0.00518 \\
\hline & {$[0.0244]$} & {$[0.0245]$} & {$[0.0244]$} & {$[0.0244]$} \\
\hline \multirow[t]{2}{*}{ Age squared } & 4.65E-05 & 3.25E-05 & 3.66E-05 & 4.72E-05 \\
\hline & {$[0.000311]$} & {$[0.000312]$} & {$[0.000312]$} & {$[0.000311]$} \\
\hline \multirow[t]{2}{*}{ Dummy, 1 for male } & $0.172^{* *}$ & $0.179^{* *}$ & $0.172^{* *}$ & $0.179^{* *}$ \\
\hline & {$[0.0757]$} & {$[0.0761]$} & {$[0.0757]$} & {$[0.0760]$} \\
\hline \multirow[t]{2}{*}{ Dummy, 1 for married } & 0.0975 & 0.0698 & 0.0904 & 0.0818 \\
\hline & [0.0975] & [0.0996] & [0.0982] & [0.0991] \\
\hline \multirow[t]{2}{*}{ Dummy, head } & $0.162^{*}$ & $0.161^{*}$ & $0.160^{*}$ & $0.165^{*}$ \\
\hline & [0.0911] & {$[0.0921]$} & {$[0.0910]$} & [0.0921] \\
\hline \multirow[t]{2}{*}{ Dummy, Kyrgyz } & $-0.178^{* *}$ & $-0.139 *$ & $-0.156^{*}$ & $-0.168^{*}$ \\
\hline & {$[0.0887]$} & {$[0.0822]$} & {$[0.0808]$} & [0.0899] \\
\hline \multirow{2}{*}{ Dummy, higher education } & $0.594^{* * *}$ & $0.603^{* * *}$ & $0.596^{* * *}$ & $0.600^{* * *}$ \\
\hline & [0.191] & [0.194] & [0.192] & [0.193] \\
\hline \multirow{2}{*}{$\begin{array}{l}\text { Dummy, vocational } \\
\text { education }\end{array}$} & $0.275^{*}$ & $0.281^{*}$ & $0.269^{*}$ & $0.287^{*}$ \\
\hline & [0.152] & {$[0.156]$} & {$[0.156]$} & {$[0.151]$} \\
\hline \multirow{2}{*}{$\begin{array}{l}\text { Dummy, secondary } \\
\text { education }\end{array}$} & 0.181 & 0.189 & 0.173 & 0.198 \\
\hline & {$[0.146]$} & {$[0.148]$} & [0.149] & {$[0.145]$} \\
\hline \multicolumn{5}{|l|}{ Household characteristics } \\
\hline \multirow[t]{2}{*}{ Size of the household } & 0.0281 & 0.0306 & 0.0292 & 0.0288 \\
\hline & [0.0229] & {$[0.0236]$} & {$[0.0230]$} & [0.0235] \\
\hline \multirow[t]{2}{*}{ Dependence ration } & 0.0635 & 0.102 & 0.0635 & 0.0959 \\
\hline & {$[0.171]$} & {$[0.170]$} & [0.169] & {$[0.172]$} \\
\hline \multirow{2}{*}{$\begin{array}{l}\text { Age of the head of } \\
\text { household }\end{array}$} & 0.000449 & 0.00152 & 0.000532 & 0.00131 \\
\hline & {$[0.00406]$} & {$[0.00418]$} & {$[0.00409]$} & {$[0.00412]$} \\
\hline \multirow{2}{*}{$\begin{array}{l}\text { Gender of the head of } \\
\text { household, } 1 \text { for male }\end{array}$} & 0.0239 & 0.0517 & 0.0346 & 0.0359 \\
\hline & {$[0.0955]$} & {$[0.0956]$} & [0.0949] & [0.0966] \\
\hline \multirow{2}{*}{$\begin{array}{l}\text { Dummy, head of household } \\
\text { has higher education }\end{array}$} & 0.0608 & 0.112 & 0.039 & 0.13 \\
\hline & [0.131] & {$[0.128]$} & [0.126] & {$[0.131]$} \\
\hline \multicolumn{5}{|l|}{ Assets } \\
\hline \multirow{2}{*}{$\begin{array}{l}\text { Number of cattle by the } \\
\text { beginning of the year }\end{array}$} & $0.00656^{* *}$ & & $0.00730^{* * *}$ & \\
\hline & {$[0.00272]$} & & {$[0.00267]$} & \\
\hline \multirow[t]{2}{*}{ Owned land, ha } & 0.0752 & & & 0.0912 \\
\hline & {$[0.0771]$} & & & {$[0.0771]$} \\
\hline \multirow[t]{2}{*}{ Owned land squared } & -0.00693 & & & -0.00807 \\
\hline & [0.0109] & & & {$[0.0106]$} \\
\hline
\end{tabular}

Access to public utilities 


\begin{tabular}{lcccc}
\hline \multicolumn{4}{c}{ Logarithm of self-employment income } \\
\hline & $\begin{array}{c}\text { Full } \\
\text { specificati } \\
\text { on }\end{array}$ & $\begin{array}{c}\text { Land and } \\
\text { cattle } \\
\text { excluded }\end{array}$ & $\begin{array}{c}\text { Cattle } \\
\text { excluded }\end{array}$ & $\begin{array}{c}\text { Land } \\
\text { excluded }\end{array}$ \\
\hline \% of having access to water & $-0.00271^{*}$ & $-0.00264^{*}$ & $-0.00270^{*}$ & $-0.00265^{*}$ \\
& {$[0.00161]$} & {$[0.00154]$} & {$[0.00157]$} & {$[0.00158]$} \\
Time needed to get to the & -0.0194 & -0.0171 & -0.0206 & -0.0161 \\
bus stop & {$[0.0151]$} & {$[0.0151]$} & {$[0.0153]$} & {$[0.0148]$} \\
Locational characteristics & & & & \\
Basic land tax at rayon level & 0.00018 & $7.83 \mathrm{E}-05$ & 0.000178 & $9.74 \mathrm{E}-05$ \\
& {$[0.000381]$} & {$[0.000383]$} & {$[0.000377]$} & {$[0.000389]$} \\
Size of rural population in & -0.000331 & -0.000548 & -0.000371 & -0.000474 \\
rayon & {$[0.000764]$} & {$[0.000736]$} & {$[0.000754]$} & {$[0.000748]$} \\
Distance from rayon centres & $-0.00506^{* * *}$ & $-0.00457^{* * *}$ & $-0.00498^{* * *}$ & $-0.00473^{* * *}$ \\
to regional centres & {$[0.00106]$} & {$[0.00107]$} & {$[0.00106]$} & {$[0.00109]$} \\
Dummy for resort area in & $0.429^{* * *}$ & $0.367^{* *}$ & $0.358^{* *}$ & $0.454^{* * *}$ \\
Issykkul region & {$[0.154]$} & {$[0.174]$} & {$[0.151]$} & {$[0.169]$} \\
\hline Observations & \multicolumn{4}{c}{940} \\
\hline
\end{tabular}

Source: NSC, authors' estimation

Note: ${ }^{* *} \mathrm{p}<0.01,{ }^{* *} \mathrm{p}<0.05,{ }^{*} \mathrm{p}<0.1$ Regional and quarterly dummies are not reported.

Weighted, robust, and clustered at the household level standard errors are in parentheses.

Table A4.7. Results from the multivariate probit model for primary participation in rural nonfarm activities, 2005

\begin{tabular}{cccc}
$\begin{array}{c}\text { Self- } \\
\text { employment }\end{array}$ & $\begin{array}{c}\text { Employment } \\
\text { by } \\
\text { individuals }\end{array}$ & $\begin{array}{c}\text { Employment } \\
\text { in private } \\
\text { organisations }\end{array}$ & $\begin{array}{c}\text { Employment } \\
\text { in public } \\
\text { organisation }\end{array}$ \\
\hline
\end{tabular}

\begin{tabular}{lcccc}
\hline Individual characteristics & & & & \\
Age & $0.102^{* * *}$ & $0.0498^{* *}$ & $0.0629^{* * *}$ & $0.0567^{* * *}$ \\
& {$[0.0211]$} & {$[0.0222]$} & {$[0.0224]$} & {$[0.0207]$} \\
Age squared & $-0.00129^{* * *}$ & $-0.000852^{* * *}$ & $-0.000664^{* *}$ & $-0.000583^{* *}$ \\
Dummy, 1 for male & {$[0.000281]$} & {$[0.000295]$} & {$[0.000276]$} & {$[0.000265]$} \\
& 0.11 & $0.349^{* * *}$ & $0.352^{* * *}$ & $-0.557^{* * *}$ \\
Dummy, 1 for married & {$[0.0755]$} & {$[0.0881]$} & {$[0.0872]$} & {$[0.0782]$} \\
& 0.0186 & $-0.270^{* * *}$ & -0.109 & $-0.186^{*}$ \\
Dummy, head & {$[0.106]$} & {$[0.102]$} & {$[0.113]$} & {$[0.106]$} \\
& 0.0371 & 0.0378 & 0.0763 & 0.00262 \\
Dummy, Kyrgyz & {$[0.102]$} & {$[0.112]$} & {$[0.105]$} & {$[0.0998]$} \\
& $-0.318^{* * *}$ & $-0.297^{* * *}$ & -0.154 & $0.198^{*}$ \\
Dummy, higher education & {$[0.109]$} & {$[0.101]$} & {$[0.106]$} & {$[0.107]$} \\
& -0.197 & -0.304 & $1.082^{* * *}$ & $1.764^{* * *}$ \\
Dummy, vocational & {$[0.208]$} & {$[0.225]$} & {$[0.184]$} & {$[0.186]$} \\
education & $0.360^{* *}$ & 0.0604 & $0.657^{* * *}$ & $0.821^{* * *}$ \\
& {$[0.141]$} & {$[0.137]$} & {$[0.156]$} & {$[0.176]$}
\end{tabular}




\begin{tabular}{|c|c|c|c|c|}
\hline & $\begin{array}{c}\text { Self- } \\
\text { employment }\end{array}$ & $\begin{array}{l}\text { Employment } \\
\text { by } \\
\text { individuals }\end{array}$ & $\begin{array}{l}\text { Employment } \\
\text { in private } \\
\text { organisations } \\
\end{array}$ & $\begin{array}{l}\text { Employment } \\
\text { in public } \\
\text { organisation }\end{array}$ \\
\hline $\begin{array}{l}\text { Dummy, secondary } \\
\text { education }\end{array}$ & $\begin{array}{l}0.273^{* *} \\
{[0.129]}\end{array}$ & $\begin{array}{l}0.0323 \\
{[0.123]}\end{array}$ & $\begin{array}{l}0.402^{* * *} \\
{[0.152]}\end{array}$ & $\begin{array}{l}-0.0213 \\
{[0.171]}\end{array}$ \\
\hline \multicolumn{5}{|l|}{ Household characteristics } \\
\hline Size of the household & $\begin{array}{l}0.00366 \\
{[0.0241]}\end{array}$ & $\begin{array}{l}0.00507 \\
{[0.0244]}\end{array}$ & $\begin{array}{l}0.00722 \\
{[0.0243]}\end{array}$ & $\begin{array}{c}0.0112 \\
{[0.0246]}\end{array}$ \\
\hline Dependence ration & $\begin{array}{l}-0.422^{* *} \\
{[0.207]}\end{array}$ & $\begin{array}{l}-0.0515 \\
{[0.206]}\end{array}$ & $\begin{array}{l}-0.440^{* *} \\
{[0.206]}\end{array}$ & $\begin{array}{c}-0.284 \\
{[0.175]}\end{array}$ \\
\hline $\begin{array}{l}\text { Age of the head of } \\
\text { household }\end{array}$ & $\begin{array}{c}-0.0031 \\
{[0.00402]}\end{array}$ & $\begin{array}{c}-0.00093 \\
{[0.00400]}\end{array}$ & $\begin{array}{c}0.00463 \\
{[0.00367]}\end{array}$ & $\begin{array}{c}-0.0049 \\
{[0.00379]}\end{array}$ \\
\hline $\begin{array}{l}\text { Gender of the head of } \\
\text { household, } 1 \text { for male }\end{array}$ & $\begin{array}{c}-0.141 \\
{[0.108]}\end{array}$ & $\begin{array}{l}0.0355 \\
{[0.118]}\end{array}$ & $\begin{array}{c}-0.00491 \\
{[0.113]}\end{array}$ & $\begin{array}{l}0.0646 \\
{[0.109]}\end{array}$ \\
\hline $\begin{array}{l}\text { Dummy head of household } \\
\text { has higher education } \\
\text { Assets }\end{array}$ & $\begin{array}{c}0.185 \\
{[0.179]}\end{array}$ & $\begin{array}{c}-0.237 \\
{[0.196]}\end{array}$ & $\begin{array}{c}0.042 \\
{[0.150]}\end{array}$ & $\begin{array}{c}0.0772 \\
{[0.110]}\end{array}$ \\
\hline $\begin{array}{l}\text { Number of cattle by the } \\
\text { beginning of the year }\end{array}$ & $\begin{array}{c}-0.00374 \\
{[0.00258]}\end{array}$ & $\begin{array}{l}-0.0233^{* * *} \\
{[0.00549]}\end{array}$ & $\begin{array}{l}-0.00169 \\
{[0.00220]}\end{array}$ & $\begin{array}{l}-0.00198 \\
{[0.00136]}\end{array}$ \\
\hline Owned land, ha & $\begin{array}{l}-0.146^{* * *} \\
{[0.0543]}\end{array}$ & $\begin{array}{l}-0.0943^{* *} \\
{[0.0397]}\end{array}$ & $\begin{array}{l}-0.0839^{* *} \\
{[0.0335]}\end{array}$ & $\begin{array}{l}-0.0136 \\
{[0.0246]}\end{array}$ \\
\hline Owned land squared & $\begin{array}{l}0.00287^{* * *} \\
{[0.00103]}\end{array}$ & $\begin{array}{c}0.00160^{*} \\
{[0.000903]}\end{array}$ & $\begin{array}{c}0.00150^{* *} \\
{[0.000627]}\end{array}$ & $\begin{array}{c}0.000223 \\
{[0.000523]}\end{array}$ \\
\hline \multicolumn{5}{|l|}{ Access to public utilities } \\
\hline$\%$ of having access to water & $\begin{array}{l}0.00428^{*} \\
{[0.00248]}\end{array}$ & $\begin{array}{l}0.00537^{* *} \\
{[0.00235]}\end{array}$ & $\begin{array}{c}0.00359 \\
{[0.00223]}\end{array}$ & $\begin{array}{l}0.00543^{* * *} \\
{[0.00172]}\end{array}$ \\
\hline $\begin{array}{l}\text { Time needed to get to the } \\
\text { bus stop } \\
\text { Locational characteristics }\end{array}$ & $\begin{array}{l}0.00364 \\
{[0.0128]}\end{array}$ & $\begin{array}{c}-0.02 \\
{[0.0156]}\end{array}$ & $\begin{array}{l}-0.0284^{*} \\
{[0.0170]}\end{array}$ & $\begin{array}{c}0.0406^{* * *} \\
{[0.0111]}\end{array}$ \\
\hline $\begin{array}{l}\text { Basic land tax at rayon } \\
\text { level, }\end{array}$ & $\begin{array}{l}-0.00122^{* *} \\
{[0.000497]}\end{array}$ & $\begin{array}{l}-1.43 \mathrm{E}-05 \\
{[0.000513]}\end{array}$ & $\begin{array}{c}-0.00033 \\
{[0.000587]}\end{array}$ & $\begin{array}{c}-0.00068 \\
{[0.000467]}\end{array}$ \\
\hline $\begin{array}{l}\text { Size of rural population in } \\
\text { rayon }\end{array}$ & $\begin{array}{l}0.00236^{* *} \\
{[0.000996]}\end{array}$ & $\begin{array}{l}0.00221^{* *} \\
{[0.00110]}\end{array}$ & $\begin{array}{l}-0.00049 \\
{[0.00116]}\end{array}$ & $\begin{array}{c}-0.00028 \\
{[0.000988]}\end{array}$ \\
\hline $\begin{array}{l}\text { Distance from rayon } \\
\text { centres to regional centres }\end{array}$ & $\begin{array}{l}0.00245^{*} \\
{[0.00148]}\end{array}$ & $\begin{array}{l}0.00329^{* *} \\
{[0.00138]}\end{array}$ & $\begin{array}{r}-0.00064 \\
{[0.00132]}\end{array}$ & $\begin{array}{l}0.00264^{* *} \\
{[0.00107]}\end{array}$ \\
\hline $\begin{array}{l}\text { Dummy for resort area in } \\
\text { Issykkul region }\end{array}$ & $\begin{array}{l}0.556^{*} \\
{[0.330]}\end{array}$ & $\begin{array}{l}0.0534 \\
{[0.212]}\end{array}$ & $\begin{array}{l}1.244^{* * *} \\
{[0.222]}\end{array}$ & $\begin{array}{c}-0.910^{* * *} \\
{[0.258]}\end{array}$ \\
\hline Observations & 12069 & 12069 & 12069 & 12069 \\
\hline $\begin{array}{l}\text { Likelihood ratio test of } \\
\text { rho } 21=\operatorname{rho} 31=\operatorname{rho} 41= \\
\text { rho32 }=\operatorname{rho} 42=\operatorname{rho} 43=0\end{array}$ & $\operatorname{chi} 2(6$ & $1 \mathrm{e}+06$ & Prob $>c$ & 0.0000 \\
\hline
\end{tabular}

Source: NSC, authors' estimation

Note: ${ }^{* *} \mathrm{p}<0.01,{ }^{* *} \mathrm{p}<0.05,{ }^{*} \mathrm{p}<0.1$ Regional and quarterly dummies are not reported. Weighted, robust, and clustered at the household level standard errors are in parentheses. 
Table A4.8. Results from Hausman tests of IIA assumption, 2005 (N=12069)

\begin{tabular}{llccc}
\hline Omitted & chi2 & df & P $>$ chi2 & evidence \\
\hline only nonfarm & -185.024 & 32 & & for Ho \\
farm and nonfarm & -13.993 & 31 & & for Ho \\
\hline
\end{tabular}

Table A4.9. Results from Small-Hsiao tests of IIA assumption, 2005 (N=12069)

\begin{tabular}{lllllll}
\hline Omitted & $\operatorname{lnL}($ full $)$ & $\ln L($ omit $)$ & chi2 & df & P $>$ chi2 & evidence \\
\hline $\begin{array}{l}\text { only nonfarm } \\
\text { farm and }\end{array}$ & -1796.532 & -1777.422 & 38.22 & 33 & 0.244 & for Ho \\
nonfarm & -2027.352 & -2004.149 & 46.407 & 33 & 0.061 & for Ho \\
\hline
\end{tabular}

Table A4.10. Results from Hausman tests of IIA assumption, $2006(\mathrm{~N}=13408)$

\begin{tabular}{llccc}
\hline Omitted & chi2 & df & P $>$ chi2 & evidence \\
\hline only nonfarm & -202.453 & 32 & & for Ho \\
farm and nonfarm & -419.653 & 32 & & for Ho \\
\hline
\end{tabular}

Table A4.11. Results from Small-Hsiao tests of IIA assumption, 2006 (N=13408)

\begin{tabular}{lcccccc}
\hline Omitted & $\operatorname{lnL}($ full) & $\operatorname{lnL}$ (omit) & chi2 & df & P>chi2 & evidence \\
\hline only nonfarm & -1890.565 & -1872.265 & 36.6 & 33 & 0.305 & for Ho \\
farm and nonfarm & -2505.47 & -2489.48 & 31.979 & 33 & 0.518 & for Ho \\
\hline
\end{tabular}




\section{THE CHOICE BETWEEN INTERNATIONAL MIGRATION AND LOCAL RURAL ACTIVITIES IN THE KYRGYZ REPUBLIC ${ }^{32}$}

This chapter uses a unique representative household budget survey from the Asian Development Bank to analyse separately the determinants of permanent and seasonal migration in rural areas of the Kyrgyz Republic and compare them with determinants of local income generating activities. We have found that both permanent migration and local wage nonfarm employment substitute agricultural activities and compete for the most educated rural individuals. The difference is that the permanent migration option is unattainable for individuals from poor households with small land holdings. They tend to engage in local nonfarm activities, while those who are educated and have resources to finance the cost of migration choose to leave the country permanently. Finally, in contrast to permanent migration, seasonal migration does not require possession neither of higher nor of vocational education which can make it potentially less harmful for local development in terms of brain drain.

32 This chapter is based on an article co-authored with Marrit van den Berg, under review at Central Asian Survey. 


\section{$5.1 \quad$ INTRODUCTION}

International migration is often viewed as an important alternative to economic difficulties at home. A poor agricultural base, risky and seasonal agriculture, and numerous market imperfections stimulate labour migration from developing countries. Migration is a selective process, and migrants are distinct from those who stay at home. Initially migrants are often better educated and originate from the middle range of the income distribution (Mckenzie \& Rapoport, 2007). This implies that migration may not be an easily accessible option for those in need and can take away the most productive workers from local agricultural and nonfarm activities. Identifying motivations for and barriers to international migration is crucial for understanding which rural individuals and households bear the costs or potential benefits from this process and which policies should be implemented to strengthen its developmental impact (Taylor \& Martin, 2001; Mora \& Taylor, 2005).

After 2000, the poorest Central Asian countries have become prominent suppliers of labour migrants to the neighbouring Russian Federation and the largest recipients of remittances among the Former Soviet Union countries. Predominantly rural and poor Kyrgyzstan is an interesting case to study. Policy makers and the donor community increasingly acknowledge that the development of small-scale agriculture alone is not sufficient to achieve sustainable poverty reduction. International migration and the local nonfarm sector may help to absorb surplus labour, but it is important to find out whether households in need are able to replace or complement agricultural activities by migration or nonfarm activities. Moreover, participation in international migration and in local nonfarm activities may have similar requirements with regards to initial assets and human capital and may therefore compete with and constrain each other. If, for example, higher education is required to participate in both local nonfarm activities and international migration, the brain drain effect may weaken the local capacity to develop nonfarm activities. Yet to the best of our knowledge, there is complete lack of quantitative analysis of the determinants of migration in Kyrgyzstan. The only existing studies on migration and remittances are descriptive and qualitative (ADB, 2008a; Schmidt \& Sagynbekova, 2008; Mogilevsky \& Atamanov, 2009; OECD et al., 2009).

Studying migration processes in the Kyrgyz Republic is especially interesting because seasonal and permanent migration are about equally important. ${ }^{33}$ Seasonal migration is a poorly understood and neglected phenomenon in the migration literature that has recently gained a growing interest (Görlich \&

\footnotetext{
${ }^{33}$ By permanent migration we mean non-seasonal long-term migration which does not involve repeated moves during particular seasons and can result in permanent stay of migrants abroad.
} 
Trebesch, 2008). The interest is stimulated by the debate about whether seasonal migration is preferable to permanent migration due to its potential to mitigate the cost of separation, to lower brain drain effects, and to favour the return of human capital and remittances (Newland, 2009; Hugo, 2009). Obviously, the benefits of seasonal and permanent migration will depend on their specific drivers and on who self-selects for each particular type of migration. Still, comparisons of the determinants of permanent and seasonal migration have been rarely done in empirical studies (exceptions are Mendola, 2004; Görlich \& Trebesch, 2006; Joarder \& Hasanuzzaman, 2008; Vadean \& Piracha, 2009; Pinger, 2010).

Therefore, our study aims to analyse the factors which determine participation in both seasonal and permanent international migration in rural areas of the Kyrgyz Republic, and how these factors differ from the determinants of participation in local farm and nonfarm activities. The analysis is based on a unique representative household budget survey conducted by the Asian Development Bank in 2007.

It is the first study to analyse determinants of migration in Kyrgyzstan and one of very few ones to analyse participation in permanent and seasonal migration separately. The study incorporates both migration decisions and local income generating activities in a single empirical model. New empirical evidence of these processes in post-Soviet Central Asian context may enrich migration theories, contribute to the ongoing debate about seasonal and permanent migration, and inform policy makers about the role of migration among other income generating activities.

The chapter is organised as follows. It starts with a discussion of the theoretical framework. Then background information and data are described. Next section covers econometric specification. Subsequently, empirical results are presented and discussed. The last section concludes.

\subsection{THEORETICAL FRAMEWORK}

In neoclassical economics individual rational actors choose to migrate based on the expected net benefits. An individual will migrate if the expected returns are higher than the expected costs. Human capital characteristics influence both wages and probabilities of obtaining a job, implying that migration is a selective process and that often the young, better educated and less-risk averse individuals are overrepresented among migrants (Martin \& Taylor, 2001).

The New Economics of Labour Migration (NELM) has challenged the assumptions and conclusions of neoclassical migration theory (Stark \& Bloom, 1985). Namely, the NELM considers the migration decision as taking place in a wider social context, such as the household/family, rather than as a purely individual act. According to this theory, migration is mainly driven by market imperfections. The family does not only maximise joint income, but also minimises 
risks and loosens constraints created by different types of market failures. In addition, since the impact of income on utility is not homogeneous in different socioeconomic groups, a household's income position relative to its reference group (for instance, in the same village) can also stimulate migration (Stark \& Bloom, 1985; Massey et al., 1993). The NELM expanded the range of potential determinants of migration by adding the human capital of household members, household assets and different kinds of market imperfections to individual characteristics of migrants.

Besides neoclassical economics and the NELM, network migration theory identifies another important determinant of migration. Namely, it stresses the importance of current and past migrants that form networks fulfilling the functions of social capital. Early migrants provide potential migrants with information about labour market conditions, initial accommodation and other helpful actions which can significantly reduce costs of migration especially in destinations involving high costs, high risks and scarcity of information (Martin \& Taylor, 2001). Migration network theory predicts that previous migration experience, connection to someone living abroad and living in areas with larger number of migrants are expected to increase the propensity to migrate (Massey, 1990; Massey et al., 1993). ${ }^{34}$

Finally, livelihood theory considers migration as one of the potential livelihood strategies along with agricultural intensification/extensification and livelihood diversification. Given a particular context, shaped by policy settings, history, politics, agro-ecology and socio-economic conditions a household may choose between these three strategies or combinations of them based on their available resources. The poor are supposedly the most willing to employ the migration strategy, but at the same time they are the most constrained to do so due to lack of access to resources and institutions (Scoones, 1998; De Haan, 1999). Important factors shaping the capacity to migrate are social capital (networks, contacts), cultural and identity capital (ethnicity, religion, gender), human capital (education, household structure), geographical capital (natural environments, remoteness from markets) and political capital (Kothari, 2002: 12).

The livelihood approach and the migration theories help to identify the potential determinants of migration, which may overlap with the determinants of local income generating activities. Since in this work our focus is on rural areas, land ownership is one of the crucial assets determining the incentives and capacity to undertake nonfarm activities. Studies of nonfarm activities often mention participation in nonfarm activities as a natural response of landless or those with lack of land who cannot generate enough agricultural income. Similarly, lack of

\footnotetext{
${ }^{34}$ Network migration theory is closely related to the concept of transnationalism which considers migrants to be simultaneously engaged in both home country and countries they lived or are living. Therefore, both locations should be incorporated into one research framework (Mazzucato, 2009).
} 
land may act as an incentive to migrate. However, actual participation in local nonfarm activities and migration is determined not only by incentives but also by the capacity of rural residents to overcome potential entry barriers. If participation requires substantial costs those with small land holdings can be excluded. This makes the impact of land an empirical question.

Another important variable playing a significant role for participation in income generating activities both at home and abroad is education. Numerous studies of the determinants of nonfarm activities identify education as one of the crucial factors, especially regarding access to wage employment. As we also showed that migration may bring higher benefits for those with better education, nonfarming and international migration can compete with each other for the most productive members of the household. As a result, the brain drain effect associated with migration may negatively affect local nonfarm production capacity.

Identification of the determinants of migration should take into account that it is not necessarily a homogeneous process and may include permanent as well as temporary mobility. Most neoclassical theories and the NELM do not distinguish between these two (Martin \& Taylor, 2001). Moreover, there are very few empirical studies analysing seasonal migration (Görlich \& Trebesch, 2008). At the same time, circular ${ }^{35}$ migration has long history mainly appearing in the anthropological and demographic literature, but due to lack of data it has not been researched extensively in quantitative studies (Hugo, 2009). Only in 2005 did the Global Commission for Migration state that the old paradigm of permanent migration was being replaced by permanent and circular migration. The interest in circular migration is triggered by assumptions that it is better able to address development challenges since circular migrants are more committed to the home community, are supposed to remit a larger part of their income, return home regularly and bring new skills. Finally, a liberalisation of the regime for temporary migration is easier to sell to the electorates of the host countries (Abella, 2006). ${ }^{36}$

Stark and Fan (2007) developed a formal model of the determinants of the return decision for migrants. In their model, the utility of a breadwinner migrant is a function of family consumption minus the cost of separation from the family. Family consumption equals the breadwinner's real earnings at home and abroad.

35 We use the terms seasonal and circular interchangeably in this paper, but circular migration is a much wider concept and includes temporary migration with temporary return (seasonal), permanent migration with permanent return, permanent migration with temporary return and temporary migration with permanent return (see discussion in Erzan, 2008).

${ }^{36}$ Benefits from circular migration are mainly discussed in the light of creating managed circular migration systems. A more or less effective system of circular migration exists in the OECD and mainly covers highly skilled workers (Hugo, 2009). In our particular case, seasonal migration is spontaneous as a result of migrants' decisions. 
The first order conditions suggest that the cost of living and income differentials and the cost of separation determine the migrant's decision to migrate alone without family and make him/her return.

The role of education in permanent and seasonal migration brings an interesting contribution to human capital theory and the brain drain/gain discussion (Martin \& Taylor, 2001; Dustmann \& Weiss, 2007; Faini, 2007). Human capital theory claims that migration selects the better educated individuals, which imposes costs on home country tax payers who partially finance the human capital of future migrants. However, education seems to be more important for permanent migrants, who tend to be abroad longer and manage to get formal long-term employment, than for seasonal migrants. Therefore, better educated individuals are expected to self-select into permanent migration which can lead to brain drain effect in contrast to seasonal migration which has less negative effects (Newland, 2009). This could also make permanent migration and local nonfarm activities compete with each other to attract the most educated workers.

\subsection{BACKGROUND AND DATA}

Since 2002-2003 there has been a lot of interest in migration and remittances in the Kyrgyz Republic. This is related to a sharp increase in the number of migrants to the Russian Federation and Kazakhstan, driven by the robust economic growth in these countries, their large demand for labour and high expected benefits due to considerable difference in wages at home and abroad. In addition, improvement and stabilisation of the financial sector in Kyrgyzstan coupled with ubiquitous distribution of Money Transfer Companies made remittances visible (ABD, 2008b). In spite of these facts, the analysis of migration and remittances was highly constrained by the lack of data. For instance, the estimates of the numbers of migrants varied between 200.000 and 500.000 in 2005-2007. The only representative study of labour migration and remittances, used in this work and conducted by the Asian Development Bank, showed 251,000 migrants in 2006 with an aggregate inflow of cash remittances in the range of 214.1-276.3 mln. USD (ADB, 2008b). Most migrants came from rural areas and about half of them were seasonal migrants who returned home regularly every year.

To the best of our knowledge, there are no quantitative studies of the determinants of migration in the Kyrgyz Republic in general and seasonal and permanent migration in particular. However, several studies discuss the main reasons behind international migration qualitatively (Schmidt \& Sagynbekova, 2008; ADB, 2008ac; OECD et al., 2009). Like nonfarm activities, international labour migration is considered to be driven by the combination of "push" and "pull" factors. Poor economic conditions, demographic pressure, and unemployment at home are the most important among "push" factors. Higher wages and demand for labour in oil rich the Russian Federation and Kazakhstan constitute "pull" 
factors. The migrants fill niches in the labour markets of Kazakhstan and the Russian Federation (construction, trade, street cleaning) that their indigenous citizens do not find as attractive as other employment options (OECD et al., 2009). Besides for purely economic reasons, migrants go to Kazakhstan and the Russian Federation because of cultural kinship and common languages. Most migrants speak Russian and the Kazakh language is very similar to Kyrgyz (ADB, 2008b). Finally, the desire to leave rural areas to improve the quality of life, to gain independence from parents, and the "following the majority" effect are mentioned as determinants of migration (OECD et al., 2009). Unfortunately, none of these works analyses quantitatively how individual, household and local factors shape migration decisions. The current study aims to contribute to closing this gap.

The representative database used in this research was collected in the framework of the regional study on remittances and poverty organised and financed by the Asian Development Bank. The selection of households was conducted using stratified two-stage random sampling. The target sample was 4200 households, but the actual number was 3997 households divided into three strata, the capital, other urban areas, and rural areas, in proportion to the share of these categories in the total number of households in the population. This procedure formed three representative samples and also allows for estimating variables at the community level.

The survey was conducted in early 2007. For the purpose of our study we have chosen the rural subsample consisting of 2485 households and 7686 individuals of working age between 15 and 65 years, after omitting observations with missing data and outliers. 430 households $(17.3 \%$ of total sample of rural households) had at least one migrant household member abroad in 2006. Of these 430 households, $72.1 \%$ had one migrant, $20.5 \%$ two migrants, $4.9 \%$ three migrants, $2.3 \%$ four migrants, and $0,2 \%$ had five migrants in 2006. 217 households had at least one seasonal migrant and 213 households had at least one permanent migrant. Only 10 households had both permanent and seasonal migrants. In total, there were 592 migrants from rural areas in the sample. Among them 292 were seasonal and 300 were permanent migrants. There is no clear indication in the questionnaire on how to distinguish between seasonal and permanent migrants, except for a direct question whether a person is a seasonal migrant or not. Most probably the respondents interpreted this question as whether a person went abroad for predetermined period of less than one year and returned home regularly.

The employment pattern among rural individuals in 2006 was diverse. $23.4 \%$ were doing unpaid family work (mainly housework and farm work), $21.6 \%$ were employed in agricultural sector, $21.5 \%$ were employed in nonfarm activities ${ }^{37}$

${ }_{37}$ Unfortunately, there is no distinction between farm and nonfarm wage in the data. However, we checked representative household budget surveys from the National 
(5.2\% in self-employment, $7.1 \%$ in private wage employment, and $9.2 \%$ in public wage employment), $14.7 \%$ were full time students, $6.1 \%$ were unemployed, about $7.7 \%$ were seasonal and permanent migrants, and finally $5 \%$ were pensioners.

Table 5.1 presents general information on individual characteristics across occupations and tests for the significance of differences of means for migrants versus non-migrants and seasonal versus permanent migrants. There are substantial differences between individuals in the different categories.

There were more non-married males among migrants and they were younger and better educated than non-migrants. Permanent migrants were better educated than seasonal migrants and they were less likely to be heads of household. $57 \%$ of seasonal migrants were employed in construction in comparison to $43 \%$ of permanent migrants.

Human capital characteristics also differ across local occupations. There were more women among those doing unpaid family work and among those who undertook public nonfarm employment. Participation in the public sector required a high level of education, and the average educational level of public sector workers even exceeded those of permanent migrants. In order to get detailed information on education we estimated shares of different education categories in each occupational choice (figure 5.1). Half of the public employees had received higher education. Permanent migrants had the second largest share of people with higher education: $15.3 \%$. People with vocational education were relatively frequently engaged in nonfarm activities and permanent migration. Interestingly, the share of people with vocational education was higher among the unemployed than among those working in agriculture. The educational composition of seasonal migrants and those employed in agriculture was very similar.

Statistical Committee used in chapters 3 and 4 . Wage employment in agriculture accounted on average only for $2 \%$ of total rural employment in 2005 . Therefore, in this study we consider all wage employment as nonfarm. 
Table 5.1. Individual characteristics across occupations and test for the equality of means for migrants/non-migrants and seasonal/permanent migrants, 2006

\begin{tabular}{|c|c|c|c|c|c|c|c|c|c|}
\hline & \multirow{2}{*}{\multicolumn{3}{|c|}{ Unpai }} & \multicolumn{3}{|c|}{ Nonfarm employment } & \multicolumn{3}{|c|}{ Migration } \\
\hline & & & & & Wage & Wage & & & \\
\hline & $\begin{array}{l}\text { Unemp } \\
\text { loyed }\end{array}$ & $\begin{array}{c}\mathrm{d} \\
\text { family } \\
\text { work }\end{array}$ & $\begin{array}{l}\text { Agricu } \\
\text { lture }\end{array}$ & $\begin{array}{l}\text { Self- } \\
\text { employ- } \\
\text { ment }\end{array}$ & $\begin{array}{l}\text { employm } \\
\text { ent in } \\
\text { private } \\
\text { sector } \\
\end{array}$ & $\begin{array}{l}\text { employ } \\
\text { ment in } \\
\text { public } \\
\text { sector }\end{array}$ & All a & $\begin{array}{c}\text { Seasonal } \\
\mathrm{b}\end{array}$ & $\begin{array}{c}\text { Permane } \\
n^{b}{ }^{b}\end{array}$ \\
\hline $\begin{array}{l}\text { Gender, } \\
\text { female }\end{array}$ & $52 \%$ & $71 \%$ & $35 \%$ & $28 \%$ & $30 \%$ & $58 \%$ & $25.3 \%^{* * *}$ & $25 \%$ & $26 \%$ \\
\hline Age & 29.3 & 34.6 & 35.9 & 36 & 33.7 & 39.8 & $30.1^{* * * *}$ & 30.2 & 30 \\
\hline & [10.8] & [11.3] & {$[11.7]$} & [10.8] & [10.8] & [11.0] & {$[9.3]$} & [9.2] & [9.4] \\
\hline Years of & 11 & 10.8 & 10.7 & 11.1 & $\begin{array}{l}11.1 \\
\end{array}$ & $\begin{array}{l}13.5 \\
12.21\end{array}$ & $11.3^{* * * *}$ & $\begin{array}{c}11.0^{* * *} \\
{[1.6]}\end{array}$ & $\begin{array}{c}11.5^{* * *} \\
{[2.0]}\end{array}$ \\
\hline $\begin{array}{l}\text { education } \\
\text { Head of } \\
\text { household, \% }\end{array}$ & $\begin{array}{l}{[1.6]} \\
15 \%\end{array}$ & $\begin{array}{l}{[1.6]} \\
17 \%\end{array}$ & $\begin{array}{l}{[1.5]} \\
39 \%\end{array}$ & $\begin{array}{l}{[2.0]} \\
45 \%\end{array}$ & $\begin{array}{l}{[1.7]} \\
41 \%\end{array}$ & $\begin{array}{l}{[2.2]} \\
37 \%\end{array}$ & $\begin{array}{c}{[1.9]} \\
19.9 \%^{* * * *}\end{array}$ & $\begin{array}{c}{[1.6]} \\
25.7 \%^{* * *}\end{array}$ & $\begin{array}{c}{[2.0]} \\
14.3 \%^{* * *}\end{array}$ \\
\hline $\begin{array}{l}\text { Married } \\
\text { (registered, } \\
\text { unregistered, } \\
\% \text { ) }\end{array}$ & $48 \%$ & $77 \%$ & $71 \%$ & $70 \%$ & $64 \%$ & $76 \%$ & $49.0 \%^{* * *}$ & $47.9 \%$ & $50.0 \%$ \\
\hline $\begin{array}{l}\text { Abroad } \\
\text { employment } \\
\text { in } \\
\text { construction, } \\
\%\end{array}$ & - & - & - & - & - & - & $49.40 \%$ & $57 \% * * *$ & $43 \% \%^{* * *}$ \\
\hline $\begin{array}{l}\text { Abroad } \\
\text { employment } \\
\text { in trade, \% }\end{array}$ & - & - & - & - & - & - & $31.90 \%$ & $30 \%$ & $34 \%$ \\
\hline $\begin{array}{l}\% \text { in total } \\
\text { sample }\end{array}$ & $6.0 \%$ & $23.4 \%$ & $21.7 \%$ & $5.2 \%$ & $7.1 \%$ & $9.2 \%$ & $7.7 \%$ & $3.8 \%$ & $3.9 \%$ \\
\hline $\mathrm{N}$ & 464 & 1795 & 1665 & 402 & 549 & 706 & 592 & 292 & 300 \\
\hline
\end{tabular}

Source: ADB, authors' calculation.

Notes: shares in total sample do not add up to $100 \%$ because we do not report individual characteristics for pensioners and full time students. Standard deviations are in brackets. a Test results for significance of the difference of means between migrants and individuals who did not migrate. T-test for continuous and Z-test for binary variables

$\mathrm{b}$ Test results for significance of the difference of means between seasonal and permanent migrants. T-test for continuous and Z-test for binary variables.

${ }^{* * *} \mathrm{p}<0.01,{ }^{* *} \mathrm{p}<0.05,{ }^{*} \mathrm{p}<0.1$. 
Figure 5.1. Educational categories in occupational choices in 2006, rural areas \%

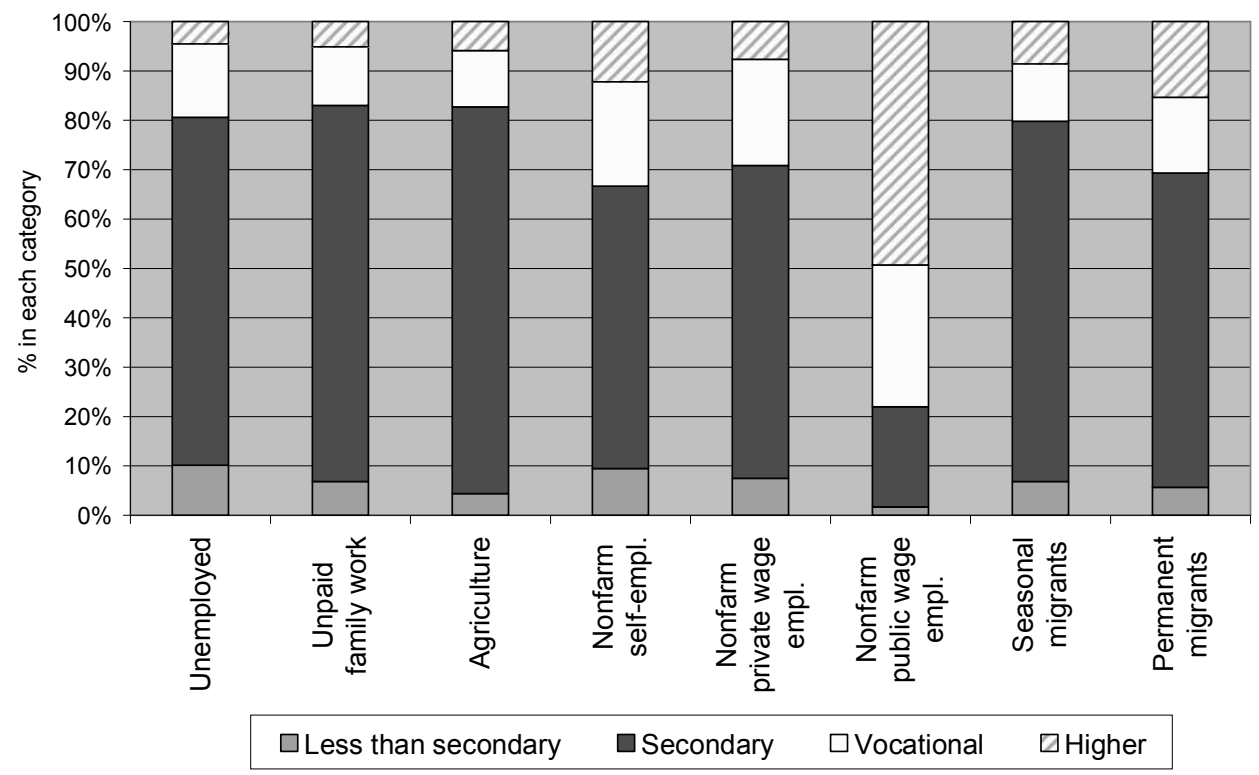

Source: ADB, authors' calculation.

Besides individual differences between migrants and non-migrants, there may be differences at the household level between those households with and without migrants. Table 5.2 contains basic information on household characteristics. The majority of households with migrants were from the South $(84.9 \%)$, and this proportion was higher for households with seasonal migrants $(89.9 \%)$ versus households with permanent migrants $(78.8 \%)$. There were significant differences in human capital among households with and without migrants. Households with migrants had larger families with more males and adults with higher education. Significant differences in human capital were also observed among permanent and seasonal migrants. Households with permanent migrants had larger families, more male adults and adults with higher education. No significant differences were found with regards to the mean size of land and the cattle stock among the considered groups. 
Table 5.2. Test for the equality of means for different characteristics of households with and without migrants, households with seasonal and permanent migrants, 2006

\begin{tabular}{|c|c|c|c|c|}
\hline & \multicolumn{2}{|c|}{$\begin{array}{c}\text { T-test and Z-test for } \\
\text { households without and } \\
\text { with migrants }\end{array}$} & \multicolumn{2}{|c|}{$\begin{array}{l}\text { T-test and Z-test for } \\
\text { households with seasonal } \\
\text { and permanent migrants }\end{array}$} \\
\hline & $\begin{array}{l}\text { Households } \\
\text { without } \\
\text { migrants }\end{array}$ & $\begin{array}{l}\text { Households } \\
\text { with } \\
\text { migrants }\end{array}$ & $\begin{array}{l}\text { Households } \\
\text { with seasonal } \\
\text { migrants }\end{array}$ & $\begin{array}{l}\text { Households } \\
\text { with } \\
\text { permanent } \\
\text { migrants }\end{array}$ \\
\hline From the Southern regions & $54.5 \%$ \%** & $84.9 \% * * *$ & $89.9 \%$ *** & $78.8 \%$ *** \\
\hline \multirow{2}{*}{$\begin{array}{l}\text { Household size (including } \\
\text { migrants) }\end{array}$} & $4.7^{* * *}$ & $5.7^{* * *}$ & $5.5^{* *}$ & $5.9^{* *}$ \\
\hline & {$[2.0]$} & {$[2.0]$} & [1.9] & [2.2] \\
\hline \multirow[t]{2}{*}{ Number of children } & $1.5^{*}$ & $1.4^{*}$ & 1.5 & 1.3 \\
\hline & [1.3] & [1.3] & [1.2] & [1.4] \\
\hline \multirow{2}{*}{$\begin{array}{l}\text { Number of male adults, }>15 \\
\text { years }\end{array}$} & $1.4^{* * *}$ & $2.2^{* * *}$ & $2.1^{*}$ & $2.3^{*}$ \\
\hline & {$[1.0]$} & {$[1.2]$} & [1.2] & [1.2] \\
\hline \multirow{2}{*}{$\begin{array}{l}\text { Number of adults with higher } \\
\text { education }\end{array}$} & $0.3^{* * *}$ & $0.5^{* * *}$ & $0.4^{* * *}$ & $0.7^{* * *}$ \\
\hline & {$[0.7]$} & {$[1.0]$} & {$[0.8]$} & [1.1] \\
\hline \multirow[t]{2}{*}{ Own land per capita, ha } & 0.2 & 0.2 & 0.2 & 0.3 \\
\hline & {$[0.4]$} & {$[0.4]$} & [0.3] & {$[0.4]$} \\
\hline \multirow{2}{*}{$\begin{array}{l}\text { Cattle initial stock, beginning } \\
\text { of } 2006\end{array}$} & 1.9 & 1.8 & 1.3 & 2.2 \\
\hline & [3.2] & [5.9] & [1.8] & [8.3] \\
\hline \multirow{2}{*}{$\begin{array}{l}\text { Cash and in-kind remittances } \\
\text { from household members }\end{array}$} & 0 & 46712.4 & $43214.2^{* * *}$ & $50276.4^{* * *}$ \\
\hline & & [54008.3] & {$[36716.4]$} & {$[67110.1]$} \\
\hline $\mathrm{N}$ & 2055 & 430 & $227(217)^{\mathrm{a}}$ & $213(203)$ \\
\hline$\%$ of total rural sample & $82.7 \%$ & $17.3 \%$ & $(8.7 \%)$ & $(8.2 \%)$ \\
\hline
\end{tabular}

Source: ADB, authors' estimation.

Note: Standard deviations are in brackets. ${ }^{* * *} \mathrm{p}<0.01,{ }^{* *} \mathrm{p}<0.05,{ }^{*} \mathrm{p}<0.1$ for T-statistic for continuous and Z-statistic for binary variables.

a We excluded 10 households which have both seasonal and permanent migrants from the estimation in last two columns.

Regarding the mean size of household income from different income sources, table 5.3 shows that income from remittances was much higher than income from any other local source. Farm income, comprising income from livestock and cropping, was slightly larger than nonfarm income from wage and self-employment.

Table 5.3. Average household rural income from remittances and local income generating activities in 2006, som

\begin{tabular}{lc}
\hline & $\begin{array}{c}\text { Average value } \\
\text { of income, som }\end{array}$ \\
\hline Crop income & $24870.0(83 \%)$ \\
Livestock income & $12269.8(69 \%)$ \\
Nonfarm self-employment & $34262.5(20 \%)$ \\
\hline
\end{tabular}




\begin{tabular}{lc}
\hline & $\begin{array}{c}\text { Average value } \\
\text { of income, som }\end{array}$ \\
\hline income & $31969.2(36 \%)$ \\
Nonfarm wage income & $53142.5^{38}(15 \%)$ \\
\hline
\end{tabular}

Source: ADB, authors' estimation.

Notes: average incomes for households having a certain income source are given. \% of households with this source is provided in brackets. Detailed explanation how incomes from different sources are calculated is provided in chapter 6, table A6.4.

In sum, there is empirical evidence that some individual and household characteristics of migrants are different from characteristics of those who stay at home, and there are differences between seasonal and permanent migrants in 2006. This indicates the selective character of migration process and justifies separate analysis for different types of migration.

\subsection{ECONOMETRIC SPECIFICATION}

Our dependent variable is a discrete variable with multiple outcomes. It measures participation of rural individuals of working age (15-65 years old) in eight categories in 2006 year: seasonal migration, permanent migration, self-employment in nonfarming, wage employment in the private nonfarm sector, wage employment in the public nonfarm sector, employment in agricultural sector, unpaid family work, unemployment. ${ }^{39}$ This broad coverage of local and foreign occupational choice allows us to compare characteristics of permanent and seasonal migrants with each other and with the characteristics of those persons who stayed at home and were active in different local income generating activities.

To account for the nature of the dependent variable, we used multinomial regression. We set agricultural employment as the base category since it provides most rural employment. This allows us to compare directly which factors are associated with participation in migration and local nonfarm activities as alternatives to employment in agriculture. One important limitation of multinomial logit is the assumption of independence of irrelevant alternatives (IIA). It means that adding another alternative or changing the characteristics of a third alternative does not affect the relative odds between alternatives. In our case this means that if, for instance, hypothetically, farm category disappears, people who were previously employed in farming would switch to other alternatives in the same proportion as other rural individuals. This may not be a very plausible assumption. Moreover, not all options are real choices in chosen categories. For

\footnotetext{
38 The difference between average size of remittances in this table and the value in table 5.2 is driven by the fact that some migrants did not send remittances home in 2006.

${ }^{39}$ We excluded from estimation full time students and pensioners.
} 
instance, unemployment category is not a choice. Nevertheless, we decided to keep this broad coverage of rural activities in multinomial logit regression, but to test robustness of our results in multinomial probit regression which does not rely on the IIA assumption. For multinomial probit regression we have removed unemployment category and combined seasonal and permanent migration in one category to achieve convergence.

We based our set of explanatory variables on the theoretical discussion from the second section and on other empirical studies (Davis et al., 2002; Mendola, 2004; Mora \& Taylor 2005). Generally, they can be divided into individual, household, and local characteristics. Following human capital theory, the group of individual characteristics includes age and its squared term, education (dummies for higher, vocational and secondary education), gender, marital status, ethnicity, and pre-migration individual status in the household (head, child). Age measures life cycle and experience. Taking into account that an average migrant is about 30 years old, we expect an inverted U-shape curve, with the propensity to migrate increasing with age at a decreasing rate.

Education is among the most important human capital variables expected to increase potential benefits from migration. We hypothesise, however, that the impact of education was stronger for permanent migrants compared to seasonal migrants, who get temporary informal jobs not requiring high qualification. We also hypothesise that being married negatively affects both the propensity of seasonal and permanent migration due to higher separation costs and costs of migration (as proposed in Stark \& Fan, 2007).

It is interesting to compare the role of education for migration with the role of education for participation in local nonfarm activities. Numerous empirical studies indicate the crucial role of education to access the rural nonfarm economy (see, for instance, Reardon et al., 2001). We demonstrated in chapter 4 that better educated individuals, especially with higher or vocational education, were more likely to choose nonfarm activities in the Kyrgyz Republic. The descriptive analysis also suggests that higher education is crucial for participation in public nonfarm employment, while vocational education is important for private nonfarm activities.

Following the NELM, we introduce also household human capital and asset variables. Human capital variables include the size of household, the number of male adults, the number of dependents (younger than 15 and older than 65 years), age and gender of household head. Larger families with more male adults are expected to have a larger propensity to migrate since losing one productive member is less costly for these households. An opposite result is expected with regard to the number of dependents, but the greater responsibility for feeding them may also "push" individuals to migrate.

It is difficult to establish the sign for the age and gender of household head a priori. Having an older head of household may increase vulnerability and thus 
stimulate migration. At the same time, very old heads of household may require care and need family members to care for the farm. Therefore, old age of the household head can constrain migration as well. Female-headed households in traditional rural societies usually do not have a male breadwinner in the family. As seasonal migration is mostly a male phenomenon, having a female head is expected to have negative impact on this type of migration.

We use land ownership and the size of owned land as crucial factors determining agricultural income and potentially important determinants of the choice between different income generating activities. Lack of land is an obvious "push" factor making an individual seek for additional sources of income as was shown in a series of studies in Latin America by Reardon et al. (2001) and by Adams (1993) for rural Egypt.

We showed in chapters 3 and 4 that a small farm size and poor quality of land were the most important factors "pushing" rural Kyrgyz residents into nonfarm activities. Similarly, lack of land may "push" rural farmers to migrate. On the other hand, as livelihood theory points out, land constraints do not only act as an incentive to start nonfarm activities or to migrate, but may also strengthen the capacity of the household to invest in such activities. Since international migration is inherently quite costly households with very small land size may be excluded from this income diversification strategy (Waddington \& Sabates-Wheeler, 2003; Reardon et al., 2006). In sum, we hypothesise that absence of owned land may stimulate both nonfarm activities and migration, while the size of land may have negative impact on propensity to migrate due to the inability of land-scarce households to finance the costs of international migration.

A final set of explanatory variables includes locational characteristics and regional dummies. The distances in kilometres to the closest road and airport at the household level, and the average hours of access to electricity in the winter period at the community level represent variables that can influence production and migration costs and the capacity to finance these costs through access to markets and infrastructure. We also included two proxies for the size of permanent migration networks and seasonal migration networks measured as the ratio of households with permanent respectively seasonal migrants who left before 2006 to the total number of households in a community in 2005, excluding observed household. Each migration network variable is expected to have a strong positive impact on the same type of migration and to have a negative effect on the other type (Pinger, 2010). In other words, the seasonal migration network is expected to stimulate seasonal migration and decrease permanent migration and vice versa.

\subsection{EMPIRICAL RESULTS}

Table 5.4 contains the relative risk ratios after multinomial logit. These are the coefficients in exponential form, which indicate how the risk of the outcome falling 
in the comparison group compared to the risk of the outcome falling in the reference group changes with the variable in question. A ratio greater than (less than) one indicates higher (lower) chances of choosing alternative employment over farm work. Independence of irrelevant alternatives is not rejected by Hausman tests, but rejected by Small-Hsiao tests (Hausman \& McFadden, 1984; Small \& Hsiao, 1985).40 Wald and likelihood-ratio tests indicate that different outcomes cannot be combined.

The empirical results demonstrate gender preferences across different strategies. Seasonal and permanent migrants were more likely to be males and the probability of migration over agriculture increased with age, but at a decreasing rate. This confirms the typical picture of migration as selective on not too young and not too old males leaving female members at home for family responsibilities (Mora \& Taylor, 2005). Males were also more likely to undertake nonfarm selfemployment, but chances of doing unpaid family work and being unemployed were higher among rural females. Interestingly, public nonfarm employment was also more probable for females. World Bank (2007) reported similar findings and showed that the health and education sectors predominantly employed educated women.

Heads of household were less likely to migrate, which might be the result of higher costs of migration due to farm specific skills and knowledge. In line with this hypothesis, heads of household had lower probability of being unemployed or doing unpaid family work over agricultural activities. In line with the predictions from Stark and Fan (2007) that higher emotional costs of separation negatively affect the decision to leave the family, married individuals were less likely to migrate.

Other things being equal, education was an important determinant of migration. However its impact was found to be different for permanent and seasonal migrants. Participation in permanent migration was more likely for people with higher education, but education did not affect the choice between seasonal migration and agricultural activities. Seasonal work abroad generally involve low-skilled jobs, which attract people with relatively low education, while better education seems to help permanent migrants to get work in formal job markets and reap the highest economic returns to their schooling. Those few studies about determinants of permanent and seasonal migration also demonstrate

\footnotetext{
${ }^{40}$ Results are available in the annex. Obtaining inconsistent results is typical for these tests and the only practical advice is to assume independence of irrelevant alternatives if you can clearly distinguish between outcome categories (Freese \& Long, 2001). As mentioned, we also estimated multinomial probit for slightly changed specification without unemployment category and combined international migration. Results are available in the annex (A5.3). Still, the obtained results from multinomial probit are similar to the results from multinomial logit and main findings hold.
} 
that permanent migrants are usually better educated than temporary ones (Joarder \& Hasanuzzaman, 2008; Pinger, 2010).

Another important finding was the strong positive impact of higher and vocational education on participation in public and private nonfarm wage employment. This means that public and private nonfarm employment competed with permanent migration for educated individuals. Moreover, better education generally helped to avoid engagement in unpaid family work in favour of agricultural activities, but did not affect the likelihood of undertaking nonfarm self-employment over agriculture.

Ownership and the size of cultivated owned land were found to have a crucial impact on participation in different activities. Landless individuals were more probable to either engage into different nonfarm activities or to migrate. This is an expected result of the lack of access to agricultural income. ${ }^{41}$

With regards to the size of land, lower land size implied a higher likelihood of participation in nonfarm activities over agriculture, indicating that poor households were pushed into nonfarm activities due to insufficient amount of agricultural income. This is in line with the results we have obtained in chapter 3 and chapter 4, namely that individual participation in and regional magnitude of nonfarm activities depended negatively on the size and quality of land. At the same time, the size of land had a positive impact, though at a decreasing rate, on chances to choose migration over staying at home and undertaking agricultural activities as we hypothesized. This can be explained by the fact that international migration is a costly strategy, requiring possession of capital to finance the costs of the trip and the initial costs of settlement.

Finally, several locational characteristics were identified as important drivers of migration in rural areas. The distance to road and airport decreased the chances of permanent and seasonal migration by increasing transportation costs. Interestingly, residing in more remote areas contributed positively to chances of being unemployed over participation in farming. Migration to resolve unemployment was thus especially important for remote areas with an underdeveloped infrastructure.

Although labour migration in the current form is a relatively new phenomenon in the Kyrgyz Republic, there have already been strong positive effects of migration networks on the probability of choosing migration over working at home in agriculture. This is in line with many empirical findings that migration networks stimulate further migration, so that migration perpetuates

\footnotetext{
${ }^{41}$ It is important to remember that virtually all rural residents in Kyrgyzstan had access to land. Those households who do not have land (about 9\% in our sample) are probably those who worked in nonfarm sectors during the Soviet time (teachers, social workers) and were not members of state collective farms. They are not poor and often have better education than those who have land.
} 
itself (Mckenzie, \& Rapoport, 2007). Moreover, as hypothesised a particular network (for seasonal or permanent migration) stimulated that particular type of migration at the cost of the other type. Similar results were found in Pinger (2010) who showed that permanent and temporary migrants made use of different types of networks.

Table 5.4. Relative risk ratios from multinomial logit, individuals of working age in rural areas, employment in agriculture is the base outcome, 2006

\begin{tabular}{|c|c|c|c|c|c|c|c|}
\hline & \multirow[b]{2}{*}{$\begin{array}{c}\text { Unemploy } \\
\text { ed }\end{array}$} & \multirow[b]{2}{*}{$\begin{array}{l}\text { Unpaid } \\
\text { family } \\
\text { work }\end{array}$} & \multicolumn{3}{|c|}{ Nonfarm employment } & \multirow[b]{2}{*}{$\begin{array}{l}\text { Seasonal } \\
\text { migrant }\end{array}$} & \multirow[b]{2}{*}{$\begin{array}{l}\text { Permanent } \\
\text { migrant }\end{array}$} \\
\hline & & & $\begin{array}{c}\text { self- } \\
\text { employme } \\
\text { nt }\end{array}$ & $\begin{array}{l}\text { private } \\
\text { sector }\end{array}$ & $\begin{array}{l}\text { public } \\
\text { sector }\end{array}$ & & \\
\hline \multicolumn{8}{|c|}{ Individual characteristics } \\
\hline Age of & $0.899^{* *}$ & $0.913^{* * *}$ & $1.164^{* * *}$ & 1.063 & $1.082^{* *}$ & $1.224^{* * *}$ & $1.223^{* * *}$ \\
\hline individual & {$[0.0371]$} & {$[0.0260]$} & {$[0.0510]$} & [0.0439] & [0.0432] & {$[0.0763]$} & [0.0619] \\
\hline $\begin{array}{l}\text { Age of } \\
\text { individual }\end{array}$ & $1.001^{*}$ & $1.001^{* * *}$ & $0.998^{* * *}$ & $0.999^{* *}$ & $0.999^{*}$ & $0.997^{* * *}$ & $0.997^{* * *}$ \\
\hline squared & {$[0.000572]$} & [0.000382] & [0.000572] & [0.000548] & {$[0.000523]$} & {$[0.000905]$} & {$[0.000702]$} \\
\hline $\begin{array}{l}\text { Dummy for } \\
\text { gender, } 1\end{array}$ & $2.089^{* * *}$ & $4.218^{* * *}$ & $0.663^{* *}$ & 0.852 & $1.975^{* * *}$ & $0.415^{* * *}$ & $0.471^{* * *}$ \\
\hline female & [0.338] & [0.532] & {$[0.124]$} & {$[0.141]$} & {$[0.332]$} & [0.0908] & {$[0.114]$} \\
\hline $\begin{array}{l}\text { Dummy for } \\
\text { marital } \\
\text { status, } 1\end{array}$ & $0.471^{* * *}$ & & $0.628^{* *}$ & 0.788 & 0.772 & 0.4 & $7^{* *}$ \\
\hline married & [0.0966] & [0.176] & [0.132] & [0.142] & {$[0.144]$} & {$[0.114]$} & [0.142] \\
\hline $\begin{array}{l}\text { Dummy, } \\
\text { head of the }\end{array}$ & $0.489^{* * *}$ & $0.436^{* * *}$ & 0.974 & 1.261 & $0.675^{* *}$ & $0.520^{* *}$ & $0.330^{* * *}$ \\
\hline household & [0.116] & {$[0.06$} & {$[0.213]$} & [0.259] & [0.133] & {$[0.156]$} & [0.103] \\
\hline Dummy, & 0.742 & $0.479^{* * *}$ & 0.906 & $1.506^{*}$ & $0.662^{*}$ & 0.883 & 1.146 \\
\hline child & [0.183] & [0.0783] & [0.245] & [0.363] & [0.150] & [0.284] & [0.305] \\
\hline $\begin{array}{l}\text { Dummy, } \\
\text { higher }\end{array}$ & 0.816 & $0.635^{*}$ & 1.429 & $1.786^{*}$ & $25.11^{* * *}$ & 1.257 & $3.667^{* * *}$ \\
\hline education & [0.288] & {$[0$} & [0.497] & [0.567] & [9.771] & [0.489] & [1.449] \\
\hline $\begin{array}{l}\text { Dummy, } \\
\text { vocational }\end{array}$ & 1.052 & $0.617^{* *}$ & 1.032 & $1.655^{*}$ & $5.700^{* * *}$ & 1.036 & $1.837^{*}$ \\
\hline education & [0.296] & [0.136] & [0.316] & [0.458] & [2.211] & [0.362] & [0.675] \\
\hline $\begin{array}{l}\text { Dummy, } \\
\text { secondary }\end{array}$ & 0.847 & 0.814 & $0.494^{* *}$ & 1.147 & 0.838 & $0.616^{*}$ & 0.932 \\
\hline education & [0.202] & [0.158] & [0.142] & [0.287] & [0.321] & [0.181] & [0.309] \\
\hline Dummy, & $0.470^{* * *}$ & $0.584^{* * *}$ & $0.628^{*}$ & $0.477^{* * *}$ & $0.624^{* *}$ & 0.854 & $0.473^{* *}$ \\
\hline Kyrgyz & [0.113] & [0.114] & [0.175] & [0.100] & [0.141] & [0.308] & [0.149] \\
\hline Dummy, & 0.669 & 1.355 & 1.278 & 0.919 & 0.757 & 1.117 & 0.749 \\
\hline Uzbek & [0.198] & {$[0.331]$} & [0.400] & [0.249] & [0.217] & [0.442] & [0.282] \\
\hline Household & zaracteristics & & & & & & \\
\hline $\begin{array}{l}\text { Age of head } \\
\text { of }\end{array}$ & $\begin{array}{c}1.011 \\
0.00697\end{array}$ & $\begin{array}{c}0.997 \\
{[0.00443]}\end{array}$ & $\begin{array}{c}0.995 \\
{[0.00731]}\end{array}$ & $\begin{array}{c}0.991 \\
{[0.00678]}\end{array}$ & $\begin{array}{l}0.996 \\
0.00600\end{array}$ & $0.978^{* *}$ & $\begin{array}{l}0.989 \\
0.00902\end{array}$ \\
\hline
\end{tabular}




\begin{tabular}{|c|c|c|c|c|c|c|c|}
\hline \multirow[b]{3}{*}{ household } & \multirow[b]{2}{*}{$\begin{array}{c}\text { Unemploy } \\
\text { ed }\end{array}$} & \multirow[b]{2}{*}{$\begin{array}{l}\text { Unpaid } \\
\text { family } \\
\text { work }\end{array}$} & \multicolumn{3}{|c|}{ Nonfarm employment } & \multirow[b]{2}{*}{$\begin{array}{l}\text { Seasonal } \\
\text { migrant }\end{array}$} & \multirow[b]{2}{*}{$\begin{array}{c}\text { Permanent } \\
\text { migrant }\end{array}$} \\
\hline & & & $\begin{array}{c}\text { self- } \\
\text { employme } \\
\text { nt } \\
\end{array}$ & $\begin{array}{l}\text { private } \\
\text { sector }\end{array}$ & $\begin{array}{l}\text { public } \\
\text { sector }\end{array}$ & & \\
\hline & & & & & & & \\
\hline $\begin{array}{l}\text { Gender of } \\
\text { the head of } \\
\text { household, }\end{array}$ & 0.972 & 0.887 & 0.922 & 1.23 & 1.209 & 1.195 & 1.372 \\
\hline 1 female & {$[0.194]$} & [0.128] & [0.213] & {$[0.220]$} & {$[0.206]$} & {$[0.270]$} & [0.327] \\
\hline Size of & 1.103 & 0.991 & $1.253^{* * *}$ & $1.191^{* *}$ & 1.089 & 1.05 & $1.251^{* * *}$ \\
\hline household & {$[0.0776]$} & {$[0.0565]$} & {$[0.0972]$} & [0.0893] & {$[0.0722]$} & {$[0.0840]$} & [0.106] \\
\hline The & 1 & 1.06 & 0.853 & $0.819^{*}$ & $0.837^{*}$ & 0.937 & $0.798^{*}$ \\
\hline $\begin{array}{l}\text { number of } \\
\text { male adults }\end{array}$ & {$[0.117]$} & {$[0.0881]$} & [0.103] & [0.0937] & [0.0798] & {$[0.114]$} & {$[0.106]$} \\
\hline $\begin{array}{l}\text { The } \\
\text { number of }\end{array}$ & 0.932 & 1.088 & $0.794^{* *}$ & $0.820^{* *}$ & $0.869^{*}$ & 0.982 & $0.749^{* * *}$ \\
\hline dependents & [0.0907] & [0.0753] & {$[0.0771]$} & {$[0.0756]$} & {$[0.0686]$} & [0.103] & [0.0828] \\
\hline $\begin{array}{l}\text { Dummy for } \\
\text { those } \\
\text { without }\end{array}$ & $1.700^{*}$ & $1.573^{* *}$ & $2.607^{* * *}$ & $1.871^{* * *}$ & $2.372^{* * *}$ & $5.380^{* * *}$ & $1.818^{*}$ \\
\hline land & {$[0.488]$} & [0.345] & [0.645] & {$[0.431]$} & {$[0.565]$} & [1.721] & [0.599] \\
\hline The size of & $0.411^{* * *}$ & $1.166^{*}$ & $0.494^{* * *}$ & $0.542^{* * *}$ & 0.979 & $2.110^{* * *}$ & $1.557^{* * *}$ \\
\hline own land & {$[0.0678]$} & {$[0.0954]$} & {$[0.0741]$} & [0.0665] & [0.0954] & [0.324] & {$[0.235]$} \\
\hline $\begin{array}{l}\text { The size of } \\
\text { own land, }\end{array}$ & $1.066^{* * * *}$ & $0.984^{*}$ & $1.042^{* * *}$ & $1.042^{* * *}$ & 0.998 & $0.936^{* * *}$ & $0.966^{* *}$ \\
\hline squared & {$[0.0130]$} & {$[0.00934]$} & [0.0143] & [0.0147] & [0.00910] & {$[0.0200]$} & [0.0134] \\
\hline Local characte & teristics & & & & & & \\
\hline $\begin{array}{l}\text { Network } \\
\text { for seasonal }\end{array}$ & $0.868^{* * *}$ & $0.960^{* * *}$ & 0.983 & $0.943^{* * *}$ & $0.963^{* * *}$ & $1.033^{* * *}$ & $0.934^{* * *}$ \\
\hline migrants & [0.0159] & [0.00868] & [0.0115] & [0.0122] & [0.00976] & [0.0113] & {$[0.0214]$} \\
\hline $\begin{array}{l}\text { Network } \\
\text { for } \\
\text { permanent }\end{array}$ & 1.003 & 1.006 & 1.012 & 0.993 & $1.017^{* *}$ & 0.988 & $1.046^{* * *}$ \\
\hline migrants & [0.00892] & {$[0.00714]$} & {$[0.00774]$} & [0.00810] & [0.00847] & [0.0107] & {$[0.00741]$} \\
\hline Distance to & 1.001 & 1 & 1 & 1 & 1 & $0.995^{* * *}$ & 0.998 \\
\hline airport, km & [0.000948] & [0.000719] & [0.00137] & [0.00127] & [0.000928] & [0.00171] & [0.00154] \\
\hline Distance to & $1.164^{* * *}$ & $0.912^{* *}$ & $0.803^{* * *}$ & 0.936 & $0.823^{* * *}$ & $0.886^{*}$ & $0.659^{* * *}$ \\
\hline road, km & [0.0547] & {$[0.0381]$} & {$[0.0674]$} & [0.0574] & [0.0425] & {$[0.0640]$} & [0.0763] \\
\hline $\begin{array}{l}\text { Average } \\
\text { hours of } \\
\text { electricity } \\
\text { in winter at }\end{array}$ & $0.929^{* * *}$ & 1.019 & 0.986 & 0.971 & 0.999 & 0.992 & 0.993 \\
\hline local level & {$[0.0243]$} & {$[0.0170]$} & {$[0.0233]$} & {$[0.0223]$} & [0.0177] & [0.0225] & [0.0257] \\
\hline $\begin{array}{l}\text { Observatio } \\
\text { ns }\end{array}$ & & & & 6171 & & & \\
\hline
\end{tabular}


Notes: ${ }^{* *} \mathrm{p}<0.01,{ }^{* *} \mathrm{p}<0.05,{ }^{*} \mathrm{p}<0.1$. For brevity we do not report coefficients for regional dummies. Employment in agriculture is the base outcome. Robust, clustered at the household level standard errors are in parentheses.

As we found that education was important both for participation in nonfarm activities and for permanent migration, it is interesting to examine the occupational status of migrants before migration. This may give an indication of which sector was most hit by the loss of human resources. As we have pre-migration occupation only for those migrants who left Kyrgyzstan in 2006, the results should be interpreted with care.

Table 5.5. Occupational status among rural individuals of working age by migration status, $\%$

\begin{tabular}{lccc}
\hline & $\begin{array}{c}\text { Non- } \\
\text { migrant } \\
\text { individuals }\end{array}$ & $\begin{array}{c}\text { Pre-migration } \\
\text { occupation of } \\
\text { seasonal } \\
\text { migrants who } \\
\text { left in 2006 }\end{array}$ & $\begin{array}{c}\text { Pre-migration } \\
\text { occupation of } \\
\text { permanent } \\
\text { migrants who } \\
\text { left in 2006 }\end{array}$ \\
\hline Employed in agriculture & $29.8 \%$ & $39.7 \%$ & $56.7 \%$ \\
Total nonfarm: & $29.7 \%$ & $6.2 \%$ & $4.7 \%$ \\
$\quad$ self-employment & $7.5 \%$ & $1.9 \%$ & $0.8 \%$ \\
$\quad$ wage employment in private & $9.5 \%$ & $1.9 \%$ & $3.9 \%$ \\
$\quad$ sector & $12.7 \%$ & $2.4 \%$ & $0.0 \%$ \\
$\quad$ wage employment in public & & & \\
$\quad$ sector & $32.2 \%$ & $39.2 \%$ & $18.1 \%$ \\
Unpaid family work & $8.3 \%$ & $14.8 \%$ & $20.5 \%$ \\
Unemployed & $100.0 \%$ & $100.0 \%$ & $100.0 \%$ \\
\hline Total & 5581 & 209 & 127 \\
$\mathrm{~N}$ & & & \\
\hline
\end{tabular}

Source: authors' estimation.

Notes: \% of individuals with different occupational status is estimated only for migrants left in 2006. \% for 2-3 columns are calculated to the total number of permanent migrants and total number of seasonal migrants left in 2006. The categories of students and pensioners are excluded from our sample of working age population.

Table 5.5 shows that the occupational structure differed between people who migrated in 2006 and the rural inhabitants who remained at home. In 2006, migration mostly absorbed people from the agricultural sector, people engaged in unpaid family work and the unemployed. Substantially fewer people left nonfarm activities. This suggests that the nonfarm economy has not experienced a substantial loss of productive people. Agriculture could be negatively affected, but we do not expect a large effect due to the considerable underemployment in this sector. 
Migration seems to have had a strong effect on decreasing rural unemployment, since there were also almost twice more unemployed among those who migrated in 2006 in comparison to non-migrants. Regarding occupational structure in separate migrant strategies, permanent migration attracted more people from agriculture, while seasonal migration seemed to attract unpaid family members. However, the direction of causality is not clear. The predominance of unpaid family members among seasonal migrants can be explained by seasonal mode of their work, which does not allow migrants to undertake formal employment.

In conclusion, both the descriptive and regression analysis shows that higher and vocational education is important for participation in permanent migration as well as in wage nonfarm employment. Yet the majority of permanent migrants who left in 2006 was from the agricultural sector. This leads to the tentative conclusion that in the considered period nonfarm activities were not much affected by a loss of educated household members. Agriculture, on the other hand, could be affected, but we have no evidence that formal education is important for this sector. Nevertheless, the loss of young and educated rural individuals, especially in case of permanent migration, may have a negative impact on local development capacity in the longer run.

\subsection{CONCLUSION}

The Kyrgyz Republic is a very interesting case for migration studies for two reasons. Firstly, migration from Kyrgyzstan and other Central Asian countries to Russia and Kazakhstan has increased since the beginning of the $21^{\text {st }}$ century. Secondly, seasonal and permanent migration have played an equally important role. There is lack of empirical evidence on determinants of migration and its role as an alternative to local nonfarm activities in Central Asian countries in particular and on the determinants of seasonal versus permanent migration in general. This chapter provides both using a representative survey from the Kyrgyz Republic.

Our analysis has identified the factors affecting the choice to work at home and to leave the country. Education was the crucial factor explaining the motives and ability of rural individuals to switch from agricultural activities either to local nonfarm activities or to international migration. However, effect of education was found to be heterogeneous across migration types and different nonfarm activities. Namely, higher and vocational education was important only for permanent migrants and for those engaged in nonfarm wage employment, but did not play a role in the choice between participation in seasonal migration, local nonfarm selfemployment and working in the local agricultural sector. This indicates that expected returns on education were higher for permanent migrants, who undertake formal employment, than for seasonal migrants, who generally engage in short-term low-skilled jobs. 
The irrelevance of better education for seasonal migrants can diminish the brain drain effect, but challenges the potentially positive transfer and application of their obtained skills and knowledge upon return. The loss of better educated permanent migrants may have a negative impact on formal employment in nonfarm activities. Yet evidence from migrants that left in 2006 suggests that only few were previously engaged in this sector.

Another important finding is related to the role of owned land. We have found that access to capital through ownership of larger land plots stimulates participation in both permanent and seasonal migration, indicating that the poorest rural individuals may be excluded from this costly strategy. In contrast, participation in private local nonfarm activities is driven by lack of land or insufficient plot size.

We thus found that better educated individuals with more land are more likely to choose permanent migration over farming, while better educated individuals with less land are more likely to choose nonfarm activities over farming. This indicates that both permanent migration and nonfarming substitute agricultural activities and may compete for the most educated rural individuals. The difference is that permanent migration option seems to be unattainable for individuals from poor households with small land holdings so they engage in local nonfarm activities, while those who are educated and have resources to finance the cost of migration choose to leave the country permanently. This may have several implications. Firstly, the distribution of benefits from migration may be skewed towards households from the upper level of the rural income distribution. Secondly, although permanent migration mostly absorbs people from the agricultural sector and not from the nonfarm economy, it may limit the development capacity of rural areas in the long run.

The obtained results also stress the importance of local nonfarm activities which are accessible for poor rural individuals, but do not necessarily generate high returns. Development of agriculture per se and investing in strengthening the capacity of rural inhabitants to move towards more remunerative local nonfarm activities may lessen migration incentives, while it is of special interest for migrant home countries to stimulate temporary migration with subsequent return of the migrants to their home country.

\subsection{ANNEX}

Table A5.1. Results from Hausman tests of IIA assumption ( $N=6171)$

\begin{tabular}{lcccc}
\hline Omitted & chi2 & df & P>chi2 & evidence \\
\hline 1 & -38.2 & 174.0 & --- & -- \\
2 & 0.0 & 2.0 & 1.0 & for Ho \\
4 & 0.0 & 2.0 & 1.0 & for Ho \\
5 & 9.5 & 172.0 & 1.0 & for Ho \\
\hline
\end{tabular}




\begin{tabular}{lcccc}
\hline 6 & 0.0 & 2.0 & 1.0 & for Ho \\
7 & 0.0 & 1.0 & 1.0 & for Ho \\
8 & 0 & 2 & 1 & for Ho \\
\hline
\end{tabular}

Table A5.2. Results from Small-Hsiao tests of IIA assumption (N=6171)

\begin{tabular}{lrrrrrr}
\hline Omitted & $\operatorname{lnL}($ full $)$ & \multicolumn{1}{c}{$\ln L($ omit $)$} & \multicolumn{1}{c}{ chi2 } & df & P>chi2 & evidence \\
\hline 1 & -3745.9 & -3600.3 & 291.1 & 186 & 0 & against Ho \\
2 & -3077.5 & -2910.6 & 333.8 & 186 & 0 & against Ho \\
4 & -3821.1 & -3659.1 & 324.0 & 186 & 0 & against Ho \\
5 & -3627.6 & -3478.2 & 298.9 & 186 & 0 & against Ho \\
6 & -3679.5 & -3522.3 & 314.4 & 186 & 0 & against Ho \\
7 & -3936.7 & -3844.3 & 184.7 & 186 & 0.5 & for Ho \\
8 & -3963.6 & -3806.2 & 314.8 & 186 & 0 & against Ho \\
\hline
\end{tabular}

Table A5.3. Results from multinomial probit, individuals of working age in rural areas, employment in agriculture is the base outcome, 2006

\begin{tabular}{lccccc}
\hline & & \multicolumn{3}{c}{ Nonfarm employment } & Internation \\
\cline { 3 - 5 } & $\begin{array}{c}\text { Unpaid } \\
\text { family work }\end{array}$ & $\begin{array}{c}\text { self- } \\
\text { employmen } \\
\text { t }\end{array}$ & $\begin{array}{c}\text { private } \\
\text { sector }\end{array}$ & $\begin{array}{c}\text { public } \\
\text { sector }\end{array}$ & $\begin{array}{c}\text { al } \\
\text { migration }\end{array}$ \\
\hline Individual characteristics & & & & & \\
Age of individual & $-0.0782^{* * *}$ & $0.0909^{* * *}$ & $0.0509^{*}$ & $0.0465^{*}$ & $0.126^{* * *}$ \\
Age of individual squared & {$[0.0213]$} & {$[0.0272]$} & {$[0.0271]$} & {$[0.0262]$} & {$[0.0285]$} \\
& $0.000871^{* * *}$ & $-0.00122^{* * *}$ & $-0.000836^{* *}$ & -0.000513 & $-0.00195^{* * *}$ \\
Dummy for gender, 1 & {$[0.000284]$} & {$[0.000357]$} & {$[0.000361]$} & {$[0.000347]$} & {$[0.000397]$} \\
female & $1.091^{* * *}$ & -0.173 & -0.0825 & $0.451^{* * *}$ & $-0.462^{* * *}$ \\
Dummy for marital & {$[0.0925]$} & {$[0.114]$} & {$[0.106]$} & {$[0.111]$} & {$[0.114]$} \\
status, 1 married & 0.109 & $-0.307^{* *}$ & $-0.215^{*}$ & -0.162 & $-0.456^{* * *}$ \\
Dummy, head of the & {$[0.109]$} & {$[0.130]$} & {$[0.121]$} & {$[0.125]$} & {$[0.128]$} \\
household & $-0.604^{* * *}$ & -0.0692 & 0.0691 & $-0.270^{* *}$ & $-0.531^{* * *}$ \\
Dummy, child & {$[0.112]$} & {$[0.136]$} & {$[0.134]$} & {$[0.132]$} & {$[0.148]$} \\
& $-0.565^{* * *}$ & -0.0564 & $0.259^{*}$ & $-0.267^{*}$ & 0.0263 \\
Dummy, higher & {$[0.121]$} & {$[0.156]$} & {$[0.149]$} & {$[0.148]$} & {$[0.142]$} \\
education & $-0.336^{*}$ & 0.34 & $0.420^{* *}$ & $2.235^{* * *}$ & $0.659^{* * *}$ \\
Dummy, vocational & {$[0.179]$} & {$[0.223]$} & {$[0.207]$} & {$[0.226]$} & {$[0.204]$} \\
education & $-0.357^{* *}$ & 0.0498 & 0.302 & $1.137^{* * *}$ & 0.254 \\
Dummy, secondary & {$[0.163]$} & {$[0.205]$} & {$[0.188]$} & {$[0.224]$} & {$[0.190]$} \\
education & -0.153 & $-0.423^{* *}$ & 0.0155 & -0.0934 & -0.15 \\
Dummy, Kyrgyz & {$[0.143]$} & {$[0.191]$} & {$[0.169]$} & {$[0.217]$} & {$[0.165]$} \\
Dummy, Uzbek & $-0.326^{* *}$ & $-0.288^{*}$ & $-0.465^{* * *}$ & $-0.310^{* *}$ & -0.272 \\
& {$[0.141]$} & {$[0.174]$} & {$[0.148]$} & {$[0.153]$} & {$[0.174]$} \\
\hline Hounnnnnn & 0.24 & 0.169 & -0.0362 & -0.156 & -0.0804 \\
& {$[0.175]$} & {$[0.196]$} & {$[0.182]$} & {$[0.191]$} & {$[0.200]$} \\
\hline
\end{tabular}

Household characteristics 


\begin{tabular}{|c|c|c|c|c|c|}
\hline & \multirow[b]{2}{*}{$\begin{array}{c}\text { Unpaid } \\
\text { family work }\end{array}$} & \multicolumn{3}{|c|}{ Nonfarm employment } & \multirow[b]{2}{*}{$\begin{array}{l}\text { Internation } \\
\quad \text { al } \\
\text { migration }\end{array}$} \\
\hline & & $\begin{array}{c}\text { self- } \\
\text { employmen } \\
\mathrm{t} \\
\end{array}$ & $\begin{array}{l}\text { private } \\
\text { sector }\end{array}$ & $\begin{array}{l}\text { public } \\
\text { sector }\end{array}$ & \\
\hline Age of head of household & $\begin{array}{l}-0.00101 \\
{[0.00344]}\end{array}$ & $\begin{array}{c}-0.00469 \\
{[0.00449]}\end{array}$ & $\begin{array}{l}-0.00736^{*} \\
{[0.00433]}\end{array}$ & $\begin{array}{l}-0.00263 \\
{[0.00399]}\end{array}$ & $\begin{array}{c}-0.00939^{* *} \\
{[0.00466]}\end{array}$ \\
\hline $\begin{array}{l}\text { Gender of the head of } \\
\text { household, } 1 \text { female }\end{array}$ & $\begin{array}{l}-0.122 \\
{[0.107]}\end{array}$ & $\begin{array}{l}-0.0482 \\
{[0.141]}\end{array}$ & $\begin{array}{c}0.13 \\
{[0.117]}\end{array}$ & $\begin{array}{c}0.159 \\
{[0.114]}\end{array}$ & $\begin{array}{c}0.189 \\
{[0.122]}\end{array}$ \\
\hline Size of household & $\begin{array}{l}-0.0125 \\
{[0.0413]}\end{array}$ & $\begin{array}{l}0.137^{* * *} \\
{[0.0466]}\end{array}$ & $\begin{array}{c}0.120^{* *} \\
{[0.0473]}\end{array}$ & $\begin{array}{c}0.0477 \\
{[0.0438]}\end{array}$ & $\begin{array}{l}0.109^{* *} \\
{[0.0436]}\end{array}$ \\
\hline $\begin{array}{l}\text { The number of male } \\
\text { adults }\end{array}$ & $\begin{array}{c}0.0527 \\
{[0.0608]}\end{array}$ & $\begin{array}{c}-0.099 \\
{[0.0735]}\end{array}$ & $\begin{array}{l}-0.142^{* *} \\
{[0.0723]}\end{array}$ & $\begin{array}{l}-0.0954 \\
{[0.0642]}\end{array}$ & $\begin{array}{l}-0.113^{*} \\
{[0.0664]}\end{array}$ \\
\hline $\begin{array}{l}\text { The number of } \\
\text { dependents }\end{array}$ & $\begin{array}{c}0.0762 \\
{[0.0510]}\end{array}$ & $\begin{array}{l}-0.134^{* *} \\
{[0.0597]}\end{array}$ & $\begin{array}{l}-0.119^{* *} \\
{[0.0588]}\end{array}$ & $\begin{array}{l}-0.0647 \\
{[0.0525]}\end{array}$ & $\begin{array}{l}-0.116^{* *} \\
{[0.0551]}\end{array}$ \\
\hline $\begin{array}{l}\text { Dummy for those without } \\
\text { land }\end{array}$ & $\begin{array}{l}0.268^{*} \\
{[0.152]}\end{array}$ & $\begin{array}{c}0.685^{* * *} \\
{[0.162]}\end{array}$ & $\begin{array}{l}0.449^{* * *} \\
{[0.156]}\end{array}$ & $\begin{array}{l}0.591^{* * *} \\
{[0.159]}\end{array}$ & $\begin{array}{l}0.834^{* * *} \\
{[0.171]}\end{array}$ \\
\hline The size of own land & $\begin{array}{c}0.105^{*} \\
{[0.0596]}\end{array}$ & $\begin{array}{c}-0.389^{* * *} \\
{[0.0841]}\end{array}$ & $\begin{array}{l}-0.386^{* * *} \\
{[0.0745]}\end{array}$ & $\begin{array}{l}-0.0361 \\
{[0.0638]}\end{array}$ & $\begin{array}{l}0.329^{* * * *} \\
{[0.0724]}\end{array}$ \\
\hline $\begin{array}{l}\text { The size of own land, } \\
\text { squared }\end{array}$ & $\begin{array}{c}-0.0127^{*} \\
{[0.00665]}\end{array}$ & $\begin{array}{l}0.0222^{* * *} \\
{[0.00782]}\end{array}$ & $\begin{array}{l}0.0255^{* * *} \\
{[0.00869]}\end{array}$ & $\begin{array}{r}-0.000778 \\
{[0.00592]} \\
\end{array}$ & $\begin{array}{c}-0.0279^{* * *} \\
{[0.00729]} \\
\end{array}$ \\
\hline Local characteristics & & & & & \\
\hline $\begin{array}{l}\text { Network for seasonal } \\
\text { migrants }\end{array}$ & $\begin{array}{l}-0.0316^{* * *} \\
{[0.00687]}\end{array}$ & $\begin{array}{l}-0.0162^{* *} \\
{[0.00712]}\end{array}$ & $\begin{array}{l}-0.0388^{* * *} \\
{[0.00760]}\end{array}$ & $\begin{array}{l}-0.0288^{* * *} \\
{[0.00662]}\end{array}$ & $\begin{array}{l}-0.00415 \\
{[0.00653]}\end{array}$ \\
\hline $\begin{array}{l}\text { Network for permanent } \\
\text { migrants }\end{array}$ & $\begin{array}{c}0.00403 \\
{[0.00502]}\end{array}$ & $\begin{array}{l}0.00965^{* *} \\
{[0.00488]}\end{array}$ & $\begin{array}{c}-0.00335 \\
{[0.00495]}\end{array}$ & $\begin{array}{c}0.0123^{* *} \\
{[0.00523]}\end{array}$ & $\begin{array}{l}0.0170^{* * *} \\
{[0.00431]}\end{array}$ \\
\hline Distance to airport, $\mathrm{km}$ & $\begin{array}{c}0.00026 \\
{[0.000550]}\end{array}$ & $\begin{array}{c}-0.000469 \\
{[0.000828]}\end{array}$ & $\begin{array}{l}-0.000135 \\
{[0.000808]}\end{array}$ & $\begin{array}{c}-0.000137 \\
{[0.000612]}\end{array}$ & $\begin{array}{l}-0.00235^{* * *} \\
{[0.000790]}\end{array}$ \\
\hline Distance to road, $\mathrm{km}$ & $\begin{array}{l}-0.0567^{*} \\
{[0.0303]}\end{array}$ & $\begin{array}{l}-0.122^{* * *} \\
{[0.0439]}\end{array}$ & $\begin{array}{l}-0.0362 \\
{[0.0374]}\end{array}$ & $\begin{array}{l}-0.142^{* * *} \\
{[0.0353]}\end{array}$ & $\begin{array}{l}-0.150^{* * *} \\
{[0.0417]}\end{array}$ \\
\hline $\begin{array}{l}\text { Average hours of } \\
\text { electricity in winter at } \\
\text { local level }\end{array}$ & {$[0.0122]$} & -0.0109 & -0.0203 & -0.00584 & $\begin{array}{l}-0.00896 \\
{[0.0125]}\end{array}$ \\
\hline Observations & & & 5707 & & \\
\hline
\end{tabular}

Notes: ${ }^{* * *} \mathrm{p}<0.01,{ }^{* *} \mathrm{p}<0.05,{ }^{*} \mathrm{p}<0.1$. For brevity we do not report coefficients for regional dummies. Employment in agriculture is the base outcome. Robust, clustered at the household level standard errors are in parentheses. 


\section{INTERNATIONAL MIGRATION, REMITTANCES AND CROP INCOME: EVIDENCE FROM THE KYRGYZ REPUBLIC ${ }^{42}$}

This chapter uses a representative household budget survey from the Asian Development Bank to analyse the impact of international migration and remittances on crop income of rural farmers in the Kyrgyz Republic in 2006. Unlike other studies, we allow the impact of remittances to be different for farmers with different land size and test whether reduced domestic labour supply is more important in the case of permanent rather than seasonal migrants. We find that losing family members due to migration has a strong negative effect on crop income, in particular in the case of permanent migration. Remittances partially compensate for this, but their positive impact decreases with farm size.

42 This chapter is based on an article co-authored with Marrit van den Berg. It is in the revise and resubmit status with World Development. 


\subsection{INTRODUCTION}

Labour migration out of rural areas has been an indispensable feature of economic development both in developed countries and in the developing world. In the last decade there has been a fundamental change in the conceptualisation and modelling of migration and development processes. Previous studies considered determinants of migration separately from the impacts of migration on sending areas. Currently, migration is viewed as a complex economic institution with close interrelationships between its determinants and its indirect effects on local rural economies (Taylor, 1999).

The New Economics of Labour Migration (NELM) played an important role in broadening the research domain by stressing the role of migration in enabling rural households to overcome credit and risk constraints and as a result to stimulate transition from familial to commercial production (Stark, 1991). Specifically, the NELM predicts that labour migration can reduce labour input the lost labour effect - and thus will have a negative impact on household farm production, but obtained remittances can compensate for this through relieving credit and insurance constraints. Two additional hypotheses can be derived from the NELM. Firstly, the positive impact of remittances is not expected to be homogeneous across farmers and will depend on how credit and risk constraints are distributed among them. For those who are more liquidity constrained the marginal positive impact of remittances is expected to be stronger (Taylor \& Wyatt, 1996). Secondly, the negative lost labour effect is not likely to be equal for seasonal and permanent migration, since the former implies regular returns home, which allows for seasonal contributions to household productive activities.

Testing of the NELM hypotheses has received relatively limited attention in empirical work and until recently most microeconomic studies dealing with the developmental impact of migration and remittances have focused on poverty and inequality in source areas (Lokshin \& Glinskaya, 2008). Exceptional studies about the general impact of migration and remittances on household farm income and agricultural productivity include Lucas (1987), Taylor and Wyatt (1996), Taylor et al. (2003), and de Brauw (2010). To the best of our knowledge, only Taylor and Wyatt (1996) have checked for differences in the effects of remittances for households with different asset endowments and thus different liquidity and insurance positions. We have not seen studies distinguishing the lost labor effect for crop income of permanent and seasonal migrants.

This chapter contributes to the existing realm of migration literature testing the NELM by providing new empirical evidence on the developmental impact of labour migration and remittances on crop income in a transition country with a predominantly rural economy and large numbers of both seasonal and permanent migrants: Kyrgyzstan. We test whether the impact of remittances is different across farmers with different amounts of owned usable land, because they may encounter 
different constraints to invest in crop production and different incentives/capacity to migrate. Finally, we check whether permanent migrants have a stronger negative lost labour impact on crop income than seasonal migrants. Our work is based on the representative household budget survey in the Kyrgyz Republic, conducted by the Asian Development Bank.

Central Asia is a region where international labour migration and remittances have played an important role in recent years (Mansoor \& Quillin, 2006). The Kyrgyz Republic is an interesting case to explore. The most recent studies show that international labour migration had an important effect on the wellbeing of local households, especially in rural areas, which are characterised by small-scale individual farming with high seasonality, widespread poverty, slowing agricultural growth and an increasing role of local nonfarm activities (World Bank, 2007; ADB, 2008a; Atamanov \& van den Berg, 2010). However, the role of migration and remittances in crop production, the most important source of rural income, has not been researched yet. Permanent and seasonal migration are equally important, which makes the Kyrgyz Republic a suitable case study for testing the hypothesised differences in the lost labour effect.

The chapter continues as follows. Firstly, we present theoretical framework. Secondly, we describe the data used. Then we discuss the empirical strategy. Finally, we present empirical results, followed by conclusions.

\subsection{THEORETICAL FRAMEWORK}

The analysis of migration has a long history and covers both the determinants and the effects of migration on source and host countries and communities. Early classical models by Lewis (1954), Ranis and Fei (1961) and Todaro (1969) considered migration decisions as carried out by individuals and shaped by existing or expected differences in income between migrant origins and destinations and did not pay attention to remittances.

This framework started to change in the 1980s and 1990s with the development of the NELM, which linked causes and consequences of migration explicitly in one model (Stark, 1991). Several important changes were introduced along with this theory. Firstly, the NELM considers a migration act as a decision taken by the entire household together for its wellbeing as a whole. The household wants to maximise joint income and status and to minimise risks in this model. Migration can help to loosen constraints caused by different market failures, such as incomplete capital, insurance and labour markets (Martin \& Taylor, 1999). Secondly, the NELM links remittances with migration in one framework, where remittances serve as income insurance for households of origin. This theory has conceptual overlap with livelihood approaches, which consider migration as a part of broader household livelihood strategy to diversify income sources and overcome different constraints at the places of origin (De Haas, 2010). 
The NELM perspective significantly broadened the research focus with regard to the potential impacts of migration and remittances in rural areas. In particular, it provides a framework to analyse the impact of labour migration on income generating activities of remaining household members. Formal theoretical models were presented in Taylor et al. (2003) and Wouterse and Taylor (2008). According to these authors, a household can choose between low-returns and high-returns local activities (for instance, farm versus nonfarm, low-return cropping activity versus high return cropping, food crop versus cattle breeding, and so forth). The household has only fixed resources to invest into the chosen income generating activities, and in case of market imperfections (e.g. imperfect credit markets) it is constrained from investing in the high-returns activity. This will either inhibit the household from entering into higher-returns activities or will not allow for producing output at the optimal level. As explained in more detail below, the role of migration in this case is twofold: it decreases the number of family workers but may result in remittances sent home by the migrants.

The loss of labour due to migration can constrain local income-generating activities generating the lost labour effect. The relevance and size of this effect depends on the general conditions in the labour market, the main employment sectors of the remaining household members, the previous occupation of migrants and the extent to which family labour can be replaced by external workers. If, as often the case with agricultural activities in rural areas of developing countries, a household relies on family labour and there are seasonal labour shortages it may be quite difficult to replace the departed member of the household by a hired worker. This can generate a substantial lost labour effect on local farm income which was demonstrated in empirical studies. Lucas (1987) showed that labour migration from five African countries to South Africa reduced crop production. Taylor et al. $(1999,2003)$ found a strong direct negative impact of migration on cropping income in general and maize yields in particular in China. De Brauw (2010) found that households with migrants decreased rice production and shifted to less labour intensive crops in Vietnam.

The negative lost labour effect can be (partly) compensated by remittances, which relax household liquidity and insurance constraints. A positive impact of remittances on crop income and agricultural productivity was found in Taylor et al. (1999, 2003). Taylor and Wyatt (1996) hypothesise in line with the NELM that the marginal impact of remittances on income will be different for households with different initial assets endowments, which will determine their demand and access to liquidity and insurance. For those who have few liquid assets and require substantial additional inputs or those whose assets do not generate enough resources to self-finance current or more productive activities, the propensity to migrate and the liquidity and income-insurance effects of remittances will be higher. 
Taylor and Wyatt's research based on Mexico supports the proposition about heterogeneous effects of remittances on farm income depending on the distribution of liquidity constraints in the form of an asset which requires complementary investment, but does not provide access to financing or insurance. They hypothesise that remittances should have stronger impacts in farms with large amounts of illiquid nonmarketable land and weaker impacts in farms with large stocks of liquid livestock. In line with these hypotheses, the authors found a significant positive impact of remittance-nonmarketable ejido land interactions and a significant negative impact of remittance-livestock interactions on farm income (Taylor \& Wyatt, 1996).

While remittances can thus stimulate local production through their impact on liquidity and insurance, they may also dampen the incentives to work of remaining family members by increasing the reservation wage and decreasing the opportunity cost of leisure (see, for example, Amuedo-Dorantes \& Pozo, 2006). The resulting lower labour efforts will diminish the potentially positive effect of remittances on agricultural productivity and crop income.

The theoretical literature on the impact of migration and remittances on local income generating activities does not distinguish between permanent and seasonal moves. However, since seasonal migration usually implies cyclic, shortterm moves for predetermined periods that allow workers to return home to help household members on their farms, we hypothesise that it does not necessarily induce the lost labour effect on agricultural activities or at least negative effect need not be strong (see a similar discussion in Görlich \& Trebesch, 2008). Permanent migrants, in contrast, may have a stronger negative impact on local income sources in case family labour cannot be substituted by external workers.

In conclusion, the net effect of migration on household agricultural income is an empirical question and depends on the magnitude of the separate effects of lost labour and remittances and the local context. The effect is not likely to be zero in developing areas with severe market imperfections, as it would be in a situation with perfect markets, where migration is expected to affect household consumption through the direct effect of remittances on income and the lost labour can be substituted by hired workers from the local labour market (Taylor et al., 2003).

\subsection{DATA DESCRIPTION}

The data used for the analysis are part of the household survey on remittances and poverty conducted in the Kyrgyz Republic in early 2007 in the framework of the Asian Development Bank project “A Study on International Migrants' Remittances in Central Asia and South Caucasus". The target sample was 4200 households, but the actual number was 3997 households divided into three strata: capital, other urban areas, and rural areas proportionally to their share in the total number of 
household in each category. This procedure formed three representative samples at the country, rural and urban level. It also allows for estimating indicators at the community level.

As we are interested in the impact of migration and remittance on crop income, we formed a subsample of the 1836 rural households engaged in cropping and owning at least $0.1 \mathrm{ha}^{43}$ of owned usable land per household. We divided this sub-sample into 4 quartiles based on own land per capita. Households in the first quartile owned on average 0.05 ha per capita, in the second 0.13 ha per capita, in the third 0.24 ha per capita, and finally households in the fourth quartile owned on average 0.69 ha of land per capita.

We consider people as migrants who were members of the household before going abroad, and who would have been a member of the household in 2006 if they had stayed in the country. There is no clear indication as to how interviewers and respondents distinguished between seasonal and permanent migrants. The questionnaire just contains a direct question if he/she is a seasonal migrant or not. Most probably seasonal migrants are those who go abroad for a predetermined period of time less than one year and return home regularly.

In the selected sub-sample of rural households $17 \%$ of the households (312 observations) had international labour migrants. 167 households had seasonal migrants and 153 households had permanent migrants. Eight households had both permanent and seasonal migrants. Households with permanent migrants had larger families, more males and more adults with higher education than households without migrants or with seasonal migrants. Most migrants were employed abroad in construction and trade. There were more construction workers among seasonal than among permanent migrants.

Table 6.1. Distribution of households with migrants across land per capita quartiles in 2006, \%

\begin{tabular}{lcccc}
\hline \% of household with: & I & II & III & IV \\
\hline Migrants & 14.3 & 18.6 & 20.9 & 14.2 \\
Permanent migrants & 7.9 & 8.7 & 8.3 & 8.4 \\
Seasonal migrants & 6.4 & 10.5 & 13.4 & 6.0 \\
\hline Landownership per & & & & \\
capita, ha & 0.05 & 0.13 & 0.24 & 0.69 \\
\hline
\end{tabular}

Source: ADB, authors' calculation.

Notes: The percentages do not add up because some households have both permanent and seasonal migrants.

Relatively many migrants came from the middle range of the land distribution, i.e. from the second and third quartile of land per capita (table 6.1). Households from

${ }^{43}$ We also excluded several observations with extremely high land sizes and crop income. 
the lowest quartile, on the other hand, often complement crop and livestock income by participation in nonfarm self-employment activities and wage employment. Large farmers get a relatively large share of income from livestock production and use credit more often than others do (table 6.2).

Table 6.2. Income shares, total income per capita and the use of credit resources across land per capita quartiles, 2006

\begin{tabular}{|c|c|c|c|c|c|c|c|}
\hline $\begin{array}{l}\text { Land per } \\
\text { capita } \\
\text { quartiles }\end{array}$ & $\begin{array}{c}\text { Share of } \\
\text { crop } \\
\text { income }\end{array}$ & $\begin{array}{c}\text { Share of } \\
\text { livestock } \\
\text { income }\end{array}$ & $\begin{array}{c}\text { Share } \\
\text { of } \\
\text { wage }\end{array}$ & $\begin{array}{l}\text { Share of } \\
\text { income } \\
\text { from self } \\
\text { employm } \\
\text { ent }\end{array}$ & $\begin{array}{l}\text { Share of } \\
\text { remittan } \\
\text { ces }\end{array}$ & $\begin{array}{c}\text { Total } \\
\text { income } \\
\text { per } \\
\text { capita }\end{array}$ & $\begin{array}{l}\text { Used credit in } \\
2006 \text { from } \\
\text { banks, credit } \\
\text { unions and } \\
\text { micro } \\
\text { financial } \\
\text { organisations }\end{array}$ \\
\hline $\mathrm{I}$ & $31 \%$ & $19 \%$ & $22 \%$ & $10 \%$ & $7 \%$ & 11035 & $4 \%$ \\
\hline II & $39 \%$ & $18 \%$ & $11 \%$ & $9 \%$ & $10 \%$ & 11585 & $5 \%$ \\
\hline III & $45 \%$ & $17 \%$ & $10 \%$ & $5 \%$ & $11 \%$ & 14639 & $5 \%$ \\
\hline IV & $44 \%$ & $26 \%$ & $10 \%$ & $4 \%$ & $6 \%$ & 20186 & $9 \%$ \\
\hline Total & $40 \%$ & $20 \%$ & $13 \%$ & $7 \%$ & $9 \%$ & 14342 & $6 \%$ \\
\hline
\end{tabular}

Source: ADB data, authors' calculation.

Notes: Other income is not presented in the table.

Total crop income is lower for households with migrants than for households without migrants for all land per capita quartiles, but especially so for the top quartile (table 6.3). For the smaller farms, this effect seems to be moderated by the presence of remittances, although only slightly.

Table 6.3. Total crop income for households with and without migrants across land per capita quartiles, $2006(\mathrm{~N}=1836)$

\begin{tabular}{lcccc}
\hline $\begin{array}{l}\text { Land per } \\
\text { capita } \\
\text { quartiles }\end{array}$ & $\begin{array}{c}\text { No } \\
\text { migrants }\end{array}$ & Migrants & $\begin{array}{c}\text { No } \\
\text { remittances }\end{array}$ & Remittances \\
\hline I & 15670 & 13181 & 15504 & 13967 \\
II & 19483 & 17096 & 19376 & 17426 \\
III & 28383 & 25068 & 28178 & 25634 \\
IV & 47745 & 26802 & 47589 & 22694 \\
\hline All & 27842 & 20750 & 27749 & 20349 \\
\hline
\end{tabular}

Source: ADB data, authors' calculation.

Notes: The difference between no migrants and no remittances is due to the fact that some migrants did not send remittances home.

Similarly, all but the smallest farms receiving remittances have lower crop income per ha than comparable farmers without remittances, and farmers in the first quartile on average rent-in land only if they do not have remittances (table 6.4). On the other hand, farmers receiving remittances have higher yields and fertiliser 
expenditures. This can be related to contrasting effects of migration and remittances, with fertilisers substituting for lost family labour. Small farmers are substantially more productive based on crop income per harvested area, potatoes and wheat yields. They also have higher expenditures on fertilisers per harvested area than larger farmers have. Several other authors also demonstrate that small household farms outperform large farms and more efficient (Akramov \& Omuraliev, 2009; Lerman \& Sedik, 2009ab). In sum, there is preliminary evidence that in general households with remittances have higher productivity and use more fertilisers but have lower crop income and that small landowners are more productive than larger landowners.

Table 6.4. Mean values for inputs, land productivity and income for households with and without remittances across land per capita quartiles, 2006

\begin{tabular}{|c|c|c|c|c|c|c|}
\hline $\begin{array}{c}\text { No/yes } \\
\text { remittan } \\
\text { ces }\end{array}$ & $\begin{array}{c}\text { Land } \\
\text { quarti } \\
\text { les } \\
\end{array}$ & $\begin{array}{c}\text { Crop income } \\
\text { per } \\
\text { harvested } \\
\text { ha, som } \\
\end{array}$ & $\begin{array}{l}\text { Fertilisers } \\
\text { per } \\
\text { harvested } \\
\text { ha, som } \\
\end{array}$ & $\begin{array}{c}\text { Potatoes } \\
\text { yield per } \\
\text { harvested } \\
\text { ha, kg }\end{array}$ & $\begin{array}{c}\text { Wheat } \\
\text { yield per } \\
\text { harvested } \\
\text { ha, kg } \\
\end{array}$ & $\begin{array}{l}\text { Harvest } \\
\text { ed area } \\
\text { to own } \\
\text { land, \% }\end{array}$ \\
\hline \multirow{5}{*}{$\begin{array}{l}\text { No } \\
\text { remittan } \\
\text { ces }\end{array}$} & 1 & 64076 & 1659 & 11414 & 2748 & $157 \%$ \\
\hline & 2 & 38222 & 1496 & 10767 & 2613 & $100 \%$ \\
\hline & 3 & 31835 & 946 & 9332 & 2309 & $95 \%$ \\
\hline & 4 & 26282 & 403 & 9718 & 1973 & $85 \%$ \\
\hline & Total & 40396 & 1124 & 10325 & 2312 & $110 \%$ \\
\hline \multirow{5}{*}{$\begin{array}{l}\text { Remitta } \\
\text { nces }\end{array}$} & 1 & 56696 & 1446 & 10809 & 2898 & $100 \%$ \\
\hline & 2 & 35424 & 1906 & 12991 & 2847 & $95 \%$ \\
\hline & 3 & 28014 & 1613 & 11713 & 3111 & $101 \%$ \\
\hline & 4 & 24882 & 1050 & 9049 & 2323 & $80 \%$ \\
\hline & Total & 35530 & 1555 & 11387 & 2842 & $95 \%$ \\
\hline \multirow{5}{*}{ Total } & 1 & 63161 & 1633 & 11347 & 2778 & $150 \%$ \\
\hline & 2 & 37740 & 1567 & 11147 & 2667 & $99 \%$ \\
\hline & 3 & 31101 & 1074 & 9715 & 2528 & $96 \%$ \\
\hline & 4 & 26124 & 476 & 9664 & 2013 & $84 \%$ \\
\hline & Total & 39664 & 1189 & 10459 & 2417 & $108 \%$ \\
\hline
\end{tabular}

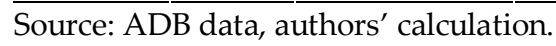

Notes: Potatoes and wheat yields are estimated only for those who grow these crops.

We hypothesised in the theoretical part that the lost labour effect is less pronounced for seasonal migrants who return home regularly. However, this depends on how the timing of the occupation abroad relates to work at home and what role migrants played for household income before departure. Unfortunately, we do not know when migrants leave and return home. Yet the construction and trade sectors in Russia, where most migrants work, have the peak of activities in the warm months, just like Kyrgyz agriculture. This overlap in seasonality may challenge our proposition about a limited lost labour effect for seasonal migrants even when they return home regularly every year. 
Table 6.5. Occupational status among rural individuals of working age by migration status, $\%$

\begin{tabular}{lccc}
\hline & $\begin{array}{c}\text { Non- migrant } \\
\text { individuals }\end{array}$ & $\begin{array}{c}\text { Pre-migration } \\
\text { occupation of } \\
\text { seasonal } \\
\text { migrants left in } \\
2006\end{array}$ & $\begin{array}{c}\text { Pre-migration } \\
\text { occupation of } \\
\text { permanent } \\
\text { migrants left in } \\
2006\end{array}$ \\
\hline Employed in agriculture & $34 \%$ & $48 \%$ & $64 \%$ \\
Employed in nonfarm & $24 \%$ & $4 \%$ & $3 \%$ \\
activities & $34 \%$ & $38 \%$ & $19 \%$ \\
Unpaid family work & $8 \%$ & $10 \%$ & $14 \%$ \\
Unemployed & $100 \%$ & $100 \%$ & $100 \%$ \\
\hline Total & 4386 & 154 & 93 \\
$\mathrm{~N}$ & & &
\end{tabular}

Source: authors' estimation.

Notes: \% of individuals with different occupational status is estimated only for migrants left in 2006. \% for 2-3 columns are calculated to the total number of permanent migrants and total number of seasonal migrants left in 2006. Students and pensioners are excluded.

For migrants who left in 2006, the main pre-migration occupation was in the agricultural sector, followed by unpaid family work and being not employed. The picture is different for seasonal and permanent migrants. More permanent migrants were working in agriculture, while there were more individuals doing unpaid family work among the seasonal migrants. Therefore, the expected stronger lost labour effect for permanent migrants can be also caused by their higher pre-migration occupation in the agricultural sector.

\subsection{EMPIRICAL STRATEGY}

To assess the impact of migration and remittances on crop income, we closely follow the approach of Taylor et al. (2003), who estimated the impact of migration and remittances based on three equations for a constrained vector of income sources, remittances and the number of migrants in rural areas. As we want to control for the impact of remittances depending on the size of land and to separate lost labour effects of permanent and seasonal migration, we expand this model and estimate three different specifications (see table 6.6). In the first specification we use total number of migrants and remittances. In the second specification we add

\footnotetext{
${ }^{44}$ Data from table 6.5 are different from the data in table 5.5 because we use different rural sub-samples. For table 6.5 we used rural individuals from households engaged in cropping and having at least 0.1 ha of owned land.
} 
the interaction of remittances with land. Finally, we split the total number of migrants into seasonal and permanent migrants. ${ }^{45}$ The adapted model is as follows:

$$
\begin{aligned}
& Y=\alpha_{1 k}+\alpha_{2} M_{p}+\alpha_{3} M_{s}+\left(\alpha_{4}+\alpha_{5} L\right) R+\alpha_{6} Z+\varepsilon_{k}, \\
& R=\beta_{1}+\beta_{2} M_{p}+\beta_{3} M_{s}+\beta_{4} Z+\varepsilon_{r}, \\
& M_{p}=\delta_{1}+\delta_{2} Z+\varepsilon_{p}, \\
& M_{s}=\gamma_{1}+\gamma_{2} Z+\varepsilon_{s},
\end{aligned}
$$

where $\mathrm{Y}$ is crop income in 2006. $\mathrm{M}_{\mathrm{p}}$ and $\mathrm{M}_{\mathrm{s}}$ the number of permanent and seasonal international migrants. $\mathrm{R}$ is amount of cash and in-kind remittances received from migrants abroad and $\mathrm{L}$ is the size of owned land in ha.

We use land as the main asset because its size is the most important factor determining the magnitude of crop income. The size of owned land is unlikely to be affected by remittances due to the imperfections in land market in Kyrgyzstan: land is rarely sold but there is quite an active land rental market.

$\mathrm{Z}$ is a vector of individual, household and local characteristics to explain crop income, the size of remittances, and the number of migrants. For all three regressions we include the household size, the share of adults with higher education, the share of male adults, gender and age of the head of household, a dummy if the head of household has higher education, dummies for Kyrgyz and Uzbek ethnicity, minutes needed to get to the closest road and market, average time households have access to clean water in summer time at the local level, six regional dummies, and a number of instrumental variables discussed below. As our descriptive analysis revealed an inverse U-shaped relationship between the number of migrants and the size of land, we use dummies for three land quartiles in migration and remittances equations to better capture non-linearity. A detailed description of variables is presented in the annex.

As the number of migrants is an endogenous variable, we need instruments for consistent estimation. Migration networks or contacts are frequently used for this purpose, since they help to decrease the costs of migration and increase opportunities for migration (see, for example, Taylor et al., 2003). We construct two variables as proxies for rural migration networks: the shares of households with seasonal and permanent migrants to the total number of rural households at the community level in 2005, omitting observed household. Like

\footnotetext{
${ }^{45}$ We assume that the lost labour effect is constant across farmers with different land size. This may not be a plausible assumption because the loss of productive members may affect land-abundant farms most. Nevertheless, due to estimation complexity and our focus on remittances we maintain this assumption. The results can be interpreted as the average labour loss effect across farms.
} 
Taylor et al. (2003), we hypothesise that these migration networks at the community level affected the number of migrants at the household level in 2006 through lowering costs of migration, but did not have a direct impact on crop income and were not correlated with unobservable characteristics at the household level.

We also need instruments for the size of remittances and their interaction with land. We again follow Taylor et al. (2003) and construct a proxy for the local norm to remit as an average level of cash and in-kind remittances per migrant among rural households at the community level in 2006, omitting the observed household. The norm to remit is used to instrument received remittances at the household level, while its interaction with land size is used to instrument the interaction of land and remittances.

To account for potential contemporaneous correlation across crop income, remittances and unobserved common shocks, all equations are estimated simultaneously as a recursive system of equations. In order to do so we use a special program developed by Roodman (2009) to estimate fully observed recursive mixed-process models. As this program provides only limited possibility to test the validity of the instruments, we also estimated the crop income equation using 2SLS regression.

\subsection{RESULTS}

Table 6.6 presents the results for the crop income equations using the two estimation methods. We discuss the results based on the system of equations, because the 2SLS regressions are used to test the instruments. The other stages from the system of equations are presented in the annex, followed by different tests available from the 2SLS regressions. All instruments are found to be significant across specifications and they pass weak under-identification and weak instruments tests (table A6.3 in the annex).

Table 6.6. Regression results for crop income in 2006, three specifications based on recursive system of equations and IV regressions $(\mathrm{N}=1836)$

\begin{tabular}{lcccccc}
\hline & \multicolumn{2}{c}{ Recursive systems regression } & \multicolumn{3}{c}{ 2SLS regression } \\
\hline & I & II & III & I & II & III \\
\hline Total number of & $-33297^{* *}$ & $-30547^{* *}$ & & $-22679^{* *}$ & $-21637^{* *}$ & \\
migrants & {$[15735]$} & {$[13016]$} & & {$[9610]$} & {$[10454]$} & \\
Total remittances, & $0.205^{* *}$ & $0.977^{* * *}$ & $0.832^{* * *}$ & $0.287^{* *}$ & $0.751^{* * *}$ & 0.469 \\
som & {$[0.0903]$} & {$[0.282]$} & {$[0.232]$} & {$[0.128]$} & {$[0.284]$} & {$[0.296]$} \\
Total & & $-0.589^{* *}$ & $-0.564^{* *}$ & & $-0.490^{*}$ & $-0.532^{*}$ \\
remittances*own & & & & & & \\
land size & & {$[0.302]$} & {$[0.273]$} & & {$[0.256]$} & {$[0.278]$} \\
Number of seasonal & & & -23422 & & & 8706 \\
migrants & & & {$[17501]$} & & & {$[13501]$} \\
Number of & & & $-38198^{* *}$ & & & -16298 \\
\hline
\end{tabular}




\begin{tabular}{|c|c|c|c|c|c|c|}
\hline & \multicolumn{3}{|c|}{ Recursive systems regression } & \multicolumn{3}{|c|}{ 2SLS regression } \\
\hline & $\mathrm{I}$ & II & III & $\mathrm{I}$ & II & III \\
\hline permanent migrants & & & [15588] & & & [10266] \\
\hline \multirow[t]{2}{*}{ Household size } & $3038^{* * *}$ & $2940^{* * *}$ & $2813^{* * *}$ & $2238^{* * *}$ & $2669^{* * *}$ & $2267^{* * *}$ \\
\hline & [979.1] & [700.9] & [714.8] & [626.6] & [722.1] & [717.1] \\
\hline Share of male adults & $20672^{* *}$ & $15945^{* *}$ & $14213^{* *}$ & $14351^{* * *}$ & $13717^{* *}$ & 9362 \\
\hline in the household size & {$[8445]$} & [6200] & [6051] & [5107] & [5697] & [5704] \\
\hline $\begin{array}{l}\text { Share of adults with } \\
\text { higher education in }\end{array}$ & 9634 & 8497 & 10502 & 5804 & 7582 & 11384 \\
\hline the households size & [8011] & [9310] & [9627] & [6978] & [8351] & [9464] \\
\hline Head of the & 293.6 & 283.6 & 303.9 & 198.9 & 260.5 & 243.4 \\
\hline household age & [281.3] & [292.1] & [284.6] & [254.1] & [267.6] & [268.3] \\
\hline $\begin{array}{l}\text { Head of the } \\
\text { household age }\end{array}$ & -2.777 & -2.682 & -2.812 & -1.921 & -2.444 & -2.302 \\
\hline squared & {$[2.554]$} & [2.647] & [2.594] & [2.299] & [2.411] & [2.431] \\
\hline $\begin{array}{l}\text { Head of the } \\
\text { household gender, }\end{array}$ & -498.6 & -1028 & -1430 & -2595 & -2114 & -3299 \\
\hline male is the base & [2971] & [2403] & [2410] & [1856] & [2073] & [2126] \\
\hline $\begin{array}{l}\text { Head of the } \\
\text { household has }\end{array}$ & -1342 & -773.3 & -1116 & -1041 & -382.9 & -875.4 \\
\hline higher education & [3172] & [3317] & [3208] & [2951] & [3105] & [3000] \\
\hline Dummy, Kyrgyz & $-6733^{*}$ & $-6603^{*}$ & $-6865^{*}$ & $-6536^{*}$ & -5074 & -5280 \\
\hline & [3500] & [3521] & [3537] & [3431] & [3562] & [3690] \\
\hline Dummy, Uzbek & $-10986^{* * * *}$ & $-10815^{* * * *}$ & $-10873^{* * *}$ & $-10151^{* * *}$ & $-9472^{* *}$ & $-9783^{* *}$ \\
\hline & [3676] & [3780] & [3787] & [3471] & [3709] & [3887] \\
\hline $\begin{array}{l}\text { Mean hours of access } \\
\text { to clean water in }\end{array}$ & $345.1^{* * *}$ & $240.3^{* * * *}$ & $249.6^{* * *}$ & $305.2^{* * *}$ & $244.0^{* * *}$ & $299.9^{* * *}$ \\
\hline summer at local level & [82.37] & [90.57] & [92.02] & [73.61] & [82.57] & [89.50] \\
\hline $\begin{array}{l}\text { Minutes needed to } \\
\text { get to the closest }\end{array}$ & $-252.6^{* * *}$ & $-217.2^{* *}$ & $-195.1^{*}$ & $-224.9^{* * *}$ & $-184.7^{* *}$ & -106.6 \\
\hline road & [96.27] & [109.2] & [106.1] & [81.52] & [87.17] & [92.06] \\
\hline Size of own land, ha & $\begin{array}{c}14078^{* * *} \\
{[3381]}\end{array}$ & $\begin{array}{c}16351^{* * *} \\
{[2947]}\end{array}$ & $\begin{array}{c}16107^{* * *} \\
{[3071]}\end{array}$ & $\begin{array}{c}11799^{* * *} \\
{[2109]}\end{array}$ & $\begin{array}{c}10999 * * * \\
{[2705]}\end{array}$ & $\begin{array}{c}10666^{* * *} \\
{[3034]}\end{array}$ \\
\hline Size of own land & -193.7 & -193.6 & -177.2 & -62.01 & 339.9 & 412.3 \\
\hline squared & {$[320.8]$} & [217.6] & [224.6] & [264.9] & [297.8] & {$[337.8]$} \\
\hline Centred R-squared & & & & 0.315 & 0.273 & 0.22 \\
\hline
\end{tabular}

Notes: ${ }^{* * *} \mathrm{p}<0.01,{ }^{* *} \mathrm{p}<0.05,{ }^{*} \mathrm{p}<0.1$. Results for regional dummies are not reported for brevity. Robust standards errors are in parentheses. First stage regressions from the recursive system and tests for instruments are presented in the annex in tables A6.1, A6.2 and A6.3.

We find that the proxies for separate networks substitute each other. Thus, the permanent network stimulates permanent migration, but has a disincentive effect on seasonal migration. The same result holds for the seasonal network. Therefore, the presence of one prevailing type of migration network will induce that 
particular type of migration (similar findings are in chapter 5 and Pinger, 2010). Another interesting finding is that there were more migrants from households with larger size of land. This may indicate that those with small size of land can not overcome entry barriers to participate in costly international migration. We also find that only permanent migration was associated with a larger share of adults with higher education in the household. This suggests that only permanent migration offers attractive returns on education. Family and the availability of male labour increase the number of migrants, while distance to roads is negatively related to migration, probably through higher costs.

Turning to the crop income equation, we find that migration of labour had a relatively large negative impact on crop income. When distinguishing between the two types of migrants, we find that the lost labour effect was only significant for permanent migrants. This finding is important and demonstrates that at least in the case of seasonal migrants, the lost labour did not affect crop income. ${ }^{46}$ This may be because seasonal migrants return home regularly and contribute to crop production, but in the case of the Kyrgyz Republic it can be also due to the fact that many seasonal migrants did not contribute much to agricultural activities before migration.

While the lost labour effect was high -one migrant decreased crop income by somewhat more than 33,000 som or slightly more than average crop incomehouseholds with migrants did not give up crop production altogether. Remittances at least partly compensated for the lost labour by increasing crop income with 0.21 som per som of remittances on average. The positive impact of remittances became weaker with increasing land size. This suggests that small farmers were more liquidity constrained than households with a relative abundance of land. Alternatively, remittances may have a negative effect on work incentives for households that are already relatively well-off. Ultimately, this could even result in a decrease in crop income compared to a situation without migrants and remittances.

In sum, our research found empirical evidence in support of the NELM hypothesis about opposite effects of migrants and remittance on household crop income. Moreover, remittances were found to play a more important role for small farms than for large farms, and the departure of seasonal migrants was found to have a negligible impact on local crop production in contrast to the permanent leave of household labour, which substantially decreased crop income.

\footnotetext{
${ }^{46}$ For information we also estimated how migration and remittances affect total earned income consisting of crop income, cattle income, and nonfarm income in 2006. The results are presented in the annex (table A6.5). One can see that positive effect of remittances on total earned income disappears, but negative effect of lost labour holds. Therefore, in overall net effect of migration and remittances on the household income seems to be negative.
} 


\subsection{CONCLUSION}

International labour migration and remittances started playing an important role in poor Central Asian countries after 2000. Kyrgyzstan became an important supplier of labour migrants to the Russian Federation and one of the largest recipients of remittances in terms of the share to GDP in the former Soviet Union. This paper analyses the impact of international migration and remittances on crop income of rural farmers in the Kyrgyz Republic. We hypothesised in line with the NELM that migration decreases crop income due to the lost labour effect, while received remittances relieve different constraints and increase crop income. In addition, we tested whether the positive impact of remittances is heterogeneous across different farm sizes, and if the lost labour effect is different among permanent and seasonal migrants.

Our results reveal that losing productive members induced a substantial loss in crop income, probably due to labour market imperfections and a strong reliance on family labour. However, the negative lost labour effect was partially compensated by obtained remittances. This indicates that rural households benefited from remittances, which relieve liquidity and insurance constraints and stimulate crop production through higher productivity.

The positive impact of remittances was not homogeneous across farmers with different land size. The marginal impact of remittances on crop income decreased for larger farmers. This may be associated with the fact that these do not face binding liquidity constraints in crop production and have low agricultural productivity. In general, the profitability of cropping is low and investment opportunities are limited, as the substantial underutilisation of owned land by large farmers suggests.

Finally, we have found that only permanent migrants had a significant negative effect on crop income. Taking into account that half of existing migrants from Kyrgyzstan work abroad on seasonal basis, this is an important finding. However, we are not sure whether the absence of a negative effect from seasonal migrants is driven by their mode of migration when they return home or by fact that few seasonal migrants were employed in agriculture before their departure.

In total, the net effect of migration on crop production is different for farms with different land size and across households with permanent and seasonal migrants. The negative impact of lost labour from permanent migrants seems to outweigh the positive impact of remittances for all types of rural farms and thus permanent migrants decrease crop income. At the same time, the net effect of seasonal migration seems to be positive for all but largest farms and thus seasonal migration stimulates crop production. The positive impact of remittances on small farms' productivity indicates the importance of establishing supporting institutions suitable for households with small size of land, which may also slow down permanent labour migration and as a result its negative impact on local crop 
production. Stimulating temporary migration with subsequent returns offers another alternative to diminish the negative effects of migration on local crop income. Finally, since international labour migration is a relatively new phenomenon in the current form, new studies are needed to see the more longterm effects of migrant and remittances on local communities.

Our conclusions and policy recommendations would have been completely different had we ignored the heterogeneity between households and types of migration. We would have missed the fact that, contrasting permanent migration, seasonal migration does not lower crop income. Also, we would not have found evidence of a need for access to financial institutions for especially small farm households. This implies that future studies on the impact of migration on sending communities should account for such potentially heterogeneous effects. 


\subsection{ANNEX}

Table A6.1. First stage equations from the recursive system of OLS equations for first and second specifications ( $\mathrm{N}=1836)$

\begin{tabular}{|c|c|c|c|c|c|}
\hline & \multicolumn{2}{|c|}{ I specification } & \multicolumn{3}{|c|}{ II specification } \\
\hline & $\begin{array}{l}\text { Total } \\
\text { remittance } \\
\mathrm{s}\end{array}$ & $\begin{array}{c}\text { Total } \\
\text { number of } \\
\text { migrants }\end{array}$ & $\begin{array}{c}\text { Total } \\
\text { remittance } \\
\mathrm{s} \\
\end{array}$ & $\begin{array}{l}\text { Total } \\
\text { remittance } \\
\mathrm{s}^{*} \text { land size }\end{array}$ & $\begin{array}{c}\text { Total } \\
\text { number of } \\
\text { migrants }\end{array}$ \\
\hline Mean norm to remit, som & $\begin{array}{c}0.918^{* * *} \\
{[0.214]}\end{array}$ & & $\begin{array}{l}1.138^{* * *} \\
{[0.257]}\end{array}$ & & \\
\hline Total number of migrants & $\begin{array}{l}-3876 \\
{[16401]}\end{array}$ & & $\begin{array}{l}-11345 \\
{[17365]}\end{array}$ & $\begin{array}{l}-40453 \\
{[46359]}\end{array}$ & \\
\hline Proxy for migration network & & $\begin{array}{l}0.787^{* * *} \\
{[0.269]}\end{array}$ & & & $\begin{array}{c}0.863^{* * *} \\
{[0.216]}\end{array}$ \\
\hline Mean norm to remit*land size & & & & $\begin{array}{c}1.881^{*} \\
{[0.978]}\end{array}$ & \\
\hline $\begin{array}{l}\text { Proxy for seasonal migration } \\
\text { network }\end{array}$ & & & & & \\
\hline $\begin{array}{l}\text { Proxy for permanent migration } \\
\text { network } \\
\text { Number of seasonal migrants }\end{array}$ & & & & & \\
\hline Number of permanent migrants & & & & & \\
\hline Household size & $\begin{array}{l}2767^{* *} \\
{[1408]}\end{array}$ & $\begin{array}{l}0.0817^{* * *} \\
{[0.0100]}\end{array}$ & $\begin{array}{l}3311^{* *} \\
{[1483]}\end{array}$ & $\begin{array}{l}5971^{*} \\
{[3416]}\end{array}$ & $\begin{array}{l}0.0811^{* * *} \\
{[0.00995]}\end{array}$ \\
\hline $\begin{array}{l}\text { Share of male adults in the } \\
\text { household size }\end{array}$ & $\begin{array}{l}15695^{*} \\
{[9497]}\end{array}$ & $\begin{array}{l}0.478^{* * *} \\
{[0.0729]}\end{array}$ & $\begin{array}{l}19309 * \\
{[10068]}\end{array}$ & $\begin{array}{l}31315 \\
{[20888]}\end{array}$ & $\begin{array}{l}0.481^{* * *} \\
{[0.0729]}\end{array}$ \\
\hline $\begin{array}{l}\text { Share of adults with higher } \\
\text { education in the household size }\end{array}$ & $\begin{array}{l}16949^{*} \\
{[9859]}\end{array}$ & $\begin{array}{c}0.247^{*} \\
{[0.134]}\end{array}$ & $\begin{array}{l}18615^{*} \\
{[10620]}\end{array}$ & $\begin{array}{c}27456 \\
{[21886]}\end{array}$ & $\begin{array}{c}0.247^{*} \\
{[0.134]}\end{array}$ \\
\hline Head of household age & $\begin{array}{c}265.3 \\
{[255.7]}\end{array}$ & $\begin{array}{c}0.00649 \\
{[0.00474]}\end{array}$ & $\begin{array}{c}341 \\
{[289.4]}\end{array}$ & $\begin{array}{c}452.2 \\
{[615.8]}\end{array}$ & $\begin{array}{c}0.00669 \\
{[0.00472]}\end{array}$ \\
\hline Head of household age squared & $\begin{array}{l}-2.716 \\
{[2.278]}\end{array}$ & $\begin{array}{l}-5.69 \mathrm{E}-05 \\
{[4.29 \mathrm{e}-05]}\end{array}$ & $\begin{array}{l}-3.373 \\
{[2.586]}\end{array}$ & $\begin{array}{l}-4.474 \\
{[5.628]}\end{array}$ & $\begin{array}{l}-5.84 \mathrm{E}-05 \\
{[4.28 \mathrm{e}-05]}\end{array}$ \\
\hline $\begin{array}{l}\text { Head of household gender, male } \\
\text { is the base }\end{array}$ & $\begin{array}{c}4865 \\
{[3171]}\end{array}$ & $\begin{array}{l}0.153^{* * *} \\
{[0.0391]}\end{array}$ & $\begin{array}{l}6070^{*} \\
{[3406]}\end{array}$ & $\begin{array}{l}11564 \\
{[7764]}\end{array}$ & $\begin{array}{l}0.152^{* * *} \\
{[0.0390]}\end{array}$ \\
\hline $\begin{array}{l}\text { Head of household has higher } \\
\text { education }\end{array}$ & $\begin{array}{l}-1168 \\
{[2586]}\end{array}$ & $\begin{array}{l}-0.0222 \\
{[0.0581]}\end{array}$ & $\begin{array}{l}-1176 \\
{[2920]}\end{array}$ & $\begin{array}{l}-945.7 \\
{[5076]}\end{array}$ & $\begin{array}{l}-0.0214 \\
{[0.0582]}\end{array}$ \\
\hline $\begin{array}{l}\text { Dummy, 2nd quartile, land per } \\
\text { capita }\end{array}$ & $\begin{array}{c}1100 \\
{[1530]}\end{array}$ & $\begin{array}{c}0.0411 \\
{[0.0301]}\end{array}$ & $\begin{array}{c}995 \\
{[1801]}\end{array}$ & $\begin{array}{l}-574.2 \\
{[2894]}\end{array}$ & $\begin{array}{c}0.0437 \\
{[0.0335]}\end{array}$ \\
\hline $\begin{array}{l}\text { Dummy, } 3 d \text { quartile, land per } \\
\text { capita }\end{array}$ & $\begin{array}{l}9634^{* * *} \\
{[3664]}\end{array}$ & $\begin{array}{l}0.158^{* * *} \\
{[0.0361]}\end{array}$ & $\begin{array}{c}10489^{* * *} \\
{[3969]}\end{array}$ & $\begin{array}{l}10180^{* *} \\
{[4774]}\end{array}$ & $\begin{array}{l}0.160^{* * *} \\
{[0.0373]}\end{array}$ \\
\hline $\begin{array}{l}\text { Dummy, 4th quartile, land per } \\
\text { capita }\end{array}$ & $\begin{array}{l}10790^{* *} \\
{[5118]}\end{array}$ & $\begin{array}{l}0.255^{* * *} \\
{[0.0473]}\end{array}$ & $\begin{array}{l}11887^{* *} \\
{[5070]}\end{array}$ & $\begin{array}{l}20208^{* *} \\
{[9293]}\end{array}$ & $\begin{array}{l}0.237^{* * *} \\
{[0.0441]}\end{array}$ \\
\hline Dummy Kyrgyz & -5.734 & -0.022 & -52.65 & -811 & -0.022 \\
\hline
\end{tabular}




\begin{tabular}{|c|c|c|c|c|c|}
\hline & \multicolumn{2}{|c|}{ I specification } & \multicolumn{3}{|c|}{ II specification } \\
\hline & $\begin{array}{c}\text { Total } \\
\text { remittance } \\
\mathrm{s}\end{array}$ & $\begin{array}{c}\text { Total } \\
\text { number of } \\
\text { migrants }\end{array}$ & $\begin{array}{c}\text { Total } \\
\text { remittance } \\
\mathrm{s}\end{array}$ & $\begin{array}{l}\text { Total } \\
\text { remittance } \\
\mathrm{s}^{*} \text { land size }\end{array}$ & $\begin{array}{c}\text { Total } \\
\text { number of } \\
\text { migrants }\end{array}$ \\
\hline & [1421] & [0.0360] & [1638] & [3436] & [0.0357] \\
\hline Dummy Uzbek & $\begin{array}{l}-4314^{*} \\
{[2592]}\end{array}$ & $\begin{array}{l}-0.0536 \\
{[0.0577]}\end{array}$ & $\begin{array}{l}-4816^{*} \\
{[2913]}\end{array}$ & $\begin{array}{l}-6292 \\
{[4685]}\end{array}$ & $\begin{array}{l}-0.0549 \\
{[0.0576]}\end{array}$ \\
\hline $\begin{array}{l}\text { Mean hours of access to clean } \\
\text { water in summer at local level }\end{array}$ & $\begin{array}{l}209.6^{* *} \\
{[94.85]}\end{array}$ & $\begin{array}{c}0.00175 \\
{[0.00175]}\end{array}$ & $\begin{array}{c}183.5^{*} \\
{[104.8]}\end{array}$ & $\begin{array}{c}108.4 \\
{[191.6]}\end{array}$ & $\begin{array}{c}0.00178 \\
{[0.00174]}\end{array}$ \\
\hline $\begin{array}{l}\text { Minutes needed to get to the } \\
\text { closest road }\end{array}$ & $\begin{array}{c}65.7 \\
{[91.78]}\end{array}$ & $\begin{array}{l}-0.00319^{* *} \\
{[0.00138]}\end{array}$ & $\begin{array}{c}43.48 \\
{[100.2]}\end{array}$ & $\begin{array}{l}-38.09 \\
{[226.7]}\end{array}$ & $\begin{array}{r}-0.00316^{* *} \\
{[0.00138]}\end{array}$ \\
\hline
\end{tabular}

Notes: ${ }^{* * *} \mathrm{p}<0.01,{ }^{* *} \mathrm{p}<0.05,{ }^{*} \mathrm{p}<0.1$. Regional dummies are not reported. Robust standards errors are in parentheses.

Table A6.2. First stage equations from the recursive system of OLS equations for third specification $(\mathrm{N}=1836)$

\begin{tabular}{|c|c|c|c|c|}
\hline & \multicolumn{4}{|c|}{ III specification } \\
\hline & $\begin{array}{l}\text { Total } \\
\text { remittances }\end{array}$ & $\begin{array}{c}\text { Total } \\
\text { remittances }{ }^{*} 1 \\
\text { and size }\end{array}$ & $\begin{array}{l}\text { Number of } \\
1 \text { seasonal } \\
\text { migrants }\end{array}$ & $\begin{array}{c}\text { Number o } \\
\text { permanen } \\
\text { migrants }\end{array}$ \\
\hline Mean norm to remit, som & $\begin{array}{l}1.175^{* * *} \\
{[0.260]}\end{array}$ & & & \\
\hline Mean norm to remit*land size & & $\begin{array}{l}1.933^{* *} \\
{[0.982]}\end{array}$ & & \\
\hline $\begin{array}{l}\text { Proxy for seasonal migration } \\
\text { network }\end{array}$ & & & $\begin{array}{l}1.257^{* * *} \\
{[0.291]}\end{array}$ & $\begin{array}{c}-0.505^{* * *} \\
{[0.173]}\end{array}$ \\
\hline $\begin{array}{l}\text { Proxy for permanent migration } \\
\text { network }\end{array}$ & & & $\begin{array}{l}-0.308^{* *} \\
{[0.130]}\end{array}$ & $\begin{array}{l}1.189^{* * *} \\
{[0.235]}\end{array}$ \\
\hline Number of seasonal migrants & $\begin{array}{l}-15359 \\
{[21907]}\end{array}$ & $\begin{array}{l}-50358 \\
{[50639]}\end{array}$ & & \\
\hline Number of permanent migrants & $\begin{array}{c}-9446 \\
{[14690]}\end{array}$ & $\begin{array}{l}-34899 \\
{[36517]}\end{array}$ & & \\
\hline Household size & $\begin{array}{l}3361^{* *} \\
{[1453]}\end{array}$ & $\begin{array}{l}6035^{*} \\
{[3090]}\end{array}$ & $\begin{array}{l}0.0385^{* * *} \\
{[0.00777]}\end{array}$ & $\begin{array}{l}0.0421^{* * *} \\
{[0.00838]}\end{array}$ \\
\hline $\begin{array}{l}\text { Share of male adults in the } \\
\text { household size }\end{array}$ & $\begin{array}{l}19809^{*} \\
{[10253]}\end{array}$ & $\begin{array}{l}32368^{*} \\
{[19465]}\end{array}$ & $\begin{array}{l}0.255^{* * *} \\
{[0.0534]}\end{array}$ & $\begin{array}{l}0.225^{* * *} \\
{[0.0533]}\end{array}$ \\
\hline $\begin{array}{l}\text { Share of adults with higher } \\
\text { education in the household size }\end{array}$ & $\begin{array}{l}18276^{*} \\
{[10107]}\end{array}$ & $\begin{array}{c}26414 \\
{[20527]}\end{array}$ & $\begin{array}{c}0.029 \\
{[0.0869]}\end{array}$ & $\begin{array}{l}0.216^{*} \\
{[0.113]}\end{array}$ \\
\hline Head of household age & $\begin{array}{c}330.6 \\
{[284.3]}\end{array}$ & $\begin{array}{c}411.8 \\
{[564.7]}\end{array}$ & $\begin{array}{c}0.00158 \\
{[0.00320]}\end{array}$ & $\begin{array}{c}0.00504 \\
{[0.00318]}\end{array}$ \\
\hline Head of household age squared & $\begin{array}{l}-3.317 \\
{[2.559]}\end{array}$ & $\begin{array}{l}-4.219 \\
{[5.219]}\end{array}$ & $\begin{array}{l}-1.68 \mathrm{E}-05 \\
{[2.84 \mathrm{e}-05]}\end{array}$ & $\begin{array}{l}-4.10 \mathrm{E}-05 \\
{[2.88 \mathrm{e}-05]}\end{array}$ \\
\hline $\begin{array}{l}\text { Head of household gender, male is } \\
\text { the base }\end{array}$ & $\begin{array}{l}6191^{*} \\
{[3376]}\end{array}$ & $\begin{array}{l}11795 \\
{[7198]}\end{array}$ & $\begin{array}{l}0.0734^{* *} \\
{[0.0287]}\end{array}$ & $\begin{array}{l}0.0777^{* *} \\
{[0.0322]}\end{array}$ \\
\hline
\end{tabular}




\begin{tabular}{lcccc}
\hline & \multicolumn{4}{c}{ III specification } \\
\hline & $\begin{array}{c}\text { Total } \\
\text { remittances }\end{array}$ & $\begin{array}{c}\text { remittances*1 } \\
\text { and size }\end{array}$ & $\begin{array}{c}\text { Number of } \\
\text { seasonal } \\
\text { migrants }\end{array}$ & $\begin{array}{c}\text { Number of } \\
\text { permanent } \\
\text { migrants }\end{array}$ \\
\hline Head of household has higher & -1081 & -689.1 & 0.00856 & -0.0297 \\
education & {$[2933]$} & {$[5166]$} & {$[0.0405]$} & {$[0.0454]$} \\
Dummy, 2nd quartile, land per & 1174 & 5.439 & 0.0336 & 0.0134 \\
capita & {$[1962]$} & {$[3186]$} & {$[0.0244]$} & {$[0.0258]$} \\
Dummy, 3d quartile, land per & $11013^{* *}$ & $11585^{* *}$ & $0.104^{* * *}$ & $0.0631^{* *}$ \\
capita & {$[4399]$} & {$[5460]$} & {$[0.0265]$} & {$[0.0283]$} \\
Dummy, 4th quartile, land per & $12189^{* *}$ & $20542^{* *}$ & $0.111^{* * *}$ & $0.127^{* * *}$ \\
capita & {$[4967]$} & {$[8795]$} & {$[0.0315]$} & {$[0.0363]$} \\
Dummy Kyrgyz & -18.86 & -720.7 & -0.011 & -0.00936 \\
& {$[1681]$} & {$[3433]$} & {$[0.0235]$} & {$[0.0277]$} \\
Dummy Uzbek & $-4932^{*}$ & -6497 & -0.019 & -0.0399 \\
& {$[2948]$} & {$[4719]$} & {$[0.0392]$} & {$[0.0458]$} \\
Mean hours of access to clean water & $184.7^{*}$ & 122.1 & 0.000603 & 0.00129 \\
in summer at local level & {$[108.2]$} & {$[192.2]$} & {$[0.00114]$} & {$[0.00143]$} \\
Minutes needed to get to the closest & 42.92 & -37.54 & $-0.00186^{*}$ & -0.0014 \\
road & {$[101.0]$} & {$[215.2]$} & {$[0.00102]$} & {$[0.000984]$} \\
\hline Nota
\end{tabular}

Notes: ${ }^{* * *} \mathrm{p}<0.01,{ }^{* *} \mathrm{p}<0.05,{ }^{*} \mathrm{p}<0.1$. Regional dummies are not reported. Robust standards errors are in parentheses.

Table A6.3. Test for instruments used in 2SLS

\begin{tabular}{lccccc} 
& & & \multicolumn{3}{c}{ Specifications } \\
\cline { 3 - 5 } Endogenous variables & \multicolumn{2}{c}{ Tests } & I & II & III \\
\hline Total number of & Angrist-Pischke & $\mathrm{F}(1,1814)$ & 8.21 & 8.17 & \\
migrants & multivariate $\mathrm{F}$ & $\mathrm{Prob}>\mathrm{F}$ & 0.00 & 0.00 & \\
Number of seasonal & test of excluded & $\mathrm{F}(1,1814)$ & na & na & 7.77 \\
migrants & instruments: & Prob $>\mathrm{F}$ & na & na & 0.0053 \\
Number of permanent & & $\mathrm{F}(1,1814)$ & na & na & 9.79 \\
migrants & & Prob $>\mathrm{F}$ & na & na & 0.0018 \\
Total remittances & & $\mathrm{F}(1,1814)$ & 9.19 & 8.07 & 5.15 \\
& & Prob $>\mathrm{F}$ & 0.00 & 0.00 & 0.02 \\
Total remittances ${ }^{*}$ own & & $\mathrm{F}(1,1814)$ & na & 3.18 & 3.24 \\
land size & & Prob $>\mathrm{F}$ & na & 0.0745 & 0.0718 \\
\hline Total number of & $\mathrm{F}$ test of excluded & $\mathrm{F}(\mathrm{k}, 1814)$ & 11.38 & 8.12 & na \\
migrants & instruments: & Prob $>\mathrm{F}$ & 0.00 & 0.00 & na \\
Number of seasonal & & $\mathrm{F}(\mathrm{k}, 1814)$ & na & na & 10.26 \\
migrants & & Prob $>\mathrm{F}$ & na & na & 0.00 \\
Number of permanent & & $\mathrm{F}(\mathrm{k}, 1814)$ & na & na & 10.79 \\
migrants & & Prob $>\mathrm{F}$ & na & na & 0.00 \\
Total remittances & $\mathrm{F}(\mathrm{k}, 1814)$ & 12.03 & 8.92 & 7.14 \\
& & Prob $>\mathrm{F}$ & 0.00 & 0.00 & 0.00
\end{tabular}




\begin{tabular}{|c|c|c|c|c|}
\hline \multirow[b]{2}{*}{ Endogenous variables } & & \multicolumn{3}{|c|}{ Specifications } \\
\hline & & I & II & III \\
\hline \multirow{2}{*}{$\begin{array}{l}\text { Total remittances*own } \\
\text { land size }\end{array}$} & $\mathrm{F}(\mathrm{k}, 1814)$ & na & 7.42 & 6.43 \\
\hline & Prob $>$ F & na & 0.00 & 0.00 \\
\hline \multirow[t]{2}{*}{ Underidentification test } & $\begin{array}{l}\text { Kleibergen- } \\
\text { Paap rk LM } \\
\text { statistic }\end{array}$ & 13.416 & 13.197 & 8.336 \\
\hline & $\begin{array}{l}\text { Chi-sq(1) P- } \\
\text { val }\end{array}$ & 0.00 & 0.00 & 0.00 \\
\hline \multirow{5}{*}{ Stock-Yogo weak ID test critical values: } & $\begin{array}{l}\text { Kleibergen- } \\
\text { Paap rk } \\
\text { Wald F } \\
\text { statistic }\end{array}$ & 7.432 & 4.897 & 2.136 \\
\hline & $\begin{array}{l}10 \% \\
\text { maximal IV } \\
\text { size }\end{array}$ & 7.03 & na & na \\
\hline & $\begin{array}{l}15 \% \\
\text { maximal IV } \\
\text { size }\end{array}$ & 4.58 & na & na \\
\hline & $\begin{array}{l}20 \% \\
\text { maximal IV } \\
\text { size }\end{array}$ & 3.95 & na & na \\
\hline & $\begin{array}{l}25 \% \\
\text { maximal IV } \\
\text { size }\end{array}$ & 3.63 & na & na \\
\hline
\end{tabular}

Source: authors' calculation.

Notes: numbers of migrants, remittances, and remittances*land are instrumented using share of households with migrants at the community level, the community level norm for remittances and the interaction between land and community norm for remittances. $\mathrm{K}$ is the number of endogenous variables.

Table A6.4. Description of variables

\begin{tabular}{ll}
\hline \multicolumn{1}{c}{ Name } & \multicolumn{1}{c}{ Description } \\
\hline Crop income & $\begin{array}{l}\text { Crop income is obtained as the difference between the total } \\
\text { market value of crops (by crop type) and expenditures on } \\
\text { their cultivation (salary, seeds, fertilisers, rent so forth). } \\
\text { The income from livestock is calculated as the difference } \\
\text { between the total value of livestock products and HH } \\
\text { expenditures on their production. Livestock products are } \\
\text { measured on the basis of annual change in the market prices } \\
\text { for livestock and poultry, market value of sold and } \\
\text { slaughtered livestock as well as the income from secondary } \\
\text { livestock products (milk, eggs, honey, wool etc.) excluding the } \\
\text { investments in livestock during 2006. } \\
\text { Nonfarm income includes self-employment and wage income }\end{array}$ \\
\hline
\end{tabular}




\begin{tabular}{|c|c|}
\hline Name & Description \\
\hline & in all sectors, except agriculture. \\
\hline Total number of migrants & $\begin{array}{l}\text { Total number of permanent and seasonal migrants, members } \\
\text { of the household. }\end{array}$ \\
\hline Total remittances & $\begin{array}{l}\text { Total remittances in cash and in kind household obtained } \\
\text { from migrants - household members in 2006, som. }\end{array}$ \\
\hline $\begin{array}{l}\text { Total remittances*own land } \\
\text { size }\end{array}$ & $\begin{array}{l}\text { Interaction of total amount of remittances and the size of } \\
\text { owned land. }\end{array}$ \\
\hline $\begin{array}{l}\text { A proxy for local norm to } \\
\text { remit, som }\end{array}$ & $\begin{array}{l}\text { Mean value of remittances per migrant estimated at the } \\
\text { community level, omitting observed household. }\end{array}$ \\
\hline $\begin{array}{l}\text { Mean norm to remit*land } \\
\text { size }\end{array}$ & Interaction of norm to remit and the size of owned land. \\
\hline Migration network, 2005 & $\begin{array}{l}\text { Proxy to migration network, measured as a share of } \\
\text { households with seasonal or permanent migrants left before } \\
2006 \text { to the total number of rural households at the } \\
\text { community level, omitting observed household. }\end{array}$ \\
\hline $\begin{array}{l}\text { Seasonal migration network, } \\
2005\end{array}$ & $\begin{array}{l}\text { Proxy to seasonal migration network, measured as a share of } \\
\text { households with seasonal migrants left before } 2006 \text { to the total } \\
\text { number of rural households at the community level, omitting } \\
\text { observed household. }\end{array}$ \\
\hline $\begin{array}{l}\text { Permanent migration } \\
\text { network, } 2005\end{array}$ & $\begin{array}{l}\text { Proxy to seasonal migration network, measured as a share of } \\
\text { households with permanent migrants left before } 2006 \text { to the } \\
\text { total number of rural households at the community level, } \\
\text { omitting observed household. }\end{array}$ \\
\hline $\begin{array}{l}\text { Number of seasonal } \\
\text { migrants }\end{array}$ & Number of seasonal migrants household members. \\
\hline $\begin{array}{l}\text { Number of permanent } \\
\text { migrants }\end{array}$ & Number of permanent migrants household members. \\
\hline HH size & Size of the household. \\
\hline Share of male adults & Share of male adults in the household. \\
\hline $\begin{array}{l}\text { Share of adults with higher } \\
\text { education }\end{array}$ & Share of adults with higher education in the household. \\
\hline $\mathrm{HH}$ age & Age of the head of household. \\
\hline $\mathrm{HH}$ gender, male is the base & Gender of the head of household, 1 is male. \\
\hline $\mathrm{HH}$ has higher education & Dummy if the head of household has higher education. \\
\hline Dummy Kyrgyz & Dummy if the head of household is Kyrgyz. \\
\hline Dummy Uzbek & Dummy if the head of household is Uzbek. \\
\hline $\begin{array}{l}\text { Mean hours of access to } \\
\text { clean water in summer at } \\
\text { local level }\end{array}$ & $\begin{array}{l}\text { Mean time of access to clean water during the day, calculated } \\
\text { at the local level, hours. }\end{array}$ \\
\hline $\begin{array}{l}\text { Minutes needed to get to the } \\
\text { closest road }\end{array}$ & $\begin{array}{l}\text { Mean time needed to get to the closest road, calculated at the } \\
\text { local level, minutes. }\end{array}$ \\
\hline Size of own land & The size of owned usable land, ha. \\
\hline
\end{tabular}


Table A6.5. Results from recursive system of OLS equations for total earned income, first specification $(\mathrm{N}=\mathbf{1 8 3 6})$

\begin{tabular}{|c|c|}
\hline & $\begin{array}{c}\text { Total earned } \\
\text { income }\end{array}$ \\
\hline \multirow[t]{2}{*}{ Number of migrants } & $-29930^{*}$ \\
\hline & [16778] \\
\hline \multirow{2}{*}{ Total remittances } & -0.133 \\
\hline & [0.138] \\
\hline \multirow[t]{2}{*}{ HH size } & $6407^{* * *}$ \\
\hline & [1021] \\
\hline \multirow[t]{2}{*}{ Share of male adults } & $24294^{* *}$ \\
\hline & [9536] \\
\hline \multirow[t]{2}{*}{ Share of adults with higher education } & $61671^{* * *}$ \\
\hline & [11602] \\
\hline \multirow[t]{2}{*}{$\mathrm{HH}$ age } & $842.1^{* *}$ \\
\hline & {$[368.1]$} \\
\hline \multirow[t]{2}{*}{$\mathrm{HH}$ age squared } & $-7.487^{* *}$ \\
\hline & [3.420] \\
\hline \multirow{2}{*}{$\mathrm{HH}$ gender, male is the base } & -4392 \\
\hline & [3288] \\
\hline \multirow[t]{2}{*}{ HH has higher education } & -780.5 \\
\hline & [3830] \\
\hline \multirow[t]{2}{*}{ Size of own land } & $13386^{* * *}$ \\
\hline & [3653] \\
\hline \multirow[t]{2}{*}{ Size of own land squared } & -39.76 \\
\hline & [359.6] \\
\hline \multirow[t]{2}{*}{ Dummy Kyrgyz } & $-8535^{* *}$ \\
\hline & [3849] \\
\hline \multirow[t]{2}{*}{ Dummy Uzbek } & $-11092^{* *}$ \\
\hline & [4364] \\
\hline \multirow{2}{*}{$\begin{array}{l}\text { Mean hours of access to clean water in } \\
\text { summer at local level }\end{array}$} & $314.2^{* *}$ \\
\hline & [124.0] \\
\hline Minutes needed to get to the closest & -172.6 \\
\hline road & [120.0] \\
\hline Observations & 1836 \\
\hline
\end{tabular}

Notes: ${ }^{* * *} \mathrm{p}<0.01,{ }^{* *} \mathrm{p}<0.05,{ }^{*} \mathrm{p}<0.1$. Results for regional dummies are not reported. Robust standards errors are in parentheses. Numbers of migrants and remittances are instrumented using the share of households with migrants at the community level and community norm for remittances. 
7. CONCLUSION 


\subsection{SYNTHESIS OF MAIN FINDINGS}

This dissertation addresses a number of issues related to the determinants and effects of local and international alternatives to agricultural employment in the rural areas of the Kyrgyz Republic. The study contributes both to the academic and policy debate by addressing several research objectives, providing new empirical evidence and distinguishing between different types of local nonfarm activities and international migration. In order to avoid repetition, we do not present conclusions from individual chapters, but rather focus on a synthesis of the main findings.

Empirical results demonstrate that in recent years both local nonfarm activities and international migration have played an important role in the rural areas of the Kyrgyz Republic in the context of a stagnating small-scale agricultural sector constrained by numerous market imperfections. Commercial RNFE is found to be most developed and important in areas with scarce land resources of poor quality, indicating a "push" scenario where rural residents have to supplement an insufficient level of agricultural income. The "push" scenario can be also related to the low commercialisation and subsistence orientation of the Kyrgyz agriculture, which is not capable to stimulate development of a buoyant nonfarm economy and to provide an adequate and stable amount of income.

In line with the "push" factors, nonfarm income is found to play a more important role in the total income of poor rural individuals confirming that barriers to access the RNFE are not substantial. Nevertheless, the lack of education, credit constraints and inadequate infrastructure limit the ability of the poor to move towards more remunerative nonfarm activities. Access to infrastructure and better education are often found to be positively associated with participation and income from the RNFE (Davis et al., 2007).

Our finding of an inverse relationship between land and nonfarm activities is consistent with empirical evidence from some Latin American countries where the share of nonfarm income decreases with land size and poor agricultural zones tend to have more households relying on nonfarm activities (Reardon et al., 2001). As Adams points out (2002), this scenario often happens in land-scarce and labourrich countries where inadequate access to land "pushes" poor people out of agriculture.

In contrast to local nonfarm activities, high transportation and settlement costs make international migration a not easily accessible option for rural households with small land holdings, excluding those in need for additional income to complement limited agricultural base. This implies that the current stage local nonfarm activities and international migration do not overlap much with each other and provide income-generating opportunities to households with different levels of assets. However, other empirical findings make the interrelationships between two activities more complicated. 
In particular, we show that better education is the key determinant of both permanent migration and nonfarm wage employment, but that it does not play any role in the choice between participation in seasonal migration, local nonfarm self-employment and working at home in the agricultural sector. Therefore, the expected returns to education are higher for permanent migrants who undertake formal employment in comparison to short-term low-skilled jobs of seasonal migrants. Accordingly, the loss of better educated permanent migrants can potentially have a negative impact on formal employment in nonfarm activities, while the loss of seasonal migrants is not likely to generate a brain drain effect and may be less harmful for local development.

The obtained findings contribute to the limited empirical evidence on the determinants of seasonal and permanent migration (Görlich \& Trebesch, 2006; Joarder \& Hasanuzzaman, 2008; Pinger, 2010) and stress the different roles better education plays in participation in temporary and permanent moves. Inclusion of local and abroad income generating activities in a single empirical model helps to disentangle the role of the same factors for particular nonfarm alternatives to agriculture. For instance, the importance of higher education for both permanent migration and wage nonfarm employment may contribute both to the human capital theory and the brain drain discussion (Martin \& Taylor, 2001; Dustmann \& Weiss, 2007; Faini, 2007).

In addition to being an important alternative to agriculture, international migration and associated remittances have a complex impact on agricultural productivity and crop income. In line with the New Economics of Labour Migration, remittances are found to stimulate agricultural productivity and as a result crop income, but the positive effect only holds for seasonal migration because this does not generate significant lost labour effects. At the same time, the positive impact of remittances on crop income is outweighed by significant negative lost labour effect for permanent migrants. This makes net effect from permanent migration on crop income negative.

Importantly the positive impact of remittances on crop income is only found for small and middle size farms, which probably face stronger liquidity constraints and are more productive than large farms. Overall, one should not expect permanent migration to revive agricultural growth through higher productivity, but this potential may well exist for seasonal migration in the long run. Besides their policy relevance and contribution to the discussion of the constraints small farmers face (Lerman \& Sedik, 2009b), the identified heterogeneous effects of migration and remittances on crop income provide new empirical support for the propositions of the New Economics of Labour Migration (Lucas, 1987; Taylor \& Wyatt, 1996; Taylor et al., 2003; de Brauw, 2010). Ignoring heterogeneity between households and types of migration may result in misleading conclusions and should be taken into account in future empirical studies. 


\subsection{POLICY RECOMMENDATIONS AND FUTURE STEPS}

Empirical research reveals that the RNFE in the Kyrgyz Republic has predominant "push" nature and nonfarm activities are accessible to the poor. Under these circumstances, besides stimulating agricultural development per se through establishing working institutions designed for small family farming, it is important to focus on general factors identified to affect the profitability and expansion of the current rural nonfarm activities, especially in areas where the capacity of agriculture is constrained by the natural environment. Investment in infrastructure, access to financial resources, skill building and enhancing of human capital along with local engines of growth can help to create such a favourable environment and should be taken into account while designing and implementing rural policies in the Kyrgyz Republic. Specific policies to increase access of the poor to profitable nonfarm activities are only useful in the few areas with very favourable agricultural circumstances or with resorts.

The importance of local nonfarm activities should also be taken into account by policy makers because international migration seems to have substantial entry barriers and seems to be non-accessible for those with small size of land at least in the time span covered by this study. Moreover, permanent migrants are often better educated which can lead to a brain drain effect. Therefore, stimulation of temporary migration with regular returns home, especially for those with better education, has a potential to lessen the negative impact of migration on local development.

The identified positive role of remittances on local agricultural income should not be overestimated even though remittances help small farmers to overcome existing liquidity and insurance constraints. Increases in productivity due to remittances inflow can raise crop income only in case of seasonal migration. They are still much less than needed to compensate for substantial lost labour effect in case of permanent migration. Furthermore, remittances do not have any positive impact and even decrease crop income of large farms. These signal that the agricultural sector continues to be subsistence oriented rather than a market oriented sector and its prospects in the context of continuing labour migration are uncertain at best. Still the creation of institutional environment conducive to serving individualized small farming should be at the top of the agenda of policy makers and the donor community. This may also slow down permanent labour migration and as a result reduce its negative impact on local crop production. As already mentioned, another potential option to enhance developmental effects of migration is to motivate temporary migration with subsequent return.

The present work reveals some options for future research which could address limitations of this dissertation and expand the current analysis. Lack of the panel data limits our ability to control for unobservable factors in the determinants of nonfarm income which may bias the results obtained. Unfortunately, there are 
no longitudinal data on Kyrgyzstan ${ }^{47}$, but even longitudinal data can not necessarily solve the problem since endogenous variables, such as education are often almost invariant. In such circumstances, the search for suitable quasi-natural experiments is an option.

It will be interesting to analyse and compare development of the RNFE in other poor Central Asian countries where land reform is far from accomplished and the governments intervene in farming decisions (decisions to grow cotton in Tajikistan and Uzbekistan). In contrast to Kyrgyzstan, obligatory cotton growing can "push" rural residents to engage in the RNFE due inability to diversify agricultural production and fully benefit from agricultural resources even if they have enough land resources of a good quality. The proposed analysis can be relevant for these countries in case of abolition of the state control over land and farming decisions.

A next step would be to also test whether nonfarm activities can smooth seasonal volatility in food consumption among rural inhabitants since the RNFE is expected to smooth intra-year and inter year income flows (Ellis, 1998). This potential study could benefit from discriminating between different nonfarm activities which may have different levels of correlation with agriculture and consequently have different smoothing potentials. Finally, the current research on the impact of migration on crop income can be extended by focusing on the effects on local individual labour supply differentiating between females and males.

\footnotetext{
${ }^{47}$ Only in 2010 German Institute for Economic Research launched the project "Economic Transformation, Household Behaviour and Well-Being in Central Asia: The Case of Kyrgyzstan" with the aim to collect panel survey data in Kyrgyzstan. For further information, please visit the project's page: http://www.diw.de/sixcms/detail.php?id=diw_01.c.345525.en.
} 


\section{REFERENCES}

Abdulai, A. \& CroleRees, A. (2001). Determinants of income diversification amongst rural households in Southern Mali. Food Policy, 26 (4), 437-452.

Abella, M. (2006). Policies and best practices for management of temporary migration, International Symposium on International Migration and Development, United Nations Secretariat. Population Division.

Adams, R. (1993). The economic and demographic determinants of international migration in rural Egypt. The Journal of Development Studies, 30(1), 146167.

Adams, R. (2002). Nonfarm income, inequality and land in rural Egypt. Economic Development and Cultural Change, 50(2), 339-363.

Akramov, K \& Omuraliev, N. (2009). Institutional Change, Rural Services, and Agricultural Performance in Kyrgyzstan. International Food Policy Research Institute Discussion Paper, 00904.

Amuedo-Dorantes, C. \& Pozo, S. (2006). Migration, Remittances, and Male and Female Employment Patterns. American Economic Review, 96(2), 222-226.

Asian Development Bank (2008a). A study on international migrants' remittances in Central Asia and South Caucasus, Country Report on Remittances of International Migrants and Poverty in the Kyrgyz Republic.

Asian Development Bank (2008b). A study on international migrants' remittances in Central Asia and South Caucasus, Country Report on Remittances of International Migrants and the Financial Sector in the Kyrgyz Republic.

Asian Development Bank (2008c). A Study on International Migrants' Remittances in Central Asia and South Caucasus, Country Report on Remittances of International Migrants in Tajikistan.

Asian Development Bank, International Monetary Fund \& World Bank (2010). Joint Economic Assessment: Reconciliation, Recovery and Reconstruction. July 21.

Atamanov, A. \& Van den Berg, M. (2010). Rural non-farm activities in Central Asia: A regional analysis of magnitude, structure, evolution and drivers in the Kyrgyz Republic, Working paper №005. Maastricht University. Maastricht Graduate School of Governance. Forthcoming in Europe-Asia Studies. 
Barrett, C. \& Reardon, T. (2000). Assets, Activity and Income Diversification among African Agriculturists: Some Practical Issues, Working Paper Series № 14734. Cornell University.

Barrett, C., Reardon, T., \& Webb, P. (2001). Nonfarm Income Diversification and Household Livelihood Strategies in Rural Africa: Concepts, Dynamics, and Policy Implications. Food Policy, 26(4), 315-331.

Cappellari, L. \& Jenkins, S. (2003). Multivariate probit regression using simulated maximum likelihood. The Stata Journal, 3(3), 278-294.

Christensen, G. \& Pomfret, R. (2007). Distortions to Agricultural Incentives in the Kyrgyz Republic. Working paper 04.

Corral, L. \& Reardon, T. (2001). Rural Nonfarm Incomes in Nicaragua. World Development, 29(3), 427-442.

Cragg, J. (1971). Some Statistical Models for Limited Dependent Variables with Application to the Demand for Durable Goods. Econometrica, 39(5), 829844.

Cukrowski, J. Dabrowski, M., Gortat, R. \& Mogileski, R (2002). The Kyrgyz Republic: Developing New Capacities in a Post-Transition Country in: Browne, S. (eds.) (2002). UNDP.

Dall'Olio, A. (2008). Access to Financial Services, Joint Kyrgyz Government / World Bank / IMF Workshop "Coping with Short Term Risks and Vulnerabilities and Accelerating Long Term Growth", Bishkek, 25 June 2008.

Davis, B. \& Bezemer, J. (2003). Key Emerging and Conceptual Issues in the Development of the RNFE in Developing Countries and Transition Economies, Natural Resources Institute Report, 2755.

Davis, B., Stecklov, G. \& Winters, P. (2002). Domestic and international migration from rural Mexico: Disaggregating the effects of network structure and composition. Population Studies, 56(3), 291-309.

Davis, B., Winters, P., Carletto, G., Covarrubias, K., Quinones, E., Zezza, A., Stamoilis, K., Bonomi, G. \& DiGiuseppe, S. (2007). Rural Income Generating Activities: A Cross Country Comparison, ESA Working Paper, 07-16, May. The Food and Agriculture Organization of the United Nations.

Davis, B., Winters, P., Carletto, G., Covarrubias, K., Quinones, E., Zezza, A., Stamoilis, K., Bonomi, G. \& DiGiuseppe, S. (2010). A Cross Country Comparison of Rural Income Generating Activities. World Development, $38(1), 48-63$. 
De Brauw, A. (2010). Seasonal Migration and Agricultural Production in Vietnam. The Journal of Development Studies, 46(1), 114-139.

De Haan, A. (1999). Livelihood and poverty: The role of migration - a critical review of migration literature. The Journal of Development Studies, 36(2), 147.

De Haas, H. (2010). Migration and Development: A Theoretical Perspective. International Migration Review, 44(1), 227-264.

De Janvry, A. \& Sadoulet, E. (1996). Household Modeling for the Design of Poverty Alleviation Strategies, Paper submitted for presentation at the European Association of Agricultural Economists VIII Congress, Edinburgh, Scotland, September 3-7, 1996.

Delehanty, J. \& Rasmussen, K. (1996). Agricultural Structure in Bloch, P., Delehanty, J. \& Roth, M. (eds). Land Tenure Center. University of Wisconsin-Madison.

Dustmann, C. \& Weiss, Y. (2007). Return migration: Theory and empirical evidence, CReAM Discussion Paper Series №02. Centre for Research and Analysis of Migration.

Ellis, F. (2004). Occupational Diversification in Developing Countries and Implications for Agricultural Policy, Programme of Advisory and Support Services to DFID (PASS). Project № WB0207.

Ellis, F. \& Allison, E. (2004). Livelihood Diversification and Natural Resource Access. Working paper 9. Overseas Development Group. University of East Anglia

Ellis. F. (1998). Household Strategies and Rural Livelihood Diversification. The Journal of Development Studies, 35(1), 1-35.

Erzan, R. (2008). Circular migration: Economic aspects, CARIM Analytic and Synthetic Notes 31. Robert Shuman Center for Advanced Studies, San Domenico di Fiesole, European University Institute.

Escobal, J. (2001). The Determinants of Nonfarm Income Diversification in Rural Peru. World Development, 29(3), 497-508.

European Bank for Reconstruction and Development. http://www.ebrd.com/pages/research/economics/data/macro.shtml\#ti

Faini, R. (2007). Remittances and the Brain Drain: Do More Skilled Migrants Remit More? The World Bank Economic Review, 21(2), 177-191.

Food Agricultural Organization (2009). FAO Statistical Yearbook 2009. 
Foster, A. \& Rosenzweig, M. (2004). Agricultural Productivity Growth. Rural Economic Diversity, and Economic Reforms: India, 1970-2000. Economic Development and Cultural Change, 52(3), 509-542.

Freese, J. \& Long, J. (2001). Regression Models for Categorical Dependent Variables Using STATA, Stata Corporation.

Global Commission for Migration (2005). Migration in an interconnected world: New directions for action, Report of the Global Commission for Migration. SRO-Kundig.

Görlich, D. \& Trebesch, C. (2008). Seasonal Migration and Networks-Evidence on Moldova's Labour Exodus. Review of World Economics, 144 (1), 107-133.

Greene, W. (2000). Econometric Analysis, 4th ed. NewJersey: Prentice-Hall.

Guadagni, M. \& Fileccia, T. (2009). The Kyrgyz Republic Farm Mechanization and Agricultural Productivity, Country Highlights Paper. FAO Investment Center.

Haggblade, S. \& Hazell, P. (1989). Agricultural Technology and Farm-Nonfarm Growth Linkages. Agricultural Economics, 3(4), 345-364.

Haggblade, S. Hazell, P. \& Dorosh, P. (2007). Sectoral growth linkages between agriculture and the rural nonfarm economy. Chapter 7 in Haggblade, S., Hazell, P. \& Reardon, T. (eds.). Transforming the Rural Nonfarm Economy. Baltimore: Johns Hopkins University Press.

Haggblade, S., Hazell, P. \& Reardon, T (2002). Strategies for Stimulating PovertyAlleviating Growth in the Rural Nonfarm Economy in Developing Countries. EPTD Discussion Paper № 92. International Food Policy Research Institute. The World Bank.

Hausman, J. \& McFadden, D. (1984). Specification Tests for the Multinomial Logit Model. Econometric Society, 52(5), 1219-1240.

Hugo, G. (2009). Circular migration and development: an Asia-Pacific perspective", In: Hofirek, O. \& Klvanova, R. Boundaries in motion. Rethinking Contemporary Migration Events. Vyd. 1. Brno: Centrum pro demokracii a kulturu.

Humphreys, B., Lee, Y. \& Soebbing, B. (2009). Consumer Behaviour in Lotto Markets: The Double Hurdle Approach and Zeros in Gambling Survey Data. Working Paper No. 2009-27. University of Alberta.

International Finance Corporation and the World Bank. Doing Business. http://www.doingbusiness.org/ 
International Labour Organization (2010). Migrant remittances to Tajikistan: the Potential for savings, economic investment and existing financial products to attract remittances, Subregional Office for Eastern Europe and Central Asia. Moscow: ILO.

Isgut, A. (2004). Non-farm Income and Employment in Rural Honduras: Assessing the Role of Locational Factors. The Journal of Development Studies, 40(3), 59-86.

Islam, N. (1997). The Nonfarm Sector and Rural Development: the Review of Issues and Evidence, International Food Policy Research Institute. Food, Agriculture and the Environment Discussion Papers, 22, August.

Joarder M. \& Hasanuzzaman, S. (2008). Migration decision from Bangladesh: permanent versus temporary. Asia Europe Journal, 6(3), 531-545

Jonasson, E. \& Helfand, S. (2010). How Important are Locational Characteristics for Rural Non-agricultural Employment? Lessons from Brazil. World Development, 38(5), 727-741.

Katchova, A. \& Mirande, M. (2004). Two-Step Econometric Estimation of Farm Characteristics Affecting Marketing Contract Decisions. American Journal of Agricultural Economics. 86(1), 88-102.

Kaufmann, D., Kraay, A. \& Mastruzzi, M. (2010). The Worldwide Governance Indicators. Methodology and Analytical Issues. Policy Research Working Paper №WPS5439. The World Bank.

Kothari, U. (2002). Migration and chronic poverty, Working Paper №16, Institute for Development Policy and Management, University of Manchester.

Lanjouw, J. \& Lanjouw, P. (2001). The Rural Non-farm Sector: Issues and Evidence from Developing Countries. Agricultural Economics, 26(1), 1-23.

Lay, J., M'Mukaria, G. \& Mahmoud, T. (2007). Boda Bodas Rule: Non-agricultural Activities and Their Inequality Implications in Western Kenya, Kiel Working Paper No. 1314. Kiel Institute for the World Economy.

Lerman, Z. \& Sedik, D. (2009a). Agricultural Recovery and Individual Land Tenure: Lessons from Central Asia, Policy Studies on Rural Transition, 2009-3. (The Regional Office for Europe and Central Asia of the Food and Agriculture Organization).

Lerman, Z. \& Sedik, D. (2009b). Agrarian Reform in Kyrgyzstan: Achievements and the Unfinished Agenda, Discussion Paper No.11.09. The Hebrew University of Jerusalem. 
Lerman, Z. (2007). Land Reform, Farm Structure, and Agricultural Performance in CIS Countries, Discussion Paper, 7.07, April. The Hebrew University of Jerusalem.

Lewis, A. (1954). Economic Development with Unlimited Supplies of Labor. The Manchester School of Economic and Social Studies, 22(May), 139-91.

Light, M. (2007). Agriculture in Kyrgyzstan: growth engine or safety net, Joint Kyrgyz Government / World Bank / IMF Workshop "Coping with short term risks and vulnerabilities and accelerating long term growth", Bishkek, 25 June 2008.

Lokshin, M. \& Glinskaya, E. (2008). The Effect of Male Migration for Work on Employment Patterns of Females in Nepal. World Bank Economic Review, Oxford University Press, 23(3), 481-507.

Lucas, R. (1987). Emigration to South Africa's Mines. The American Economic Review, 77(3), 313-330.

Maddock, N. (2009). Note on actions in rural development in Central Asia, Central Asia Cluster Meeting: Almaty 3-5 December 2009.

Mansoor, A. \& Quillin, B. (2006). Migration and remittances: Eastern Europe and the Former Soviet Union. Europe and Central Asia Region Edition. Washington: World Bank.

Martin, P. \& Taylor, E. (2001). Human Capital: Migration and Rural Population Change. Chapter 9 in Handbook of Agricultural Economics, 1(1), 457-511.

Massey, D. (1990). Social structure, household strategies, and the cumulative causation of migration. Population Index, 56(1), 3-26.

Massey, D., Arango, J. Hugo, G. Kouaouci, A., Pellegrino, A. \& Taylor, J. (1993). Theories of international migration: a review and appraisal. Population and Development Review, 19(3), 431-466.

Matshe, I. \& Young, T. (2004). Off-farm Labour Allocation Decisions in Small-scale Rural Households in Zimbabwe. Agricultural Economics, 30(3), 175-186.

Mazzucato, V. (2008). Simultaneity and Networks in Transnational Migration: Lessons Learned from an Simultaneous Matched-Sample Methodology In DeWind, J. \& Holdaway, J. (eds.) Migration and Development Within and Across Borders. Geneva: International Organization for Migration.

Mckenzie, D. \& Rapoport, H. (2007). Network effects and the dynamics of migration and inequality: Theory and evidence from Mexico. Journal of Development Economics, 84(1), 1-24, 
Mellor, J. (eds.) (1995). Agriculture on the Road to Industrialization, International Food Policy Research Institute. London, Johns Hopkins University Press.

Mendola, M. (2004). Migration and Technological Change in Rural Households: Complements or Substitutes. Journal of Development Economics, 85(1-2), 150-175.

Milanovic, B. (1998). Income, Inequality, and Poverty during the Transition from Planned to Market Economy. 17419. The World Bank.

Moffatt, P. (2005). Hurdle Models of Loan Default. Journal of the Operational Research Society, 56, 1063-1071.

Mogilevsky, R. \& Atamanov, A. (2008). Technical Assistance to CIS countries. CASE Network Studies and Analysis. № 369. Center for Social and Economic Research CASE. Warsaw.

Mogilevsky, R. \& Atamanov, A. (2009) Remittances and Their Impact on Macroeconomic Situation of and Financial Sector Development in the Kyrgyz Republic. In Kochendorfer-Lucius, G. \& Plescovic, B. (eds.). Spatial Disparities and Development Policy. The World Bank.

Mora, J. \& Taylor, E. (2005). Determinants of Migration, Destination, and Sector Choice: Disentangling Individual, Household, and Community Effects. In Ozden, C. \& Schiff, M. (eds.), International Migration, Remittances, and the Brain Drain. New York: Palgrave Macmillan.

Mudahar, M. (1998). Kyrgyz Republic Strategy for Rural Growth and Poverty Alleviation. World Bank Discussion Paper 394. The World Bank.

M-Vector (2007). Study of Readiness and Motives of Rural Population to Join Cooperatives. Sociological Survey.

National Bank of the Kyrgyz Republic (2010). Development trends of the banking system. First half of 2010 (17). Bishkek.

National Bank of the Kyrgyz Republic. www.nbkr.kg

National Statistical Committee of the Kyrgyz Republic. www.stat.kg

Newland, K. (2009). Circular migration and human development, Human Development Research Paper №42. United Nations Development Programme.

OECD, ACTED \& European Commission (2009). Impact of the global financial crisis on labour migration from Kyrgyzstan to Russia: Qualitative overview and quantitative survey. 
Organisation of Economic Co-operation and Development (2006). The New Rural Paradigm: Policies and Governance. OECD Rural Policy Reviews.

Pinger, P. (2010). Come Back or Stay? Spend Here or There? Return and Remittances: The Case of Moldova. International Migration, 48(5), 142-173.

Powell, J. (1984). Least absolute deviations estimation for the censored regression model. Journal of Econometrics, 25(3), 303-325.

Ranis, G. \& Fei, J. C. (1961). A Theory of Economic Development. The American Economic Review, 51(4), 533-565.

Reardon, T. (1997). Using Evidence of Household Income Diversification to Inform Study of the Rural Non-Farm Labor Market in Africa. World Development, 25(5), 735-747.

Reardon, T., Berdegue, J. \& Escobar, G. (2001). Rural nonfarm employment and incomes in Latin America: Overview and policy implications. World Development, 29(3), 395-409.

Reardon, T., Berdegue, J., Barret, C. \& Stamoilis, K. (2006). Household Income Diversification into Rural Nonfarm Activities Chapter 8 in Haggblade, S., Hazell, P. \& Reardon, T. (eds.). Transforming the Rural Nonfarm Economy. Baltimore: Johns Hopkins University Press.

Roodman, D. (2009). Estimating Fully Observed Recursive Mixed-Process Models with cmp. CGD Working Paper 168. Washington, D.C.: Center for Global Development.

Rozelle, S. \& Swinnen, J. (2004). Success and Failure of Reform: Insight from the Transition of Agriculture. Journal of Economic Literature, XLII, 404-456.

Saith, A. (1992). The Rural Non-farm Economy: Processes and Policies, Geneva, International Labour Office.

Schmidt, M. \& Sagynbekova, L. (2008). Migration past and present: changing patterns in Kyrgyzstan. Central Asian Survey, 27(2), 111-127.

Scoones, I. (1998). Sustainable rural livelihoods: a framework for analysis, IDS Working Paper №72.

Shi, H., Heerink, N. \& Qu, F. (2007). Choices between different off-farm employment sub-categories: An empirical analysis for Jiangxi Province, China. China Economic Review, 18(4), 438-455.

Shonchoy, A. (2008). Seasonal migration and the effectiveness of micro-credit in the lean period: Evidence from Bangladesh, The University of New South Wales. 
Singh, I., Squire, L. \& Strauss, J. (1986). A Survey of Agricultural Household Models: Recent Findings and Policy Implications, World Bank Economic Review, 1, 149-179.

Small, K. \&. Hsiao C. (1985). Multinomial logit specification tests. International Economic Review, 26(3), 619-27

Spoor, M. (2008). Land, Markets and Rural Poverty in the CIS-7. In: M. Spoor (eds.), The Political Economy of Rural Livelihoods in Transition Countries. Lands, Peasants and Rural Poverty in Transition. Routledge ISS Studies in Rural Livelihoods.

Stark, O. (1991). The Migration of Labor. Massachusetts: Blackwell Publishers.

Stark, O. \& Bloom, B. (1985). The New Economics of Labor Migration. The American Economic Review, 75(2), 173-178.

Stark, O. \& Fan, S. (2007). The Analytics of Seasonal Migration, Discussion Papers on Development Policy №113. The Center for Development Research, Bonn.

Taylor E. \& Adelman, I. (2003). Agricultural Household Models: Genesis, Evolution, and Extensions. Review of Economics of the Household, 1(1), 3358.

Taylor, E. \& Wyatt, T. (1996). The Shadow Value of Migrant Remittances, Income and Inequality in a Household Farm Economy. The Journal of Development Studies, 32(6), 899-912.

Taylor, E. (1999). The New Economics of Labour Migration and the Role of Remittances in the Migration Process. International Migration, 37(1), 6388.

Taylor, E., Rozelle, S. \& de Brauw, A. (1999). Migration, Remittances, and Agricultural Productivity in China. American Economic Review, 89(2), 287291.

Taylor, E., Rozelle, S. \& de Brauw, A. (2003). Migration and Incomes in Source Communities: A New Economics of Migration Perspective from China. Economic Development and Cultural Change, 52(1), 75-101.

The National Bank of the Kyrgyz Republic. www.nbkr.kg

The National Bank of the Kyrgyz Republic (2009). Balance of Payments of the Kyrgyz Republic. Bishkek.

Todaro, M. (1969). A Model of Labor Migration and Urban Unemployment in Less Developed Countries. The American Economic Review, 59 (1), 138-148. 
United Nations Development Programme (2002). Human Development in Mountain Regions in the Kyrgyz Republic. National Human Development Report.

United States Agency for International Development (2008). Development of the Agricultural Land Market in Kyrgyzstan. The Analysis and Recommendations. (Bishkek).

Vadean, F. \& Piracha, M. (2009). Determinants of Return and Secular Migration in Albania, University of Kent and IZA.

Waddington, H. \& Sabates-Wheeler, R. (2003). How does poverty affect migration choice? A review of literature Working Paper №T3. Institute of Development Studies, Sussex.

Wilhelm, M. (2008). Practitioners' corner. Practical considerations for choosing between Tobit and SCLS or CLAD estimators for censored regression models with an application to charitable giving. Oxford Bulletin of Economics and Statistics, 70(4), 559-582.

Woldenhanna, T. \& Oskam, A. (2001). Income Diversification and Entry Barriers: Evidence from the Tigray Region of Northern Ethiopia. Food Policy, 26(4), 351-365.

World Bank (1993). Kyrgyzstan: the Transition to a Market Economy. Washington.

World Bank (1998). Kyrgyz Republic Agricultural Policy Review Strategy of Rural Growth and Poverty Alleviation. Report 17734-KG. World Bank.

World Bank (1999). Kyrgyz Republic Private Sector Review in the Transitional Era. Report 18121-KG. World Bank.

World Bank (2004). Kyrgyz Republic Agricultural Policy Update Sustaining Propoor Rural Growth: Emerging Challenges for Government and Donors.

World Bank (2007). Kyrgyz Republic Poverty Assessment (In Two Volumes) Volume II: Labor Market Dimensions of Poverty. Report 40864-KG.

World Bank (2008). Kyrgyz Republic at a Glance. Development Economics LDB Database.

World Bank (2009). World Development Indicators. The World Bank Group.

Wouterse, F. \& Taylor, E. (2008). Migration and Income Diversification: Evidence from Burkina Faso. World Development, 36(4), 625-640.

Yunez-Naude, A. \& Taylor, E. (2001). The Determinants of Non-farm Activities and Incomes of Rural Households in Mexico, with Emphasis on Education. World Development, 29(3), 561-572. 


\section{SUMMARY IN DUTCH/SAMENVATTING}

\section{Rurale niet-agrarische werkgelegenheid en internationale migratie als alternatieven voor agrarische werkgelegenheid in Kirgizstan}

Dit proefschrift behandelt een aantal zaken gerelateerd aan de identificatie van de determinanten en effecten van lokale niet-agrarische activiteiten en internationale migratie als alternatieven voor agrarische werkgelegenheid. De studie is gebaseerd op het voorbeeld van Kirgizstan, een arm, vooral ruraal, Centraal Aziatisch land met een niveau van agrarische ontwikkeling dat niet genoeg is om de situatie op het platteland voldoende te verbeteren. Onvolledige werkgelegenheid in de landbouw en rurale armoede staan nog steeds op de agenda van beleidsmakers.

Het proefschrift bestaat uit vijf hoofdstukken naast een introductie en een conclusie. Het tweede hoofdstuk beschrijft de sociaaleconomische ontwikkeling van het land sinds de onafhankelijkheid en bediscussieert hoe die de landelijke niet-agrarische economie (LNAE) in Kirgizstan kan beïnvloeden. De focus op lokale en internationale alternatieven voor inkomen uit landbouw in landelijke gebieden van de Kirgizische republiek verbindt de verschillende hoofdstukken.

Het derde hoofdstuk verkent de ontwikkeling, structuur en determinanten van de LNAE in Kirgizstan op regionaal niveau na tien jaar hervormingen aan de hand van drie representatieve huishoudenquêtes uit de jaren 2003, 2005 en 2006. Aan de hand van verschillende indicatoren op landelijk en regionaal niveau behandelen we de grootte, samenstelling en ontwikkeling van de niet-agrarische sector met betrekking tot totale werkgelegenheid, inkomen, en arbeidsuren van de plattelandsbevolking. De ontwikkeling van de LNAE wordt besproken in de context van landbouwhervormingen en veranderingen in de institutionele structuur. Econometrisch onderzoek laat zien dat de commerciële LNAE het meest ontwikkeld en belangrijk was in gebieden met weinig en kwalitatief slecht land. Dit wijst op een "duw" scenario waarbij plattelandsbewoners een te laag landbouwinkomen moesten aanvullen. Het "duw" scenario kan ook gerelateerd zijn aan de beperkte commercialisering en de oriëntatie op zelfvoorziening van de Kirgizische landbouw, die niet in staat was om de ontwikkeling van een bloeiende niet-agrarische economie te simuleren of om voor voldoende, stabiel landbouwinkomen te zorgen. De sterke negatieve verbanden tussen de LNAE en de grootte en kwaliteit van land betekenen dat niet-agrarische activiteiten relatief goed toegankelijk zijn voor de armen, ook al genereren ze niet noodzakelijkerwijs hoge inkomsten.

Het vierde hoofdstuk focust op het identificeren van factoren die plattelandsbewoners hebben geholpen of beperkt bij hun deelname aan 
verschillende niet-agrarische activiteiten en het verdienen van niet-agrarisch inkomen op microniveau. Het is een logisch vervolg op het onderzoek gepresenteerd in hoofdstuk 3. De empirische analyse laat zien dat weinig hulpbronnen, onvoldoende landbouwinkomen en marktimperfecties ervoor gezorgd hebben dat individuen hun toevlucht zoeken tot niet-agrarische activiteiten om hun magere landbouwinkomen aan te vullen of om seizoensfluctuaties in kasstromen en consumptie te effenen. Opleiding en toegang tot infrastructuur blijken cruciale factoren te zijn voor het verklaren van de keuze tussen agrarische en niet-agrarische activiteiten. Hoger onderwijs was de belangrijkste bepalende factor die mensen toegang gaf tot participatie in publieke of private niet-agrarische organisaties, terwijl deelname aan zelfstandige nietagrarische activiteiten slechts beroepsonderwijs of middelbaar onderwijs vereisten.

De determinanten van niet-agrarisch inkomen gegeven de deelname aan niet-agrarische activiteiten verschilden van de determinanten van deelname op zich. In het bijzonder, meer eigendom van vee verlaagt de prikkels om deel te nemen aan de LNAE als een bron van inkomen, maar had een positief effect op het inkomen van deze activiteiten gegeven deelname doordat het investering van veeinkomen in meer winstgevende niet-agrarische activiteiten mogelijk maakt. Hoger onderwijs had een positief effect op inkomen uit niet agrarische zelfstandige bedrijvigheid, maar had geen effect op deelname, aangezien deze bedrijvigheid meestal plaatsvindt in de informele sector, die geen opleiding vereist. Grotere transactiekosten veroorzaakt door afgelegenheid stimuleerden deelname aan de LNAE, maar hadden een negatief effect op niet-agrarisch inkomen.

In het vijfde hoofdstuk combineren we internationale seizoensmigratie, permanente migratie en lokale niet-agrarische activiteiten in één empirisch model. Dit maakt het mogelijk om hun determinanten te vergelijken en beter inzicht te krijgen in hun complexe relaties. De empirische resultaten laten zien dat beter opgeleide personen met meer land een grotere kans hadden om permanente migratie te verkiezen boven werken op het boerenbedrijf, terwijl beter opgeleide personen met weinig land een grotere kans hadden om lokale niet-agrarische activiteiten te verkiezen boven het boerenbedrijf. Dit geeft aan dat zowel permanente migratie als werk in de niet-agrarische sector substituten zijn van activiteiten in de landbouw en kunnen wedijveren om de best opgeleide plattelandsbewoners. Het verschil was dat de permanente migratieoptie niet toegankelijk leek voor individuen van arme huishoudens met kleine boerderijen die daarom deelnamen aan lokale niet-agrarische activiteiten, terwijl diegenen met opleiding en de hulpmiddelen om migratie te financieren ervoor kozen om het land permanent te verlaten.

De focus van hoofdstuk zes ligt op het testen van de hypotheses van de Nieuwe Arbeidsmigratie-Economie over de effecten van internationale arbeidsmigratie en overmakingen op agrarische productiviteit en gewasinkomen. We waren in het bijzonder geïnteresseerd in het uitbreiden van bestaande studies 
en het testen of de effecten van overmakingen verschillend zijn voor boeren met verschillende bedrijfsgrootten en of het effect van verloren arbeid verschillend is voor seizoens- en permanente migratie. Onze resultaten laten zien dat het verlies van productieve leden een substantieel verlies van gewasinkomen betekent, waarschijnlijk als gevolg van imperfecties in de arbeidsmarkt en het sterk leunen op familiearbeid. Het negatieve effect van verloren arbeid werd echter deels gecompenseerd door verkregen overmakingen. Dit betekent dat plattelandshuishoudens profiteerden van overmakingen, die liquiditeits- en verzekeringsbeperkingen verlichtten en de productiviteit van akkerbouw verhoogden. Het positieve effect van overmakingen verschilde echter tussen boeren met verschillende hoeveelheden land. Het marginale effect van overmakingen op gewasproductie was lager voor grotere boeren. Dit is mogelijk gerelateerd aan de afwezigheid van bindende liquiditeitsbeperkingen voor de gewasproductie van deze boeren en aan hun lage landbouwproductiviteit. Tenslotte hebben we gevonden dat alleen permanente migranten een significant negatief effect hebben op het inkomen uit akkerbouw.

De verkregen resultaten hebben belangrijke beleidsimplicaties. We hebben geconstateerd dat de RNAE in de Kirgizische republiek vooral aangedreven wordt door slechte omstandigheden voor landbouw en niet-agrarische activiteiten die toegankelijk zijn voor de armen. Dit betekent dat behalve het stimuleren van landbouwontwikkeling op zich door het oprichten van werkende instituties gericht op kleine familieboerderijen, een focus op algemene factoren die de winstgevendheid en expansie van de huidige niet-agrarische activiteiten belangrijk is, in het bijzonder in gebieden waar de capaciteit van de landbouw beperkt wordt door de natuurlijke omgeving. Investeringen in infrastructuur, toegang tot financiële hulpmiddelen, het opbouwen van vaardigheden, het vergroten van menselijk kapitaal en lokale groeimotoren kunnen helpen om de benodigde gunstige omstandigheden te creëren en moeten in acht genomen worden bij het ontwikkelen en uitvoeren van plattelandsbeleid in Kirgizstan. Speciaal beleid om de toegang van de armen tot winstgevende niet-agrarische activiteiten te verhogen is alleen nuttig in de weinige gebieden met erg gunstige landbouwomstandigheden of met vakantieoorden.

Het belang van lokale niet-agrarische activiteiten moet ook meegenomen worden door beleidsmakers omdat internationale migratie grote toegangsbarrières lijkt te hebben en niet toegankelijk lijkt te zijn voor diegenen met weinig land, tenminste in de tijdsperiode omvat door deze studie. Bovendien zijn permanente migranten vaak hoger opgeleid, wat kan leiden tot een braindrain effect. Het stimuleren van tijdelijke migratie met regelmatige bezoeken aan huis heeft daarom, vooral voor diegenen met een betere opleiding, de potentie om de negatieve effecten van migratie op lokale ontwikkeling te verminderen.

De vastgestelde positieve rol van overmakingen op de lokale landbouw moet niet overschat worden, ook al helpen overmakingen kleine boeren om 
bestaande liquiditeits- en verzekeringsbeperkingen te overwinnen. Toegenomen productiviteit als gevolg van overmakingen kan gewasinkomen alleen doen toenemen in het geval van seizoensmigratie. De toename is niet groot genoeg om het substantiële verlies van arbeid als gevolg van permanente migratie te compenseren. Bovendien hebben overmakingen geen positief effect op grote boerderijen en verlagen ze hier zelfs het gewasinkomen. Deze bevindingen geven aan dat de agrarische sector nog steeds gericht is op zelfvoorziening in plaats van op de markt georiënteerd en dat de vooruitzichten van de landbouw in de context van voortdurende arbeidsmigratie op zijn best onzeker zijn. Toch zou de schepping van een institutionele omgeving die in dienst staat van geïndividualiseerde, kleinschalige landbouw boven aan de agenda van beleidsmakers en de donorgemeenschap moeten staan. Dit zou bovendien permanente arbeidsmigratie kunnen afremmen en dus de negatieve gevolgen hiervan voor de lokale akkerbouw kunnen beperken. Een andere potentiële mogelijkheid om de ontwikkelingseffecten van migratie te verbeteren is om tijdelijke migratie met daarop volgende terugkeer te stimuleren. 


\section{CURICULLUM VITAE}

Aziz Atamanov was born in the Kyrgyz Republic in 1979. He studied Economics at International University of Kyrgyzstan and graduated with a Master's degree with honours in Economics majoring in banking in 2002. In 2004 he finished the Applied Economic Policy course at the Joint Vienna Institute with a letter of excellence. In 2006 he graduated from the Central European University obtaining a second Master's degree with distinction in Public Policy.

Having graduated from International University of Kyrgyzstan, Aziz joined the international think-tank Center for Social and Economic Research CASEKyrgyzstan as a researcher. He worked there with breaks till 2008 and combined research activities with teaching of introductory econometrics at Russian Slavic University in Bishkek.

During his work at CASE-Kyrgyzstan, Aziz participated in numerous research and consultancy projects working on various problems of the Kyrgyz economy including fiscal and social policy, international trade and foreign aid, international labour migration and remittances. He was also involved into independent evaluation of various projects of UNICEF, UNDP, and Swiss Development Cooperation working in Kyrgyzstan, Uzbekistan and Tajikistan.

Aziz started the pursuit of his $\mathrm{PhD}$ in September 2008 with a research project focused on the determinants and effects of rural nonfarm activities and international labour migration in the Kyrgyz Republic. 


\section{MGSOG DISSERTATION SERIES}

Frieda Vandeninden

Poverty Alleviation: Aid and Social Pensions

MGSoG Dissertation Series, nr 22 (2011)

Juliana Nyasha Tirivayi

The Welfare Effects of Integrating AIDS Treatment with Food Transfers:

Evidence from Zambia

MGSoG Dissertation Series, nr 21 (2011)

Agnieszka Ewa Sowa

Who's Left Behind? Social Dimensions of Health Transition and Utilization of Medical

Care in Poland

MGSoG Dissertation Series, nr 20 (2011)

Emmanaouil Sfakianakis

The Role of Private Actors in the Provision of Public Goods with Applications to Infrastructure and Financial Stability

MGSoG Dissertation Series, nr 19 (2011)

Siu Hing Lo

White Collars Green Sleeves:

An Interorganizational Comparison of Determinants of Energy-Related Behaviors among Office Workers

MGSoG Dissertation Series, nr 18 (2011)

Treena $\mathrm{Wu}$

Constraints to Human Capital Investment in Developing Countries:

Using the Asian Financial Crisis in Indonesia as a Natural Experiment

MGSoG Dissertation Series, nr 17 (2011)

Henry Espinoza Peña

Impact Evaluation of a Job-Training Programme for Disadvantaged Youths:

The Case of Projoven

MGSoG Dissertation Series, nr 16 (2011)

Florian Tomini

Between Family and Friends

Understanding the Interdependency of Private Transfers

MGSoG Dissertation Series, nr 15 (2010) 
Michał Polalowski

The Institutional Transformation of Social Policy in East Central Europe:

Poland and Hungary in comparative and historical perspective

MGSoG Dissertation Series, nr 14 (2010)

Maha Ahmed

Defining, Measuring and Addressing Vulnerability:

The Case of Post Conflict Environments

MGSoG Dissertation Series, nr 13 (2010)

Pascal Beckers

Local Space and Economic Success

The role of spatial segregation of migrants in the Netherlands

MGSoG Dissertation Series, nr 12 (2011)

Victor Cebotari

Conflicting Demands in Ethnically Diverse Societies

Ethnopolitical Contention and Identity Values in Europe

MGSoG Dissertation Series, nr 11 (2010)

Dennis Gyllensporre

Competing and Complementary Perspectives on the EU as a Crisis Management Actor:

An Examination of the Common Security and Defence Policy through the Lenses of

Idealism and Realism

MGSoG Dissertation Series, nr 10 (2010)

Judit Vall Castello

Business Cycle and Policy Effects on Labour Market Transitions of Older and Disabled

Workers in Spain

MGSoG Dissertation Series, nr. 9 (2010)

Keetie Roelen

False Positives or Hidden Dimensions: the definition and measurement of child poverty

MGSoG Dissertation Series, nr. 8 (2010)

Denisa Maria Sologon

Earning Dynamics in Europe

MGSoG Dissertation Series, nr. 7 (2010)

Melissa Siegel

Money and Mobility: Migration and Remittances 
MGSoG Dissertation Series, nr. 6 (2010)

Jessica S. Hagen-Zanker

Modest Expectations: Causes and effects of migration on migrant households in source countries

MGSoG Dissertation Series, nr. 5 (2010)

Mirtha R. Muniz Castillo

Human Development and Autonomy in Project Aid: Experiences from four bilateral projects in Nicaragua and El Salvador

MGSoG Dissertation Series, nr. 4 (2009)

Christiane Arndt

Governance Indicators

MGSoG Dissertation Series, nr. 3 (2009)

Britta Augsburg

Microfinance - Greater Good or Lesser Evil?

MGSoG Dissertation Series, nr. 2 (2009)

Geranda Notten

Measuring and Managing Poverty Risks

MGSoG Dissertation Series, nr. 1 (2008) 